UNIVERSIDADE DE SÃO PAULO

FACULDADE DE FILOSOFIA, LETRAS E CIÊNCIAS HUMANAS

DEPARTAMENTO DE LETRAS CLÁSSICAS E VERNÁCULAS

PROGRAMA DE PÓS-GRADUAÇÃO EM ESTUDOS COMPARADOS DE

LITERATURAS DE LÍNGUA PORTUGUESA

MÁRCIO AURÉLIO RECCHIA

Portugal, um país "neutro" perante a guerra: a desconstrução da propaganda salazarista em Fantasia Lusitana

(VERSÃO CORRIGIDA)

São Paulo 


\title{
Portugal, um país "neutro" perante à guerra: a desconstrução da propaganda salazarista em Fantasia Lusitana (VERSÃO CORRIGIDA)
}

\author{
Dissertação apresentada ao Programa de Pós- \\ graduação em Estudos Comparados de Literaturas \\ de Língua Portuguesa, do Departamento de Letras \\ Clássicas e Vernáculas da Faculdade de Filosofia, \\ Letras e Ciências Humanas da Universidade de São \\ Paulo, como parte dos requisitos para obtenção do \\ título de Mestre em Letras. \\ Área de concentração: Estudos Comparados de \\ Literaturas de Língua Portuguesa \\ Orientadora: Prof ${ }^{a}$. Dr ${ }^{\mathrm{a}}$. Aparecida de Fátima Bueno
}

São Paulo 
Autorizo a reprodução e divulgação total ou parcial deste trabalho, por qualquer meio convencional ou eletrônico, para fins de estudo e pesquisa, desde que citada a fonte.

Catalogação na Publicação

Serviço de Biblioteca e Documentação

Faculdade de Filosofia, Letras e Ciências Humanas da Universidade de São Paulo

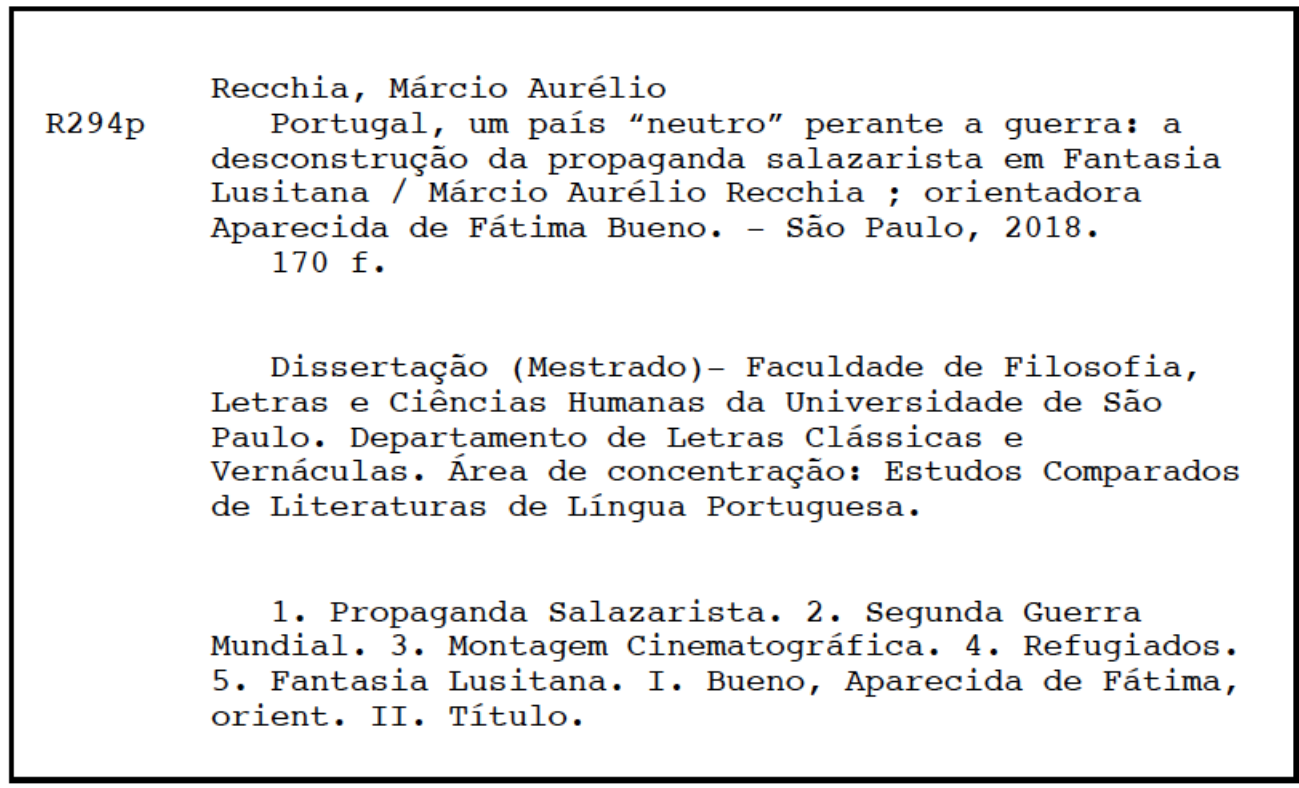


RECCHIA, Márcio Aurélio. Portugal, um país "neutro" perante a guerra: a desconstrução da propaganda salazarista em Fantasia Lusitana.

Dissertação apresentada ao Programa de Pósgraduação em Estudos Comparados de Literaturas de Língua Portuguesa, do Departamento de Letras Clássicas e Vernáculas da Faculdade de Filosofia, Letras e Ciências Humanas da Universidade de São Paulo, como parte dos requisitos para obtenção do título de Mestre em Letras.

Aprovado em:

Banca Examinadora

Prof. Dr. Instituição

Julgamento Assinatura

Prof. Dr. Instituição

Julgamento Assinatura

Prof. Dr. Instituição

Julgamento Assinatura

Prof. Dr. Instituição Assinatura 
Dedico este trabalho à memória dos meus avós Achilles e Ernestina Recchia e Cristino e Odila Faria, pelo amor que me dedicaram e pelo exemplo de vida que foram para mim. 


\section{AGRADECIMENTOS}

À professora Aparecida de Fátima Bueno, por me acolher como orientando e por me guiar durante os anos de pesquisa no mestrado. Obrigado pela paciência, disponibilidade e incentivo perante os desafios e por todos os ensinamentos.

À professora Carolin Overhoff Ferreira, pela participação em minha banca de qualificação e por ter aceitado integrar a minha banca de defesa. Agradeço as indicações de leitura que auxiliaram bastante no desenvolvimento de minha pesquisa.

Às professoras Fabiana Carelli e Mariana Duccini, que, juntamente com a professora Carolin, gentilmente aceitaram fazer parte da minha banca de defesa e contribuíram com recomendações e conselhos.

À professora Marcia Valeria Zamboni Gobbi, pela participação em minha banca de qualificação, pelas indicações de leitura e sugestões.

Ao professor Pedro Schacht Pereira, que muito tem contribuído em prol do debate atual acerca do colonialismo português e da desconstrução de sua imagem fantasiosa.

A todos os professores do Programa de Estudos Comparados de Literaturas de Língua Portuguesa que colaboraram com leituras valiosas.

À professora Maria do Rosário Lupi Bello, cujo curso sobre literatura, cinema e dramaturgia foi fundamental para a minha compreensão sobre a análise da narrativa fílmica, elemento bastante significativo para o amadurecimento da minha pesquisa.

À professora Renata S. Junqueira pelo carinho com que me acolheu no Grupo de Pesquisas em Dramaturgia e Cinema, e a todos os seus integrantes, em especial ao Professor Pedro M. Guimarães pelas sugestões e contribuições em minha pesquisa.

Aos professores e pesquisadores envolvidos com o Cinema Português, pelas contribuições, indicações de leitura, críticas e sugestões, especialmente a Daniel Ribas, Jorge Cruz, Leandro Mendonça, Lisa Vasconcellos, Mariana Copertino e Paulo Cunha.

À Tania Antonietti Lopes, pela disponibilidade em ajudar, pela contribuição com sugestões de leituras e com o empréstimo de títulos literários importantes.

A todos os colegas do Grupo de Pesquisa Colonialismo e Pós-Colonialismo em Português, pelo aprendizado em conjunto, pela troca de experiências e pelas conversas, 
acadêmicas ou não, em especial à Alex Neiva, Carla Kinzo, Carolina Medeiros, Elizabeth Ferreira, Johin Sueny, Paula Fábrio, Pedro Proença, Renata Carvalho e Viviana Antunes.

Ao Centro de Estudos das Literaturas e Culturas de Língua Portuguesa (CELP), em especial à Marinês Mendes, pelo suporte e disponibilidade durante o mestrado.

À amiga Edimara Lisbôa, que sempre me incentivou ao estudo do Cinema Português, apresentando diversos filmes e vasta bibliografia. Pelo prestimoso auxílio nas várias fases da minha pesquisa e escrita e pela imediata disposição em ajudar.

À amiga Penélope Salles, que me acompanhou de perto nesse retorno ao mundo acadêmico. Pelo companheirismo, ajuda, incentivo, conselhos e pelas várias conversas que tivemos no decorrer do mestrado, que contribuíram para o nosso amadurecimento.

Ao amigo José Vanzelli, pelas recomendações e sugestões acadêmicas. Obrigado pelo companheirismo, pelo apoio, pelos valorosos conselhos e pela grata interlocução.

Ao amigo Fabrizio Maeda, pelas sugestões, trocas de ideias, pelo suporte e por todo aprendizado proporcionado.

Ao Antônio Bernardo Araújo Júnior, cuja oportuna ajuda na fase final do mestrado foi essencial para que eu conseguisse concentrar esforços.

Ao amigo e irmão Lúcio Franchi Cruz, que sempre esteve ao meu lado me apoiando em várias fases da minha vida. Obrigado pelos conselhos, pelo incentivo de sempre, e pela prestimosa ajuda com a organização do meu texto.

Ao Elton Sousa Moura, pelas pertinentes dicas sobre mapas mentais e o processo de escrita, e pelo apoio de sempre.

Aos meus pais Aurelio e Célia, que sempre acreditaram em mim, pela educação proporcionada e pelo apoio irrestrito, sem os quais nada seria possível.

À minha irmã Mara, meu cunhado Jailton e meus sobrinhos Stephanie e Victor, pelos anos de convivência, pelo carinho, dedicação e toda ajuda dispensada.

À minha irmã Maíra e meu cunhado Robson, pelo apoio incondicional e pelo carinho, e em especial à minha sobrinha Antonella, que tanto alegra a minha vida.

Enfim, agradeço a todos que, de alguma forma, me apoiaram e incentivaram durante esses anos de leituras, estudos e pesquisas acadêmicas no mestrado. 
Sobre a nudez forte da verdade - o manto diáfano da fantasia

(QUEIRÓS, Eça de, 1997)

Sobre a nudez forte da verdade o manto diáfano da fantasia, parece clara a sentença, clara, fechada e conclusa, uma criança será capaz de perceber e ir ao exame repetir sem se enganar, mas essa mesma criança perceberia e repetiria com igual convicção um novo dito, Sobre a nudez forte da fantasia o manto diáfano da verdade, e este dito, sim, dá muito mais que pensar, e saborosamente imaginar, sólida e nua a fantasia, diáfana apenas a verdade

(SARAMAGO, José, 1994)

Il modo migliore per difendersi dall'invasione di memorie pesanti è impedirne l'ingresso, stendere una barriera sanitaria lungo il confine. È piú facile vietare l'ingresso a um ricordo che liberarsene dopo che è stato registrato

(LEVI, Primo, 2017) 


\section{RESUMO}

RECCHIA, Márcio Aurélio. Portugal, um país "neutro" perante a guerra: a desconstrução da propaganda salazarista em Fantasia Lusitana. São Paulo, 2018. 170 f. Dissertação (Mestrado em Letras) - Faculdade de Filosofia, Letras e Ciências Humanas, Universidade de São Paulo.

António de Oliveira Salazar foi a figura central do Estado Novo português (1933-1974), responsável pelo estabelecimento de um governo antidemocrático, autoritário, que fez uso da censura, promoveu a tortura, e criou órgãos que disseminavam os valores do regime, tais como o SPN (Secretariado da Propaganda Nacional). Podemos dizer que a atuação da propaganda foi tão eficiente durante os longos anos de ditadura que não é incomum, nos dias atuais, encontrar parcelas da população portuguesa que reproduzem vários mitos criados ou disseminados durante o governo de Salazar, chegando mesmo a enaltecer a figura do ditador. Para uma melhor compreensão desse contexto, nosso objetivo é analisar o documentário Fantasia Lusitana (2010), de João Canijo (Porto, 1957), pois nele o realizador desconstrói a propaganda salazarista, produzida, sobretudo, durante o período da Segunda Guerra Mundial (1939-1945). Composto exclusivamente por material de arquivo, o documentário conjuga excertos de filmes, noticiários, canções, fotografias, documentos, jornais e revistas, produzidos ou chancelados pela SPAC (Sociedade Portuguesa de Actualidades Cinematográficas), bem como material de fontes independentes ou externas, portanto, não submetido ao crivo da censura. Neste segundo bloco, destacamos o registro fotográfico de refugiados estrangeiros que utilizaram Lisboa como rota de fuga da perseguição nazista, uma vez que Portugal havia adotado o status de neutralidade durante a guerra. Entretanto, o contraponto ao discurso oficial promovido pelo governo ditatorial se dá principalmente através das anotações de Alfred Döblin, Erika Mann e Antoine de Saint-Exupéry, três intelectuais famosos que, por meio de um olhar crítico e isento da influência da propaganda, registraram suas impressões sobre o Portugal salazarista enquanto fugiam da guerra. $\mathrm{O}$ contraste entre essas duas realidades se dá, sobretudo, por meio da criteriosa montagem em Fantasia Lusitana, capaz de transportar o espectador, muitas vezes de forma inesperada, tanto para o fantasioso mundo português criado pela propaganda estatal, quanto para a dura realidade imposta às vítimas e aos refugiados da guerra.

Palavras-chave: Propaganda Salazarista; Segunda Guerra Mundial; Montagem Cinematográfica; Refugiados; Fantasia Lusitana. 


\begin{abstract}
RECCHIA, Márcio Aurélio. Portugal, a "neutral" country facing the war: the deconstruction of the salazarist propaganda in Fantasia Lusitana. São Paulo, 2018. $170 \mathrm{f}$. Dissertação (Mestrado em Letras) - Faculdade de Filosofia, Letras e Ciências Humanas, Universidade de São Paulo.

António de Oliveira Salazar was the central figure of the Portuguese Estado Novo (19331974), being responsible for the establishment of an antidemocratic, authoritarian government which used censorship, promoted torture, and created organs that disseminated the values of the regime, such as the SPN (Secretariado da Propaganda Nacional). We can say that the role of the propaganda was so efficient during the long years of dictatorship that nowadays it is not uncommon to find segments of the Portuguese population that reproduce various myths created or disseminated during Salazar's government, even exalting the figure of the dictator. For a better understanding of this context, our aim is to analyze the documentary Fantasia Lusitana (2010), by João Canijo (Oporto, 1957), whereupon the movie director deconstructs the Salazarist propaganda, which was produced especially during the period of World War II (1939-1945). Composed exclusively of material from archives, the documentary combines excerpts from films, news, songs, photographs, documents, newspapers and magazines, produced or endorsed by the SPAC (Sociedade Portuguesa de Actualidades Cinematográficas), as well as material from independent or external sources, therefore, not subjected to censorship. In this second group, we highlight the photographic record of foreign refugees who used Lisbon as an escape route from the Nazi persecution, since Portugal had adopted the status of neutrality during the war. However, the counterpoint to the official discourse promoted by the dictatorial government comes mainly from the memoirs written by Alfred Döblin, Erika Mann and Antoine de Saint-Exupéry, three famous intellectuals who, through a critical view and, free from the influence of the propaganda, recorded their impressions on Salazarist Portugal while they fled from the war. The contrast between these two realities comes mainly through the careful editing in Fantasia Lusitana, capable of transporting the spectator, often unexpectedly, both to the fanciful Portuguese world created by the State propaganda and to the harsh reality imposed on the war victims and refugees.
\end{abstract}

Keywords: Salazarist propaganda; World War II; Film Editing; Refugees; Fantasia Lusitana. 


\section{SUMÁRIO}

INTRODUÇÃO ........................................................................................................... 12

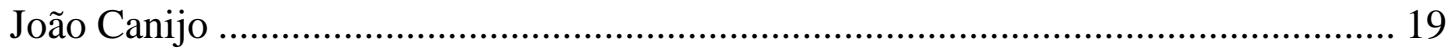

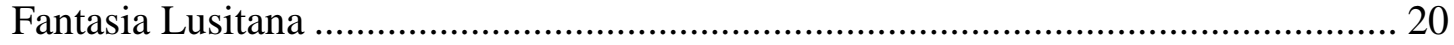

CAPÍTULO 1: O MUNDO DA FANTASIA .............................................................. 27

1.1 Com a palavra, António de Oliveira Salazar ........................................................ 27

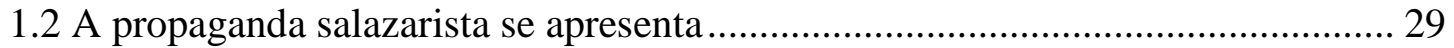

1.3 Os discursos de Salazar, ou “a voz de Deus"......................................................... 34

$1.4 \mathrm{O}$ desvario de uma nação fechada em si mesma................................................. 38

$1.5 \mathrm{O}$ recrudescimento da guerra assombra Portugal................................................ 43

1.6 A "neutralidade" e a "diplomacia” portuguesas ................................................. 47

CAPÍTULO 2: A CONTESTAÇÃO DA FANTASIA................................................ 53

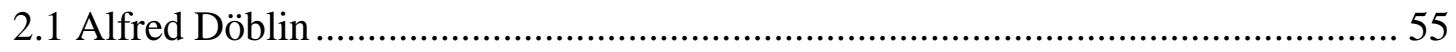

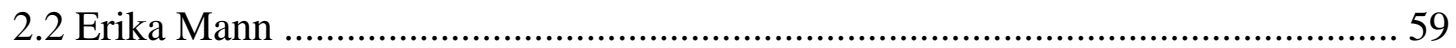

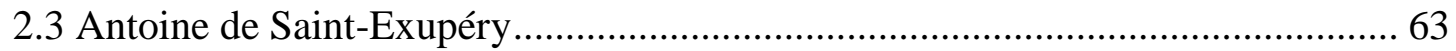

CAPÍTULO 3: A ALTERNÂNCIA DAS CAMADAS.................................................. 70

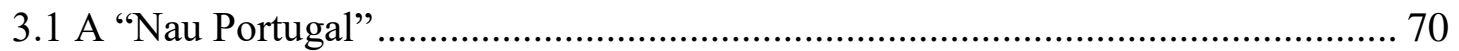

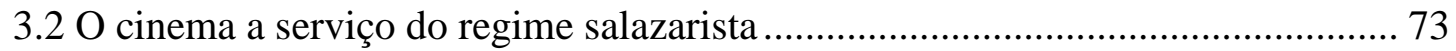

3.3 A Exposição do Mundo Português ......................................................................... 84

CAPÍTULO 4: A DESCONSTRUÇÃO DA FANTASIA .......................................... 95

4.1 As imagens escolhidas para corroborar as falas estrangeiras ............................. 97

4.2 A ridicularização dos discursos de Salazar ....................................................... 102

4.3 As fotografias utilizadas em Fantasia Lusitana ................................................ 109

4.3.1 O olhar por trás das fotografias de rostos.................................................. 115

4.3.2 A câmera que direciona o olhar do espectador ........................................... 120

CAPÍTULO 5: A ASTÚCIA DO REGIME SALAZARISTA.................................. 128

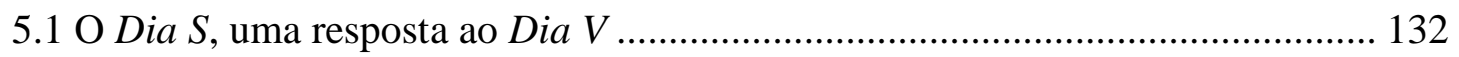

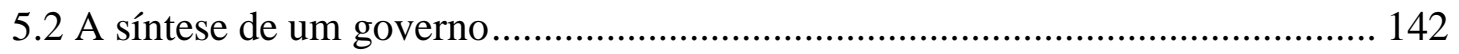

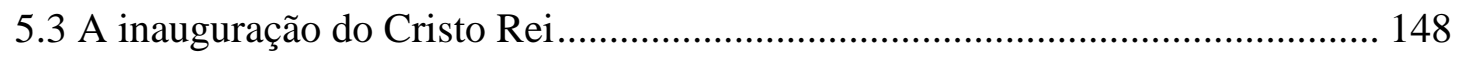

CONCLUSÃO

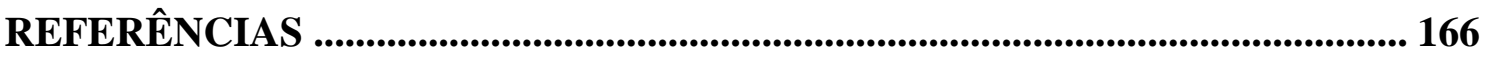

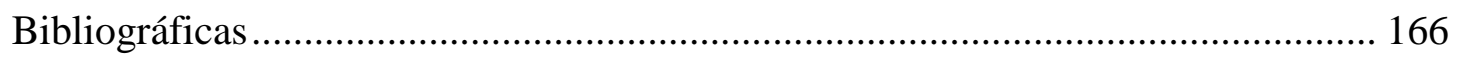

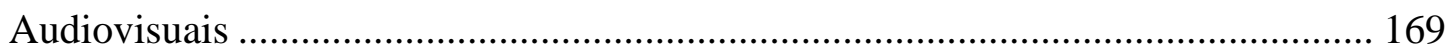

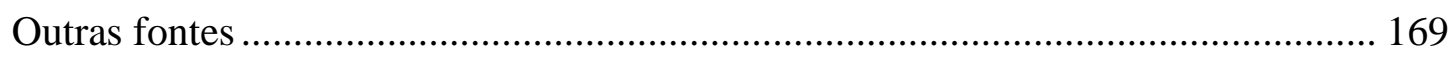




\section{INTRODUÇÃO}

O Estado Novo português, com seu regime autoritário, foi um dos mais longevos do século XX na Europa, contando com quase meio século de duração. Gestado com o golpe de 28 de maio de 1926, que pôs fim à Primeira República, teria o início de sua consolidação com a constituição de 1933, sobrevivendo ao pós-guerra, e vindo a colapsar apenas em 1974. António de Oliveira Salazar (1889-1970) é a figura de maior expoente nesse período, tendo ocupado os cargos de Ministro das Finanças, Ministro dos Negócios Estrangeiros, Ministro da Defesa, Presidente da República interino, mas sua figura está fortemente associada à função de Presidente do Conselho de Ministros, ou seja, detentor do poder executivo. Afastado do comando do governo em 1968 após sofrer um acidente doméstico, veio a falecer em 1970, aos 81 anos. Seu sucessor foi Marcello Caetano (19061980), cujo governo manteve-se alinhado à ideologia de Salazar, sendo deposto com a Revolução dos Cravos.

Com o início da democratização após o 25 de abril, iniciou-se uma época de abertura em que vários intelectuais puderam finalmente se expressar acerca da ditadura salazarista sem o risco de serem censurados ou perseguidos. $\mathrm{Na}$ década seguinte, inúmeras obras literárias que revisitam criticamente a história de Portugal do século XX foram publicadas, com destaque para o romance $O$ ano da morte de Ricardo Reis (1984), de José Saramago, cujo enredo se desenvolve prevalentemente em 1936, em pleno período de alicerçamento do Estado Novo.

Embora não seja o seu escopo principal, esse romance examina, de forma irônica, mas criteriosa, os meandros por trás da máquina estatal daquele período, revelando a forma como os meios de comunicação de massa foram controlados pelos órgãos governamentais e utilizados para influenciar a população. Os jornais, a rádio, o teatro, o cinema, o mercado editorial, em suma, não apenas a mídia, mas também o aparato cultural, sofreram censura e foram utilizados em prol do regime, como bem revelam o narrador e alguns personagens deste romance.

A respeito do emprego dos jornais no governo de Salazar, trazemos um excerto do romance que revela a maneira como este meio de comunicação impresso não poupava encômios para com a figura do ditador e de sua administração. Trata-se de um momento 
em que o personagem Ricardo Reis, hóspede do Hotel Bragança, faz as leituras das gazetas matinais. $\mathrm{O}$ narrador faz um resumo do tipo de notícias veiculadas à época:

Dizem também os jornais, de cá, que uma grande parte do país tem colhido os melhores e mais abundantes frutos de uma administração e ordem pública modelares, e se tal declaração for tomada como vitupério, uma vez que se trata de elogio em boca própria, leia-se aquele jornal de Genebra, Suíça, que longamente discorre, e em francês, o que maior autoridade lhe confere, sobre o ditador de Portugal, [...] chamando-nos de afortunadíssimos por termos no poder um sábio (SARAMAGO, 1994, p. 86).

Tanto a imprensa nacional quanto a internacional publicavam matérias que exaltavam o regime e seu líder, o que lhes poderia conferir um aspecto de imparcialidade. Contudo, em um diálogo entre os personagens Ricardo Reis e Fernando Pessoa acerca do que os jornais escreviam sobre o governante na Nação, o primeiro comenta com o segundo:

[...] voltando ao Salazar, quem diz muito bem dele é a imprensa estrangeira, Ora, são artigos encomendados pela propaganda, pagos com o dinheiro do contribuinte, lembro-me de ouvir dizer, Mas olhe que a imprensa de cá também se derrete em louvações, pega-se num jornal e fica-se logo a saber que este povo português é o mais próspero e feliz da terra, ou está para muito breve, e que as outras nações só terão a ganhar se aprenderem connosco, $\mathrm{O}$ vento sopra desse lado, Pelo que lhe estou a ouvir, você não acredita muito nos jornais (SARAMAGO, 1994, p. 279).

Referentemente ao teatro, $O$ ano da morte de Ricardo Reis traz uma passagem em que o protagonista vai assistir Tá-Mar, peça de Alfredo Cortez que aborda a vida e os costumes de pescadores da vila de Nazaré, distante cerca de 130 quilômetros de Lisboa. Enquanto adquire o ingresso para o espetáculo, Ricardo Reis fica sabendo pelo bilheteiro que os legítimos pescadores daquela localidade estariam presentes naquela sessão. $\mathrm{O}$ narrador informa que os trabalhadores da pesca "entravam e ocupavam os seus lugares nos camarotes de segunda ordem, ficavam de palanque para verem bem e serem vistos, vestidos à sua moda, eles e elas, se calhar descalços" (SARAMAGO, 1994, p. 109).

Ao final do espetáculo, os aplausos são dirigidos aos atores, que os redirecionam aos verdadeiros homenageados, ou seja, os pescadores que ali se encontravam. Eles então deixam os seus lugares e se dirigem "ao palco, ali dançam e cantam as modas tradicionais da sua terra, no meio dos artistas, esta noite irá ficar nos anais da Casa de Garrett" (SARAMAGO, 1994, p. 113).

Dessa forma, a mise en scène proposta além da montagem teatral, coloca de baixo do mesmo teto representantes das várias camadas sociais, ou seja, a classe mais abastada, que tinha condições de frequentar as artes, os artistas e a classe mais pobre, representada 
pelos pescadores. Ao final do espetáculo, todos celebram o elemento que têm em comum, isto é, o fato de serem portugueses. Esta prática fazia parte da propaganda salazarista com o intuito de gerar um sentimento de pertencimento a um grupo, ou seja, uma identidade nacional. Entretanto, é no dia seguinte, quando os pescadores estão prestes a voltar para Nazaré, que a "espontaneidade da celebração da portugalidade" é revelada:

[...] à partida da camioneta, com assistência de jornalistas, fotógrafos e dirigentes corporativos, os pescadores levantarão vivas ao Estado Novo e à Pátria, não se sabe de ciência segura se por contrato o tinham de fazer, admitamos que foi expressão de corações agradecidos por lhes ter sido prometido o desejado porto de abrigo (SARAMAGO, 1994, p. 113).

O narrador, de forma incisiva, revela a presença "de jornalistas, fotógrafos e dirigentes corporativos" na despedida dos pescadores. Era necessário registrar aquele momento e divulgá-lo nos meios de comunicação, pois fazia parte da propaganda. Além disso, a instância narrativa levanta a possibilidade de haver um contrato para que os pescadores dessem "vivas ao Estado Novo", fato plausível e coerente diante dos valores do regime que exaltavam os elementos pitorescos e únicos de Portugal, baseados em uma construção ideológica.

Concernente ao papel do cinema explorado pelo romance, destacamos o episódio das gravações do filme A Revolução de Maio (1937), de António Lopes Ribeiro, que acontecem durante o tempo diegético e conta com a atuação do personagem Victor, membro da Polícia de Vigilância e Defesa do Estado, em uma cena de investigação criminal. O narrador critica o argumento dessa película pelo fato de Lopes Ribeiro fazer uso de uma fórmula recorrente e mediana, isto é, eleger uma figura feminina (Maria Clara) como a responsável pela conversão de um revolucionário bolchevista (Manuel Fernandes, pseudônimo de César) em apoiador do Estado Novo.

De fato, este filme patenteia de que forma o cinema sob o governo de Salazar estava a serviço do regime. A respeito dessa obra de Lopes Ribeiro, Luís Reis Torgal afirma que

Trata-se, pois, de uma película com todas as características de «filme oficial»: patrocinado pelo SPN, teve ainda os «valiosos auxílios» da Presidência do Ministério, dos Ministérios dos Negócios Estrangeiros, do Interior, da Agricultura, da Marinha e da Guerra, da União Nacional e da Polícia Internacional Portuguesa. Trata-se do «primeiro grande filme de exaltação nacionalista», no dizer de um cartaz de publicidade (TORGAL, 2011, p. 74).

Buscamos trazer apenas alguns exemplos de como o romance $O$ ano da morte de Ricardo Reis, publicado dez anos após a Revolução de abril, desconstrói a propaganda 
salazarista, utilizando-se da ironia e da reflexão crítica. Se neste romance Saramago denuncia o modo como a imprensa, as artes e os meios de comunicação em geral serviram para propagar a ideologia salazarista, será apenas no documentário Fantasia Lusitana (2010), de João Canijo, que as estratégias utilizadas pela propaganda do regime serão esmiuçadas, o que talvez ajude a compreender a sua longevidade.

A passagem do século XIX para o século XX viu o desenvolvimento da indústria cinematográfica, sobretudo como ferramenta de grande abrangência popular. Pouco tempo mais tarde, esse alcance viria a ser expandido com o avanço e a popularização da radiodifusão. Mais do que simplesmente entreter ou informar, esses meios de comunicação seriam as principais formas de acesso à população, especialmente se considerarmos os altos índices de analfabetismo presentes em Portugal na primeira metade do século passado. A esse respeito, transcrevemos o trecho de um programa britânico que aborda a questão da educação portuguesa, recuperado das legendas de Fantasia Lusitana:

\footnotetext{
O novo Portugal ensina o seu povo, mas pouco. $70 \%$ dos Portugueses são analfabetos. E maioritariamente as novas escolas são pré-escolares e de ensino primário. Ensinam-se as crianças a ter orgulho na nação e no seu grande passado através de meios, como, uma aldeia que reproduz em miniaturas construções históricas portuguesas (FANTASIA LUSITANA, 2010, 41:54 $42: 15)$.
}

No excerto acima, vemos tanto a questão da baixa escolaridade existente nos anos iniciais do Estado Novo, quanto a influência que ele exercia na educação infantil, principalmente no tocante à carga ideológica ensinada às crianças. Assim, gostaríamos de refletir de que forma governos antidemocráticos atuam não apenas na educação, mas nos diversos setores da sociedade. Segundo a historiadora Maria Helena Rolim Capelato,

Em qualquer regime, a propaganda política é estratégia para o exercício do
poder, mas nos de tendência totalitária ela adquire uma força muito maior
porque o Estado, graças ao monopólio dos meios de comunicação, exerce
censura rigorosa sobre o conjunto das informações e as manipula. O poder
político, nesses casos, conjuga o monopólio da força física e simbólica. Tenta
suprimir, dos imaginários sociais, toda representação do passado, presente e
futuro coletivos, distintos dos que atestam sua legitimidade e caucionam seu
controle sobre o conjunto da vida coletiva (CAPELATO, 2009, p. 76).

Capelato destaca que a propaganda política se torna uma ferramenta contumaz, principalmente em regimes que controlam os meios de comunicação, que era o caso da ditadura salazarista. A constituição de 1933, aquela que instituiu o Estado Novo, criou os modos para censurar tudo que fosse contrário aos interesses do governo. A esse respeito, Luís Reis Torgal explica que 
A legislação produzida no próprio ano da Constituição, ou até no próprio dia, e nos dias e anos seguintes, mostra que, na verdade, se pretendia tudo vigiar em defesa dessa "ordem nacional", criando-se - por vezes sob a capa de simples regulamentação de direitos dos cidadãos, considerados no citado artigo $8^{\circ}$ da Constituição - os elementos legais necessários para funcionar uma ação repressiva, que sempre fazia passar por uma ação legal, legítima e benévola (TORGAL, 2010, p. 112).

A criação de leis repressivas, muito embora justificadas como benéficas ao povo, consolidou a reintrodução da censura em Portugal. Referentemente a esse assunto, Torgal irá dizer que o regime salazarista

considerava a manutenção da censura prévia às publicações periódicas, bem como às "folhas volantes, folhetos, cartazes e outras publicações, sempre que em qualquer delas se versem assuntos de carácter público ou social" (artigo $2^{\circ}$ ). A justificação dessa censura, expressa no artigo $3^{\circ}$, deixa-nos antever com clareza a forma como ela se exercia, "a bem da Nação" e contra todas as formas de oposição, em favor da "verdade" e contra a "mentira": "A censura terá somente por fim impedir a perversão da opinião pública em sua função de força social e deverá ser exercida por forma a defendê-la de todos os factores que a desorientem contra a verdade, a justiça, a moral a boa administração e o bem comum, e a evitar que sejam atacados os princípios fundamentais da organização da sociedade" (TORGAL, 2010, p. 112-113).

Dentro deste contexto, instituições governamentais com o objetivo de salvaguardarem e promoverem os valores do regime foram criadas, como por exemplo o Secretariado da Propaganda Nacional (SPN), cujo diretor foi António Ferro. De acordo com Francisco Carlos Palomanes Martinho,

O SPN coordenou e alimentou a imprensa do regime, dirigiu os serviços de censura, organizou as encenações de massas que eram transportadas para a capital e alimentou as festividades viradas para as classes populares em estreita associação com o aparelho corporativo. Além disso, coordenou uma série de outras atividades destinadas às elites e ampliou significativamente as relações culturais com outros países (MARTINHO, 2007, p. 24).

Martinho também lembra que o projeto cultural do governo de Salazar investiu, entre outras coisas, na "promoção do cinema que, com clara vocação popular, valorizava os 'sadios valores da honestidade cristã e da família pobre, mas honrada"” (MARTINHO, 2007, p. 24).

Segundo o historiador Fernando Rosas,

O SPN vai constituir-se, assim, como o espaço por excelência da mise en scéne da política e da ideologia do regime, da sua estetização e divulgação massiva, através de um impressionante e tentacular aparelho de agitação que, em poucos anos, actuava sobre as artes plásticas [...], apostava a fundo nos novos veículos da moderna propaganda - o cinema, a rádio, o cartaz — , promovia prémios literários, lançava o «teatro do povo», reinventava a etnografia e a cultura «populares», criava um turismo oficial como decorrência destas, encenava «festas populares», «cortejos históricos» e o geral das grandes mobilizações do regime (ROSAS, 2001 p. 1.043). 
Em suma, o SPN teve atuação inquestionável na formação das massas através do controle dos meios de comunicação e da censura. Contudo, gostaríamos de nos concentrar no papel exercido pelo cinema dentro de um regime ditatorial, como foi o salazarista.

De modo geral, os estados autoritários do início do século XX se apropriaram do cinema para difundir e propagar suas ideias. Wagner Pinheiro Pereira, em sua tese de doutorado, “O Império das Imagens de Hitler - o projeto de expansão internacional do modelo de cinema nazi-fascista na Europa e na América Latina (1933-1955)”, na qual analisa filmes políticos de cunho nacionalista, aborda de que forma o cinema foi utilizado como instrumento propagandístico atingindo as massas. A princípio, ele explica que

O cinema desde sua invenção serviu inicialmente à ciência como um instrumento do seu progresso; os Exércitos também o utilizaram desde o início, até para melhor identificar as armas do inimigo. Os governos, desde muito cedo, perceberam o seu poder de propaganda e que, sob a aparência de representação, eles doutrinam e glorificam (PEREIRA, 2008, p. 18).

No que concerne ao uso do cinema pelos governos, Pereira destaca que,

Dentre todos os meios de comunicação utilizados para exercer tal influência psicológica, o cinema foi privilegiado. Neste sentido, a escolha de filmes ficcionais, de reconstituição histórica, documentários e cinejornais - como fonte primária de investigação é decorrente da importância adquirida pela produção cinematográfica com sentido político, principalmente, a partir da Primeira Guerra Mundial (PEREIRA, 2008, p. 17).

Não há dúvida da importância de se analisar o vasto material produzido com sentido político. A esse respeito, Marc Ferro afirma que o filme em si pode ser interpretado

[...] como um produto, uma imagem-objeto, cujas significações não são somente cinematográficas. Ele não vale somente por aquilo que testemunha, mas também pela abordagem sócio-histórica que autoriza. A análise não incide necessariamente sobre a obra em sua totalidade: ela pode se apoiar sobre extratos, pesquisar "séries", compor conjuntos. E a crítica também não se limita ao filme, ela se integra ao mundo que o rodeia e com o qual se comunica, necessariamente (FERRO, 1992, p.87, grifo nosso).

Numa linha próxima a Ferro, Torgal também destaca que pode-se depreender o cinema como um produto, isto é, um documento que serve à História e que sempre tem um propósito:

O cinema, se pode ser entendido, portanto, como «documento histórico» ou «fonte histórica», tem de ser considerado igualmente, conforme dizíamos, como «agente da história». Na verdade, o filme tem sempre uma intenção. Por vezes, é manifesto um objectivo de propaganda directa, ou seja, pretende produzir a «sua história», uma «história institucional» (TORGAL, 2011, p.16, grifos nossos).

No entanto, se o pesquisador 
[...] não «desconstruir» a imagem, não a procurar descrever e interpretar criticamente, ela é tão-só «uma imagem» e não uma fonte de história que, como todas as outras fontes, precisa de ser objecto de um estudo atento, com algumas ou muitas palavras ou ideias (TORGAL, 2011, p. 16, grifos nossos).

Levando-se em conta a importância da análise de material fílmico produzido com fins propagandísticos é que se elegeu Fantasia Lusitana como objeto de investigação e análise no presente estudo. Afinal, o documentário de João Canijo é elaborado apenas com material de arquivo, sobretudo gerado durante o regime salazarista e com intenção de difundir a ideologia do Estado Novo. Contudo, através da montagem, Canijo procura fazer o processo inverso, isto é, o de desconstruir a ideologia salazarista, conforme pretendemos demonstrar nesta dissertação.

Uma vez que Fantasia Lusitana recupera material de repositório de jornais cinematográficos de atualidades dos anos trinta e quarenta do século XX, é importante ter em conta que, tanto esse corpus, quanto a montagem proposta por Canijo, têm em comum o fato de possuírem um objetivo, portanto, de transmitirem uma ideia por trás das imagens que parecem ser objetivas. O crítico de cinema Guy Gauthier lembra que,

Apesar do nome, as "Atualidades" cinematográficas apresentam
frequentemente uma visão retificada da atualidade, sem falar das puras
falsificações feitas pelos regimes ditatoriais, que não se contentam,
geralmente, com a censura mais ou menos insidiosa, mas praticam verdadeiras
encenações supervisionadas pelo poder (GAUTHIER, 2011, p. 262-263).

Gauthier evoca a problemática das falsificações e da censura perpetradas por regimes ditatoriais nas "Atualidades Jornalísticas", conforme temos apontado. No entanto, quando Canijo maneja o material original, por meio da montagem, o faz com o intuito de possibilitar uma reflexão crítica do espectador a respeito da propaganda estatal nele presente. Para isso, utiliza várias estratégias, entre elas: a) a manipulação de sons e imagens (em sua maioria produzidos pelo próprio regime); b) a presença de refugiados em Portugal durante os anos de guerra; c) os depoimentos de três estrangeiros famosos de passagem por Lisboa em 1940.

Enfim, Fantasia Lusitana é um documentário elaborado praticamente sem o uso de câmeras ${ }^{1}$. As filmagens, fotografias, canções, testemunhos, discursos e notícias, entre outros, produzidos há quase oitenta anos, são reorganizados e montados de forma a suscitar o pensamento crítico por parte do espectador sobre um período histórico conturbado em função da Segunda Guerra Mundial. Diante desse cenário, Portugal se

\footnotetext{
${ }^{1}$ É importante ressaltar que as câmeras foram utilizadas em Fantasia Lusitana apenas para a filmagem de imagens estáticas, como fotografias, reproduções de jornais e revistas ou documentos consulares.
} 
mostra como um "oásis de paz", se vangloriando de sua neutralidade e alheando a sua população da gravidade bélica, ou seja, vivendo, de fato, uma "fantasia lusitana". O próprio Canijo, em entrevista a Vasco Câmara, do jornal Público, fala da necessidade de se repensar Portugal no pós-salazarismo:

Há uma coisa que percebi ao fazer o filme: o mito da gloriosa História de
Portugal está enraizado na cultura portuguesa. Estamos convencidos de que
temos uma História gloriosa. Isso percebe-se ao ver a Exposição do Mundo
Português: continuam a ser esses os mitos dos miúdos do liceu. E não foi nada
disso, não houve implantação em lado nenhum. Gosto muito da frase do
Fernando Pessoa que aprendi quando tinha 15 anos: o mal em Portugal é o
excesso de civilização dos incivilizados. No fundo, é igual a frase do José Gil:
pior do que a ausência de forma é a arrogância de se tornar forma (CÂMARA,
2010).

Por fim, por mais profícuo que tenha se tornado o cinema português com o fim da censura após o 25 de abril, o governo de Salazar não foi de todo abordado. Segundo Carolin Overhoff Ferreira, "A partir dos anos 80, a ditadura salazarista foi raramente temática no cinema português, dando assim pouca continuidade ao questionamento do regime autoritário nos documentários realizados logo após a Revolução do Cravos" (FERREIRA, 2014, p. 265). A pesquisadora informa que temas como o colonialismo foram bastante recorrentes na década de 1990, e que "apenas no novo milénio o regime autoritário de Salazar ganha maior destaque" (FERREIRA, 2014, p. 265), citando Natureza Morta (2005) e 48 (2009) de Susana de Sousa Dias, e Fantasia Lusitana (2010) de João Canijo, nosso objeto de estudo nesta dissertação.

\section{João Canijo}

O diretor português João Canijo, nascido no Porto em 1957, alcançou uma posição de destaque no cinema contemporâneo de seu país. Ativo desde a década de oitenta do século XX, Canijo tem um vasto currículo, começando pelo seu primeiro contato profissional com o mundo cinematográfico, quando foi assistente de cineastas como Manoel de Oliveira e Wim Wenders. Assume, posteriormente, a direção de projetos televisivos como as séries Alentejo sem Lei (1990) e Sai da minha Vida (1996), bem como a direção de seus próprios filmes.

Realizador de mais de uma dezena de películas, Canijo estreia com o longa Três Menos Eu (1988), passando por Sapatos Pretos (1998) e ganha os Globos de Ouro de melhor filme em 2005, 2012 e 2014 com Noite Escura (2004), Sangue do meu Sangue (2011) e É o Amor (2013). Além disso, o diretor portuense também conquista o Prémio 
Autores de 2012 com o longa Sangue do meu Sangue nas categorias melhor argumento e melhor filme.

Referentemente à participação do realizador em eventos internacionais, Daniel Ribas, investigador que estuda a obra fílmica de Canijo, informa que o cineasta “[...] teve sucessivas presenças em vários festivais (San Sebastián, Copenhaga, Haifa, Montreal, São Paulo, Toronto), de que são destaque as presenças consecutivas na Un certain regard, secção paralela do Festival de Cannes" (RIBAS, 2014a, p. 275).

O seu trabalho mais recente como diretor é o longa Fátima (2017), que estreou nas salas de cinema portuguesas em 27 de abril de 2017. Esta película aborda a temática da fé e conta a história de um grupo de mulheres que parte do distrito de Bragança em peregrinação à cidade de Fátima, ou seja, um trajeto de aproximadamente quatrocentos e trinta quilômetros percorridos a pé. Fátima estreia no ano do centenário das supostas aparições de Nossa Senhora aos pastorzinhos na Cova da Iria.

Dentre a filmografia de João Canijo há quatro documentários, sendo eles o próprio Fantasia Lusitana (2010); Trabalho de Actriz, Trabalho de Actor (2011), referente ao processo criativo dos atores a partir das filmagens de Sangue do meu Sangue; Raul Brandão era um grande escritor... (2012), que investiga a memória acerca desse escritor nas terras em que ele viveu; Portugal - um dia de cada vez (2015), em parceria com a atriz e diretora Anabela Moreira, fruto da pesquisa feita por ela no norte do país para compor as personagens do longa Fátima. Apesar da extensa obra do diretor, o nosso recorte se restringe apenas ao documentário de 2010.

\section{Fantasia Lusitana}

“"Fantasia Lusitana' é a história da castração de um país a que, soterrado debaixo de tralha beata e saudosista, não foi concedida a possibilidade de se assumir" (OLIVEIRA, 2010). Assim define o crítico de cinema Luís Miguel Oliveira, do jornal Público, o documentário de João Canijo de 2010.

Fantasia Lusitana não teve tanta circulação quanto um filme de ficção teria em seu lançamento. Segundo a agência de notícias Lusa, "Depois da antestreia no IndieLisboa [22/04/2010], 'Fantasia Lusitana' chegará aos cinemas no dia 29 de Abril, mas apenas em duas salas em Lisboa e no Porto" (LUSA, 2010). A exibição em um 
número reduzido de salas apenas em duas cidades, mesmo estas sendo as maiores cidades portuguesas, indica que o filme não teve tanta circulação, o que é compreensível ao se tratar de um documentário. O realizador tinha a expectativa de que o público de Fantasia Lusitana fosse a geração mais nova, aquela que não viveu sob o regime salazarista, conforme divulgado pela agência Lusa: "João Canijo espera que o filme seja visto sobretudo por quem não tem memória daquela época, como a geração do seu filho, de 17 anos" (LUSA, 2010).

No entanto, em entrevista concedida a Diana Mendonça do Canal Cascais, o diretor revela que não foi isso que aconteceu:

Diana Mendonça: E este é um filme para quem se lembra do momento, para quem conhece a história, ou também para os jovens que provavelmente nem sabem, não têm tanto a noção do que se passou nessa época?

João Canijo: Para mim é fundamentalmente um filme para os jovens que não têm noção nenhuma do que este país foi. Infelizmente, o filme obteve um sucesso de público bastante grande, mas eu sei que a média etária das pessoas que o iam ver eram as pessoas que já conheciam.

DM: Então acha que esta não pode ser uma espécie de uma lição de história para o público mais jovem?

JC: Uma lição de história eu não diria, mas verem e sentirem como se vivia em Portugal até os anos sessenta, até os anos setenta, finais dos anos sessenta, era muito instrutivo, acho eu. Não é educativo, é instrutivo, é perceberem de onde vêm e o que é que foi, como é que cresceram os pais deles (MENDONÇA, 2010, 01:38-02:29).

Podemos dizer que esta película foge da natureza dos demais trabalhos do realizador, pois é "Um filme para o qual não pegou uma única vez na câmera nem escreveu qualquer texto" (HALPERN, 2010). Isso porque, constituído exclusivamente por material de arquivo, o documentário "evidencia a montagem como ferramenta primordial na linguagem cinematografia” (HALPERN, 2010).

Toda produção cinematográfica envolve um conjunto de profissionais até que o produto final chegue aos cinemas. Não é diferente no caso desse documentário, mesmo que tenha sido todo estruturado a partir de material já existente. A esse respeito, é importante ressaltar o trabalho de edição e montagem de João Braz, profissional que construiu uma sólida trajetória dentro do cinema português, tendo trabalhado com João Canijo em outros filmes, além de diversos cineastas como Margarida Cardoso, João Botelho ou Fernando Vendrell. Assim, embora Canijo receba os créditos pela realização do documentário, é importante considerar o trabalho das demais equipes envolvidas para 
a sua conclusão, como o levantamento de material em arquivos, a montagem e edição de som e imagem, a tradução de textos estrangeiros, dentre outros.

Ademais, Fantasia Lusitana se encontra na categoria de filme de encomenda. João Trabulo, criador da produtora de cinema independente Periferia Filmes, entrou em contato com Canijo convidando-o para dirigir um documentário que abordasse a passagem de refugiados famosos por Portugal durante a Segunda Guerra Mundial. Canijo aceitou realizá-lo, porém, com algumas alterações, conforme revela a Inês Monteiro:

Foi uma encomenda que a produtora do filme me fez. Tinham um projecto que andavam a desenvolver sobre os refugiados famosos em Lisboa durante a guerra e propuseram-mo. Eu vi o que tinham e disse-lhes que aceitava, mas que não ia ser nada daquilo porque, pouco tempo antes, um professor de História do meu filho, que andava no $9^{\circ}$ ano, deu uma aula em que explicou algumas das virtudes do salazarismo. Então decidi fazer o filme para o meu filho, para os miúdos, e explicar-lhes como as coisas realmente eram (MONTEIRO, 2011).

Uma vez definidas as premissas do documentário, Canijo teve acesso ao material coletado previamente, conforme declara em entrevista concedida a Vasco Câmara:

[...] isso foi resultado de pesquisa de alguém que se formou em História em França e que estava a trabalhar para o João Trabulo, o Hugo dos Santos. Durante meses pesquisou tudo sobre a época e o tema. Fazia a pesquisa, mostrava o que tinha encontrado, em imagens ou textos. Passou semanas, por exemplo, no Arquivo Nacional das Imagens em Movimento (ANIM), fazia resumos do que lá estava, e a partir daí fazíamos a pre-selecção, que tinha um custo, para encomendar (CÂMARA, 2010).

Boa parte do material utilizado em Fantasia Lusitana é proveniente de um jornal de atualidades chamado Jornal Português. A respeito desse veículo de comunicação, Ricardo Braga explica:

Produzido pela Sociedade Portuguesa de Actualidades Cinematográficas (SPAC), o Jornal Português (1938-1951) foi o único noticiário cinematográfico (oficial) realizado em Portugal que atravessou dois períodos conflituosos da história mundial: 1936-1939 e 1939-1945, tornando-se num objecto de estudo privilegiado daqueles períodos históricos (BRAGA, 2005, p. 129).

No geral, os jornais de atualidades (ou cinejornais) pertenciam à uma modalidade de registro usada pelas propagandas de regimes autoritários para difundir seus princípios através de informativos (que adquiriam uma aura de notícia) exibidos nas salas de cinema antes da projeção dos filmes. De fato, o Jornal Português, sob o governo ditatorial e fascista de então, era especializado em exaltar o Estado Novo, seus líderes e a sua política. Informava também acerca de acontecimentos triviais, como inaugurações de prédios públicos, festas civis e religiosas, exercícios militares, passagem de celebridades por 
Portugal, celebrações de efemérides, entre outros assuntos análogos. No entanto, por trás das informações que eram veiculadas, havia um ar de veneração aos Chefes da Nação, a transmissão de valores morais e religiosos alimentados pelo regime e a valorização dos usos e costumes portugueses, ou seja, toda a ideologia que caracterizou o salazarismo.

Além disso, Fantasia Lusitana também traz algumas filmagens das ruas de Lisboa que não foram produzidas pela propaganda, e que, portanto, foram captadas de forma clandestina, conforme explica o próprio realizador:

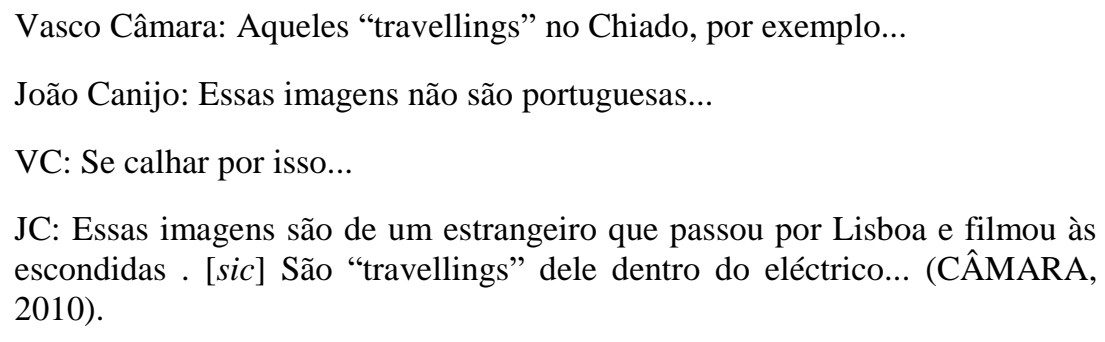

Há também gravações de hostilização contra lojas de judeus na Alemanha, militares nazistas desfilando em ruas alemãs e bombardeios aéreos envolvendo países beligerantes. Embora imagens como essas não fossem de fonte portuguesa, elas foram usadas em Portugal para explicar à população o que se passava no resto da Europa e para asseverar que, segundo a ideologia vigente, os portugueses não estavam sujeitos àquelas atrocidades graças à política externa de Salazar.

Imagens fotográficas também estão presentes em Fantasia Lusitana e são elas que retratam mais fielmente a passagem dos refugiados estrangeiros por Portugal, uma vez que pouco material fílmico foi encontrado a esse respeito. Essas fotografias revelam vários estrangeiros, que se distinguem dos portugueses pelo biotipo e pelo modo diverso de se vestir, das mais diversas idades, em grupos, famílias ou sozinhos, alguns com o olhar incerto, o semblante carregado, outros visivelmente exaustos, seja ao lado de sua bagagem, seja tentando se comunicar com a população local ou simplesmente sentados, aguardando, já que Lisboa era para eles um local de passagem, uma rota de fuga da Europa, uma vez que Portugal declarou neutralidade durante a Segunda Guerra Mundial.

Ainda considerando as imagens estáticas (que adquirem movimento na película), destacamos fotos da imprensa portuguesa e internacional, isto é, de jornais e revistas, quer da capa, quer das páginas internas, exibindo manchetes, títulos de artigos, notícias e fotografias. Há também fotos de documentos consulares, como pedidos de visto em passaporte, concedidos a estrangeiros das mais diversas nacionalidades europeias pelos 
consulados portugueses naqueles países. Esses documentos revelam as individualidades por trás daqueles pedidos, já que o espectador lê o nome, a data de nascimento, a cidade onde o consulado português estava operando, bem como contempla os rostos dos solicitantes, o que remete à existência de pessoas por trás de cada solicitação, humanizando, de certa forma, o teor burocrático.

Por fim, é necessário levar em conta a presença da trilha sonora (banda sonora em Portugal) do documentário. Já que Fantasia Lusitana é um filme constituído exclusivamente por imagens de arquivo, parte da música presente nele faz parte das imagens originais, que são exibidas conforme foram à época. Nesse aspecto, encontramos essencialmente música instrumental de fundo, que corrobora as imagens projetadas, como, por exemplo, música marcial nas cenas que exibem desfiles militares, ou música ligeira e alegre em excertos como os da Exposição do Mundo Português.

Ademais, a música inserida no processo de montagem do documentário foi devidamente selecionada, com o intuito de gerar significado. Neste caso, essas canções possuem letra que, juntamente com a sua melodia, ditam a tônica dentro da película, contrastando ou corroborando as imagens que estão sendo mostradas. Dentre este segundo grupo musical podemos citar uma canção de exaltação à Salazar, cantada por vozes soturnas, ou a canção We'll meet again, interpretada pela cantora inglesa Vera Lynn, enquanto aparecem imagens de celebração pela ocasião do final da Segunda Guerra Mundial na Europa em maio de 1945.

Ainda dentro do âmbito dos recursos auditivos, é imprescindível ressaltar os relatos de três refugiados sobre o período em que permaneceram em Lisboa em 1940, aguardando para deixar a Europa. Essas memórias são agregadas à película em voz off em seus idiomas originais, mas não têm a função direta narrativa no sentido de elucidar o espectador a respeito do que é exibido. São trechos das reminiscências desses estrangeiros que foram publicadas posteriormente e que testemunharam o que viram e sentiram durante sua permanência em Portugal. Dado o contraste entre a realidade do país que os hospedava e o contexto das nações em guerra de onde provinham, esses apontamentos se transformam em expediente engenhoso utilizado na montagem.

Os autores dessas memórias têm em comum o fato de serem intelectuais, isto é, de estarem ligados ao mundo da poesia, da literatura ou da dramaturgia. São o médico e escritor judeu-alemão Alfred Döblin (1878-1957), consagrado pelo seu romance Berlin 
Alexanderplatz (1929), cuja voz é interpretada pelo ator Rüdiger Vogler; a dramaturga e atriz alemã Erika Mann (1905-1969), filha do escritor Thomas Mann (1875-1955), membro da companhia de teatro die Pfeffermühle, conhecida por satirizar o nazismo, a quem dá voz a atriz Hanna Schygulla; o aviador, escritor e ilustrador francês Antoine de Saint-Exupéry (1900-1944), autor do célebre livro O Pequeno Príncipe (1943), intitulado O Principezinho em Portugal, cujas memórias são presentificadas através da voz do ator Christian Patey.

Por meio da inserção da voz off desses atores, Canijo cria uma relação entre o que se vê e o que se ouve, isto é, entre a exibição das imagens e sons originais e as vozes estrangeiras que interpretam as memórias escritas deixadas pelos três refugiados. $\mathrm{O}$ mesmo recurso é aplicado à voz de Salazar, recuperada a partir de registros radiofônicos das leituras de alguns dos discursos que fez à época, sobreposta a imagens diversas, inclusive à sua própria.

No demais, o filme não conta efetivamente com a presença de um narrador a fim de elucidar ou contextualizar o que é exibido, exigindo que o espectador, preferencialmente, possua este conhecimento. Acerca deste assunto, Canijo informa ao jornalista Vasco Câmara que "de propósito não tem explicação. O meu filho tem 16 anos, gostou muito, mas disse que era preciso voz 'off'. Mas desde o princípio houve essa recusa. O silêncio é mais eloquente" (CÂMARA, 2010).

Na opinião de Daniel Ribas,

O facto de não existir uma voz off para contextualizar a história sublinha a ironia que existe nessas sequências, pelo menos do ponto de vista de um espectador esclarecido que as percebe como sendo hoje profundamente problemáticas. Essa dimensão torna-se mais evidente porque a situação exposta pelas atualidades é contrastada pela segunda camada do filme, que é realizada pelas leituras de textos dos três refugiados famosos em Lisboa. Portanto, há uma espécie de releitura das atualidades, que expõe o seu discurso de ilusão (RIBAS, 2014a, p. 279).

Já para a pesquisadora Ana Salgueiro Rodrigues,

[...] a ausência de locução em Fantasia Lusitana e a aparente relutância do realizador em manipular as imagens de arquivo podem ser entendidas como a rejeição do modelo cinematográfico manipulador do Estado Novo (um dos criadores da fantasia lusitana que Canijo desconstrói no seu filme e para a qual remete o seu título) e como a defesa de uma filmografia mais próxima do cinema-directo, supostamente capaz de mostrar a realidade tal qual ela é (RODRIGUES, 2010, p. 73).

Portanto, graças à seleção, manipulação, arranjo e montagem de tanto material resgatado de arquivos, Fantasia Lusitana consegue, em pouco mais de uma hora, revelar 
a construção ideológica salazarista ao apresentar dois níveis de realidade ${ }^{2}$, isto é, o nível da propaganda, tal qual foi exibida a seu tempo, e o nível da percepção vivida pelos estrangeiros, que conheciam a guerra de perto e que sentiam um estranhamento em Portugal, onde aparentemente se vivia como se além de suas fronteiras a Europa não estivesse em convulsão. Apesar de ser um filme de encomenda, Canijo fala a respeito da liberdade que teve para realizar o documentário, bem como aborda a questão dos dois níveis de realidade:

De qualquer forma, o filme passou a ser meu, e ninguém me impôs o que quer que fosse. E logo na primeira sinopse já "Fantasia Lusitana" nada tinha a ver com a passagem de refugiados. Já tinha mais a ver com uma ideia minha, algo que eu intuía que era verdade: os dois níveis de realidade em Portugal, o mundo em guerra e a fantasia do país neutral, o mito criado por Salazar (CÂMARA, 2010).

Ao apresentar a montagem a partir dessas duas perspectivas, o documentário expõe a fantasia que os portugueses viviam em seu país, doutrinados por uma ditadura que se autoproclamava branda, paternal e indispensável.

Em termos de estrutura, esta dissertação possui cinco capítulos além da conclusão. O primeiro capítulo, intitulado "O mundo da fantasia", não apenas explica a formação da base ideológica do Estado Novo, mas também versa sobre como ocorreram as construções das imagens de Salazar como líder da nação e de Portugal como país neutro durante a Segunda Guerra Mundial. O segundo capítulo, cujo nome é "A contestação da fantasia", analisa os trechos das memórias de Döblin, Mann e Saint-Exupéry presentes no documentário, desvelando como o ponto de vista desses estrangeiros que viveram a guerra de perto divergia do posicionamento do governo português e de sua propaganda. "A alternância das camadas" é o nome do terceiro capítulo, que trata como a montagem do documentário intercala posicionamentos pertencentes às duas camadas analisadas anteriormente. O quarto capítulo, "A desconstrução da fantasia”, procura fazer a análise fílmica de Fantasia Lusitana com foco em sua montagem e nos métodos de edição utilizados para desconstruir a propaganda salazarista. Por fim, o quinto capítulo, "A astúcia do regime salazarista", explora a parte final do documentário fazendo uma síntese do que foi o Estado Novo, além de analisar algumas estratégias usadas por Salazar após o final da guerra que permitiram que ele permanecesse no poder ainda por muito tempo.

\footnotetext{
${ }^{2}$ É necessário ressaltar que há um terceiro nível que controla e permeia todo o filme, isto é, o nível autoral.
} 


\section{CAPÍTULO 1: O MUNDO DA FANTASIA}

\subsection{Com a palavra, António de Oliveira Salazar}

É importante destacar que a partir do ano de 1936, quando se comemorou o décimo aniversário do golpe militar que encerrou a breve República Portuguesa, uma série de princípios passaram a ser disseminados pelo país a fim de controlar a população e de manter o statu quo. Segundo o historiador Fernando Rosas,

[...] esse sistema de valores - as "verdades indiscutíveis" proclamadas no ano $\mathrm{X}$ da revolução nacional -, pela sua própria natureza positiva, pela mundivisão totalizante que transportava, exigiu e criou um aparelho de inculcação ideológica autoritária, estatista, mergulhado no quotidiano das pessoas (ao nível das famílias, da escola, do trabalho, dos lazeres), com o propósito de criar esse particular "homem novo" do salazarismo (ROSAS, 2001, p. 1.031).

Assim, gostaríamos de refletir sobre a base ideológica do Estado Novo e de analisar de que maneira tais princípios foram incutidos na mente da população portuguesa, influenciando sua forma de pensar e de agir. A esse respeito, Fernando Rosas identifica sete mitos e os chama de "mitos fundadores de Estado Novo". Para o historiador, o objetivo do regime era

[...] estabelecer uma ideia mítica de "essencialidade portuguesa", transtemporal e transclassista, que o Estado Novo reassumira ao encerrar o "século negro" do liberalismo e a partir da qual se tratava de "reeducar" os portugueses no quadro de uma nação regenerada e reencontrada consigo própria, com a essência eterna e com o seu destino providencial (ROSAS, 2001, p. 1.034).

Por uma questão didática, elencamos e resumimos abaixo os aludidos mitos:

\section{1') O mito palingenético:}

Referia-se à ideia “do recomeço, da 'Renascença portuguesa', da 'regeneração' operada pelo Estado Novo" (ROSAS, 2001, p. 1.034).

\section{$\left.2^{\circ}\right)$ O mito central da essência ontológica do regime ou o mito do novo nacionalismo:}

O Estado Novo "cumpria-se, não se discutia, discuti-lo era discutir a nação" (ROSAS, 2001, p. 1.034). O historiador explica que "o célebre slogan 'Tudo pela Nação, nada contra a Nação’ resume [...] este mito providencialista” (ROSAS, 2001, p. 1.034).

\section{$\left.3^{\circ}\right) \mathbf{O}$ mito imperial:}

Englobava o "seu duplo aspecto de vocação histórico-providencial de colonizar e evangelizar" (ROSAS, 2001, p. 1.034). A ideologia por trás desse mito afirmava que os 
portugueses deviam dar continuidade à "gesta histórica dos nautas, dos santos e cavaleiros" (ROSAS, 2001, p. 1.034) de outrora. Por fim, este mito gerava a ideia dogmática "da nação pluricontinental e plurirracial, una, indivisível e inalienável" (ROSAS, 2001, p. 1.035).

\section{$\left.4^{\circ}\right)$ O mito da ruralidade:}

A ideia de que "Portugal é um país essencial e inevitavelmente rural, uma ruralidade tradicional tida como uma característica e uma virtude específica, donde se bebiam as verdadeiras qualidades da raça e onde se temperava o ser nacional" (ROSAS, 2001, p. 1.035). Aliava-se a este mito, através da propaganda, um espírito "de crítica à industrialização, de desconfiança da técnica, de crítica da urbanização e da proletarização" (ROSAS, 2001, p. 1.035), o que levava à "fundamentação de uma segunda vocação, uma espécie de vocação rural da nação” (ROSAS, 2001, p. 1.035).

\section{5') O mito da pobreza honrada ou o mito da "aurea mediocritas":}

Oriundo e consequente do mito da ruralidade: "[...] a conformidade de cada um com o seu destino, o ser pobre mas honrado, pautavam o supremo desiderato salazarista do "viver habitualmente", paradigma da felicidade possível" (ROSAS, 2001, p. 1.035).

\section{$\left.6^{\circ}\right)$ O mito da ordem corporativa:}

Justificava o porquê de a população precisar ser conduzida por um estadista. Havia

[...] uma certa visão infantilizadora do povo português, gente conformada, respeitadora, doce, algo irresponsável e volúvel, mutável nas suas opiniões, sonhadora, engenhosa mas pouco empreendedora, obviamente insusceptível de ser titular de soberania ou fonte de grandes decisões nacionais, necessitada, portanto, como coisa natural e naturalmente aceite, da tutela atenta mas paternal do Estado (ROSAS, 2001, p. 1.036).

Em consequência disso, surgia "outra vocação da essencialidade portuguesa: uma vocação de ordem, de hierarquia e de autoridade natural" (ROSAS, 2001, p. 1.036).

\section{$\left.7^{\circ}\right)$ O mito da essência católica da identidade nacional:}

Por fim, o último mito "entendia a religião católica como elemento constitutivo do ser português, como atributo definidor da própria nacionalidade e de sua história" (ROSAS, 2001, p. 1.036). 
Todos esses mitos que formaram a base da ideologia do Estado Novo estão presentes amiúde nas cenas de Fantasia Lusitana, no nível representado pela fantasia, já que as imagens utilizadas na montagem do documentário foram originalmente usadas pela propaganda salazarista naquele contexto.

\subsection{A propaganda salazarista se apresenta}

Conforme já mencionamos, Fantasia Lusitana está estruturado em dois níveis, ou seja, o nível da propaganda, vivenciado em Portugal, e o nível do que se passava fora do país, representado pela Segunda Guerra Mundial e pelos que dela fugiam. É, sobretudo, nos minutos iniciais da película que João Canijo permite que o primeiro nível se manifeste livremente antes de sofrer algum tipo de intervenção. Esta estratégia serve para apresentar ao espectador como os portugueses viviam sob o regime de Salazar.

Exemplar, nesse sentido, é a cena introdutória do documentário. A imagem de abertura de Fantasia Lusitana remete à recordação da existência da censura instaurada pelo Estado Novo no período abordado e ao constrangimento imposto a cineastas, autores e dramaturgos, pois suas obras eram visionadas e dependiam da aprovação desse órgão opressor. Nela, o espectador vê a imagem de um escudo levemente inclinado à direita contendo cinco escudetes em seu interior, os quais formam uma cruz. Há um ramo ao lado direito do escudo na perspectiva de quem olha para a tela, sendo que ele circunda a parte inferior, e, em parte, o lado direito do escudo. Adjacente à essa imagem, lê-se o seguinte texto: "visado pela INSPECÇÃO DOS ESPECTÁCULOS BF • 22” (Figura 01):

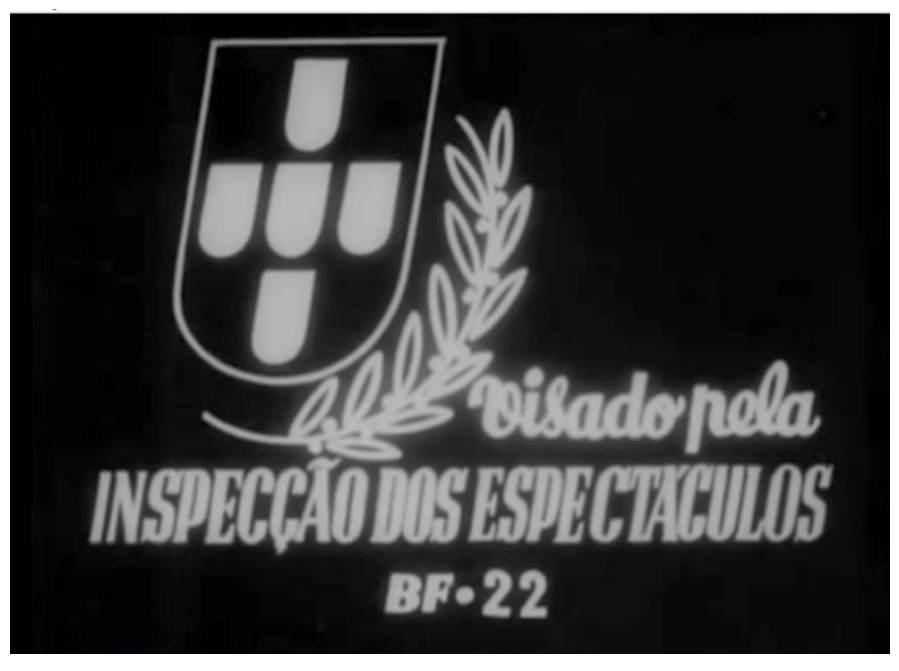

Figura 01: Fotograma da imagem inicial de Fantasia Lusitana, que faz referência à presença da censura no Estado Novo. 
Por se tratar da primeira imagem da película, ela contextualiza e anuncia a tônica do filme, pelo menos no nível da fantasia, uma vez que agrega símbolos nacionais (brasão de armas de Portugal, com seu escudo e escudetes) e religiosos (cruz e ramo), explorados pelo Estado Novo. O texto presente remete à necessidade do aval da censura para qualquer material que viesse a público no período. Ao iniciar o seu documentário com essa imagem anacrônica, João Canijo explicita para o espectador contemporâneo a desejada onipresença dos órgãos censores. Mais que isto, dá a ideia de que ele próprio tivesse sido autorizado a exibir Fantasia Lusitana, como se nenhuma ameaça pairasse em relação à imagem idealizada do regime, quando, na verdade, o que o documentário faz é justamente o contrário. Ou seja, ironicamente, é como se a censura tivesse liberado para exibição um filme que, em vez de reforçar a ideologia salazarista, irá desconstrui-la. Compondo a cena inicial acima é necessário destacar a presença de uma música orquestrada típica, semelhante à utilizada em cenas de batalhas em filmes épicos ou em desfiles militares nas décadas de 1930 e 1940, que corrobora a construção do significado e faz com que o espectador perceba sobre qual momento histórico o filme irá retratar.

As cenas iniciais propriamente ditas foram extraídas do cinejornal Mocidade Vitoriosa (1939), promovido pela Secção de Cinema do Secretariado da Propaganda Nacional e em cuja apresentação trazia os dizeres "Um filme da Mocidade Portuguesa nas festas do 28 de Maio de 1939"3. A primeira cena de Fantasia Lusitana mostra jovens segurando uma bandeira sinalizadora em cada uma de suas mãos, fazendo exercícios de sinalização enquanto a locutora soletra o que estão comunicando. Ouve-se então na voz feminina: “T, U, D, O. Tudo. P, E, L, A. Pela. N, A, C, cedilha, A, til, O. Nação. Tudo pela Nação" (FANTASIA LUSITANA, 2010, 00:52 - 01:23). No momento em que a locutora enuncia estas três palavras, as imagens do Presidente da República, o General Oscar Carmona, e do Presidente do Conselho de Ministros, António de Oliveira Salazar, são exibidas na audiência e em primeiro plano, recordando quem eram os representantes máximos da nação.

Ao escolher principiar Fantasia Lusitana com um dos slogans mais conhecidos no regime e em cuja totalidade se lia "Tudo pela Nação, nada contra a Nação", o realizador inicia sua obra fílmica introduzindo ao seu interlocutor, isto é, ao espectador, o segundo mito ideológico fundador do Estado Novo definido por Rosas (2001), ou seja,

\footnotetext{
${ }^{3}$ Disponível em <http://www.cinemateca.pt/Cinemateca-Digital/Ficha.aspx?obraid=3488\&type=Video $>$. Acesso em 12 out. 2017.
} 
o mito central da essência ontológica do regime. O historiador lembra que o mito por trás da ideia do slogan acima apregoava que "o Estado Novo surgia [...] como a institucionalização do destino nacional, a materialização política no século XX de uma essencialidade histórica portuguesa mítica” (ROSAS, 2001, p. 1.034).

Ainda extraído de Mocidade Vitoriosa (1939), vemos a seguir um jovem vestindo um uniforme militar tocando um clarim para anunciar a entrada da "grande classe de ginástica", composta por milhares de jovens da Mocidade Portuguesa, em um estádio. Esses rapazes estão trajando camisetas regatas claras e shorts brancos, descritas pela locutora como sendo "camisolas alaranjadas" que "fazem um efeito lindo ao sol". Eles iniciam suas exibições físicas em perfeita sincronia, o que valoriza a ideia de disciplina, organização e respeito hierárquico previsto pelo mito da ordem corporativa.

Gostaríamos de evidenciar que os jovens pertencentes à "classe de ginástica" mantêm os cenhos carregados enquanto fazem suas apresentações físicas, os lábios estão cerrados e as testas estão franzidas (Figura 02). Formado apenas por membros do sexo masculino, tal expressão facial pode ser interpretada como uma demonstração de virilidade, intimidação ou sinal de força e bravura, uma vez que estavam se apresentando para, entre outros, o Presidente da República e o Presidente do Conselho, os chefes máximos da nação, o que justificaria exibir tais qualidade, ou os valores pátrios.

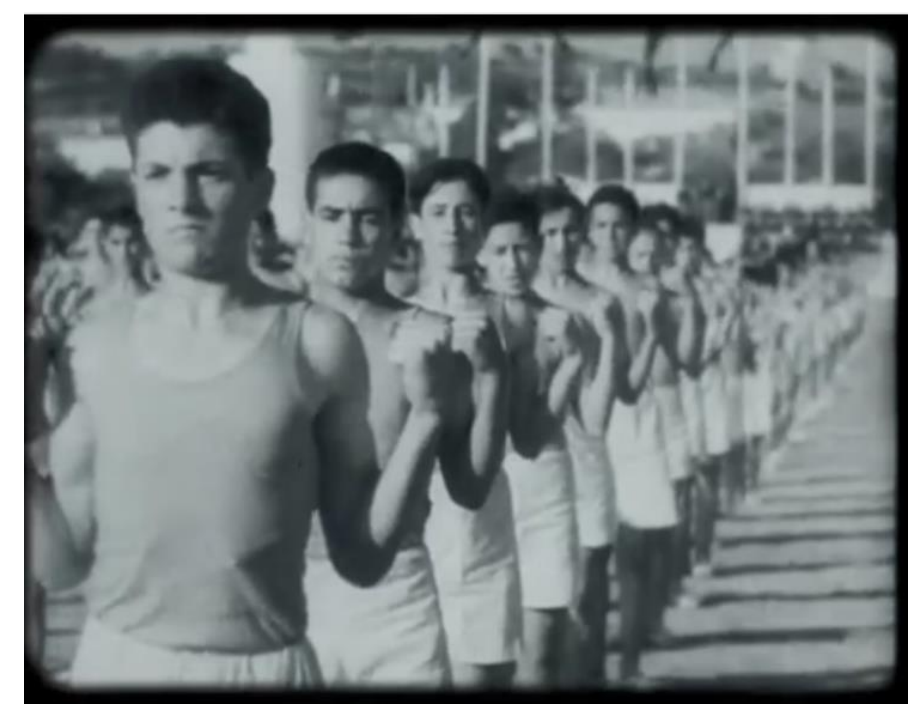

Figura 02: Jovens da Mocidade Portuguesa fazem exibição de ginástica nas celebrações do décimo terceiro aniversário da Revolução Nacional em 1939.

É pertinente apontar que esta sequência de Mocidade Vitoriosa (1939) dentro de Fantasia Lusitana continua com imagens de adolescentes espanhóis, alemães e italianos 
- o que é enfatizado pela narração da locutora - que foram convidados para a celebração dos treze anos do golpe militar de 1926. Por mais comum que a presença desses representantes estrangeiros naquele evento pudesse transparecer aos olhos do espectador do final dos anos trinta, a audiência atual, graças ao distanciamento temporal, percebe o alinhamento ideológico do governo português com esses países.

O espectador do século XXI tem o conhecimento histórico a respeito do que o nazismo alemão e o fascismo italiano representaram durante a Segunda Guerra Mundial (que iria iniciar ainda naquele ano de 1939) e da truculência com a qual o General Francisco Franco agira durante a recém terminada Guerra Civil Espanhola (1936-1939). Outro aspecto é o fato de que Portugal declarou status de neutralidade durante a guerra. Dessa forma, constatar a representatividade dessas três nações nas festividades portuguesas causa um certo incômodo aos olhos do espectador contemporâneo, sobretudo quando a câmera capta um grupo de jovens alemães sentados ao chão, vestindo o uniforme da Juventude Hitleriana, o qual traz o emblema da suástica nazista no braço esquerdo da camisa (Figura 03). Este símbolo está repleto de carga negativa que o espectador daquela época poderia não compreender, mas que o espectador atento da atualidade percebe, graças aos horrores praticados pelos nazistas, como as invasões territoriais, as perseguições contra as minorias ou a postura antissemita, que levou à criação dos campos de concentração e extermínio.

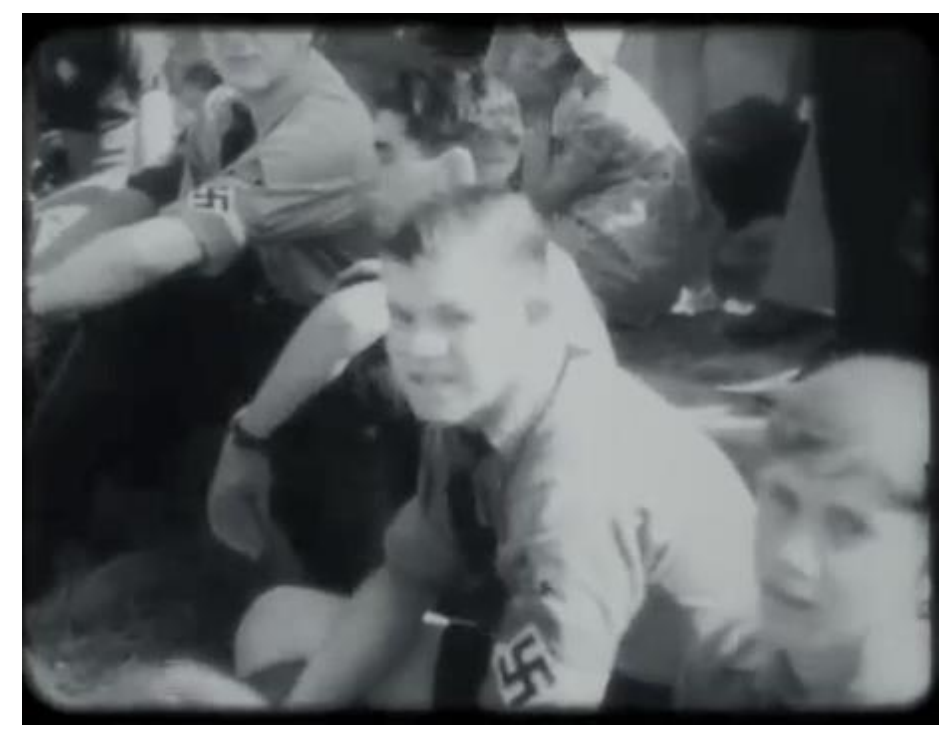

Figura 03: Suástica nazista nos braços de jovens alemães convidados às celebrações do décimo terceiro aniversário da Revolução Nacional portuguesa em 1939.

Portanto, a presença de delegações daqueles três países nas festividades de maio de 1939 denota que o governo português estava sintonizado ideologicamente com eles e 
partilhava de princípios semelhantes, embora cada um dos regimes tivesse as suas peculiaridades. $\mathrm{O}$ fato é que aqueles países eram governados por líderes antidemocráticos, isto é, Salazar, Franco, Hitler e Mussolini. Assim, saber que o Portugal de então mantinha relações amigáveis com aqueles governos causa um certo desconforto na visão moderna e evidencia que havia laços de simpatia mútua entre eles, desconstruindo a ideia da neutralidade absoluta portuguesa divulgada pelo regime depois da eclosão da guerra.

Esta sequência termina com uma imagem bastante significativa e muito comum àqueles quatro países. Trata-se da saudação romana, utilizada nos governos nazista e fascistas, como forma de respeito e submissão aos chefes dessas nações e aos símbolos da pátria. Dessa forma, vemos jovens da Mocidade Portuguesa desempenhando esta saudação, ao mesmo tempo que uma música militar é executada. Como fechamento, a cena termina mostrando os jovens com os braços esticados ao mesmo tempo em que música chega ao seu fim (Figura 04).

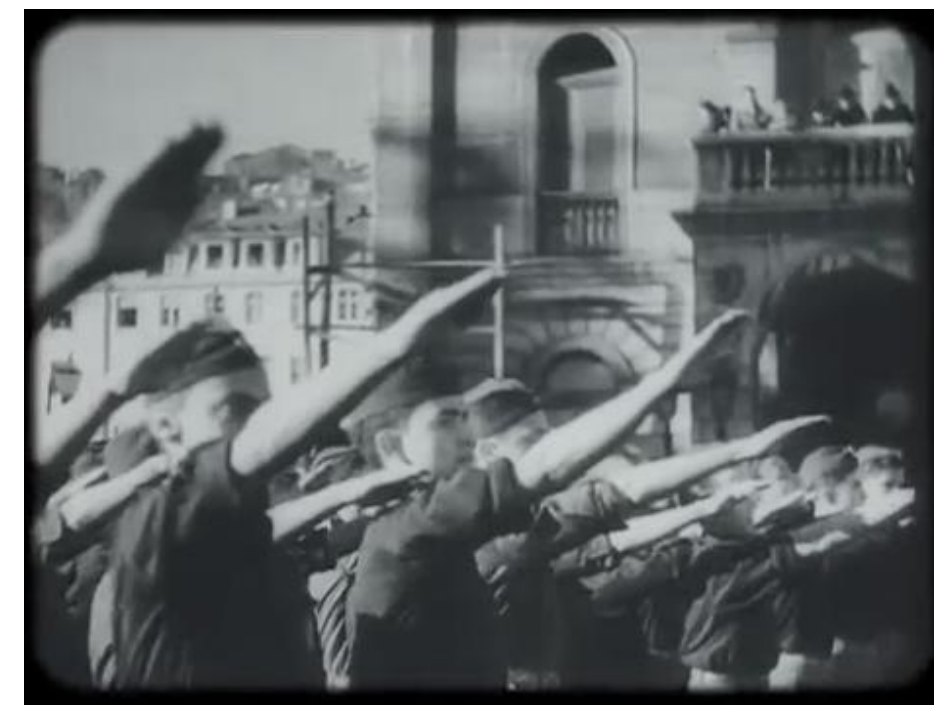

Figura 04: Jovens da Mocidade Portuguesa fazem a saudação romana.

Canijo permite que cenas que representam os valores do Estado Novo português se façam mostrar livremente até os $6 \min 17 \mathrm{~s}$, quando o espectador é surpreendido por imagens da Alemanha nazista. É neste momento que somos levados a refletir que algo muito diverso e perigoso está acontecendo fora de Portugal. Este corte no documentário introduz o mundo nazista, o apoio de parte da população alemã a esse governo, a perseguição contra os judeus e a explicação aos portugueses sobre o que eram os bombardeios aéreos nos países em guerra, naquela época conhecidos por Blitz. 


\subsection{Os discursos de Salazar, ou "a voz de Deus"}

Dentre os materiais que compõem o mundo da propaganda salazarista, isto é, a camada fantasiosa do documentário, destacamos a presença dos discursos de Salazar, lidos por ele próprio. Por se tratarem, em sua maior parte, de arquivos exclusivamente em áudio, a montagem de Fantasia Lusitana os utilizou conjuntamente com imagens usadas pela propaganda à sua época, que mostram um mundo imaginário divulgado pela ideologia do regime.

João Canijo, em entrevista a Vasco Câmara, sintetiza o que representam para ele os discursos do ditador:

Salazar era muito esperto. Aqueles discursos são extraordinariamente bem escritos - para não se perceber o que ele está a dizer... tem plena consciência de que está a falar para ignorantes que gostam de ouvir o senhor falar bem. No fundo, são lugares-comuns que parecem ideias metafísicas (CÂMARA, 2010).

Assim, a eloquência do Presidente do Conselho evidencia aquilo que é exibido pela montagem, gerando significado e trazendo coerência entre som e imagem. Em outras palavras, o que é ouvido na voz mansa de Salazar também é visto através das imagens visuais, o que torna a montagem engenhosa, pois, além de trabalhar com exageros e com a ironia em certas partes, acaba por ridicularizar o Estado Novo, conforme iremos abordar em breve.

Como não há um narrador em voz off, ou legendas que forneçam explicações aprofundadas acerca das imagens, a voz de Salazar, ora num tom terno e paternal, ora com uma entonação enérgica, serve como guia nesses momentos em que a montagem apresenta a estrutura ideológica do Estado Novo. Ou seja, é a voz do próprio líder máximo da nação que introduz e define aquele regime, pelo menos na camada fantasiosa do filme. Como muitas vezes não o vemos proferir os discursos, uma vez que foram recuperados de transmissões radiofônicas, tem-se a impressão que aquela é a "voz de Deus". João Canijo, em entrevista concedida a Francisco Ferreira, traz este assunto à tona: “"E porquê ouvir hoje Salazar, pela primeira vez, em Dolby Surround, acima dos outros elementos da banda sonora?' perguntámos na semana passada a João Canijo. [...]. Irónico, Canijo respondeu: 'é que, naquele tempo, a voz de Salazar era a voz de Deus..." (FERREIRA, $2010)^{4}$.

\footnotetext{
${ }^{4}$ É importante distinguir que o termo "voz de Deus", aqui empregado por João Canijo, nada tem a ver com o conceito cinematográfico homônimo, aplicado normalmente a documentários, cf. Nichols (2013).
} 
O cineasta lembra que "naquele tempo", ou seja, durante o período do governo Salazar, o ditador podia ser considerado a personificação de Deus, pois, conforme o mito da ordem corporativa definido por Rosas (2001), os portugueses precisavam de alguém esclarecido e de pulso firme que os dirigisse e lhes ditasse as normas. Do alto de sua tribuna, sua voz se tornava lei, assim como a voz do Deus do antigo testamento se manifestava e se cumpria. Pode-se dizer que Salazar não precisava aparecer para ser obedecido.

Analisando os tipos de vozes utilizadas em documentários, o teórico e crítico de cinema Bill Nichols (2013) explica que:

Cada documentário tem sua voz distinta. Como toda voz que fala, a voz fílmica tem um estilo ou uma "natureza" própria, que funciona como uma assinatura ou impressão digital. Ela atesta a individualidade do cineasta ou diretor, ou, às vezes, o poder de decisão de um patrocinador ou organização diretora (NICHOLS, 2013, p. 135).

Não queremos com isso dizer que a voz de Salazar seja a voz de Fantasia Lusitana em sua totalidade. Entretanto, ela representa a camada do documentário pertencente à propaganda estatal. Logo, podemos entender que, como Chefe da Nação, é a voz de Salazar que traça a linha mestra aos portugueses.

Referentemente ao conceito de "voz de Deus" dentro dos estudos de cinema, mais especificamente empregado em documentários, Nichols (2013) explica que

A forma mais explícita de voz é, sem dúvida, aquela transmitida pelas palavras faladas ou escritas. Elas são palavras que representam o ponto de vista do filme diretamente e às quais nos referimos, caracteristicamente, como comentário com "voz de Deus" ou "voz da autoridade" (NICHOLS, 2013, p. 78).

Para ele, essa voz divina representaria "o ponto de vista do filme diretamente". Como já mencionamos, Fantasia Lusitana possui camadas independentes que se entrelaçam, porém, cada uma delas possui o seu próprio ponto de vista. Concordamos que a voz de Deus (ou voz da autoridade), interpretada pelo próprio Salazar, coadune com a perspectiva do Estado Novo apenas na sua própria camada e quando o realizador o deseja, fato percebido através da montagem. Em sua totalidade, o documentário procura desconstruir a ideologia do regime.

Ainda a esse respeito, Daniel Ribas (2014a) afirma que: "Essa voz do líder da nação é quase sempre usada como um eco [...], ampliando a suposta importância desses discursos e da sua propagação como ideias que continuam a ser um elemento discursivo nas visões atuais da identidade portuguesa" (RIBAS, 2014a, p. 278). 
Parece ser o efeito produzido pela voz amplificada de Salazar que João Canijo pretende mostrar nas partes do documentário que retratam o mundo fantasioso sob o jugo do Estado Novo. São justamente trechos desses discursos que passaremos a analisar a partir de agora.

Esses excertos corroboram aquilo que Fernando Rosas chamou de mitos ideológicos fundadores do Estado Novo, já vistos anteriormente. O primeiro momento em que a voz de Salazar é ouvida neste documentário, coincide com a imagem exibida anteriormente (Figura 04), quando os jovens da Mocidade Portuguesa estão com os braços estendidos fazendo a saudação fascista. Logo que a música militar termina, ouvese a voz do ditador: "Quando se é velho e se tem, além de alguns séculos, uma história, sente-se que existem muitos valores e estes são ao mesmo tempo património e imperativos da vida nacional. A razão manda que um se conserve e aos outros sejamos fieis" (FANTASIA LUSITANA, 2010, 2:10 - 2:29).

Depois de um breve salto, o discurso continua:

\begin{abstract}
Quando, ao lado da ponte ou da estrada que lançamos para a comodidade dos povos, reparamos o castelo ou o monumento, reintegramos a pequena igreja secular ou o mosteiro abandonado, alguns não veem que trabalhamos por manter a identidade do ser colectivo, reforçando a nossa personalidade nacional. E é isso que fazemos. Aquelas qualidades que se revelaram e fixaram e fazem de nós o que somos e não outros; aquela doçura de sentimentos, aquela modéstia, aquele espírito de humanidade, tão raro hoje no mundo; aquela parte de espiritualidade que, malgrado tudo que a combate, inspira ainda a vida portuguesa; o ânimo sofredor; a valentia sem alardes; a facilidade de adaptação e ao mesmo tempo a capacidade de imprimir no meio exterior os traços do modo de ser próprio; o apreço dos valores morais; a fé no direito, na justiça, na igualdade dos homens e dos povos; tudo isso, que não é material nem lucrativo, constitui traços do caráter nacional (FANTASIA LUSITANA, 2010, $3: 47-4: 52)$.
\end{abstract}

E finalmente, segue a terceira parte da preleção de Salazar:

Se por outro lado contemplamos a história maravilhosa deste pequeno povo, quase tão pobre hoje como antes de descobrir o mundo; as pegadas que deixou pela terra de novo conquistada ou descoberta; a beleza dos monumentos que ergueu; a língua e literatura que criou; a vastidão dos domínios onde continua, com exemplar fidelidade à sua história e carácter, alta missão civilizadora concluiremos que Portugal vale bem o orgulho de se ser português (FANTASIA LUSITANA, 2010, 5:29 - 5:57).

O discurso acima, inserido logo nos minutos iniciais do documentário, funciona como ferramenta de apresentação ao público contemporâneo daquele mundo que se mantinha à parte do resto da Europa. A maioria dos mitos fundadores propostos por Rosas (2001) se encontram nos excertos acima, como segue: 
- O mito palingenético: "Quando se é velho e se tem, além de alguns séculos, uma história, sente-se que existem muitos valores e estes são ao mesmo tempo patrimônio e imperativos da vida nacional". Salazar enfatiza o passado glorioso de Portugal, nação antiga e cheia de história, e, conforme pretendia o Estado novo, propõe um recomeço àquela nação, resgatando os mitos, heróis e navegadores de outrora. Assim, o trecho "trabalhamos por manter a identidade do ser colectivo, reforçando a nossa personalidade nacional" acentua os esforços feitos pelo Chefe da Nação a fim de reconstruir um país espelhado num passado cheio de esplendor, vivenciados nos séculos XV e XVI. Estes esforços se dão através de uma identidade única e coletiva do povo português.

- O mito imperial: "a facilidade de adaptação e ao mesmo tempo a capacidade de imprimir no meio exterior os traços do modo de ser próprio". O ditador dissemina a ideia de que os portugueses são naturalmente um povo adaptável fora de seu país e que deixam seu legado por onde passam. Além disso, em "a vastidão dos domínios onde continua, com exemplar fidelidade à sua história e carácter, alta missão civilizadora [...]”, Salazar reitera a ideia de permanência dos portugueses nos territórios africanos e asiáticos, pois, segundo ele, possuem a missão de levar civilização àqueles povos.

- O mito da pobreza honrada: “[...] pequeno povo, quase tão pobre hoje como antes de descobrir o mundo". A pobreza aqui é vista como algo positivo, elemento presente desde antes das grandes navegações e que perpassou a história até o momento de enunciação do discurso. Há honra em ser pobre.

- O mito da ordem corporativa: "aquela doçura de sentimentos, aquela modéstia, aquele espírito de humanidade, tão raro hoje no mundo". Ao descrever os portugueses como doces, modestos e humanos, o político acaba por defender, de forma indireta, a necessidade que este povo simples e bom tem de ter um líder que os governe, pois, com características tão passivas e submissas, justifica, portanto, a sua função de governante daquele país.

- O mito da essência católica da identidade nacional: "aquela parte de espiritualidade que, malgrado tudo que a combate, inspira ainda a vida portuguesa". Salazar descreve a religião (espiritualidade) como sendo fonte inspiradora da vida portuguesa. Ora, apesar de Portugal ter status de país laico, 
da religião católica como confissão nacional, fizera da Igreja uma participante essencial no processo de afirmação ideológica do regime, na sua legitimação religiosa e «providencial» e no concurso prestado aos seus aparelhos de inculcação (ROSAS, 2001, p. 1.052).

No discurso de Salazar acima, o ditador não chega a mencionar ideias que representem os mitos da ruralidade e da essência ontológica do regime, porém, eles estão presentes em outros trechos no decorrer do documentário.

\subsection{O desvario de uma nação fechada em si mesma}

Durante a Segunda Guerra Mundial, o governo português buscou incutir em sua população um sentimento de orgulho pelo fato de Portugal não ter aderido à guerra: "Entre a Civilização e o Mal, entre a Democracia e a Tirania, Portugal escolheu... a neutralidade" (OLIVEIRA, 2010), afirma o crítico de cinema Luís Miguel Oliveira do jornal Público. Tal articulação se deu tanto através da propaganda, difundida amplamente pelos meios de comunicação, quanto embutida em eventos festivos. Em 1940 completouse o oitavo centenário da fundação de Portugal e o Estado Novo aproveitou a ocasião para celebrar este evento em grande estilo. A ideologia salazarista primava pelos festejos das efemérides, os quais eram amplamente divulgados, inclusive por meio de materiais panfletários cinematográficos.

É importante ressaltar que uma das características do regime foi a recuperação de determinados personagens históricos, geralmente categorizados como heróis ou conquistadores, a fim de serem utilizados como elementos corroborativos à ideologia do Estado Novo. No que concerne à fundação de Portugal e à figura de Afonso Henriques, o pesquisador Sérgio Gomes considera:

[...] a valorização da Reconquista Cristã e o espírito das Cruzadas da Idade Média constituem o cenário ideal para a narrativa sobre a Fundação de Portugal. Com efeito, a fundação da nação é perspectivada neste contexto de missão de expansão da fé cristã e Afonso Henriques, o arauto dessa missão, é perspectivado numa tripla asserção que sintetiza informações tanto da lenda popular como produção historiográfica: o instrumento de Deus, o chefe do bando guerreiro que luta pela fé cristã e o salvador da nação dos interesses individuais dos senhores feudais [...] (GOMES, 2006-2007, p. 204).

No geral, o regime buscava associar a figura do ditador como sendo o continuador do legado de Afonso Henriques, ou seja, ele "confere a Salazar a missão de continuar o trabalho do fundador da nação combatendo os elementos de instabilidade da Primeira República e inaugurando uma nova fase de regeneração - o Estado Novo" (GOMES, 
2006-2007, p. 205). Aos 03min13s, o documentário exibe a imagem da espada do Rei D. Afonso I (Figura 05) "apoiada em dois sarilhos de espingardas modernas, simbolizando a união imperecível do passado e do presente" (FANTASIA LUSITANA, 2010, 03:08 03:15).

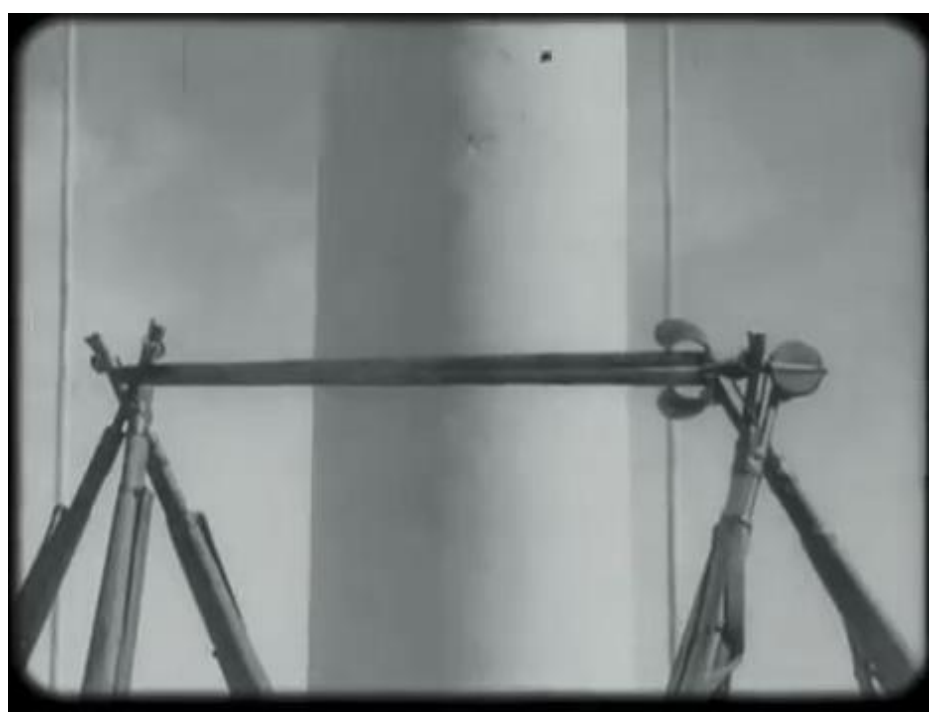

Figura 05: Espada de D. Afonso Henriques apoiada em dois sarilhos de espingardas: vinculação entre o passado e o presente.

No entanto, Fantasia Lusitana busca demonstrar como Portugal se comportou de forma alienada durante os anos de guerra. Isso se faz notório ao analisarmos o intertexto inserido em material utilizado na divulgação das celebrações do oitavo centenário do país (Figura 06). Nele, lemos: "E no dia 4 de Junho de 1940, enquanto uma guerra atrós [sic] divide e dilacera a Europa e o Mundo, Portugal festejou orgulhosamente, pacìficamente, com preces, com vivas e com flores os oito séculos imortais de sua história" (FANTASIA LUSITANA, 2010, 3:19).

Ao fazermos a análise do texto acima, percebemos a presença de dois cenários bastante distintos: o primeiro é o da "guerra atroz que divide e dilacera a Europa e o mundo" e o segundo é o do Portugal como país neutro, que não participa da guerra, e que, portanto, pode "festejar orgulhosamente, pacificamente, com preces, com vivas e com flores" os oitocentos anos de sua existência. O uso da conjunção "enquanto" lembra que ambos os cenários acontecem simultaneamente. A escolha lexical que descreve o cenário da guerra, apesar de verdadeira, não oferece um olhar empático para com as nações que sofrem. O adjetivo "atroz" e os verbos "dividir" e "dilacerar" comprovam que o primeiro cenário, aquele do qual Portugal não faz parte, é o negativo e o indesejado. 


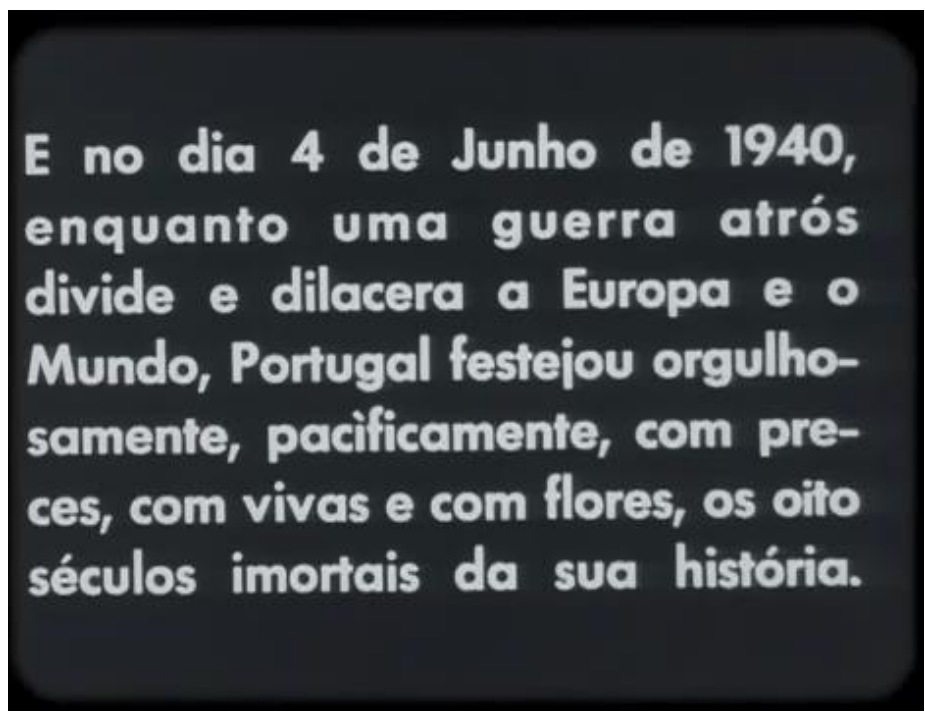

Figura 06: Intertexto que introduz imagens das comemorações do oitavo centenário de Portugal.

Por outro lado, quando examinamos o léxico escolhido para descrever o segundo cenário, percebemos a valorização que se dá a ele, e a inculcação da propaganda na mente da população. Os advérbios de modo "orgulhosamente" e "pacificamente" indicam que o país lusitano tem orgulho de viver em paz, ou seja, de ser um país "neutral".

Celebrar o oitavo centenário da nação "com preces, com vivas e com flores" patenteia alguns dos mitos ideológicos fundadores do Estado Novo aqui já discutidos. As "preces”, por sua vez, são endereçadas ao aniversário da nação, e não às populações que sofrem com a guerra. Já os "vivas" remetem à celebração em si, e as "flores", podemos supor, ao espírito simples do povo português, ligado à terra e sem grandes ambições.

Não podemos deixar de mencionar o trecho final "oito séculos imortais de sua história", onde o adjetivo "imortal" caracteriza a história de Portugal como eterna, verdadeira e inalterável, amalgamando-se num bloco único com o tempo atual. Nas palavras da pesquisadora Heloísa Paulo, "O passado retorna ao presente para constatar a continuidade da obra iniciada em 1140 e recuperada em 1640, com o fim do período filipino" (PAULO, 2011, p. 110).

Outro momento semelhante em Fantasia Lusitana ocorre quando o jornalista Fernando Pessa, que trabalhava na BBC de Londres durante o período da guerra, explica aos países neutrais, de forma bem didática, o que eram as Blitz (abreviação da palavra alemã Blitzkrieg), ou seja, ataques relâmpagos. Narrado em língua portuguesa e dirigido à população de Portugal, este excerto do filme exibe cenas de aviões lançando bombas, prédios e casas destruídos e em chamas (Figura 07), pessoas correndo em busca de abrigo 
e por fim, o desespero no rosto daqueles que sobreviveram aos bombardeios. As cenas são fortes, pois focalizam mulheres desconsoladas, um homem cego que caminha sozinho com duas bengalas por uma rua destruída (Figura 08) e muitos bebês e crianças.

No entanto, o que chama a atenção neste tipo de material "didático", é o tom jocoso utilizado pelo locutor. Vejamos a transcrição da passagem:

Blitz é uma coisa em que toda a gente fala desde 1940 nos países beligerantes e nos neutrais. Saberão, no entanto, os que vivem em países neutrais, o que de facto é uma Blitz? Talvez não. Dizemos, pois. As aflições começam sempre ao toque antipático das sereias. Depois, começa a atormentar-nos nos ouvidos o ruído dos aviões inimigos. Os ruídos são como as cerejas, um puxa o outro. E assim é que no geral se ouve logo em seguida o barulho das antiaéreas gritando cada vez mais próximo de nós: não passará! E quando passam, apressam-se a mandar cá para baixo os seus cartões de visita. Na verdade, o que melhor se ouve quando nos cai uma bomba muito perto, não é o seu estampido, mas sim o barulho dos estilhaços e vidros partidos, e casas que se vão abaixo das pernas logo que o nosso maior susto começa a passar. Há bombas de todos os tamanhos. Pode matar uma simples pessoa; pode matar sete coelhos numa só cajadada, isto é, derrubar um quarteirão de casas inteiro. É claro, a amostra ouve-se num minuto enquanto que a autêntica Blitz. se prolonga, às vezes, por uma noite inteira (FANTASIA LUSITANA, 2010, 7:10 - 9:08, grifos nossos).

Apesar da seriedade do assunto, a maneira como a narração é feita acaba por trazer um tom de comicidade ao tema. Nos intriga pensar o porquê do emprego dessa entonação, talvez para acentuar indiretamente a condição favorável de neutralidade de Portugal face ao conflito internacional. Isso se faz claro com a pergunta "Saberão, no entanto, os que vivem em países neutrais, o que de facto é uma Blitz?". Porém, é questionável a escolha do tom de escárnio na resposta.

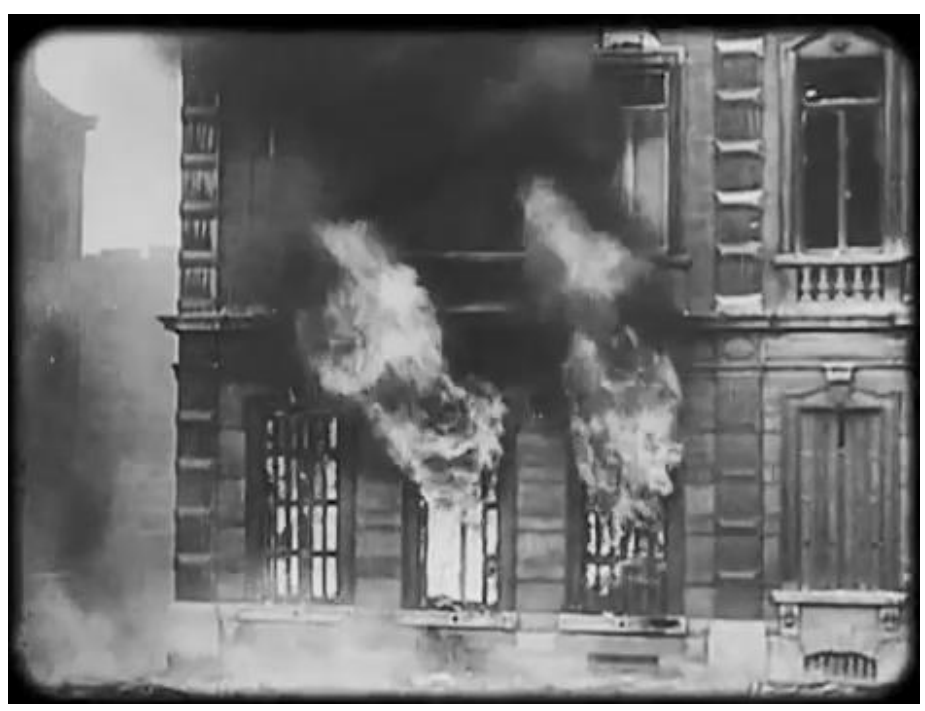

Figura 07: Edifício bombardeado em chamas durante a Segunda Guerra Mundial. 
O locutor compara o ruído dos aviões inimigos com as cerejas, isto é, "um puxa o outro". Assim como é difícil comer apenas uma cereja por ser uma fruta pequena e saborosa, os aviões inimigos que produzem os ruídos e que se aproximam com o intuito de destruir uma cidade com suas bombas também nunca vêm sozinhos. Enquanto uma grande quantidade de cerejas é algo prazeroso, o agrupamento de aviões se torna algo desesperador. Por enquanto, a comparação não chega a ser tão ofensiva, porém, não seria a mais apropriada.

O texto dá voz às antiaéreas, quando enuncia "não passará!", numa tentativa de impedir o ataque. Todavia, quando essas falham, os aviões "apressam-se a mandar cá para baixo os seus cartões de visita". Ora, relacionar as bombas, letais e destrutivas, com meros cartões de visitas chega a ser um ato de desrespeito para com as vítimas desses ataques. Não há nada de cordial ou amigável nesse tipo de abordagem.

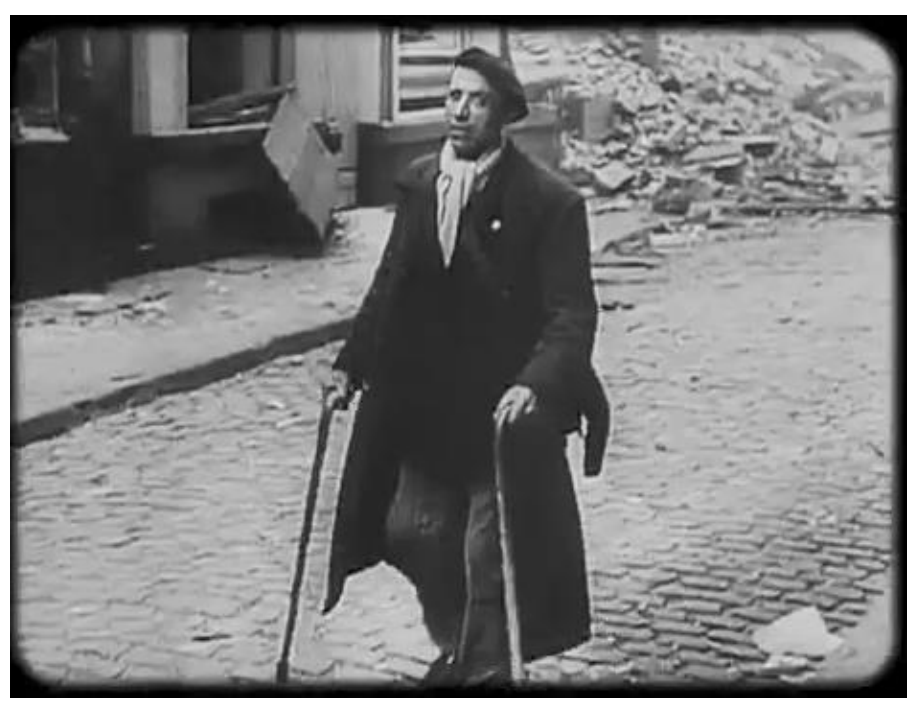

Figura 08: Homem cego caminha com duas bengalas em rua destruída por bombardeio durante a Segunda Guerra Mundial.

Por fim, ao comparar o poder de destruição das bombas, o trecho em análise adapta o ditado popular "matar dois coelhos com uma só cajadada", aumentando o número de coelhos para sete, o que revela a quantidade elevada de mortos. Em seguida, vem a explicação: “isto é, derrubar um quarteirão de casas inteiro". Por analogia, os coelhos abatidos seriam as vidas humanas tolhidas naqueles ataques aéreos. Este provérbio é usado para falar sobre uma vantagem obtida quando se espera um resultado menor do que o alcançado, isto é, com uma cajadada única espera-se matar um coelho, e quando se verifica que morrem dois, fica-se feliz com a surpresa. Ora, usá-lo para comparar com a morte de civis denota um desrespeito e falta de empatia com as vítimas. 
Diferentemente dos dias atuais, quando a informação chega imediatamente à vida das pessoas, aquelas notícias demoravam mais a chegar em terras portuguesas, e, pelo fato de o país estar blindado pela censura e influenciado pela propaganda, o tom de distanciamento usado para falar sobre a guerra era proposital. O Portugal salazarista viveu a realidade da guerra como algo que se passava muito longe, algo que não lhes dizia respeito. Salazar utilizou o fato de seu país não entrar na guerra (e nem de ser atacado) e criou o mito de que fora ele o responsável por isso, graças à sua diplomacia. Havia, portanto, um certo orgulho de não fazer parte do mundo beligerante. O ditador irá usar esse fato como trunfo quando a guerra findar na Europa em maio de 1945, conforme veremos acerca do Dia $S$ mais adiante neste estudo.

\subsection{O recrudescimento da guerra assombra Portugal}

Sabe-se que Portugal, por não ter sido partícipe direto da Segunda Guerra Mundial, não sofreu bombardeios ou invasões em seu território. Tampouco sofreu baixas em sua população civil ou militar, como a maioria dos países europeus. Dessa forma, a guerra foi sentida como algo que acontecia alhures, não obstante o risco de que a fúria bélica pudesse se voltar contra o pequeno país ibérico ou suas ilhas.

Salazar soube lidar com esse aspecto neutral de maneira arguta, sobretudo após o término do conflito. Porém, não apenas anos antes de sua eclosão - com as invasões territoriais perpetradas pelos nazistas e com a guerra civil na vizinha Espanha, por exemplo - mas durante todo o evento, fez-se necessário mostrar à população que tudo estava sob controle e que o governo tinha os meios de se proteger no caso de um eventual ataque estrangeiro. Com efeito, "O Estado tenta incutir na população a ideia de que o país possui meios militares capazes de garantirem a defesa do seu território" (BRAGA, 2005, p. 148). Dessa maneira, o regime produziu variado material propagandístico que retratava militares portugueses exibindo o seu arsenal bélico e fazendo exercícios de defesa da nação com a finalidade de demonstrar aos portugueses que o país era forte e estava preparado para quaisquer eventualidades.

Com relação a esse assunto, Heloísa Paulo lembra que "Em 1938 e 1939, assim como em todo o decorrer da Segunda Grande Guerra, quando o clima de tensão alastra na Europa, temos toda uma série de imagens dedicada às Forças Armadas e à 'segurança' militar do Estado Novo português" (PAULO, 2011, p. 105). Sendo assim, Canijo recupera 
várias dessas imagens e as incorpora em Fantasia Lusitana. A intenção do regime era provar que os portugueses estavam preparados no caso de algum ataque externo. De fato, o governo chega a investir nas Forças Armadas, tanto para tranquilizar a população quanto para alertar possíveis ameaças estrangeiras, conforme esclarece Ricardo Braga:

O medo de que a guerra ultrapassasse as fronteiras e chegasse ao território
nacional, quer ao continente, quer às regiões autónomas e colónias, levou o
Executivo a investir na modernização das Forças Armadas, não só numa
tentativa de dissuasão externa, mas também para aumentar os índices de
confiança da população que, assim, se sentiria mais segura, já que, em termos
de poderio bélico, os militares não estavam em condições de garantir a defesa
nacional (BRAGA, 2005, p. 148).

Além disso, a mensagem que se transmitia era de que a nação estava em paz graças a diplomacia de Salazar. Segue abaixo a transcrição da narração de um trecho de Fantasia Lusitana, pertencente à camada propagandística, onde são retratados, a desfilar, soldados portugueses e variados equipamentos militares de ataque e de defesa (Figura 09):

O novo exército apresentou-se de forma verdadeiramente impressionante perante milhares de pessoas que se aglomeravam na avenida. Novo fardamento, novo equipamento, novo material, novas armas, nova táctica. Produtos do espírito renovador dos seus atuais dirigentes (FANTASIA LUSITANA, 2010, 11:53 - 11:12).

A recorrência do uso do adjetivo "novo" no trecho acima serve para reforçar a ideia de que o Exército Português àquela altura tinha se modernizado, logo, estava apto a combater e a defender seu país eficazmente em caso de necessidade. É importante notar que a parada militar se dava perante "milhares de pessoas que se aglomeravam na avenida", isto é, para que houvesse resultados, era premissa do regime haver público, quer presente ao evento em si, quer nas salas de cinema, onde o material propagandístico seria exibido. Agora, chamamos a atenção para o fato de que a propaganda está sempre glorificando e exaltando os líderes do governo, seja na figura dos membros do então Ministério da Guerra, parte integrante do Estado Novo, seja na figura dos Chefes da Nação, como no excerto acima, que atribui a modernização militar ao "espírito renovador dos seus atuais dirigentes". 


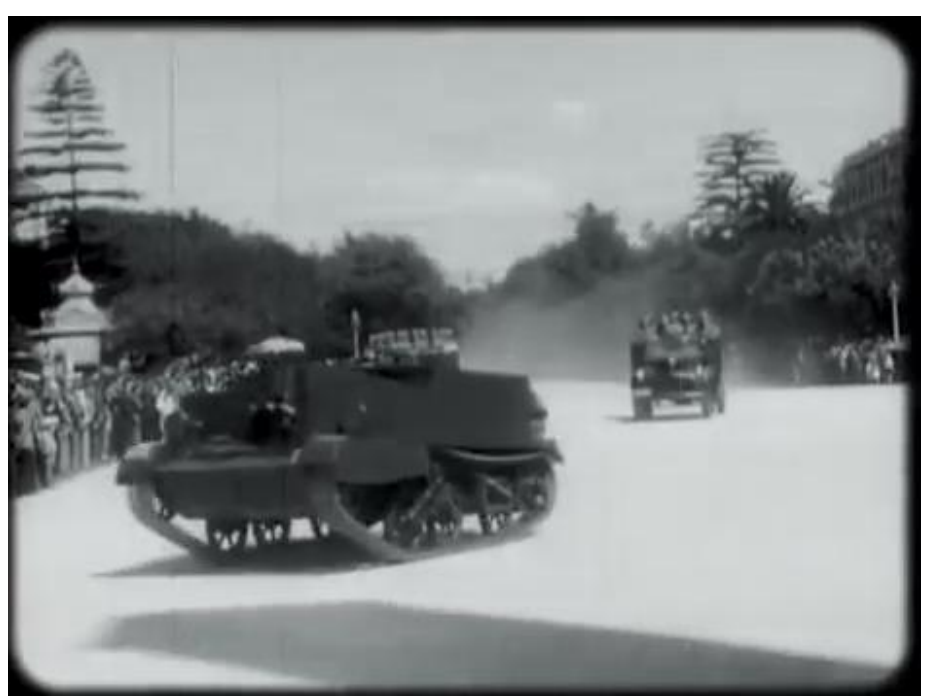

Figura 09: Fotograma de Fantasia Lusitana: O exército português exibe o seu arsenal militar.

Um capítulo que marcou Portugal na Segunda Guerra Mundial de forma profunda foi a questão dos Açores, dada a sua posição geográfica estratégica. "Sucessivamente ameaçado de ocupação por ingleses, americanos e alemães, o arquipélago do Açores foi sempre uma das preocupações do salazarismo" (BRAGA, 2005, p. 150). Para que compreendamos melhor o papel que esse arquipélago desempenhou (ou poderia vir a desempenhar) é necessário aprofundarmos nesta questão. Ricardo Braga explica que

\footnotetext{
No final de 1940, Salazar chega mesmo a iniciar negociações com a Inglaterra para assegurar o apoio e a protecção dos ingleses na eventualidade de um ataque alemão ou espanhol. Tratava-se da criação de um plano de retirada do governo português para os Açores e a posterior defesa do arquipélago (BRAGA, 2005, p. 148).
}

Portugal, aliado centenário da Inglaterra, conta com o suporte e a proteção ingleses no caso de um eventual ataque estrangeiro. Por outro lado, por se encontrarem em guerra, os planos britânicos parecem não atender às expectativas portuguesas. É o que esclarece Tiago Tadeu: "O ano de 1941 acabou por ser de grande tensão para a diplomacia portuguesa, confrontada com um eventual plano britânico ou norte-americano para a invasão de Portugal, ou, pelo menos, dos Açores, como resposta a um hipotético ataque do III Reich" (TADEU, 2011, p. 16).

Esta possível investida se deveu ao clima de desconfiança por parte dos Aliados em relação à administração de Salazar, que, não obstante a aliança secular com o Reino Unido, se aproximava ideologicamente do governo de Francisco Franco, vencedor da Guerra Civil Espanhola com o apoio da Itália e da Alemanha. Com o passar do tempo, e, com a mudança do curso da guerra, o receio dos aliados nesse sentido arrefeceu. 
Mais tarde, as ilhas açorianas passaram a ser requisitadas pelos Aliados para a construção de bases militares, recebendo, no início, a negativa de Salazar. Entretanto, com a intensificação das pressões nesse sentido, o Chefe de Estado português não teve outra opção senão ceder. Segundo Tadeu,

Estas ilhas adjacentes tinham uma importância geoestratégica devido ao papel
nuclear que desempenharam no apoio aos sistemas de comunicação, tráfego
marítimo e aéreo entre as duas margens do Atlântico. Tal foi a razão que levou
o Reino Unido e os E.U.A. a solicitar em 1943 ao Governo português, a
construção de instalações miliares nos Açores (TADEU, 2011, p. 16).

Em decorrência do constante constrangimento sofrido por Portugal referente à suas ilhas, foram enviados contingentes militares até aquele arquipélago, a fim de assegurar a soberania portuguesa. Nesse sentido, a propaganda do regime produziu documentários para mostrar à população que os Açores permaneceriam portugueses, mostrando a bravura dos soldados e o apoio de suas famílias.

Fantasia Lusitana resgata um desses materiais, onde vemos soldados portugueses embarcando no navio "Carvalho Araújo" com destino ao arquipélago, enquanto seus familiares e amigos acenam em despedida desde o cais (Figura 10). Vejamos a transcrição do trecho em questão:

Em pleno uso do seu direito de soberania e em defesa de sua rigorosa posição de neutralidade perante a guerra actual, o governo português continua a enviar para os Açores contingentes de tropas admiravelmente preparadas e equipadas. A bordo, os soldados que partiam, e em terra, as suas famílias e amigos, todos os que ali estavam a despedir-se, conhecidos ou não, eram amigos. No momento emocionante da largada só tinham um pensamento, a independência da pátria, aquém e além-mar (FANTASIA LUSITANA, 2010, 10:59 - 11:35).

O texto acima engloba vários dos ideais do Estado Novo, uma vez que foi produzido pela propaganda salazarista. Em primeiro lugar, vemos que o status de neutralidade de Portugal é reforçado: "em defesa de sua rigorosa posição de neutralidade perante a guerra atual”. Em seguida, o locutor enaltece as tropas portuguesas, informando que estão "admiravelmente preparadas e equipadas", embora, se comparadas a seus pares britânicos, americanos, italianos ou alemães, o grau de preparação e a qualidade dos equipamentos seria bastante inferior. 


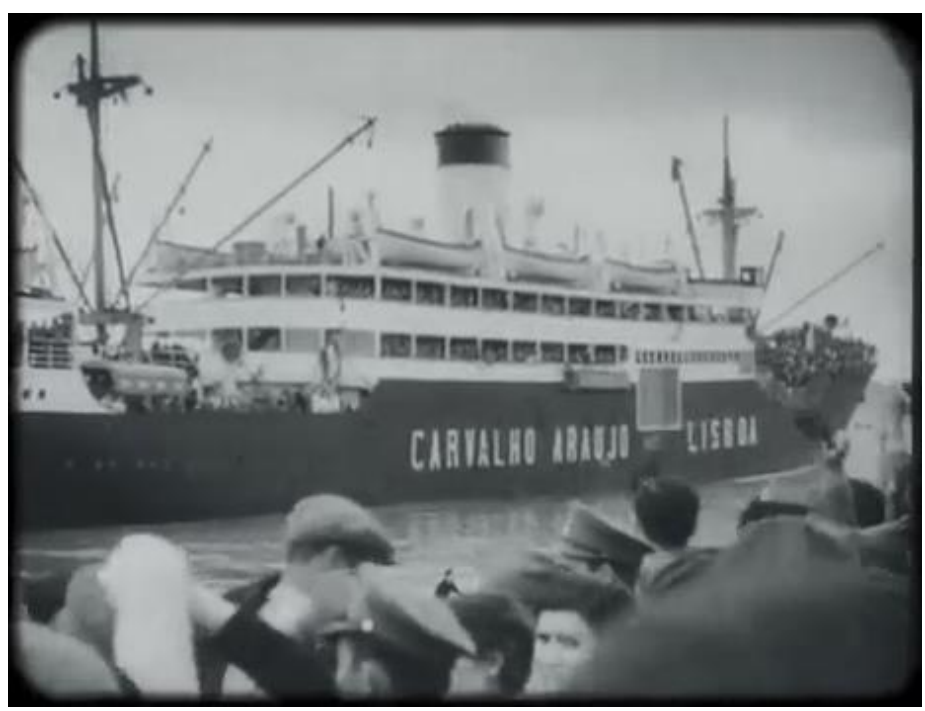

Figura 10: Familiares e amigos se despedem dos soldados portugueses que se dirigem rumo aos Açores no navio Carvalho Araújo.

Por último, o conteúdo procura transmitir à população que os interesses da nação vêm antes dos interesses familiares, em consonância com os mitos ideológicos fundadores do Estado Novo. Ao observar a cena de despedida entre soldados e familiares, vemos, tanto em terra quanto na embarcação, mãos que acenam, muitas delas com lenços brancos, e ouvimos a voz do locutor a dizer: "todos os que ali estavam a despedir-se, conhecidos ou não, eram amigos". Dessa forma, a ideologia vigente no governo pretende provar que havia apoio irrestrito por parte das massas, uma vez que estavam todos ali irmanados por um sentimento de amizade. E, para não haver dúvidas, a voz da propaganda enuncia que os presentes ali reunidos "só tinham um pensamento, a independência da pátria, aquém e além-mar”, o que reforça a ideia de que a entidade Portugal está acima dos interesses individuais.

\subsection{A "neutralidade" e a "diplomacia" portuguesas}

Antes de tudo, é importante contextualizar o cenário neutral e não beligerante da Europa durante o período da Segunda Guerra Mundial. O pesquisador Vítor de Sousa explica que "Portugal, a par da Suíça e da Turquia, tinham o estatuto de neutralidade, enquanto a Espanha assumia um estatuto diferente, de não-beligerância” (SOUSA, 2013, p. 624). Uma vez definido este quadro, lembramos que Fantasia Lusitana trabalha com a questão de como a propaganda salazarista explorou a condição de neutralidade portuguesa durante os anos de conflito. O material fílmico propagandístico original, recuperado pelo documentário de João Canijo, estava sempre a lembrar que o Estado 
Novo conseguia navegar bem por ambas as polaridades envolvidas, ou seja, mantinha boas relações com os Aliados bem como com os países do Eixo, além da Espanha, que apesar de ter status de não beligerância, compartilhava de ideologia fascista semelhante.

No entanto, a informação de que Portugal era fornecedor de volfrâmio (mineral utilizado na indústria de munições, também conhecido por tungstênio) a países pertencentes a ambos os lados do conflito não era mencionada pela propaganda. A respeito desse comércio, Tiago Tadeu explica que:

\begin{abstract}
O tungsténio era importante para o esforço de guerra alemão e foi alvo de uma acesa disputa entre o III Reich e os Aliados (ingleses e norte-americanos). Estes últimos, apesar de disporem de outras fontes de fornecimento, competiam pelo minério português com o intuito de dificultar e, mais tarde evitar o acesso dos alemães ao mesmo. O volfrâmio português [...] ganhou um interesse mais relevante para os alemães a partir de Junho de 1941, altura em que foi lançado o ataque à U.R.S.S. e que deixou de ser possível poder contar com os fornecimentos oriundos da China transportados através do território soviético (TADEU, 2011, p. 16).
\end{abstract}

Uma vez que a indústria armamentista dos países beligerantes era alimentada, em parte, pelas exportações do volfrâmio português, não seria interessante para a propaganda estatal que essa informação fosse divulgada abertamente, pois ameaçaria a construção da imagem de neutralidade de Portugal. Assim, fazia parte dos planos propagandísticos veicular uma imagem imparcial do país. A partir dos $15 \mathrm{~min} 39 \mathrm{~s}$, o espectador de Fantasia Lusitana é exposto à uma sequência de trechos de pouco mais de três minutos, oriundos de informativos produzidos pela propaganda, ora com a banda sonora original onde se ouve a voz do locutor, ora com a voz de Salazar lendo seus discursos. Estes intertextos trazem informações acerca de visitas militares estrangeiras ocorridas em Portugal pertencentes a lados opostos do conflito, que, segundo a propaganda, ocorria graças à neutralidade portuguesa:

- “A visita do "DEUTSCHLAND"” (FANTASIA LUSITANA, 2010, 15:39), onde se vê a suástica nazista abaixo dos dizeres e, à esquerda, o desenho de um navio;

- “A visita oficial da "HOME FLEET"” (FANTASIA LUSITANA, 2010, 16:24), em cujo fundo há a imagem da bandeira da Marinha Real Britânica;

- “A 8 a Divisão Naval Italiana em Lisboa” (FANTASIA LUSITANA, 2010, 16:49), com o desenho de três navios de guerra;

- “Os falangistas espanhóis em Lisboa” (FANTASIA LUSITANA, 2010, 18:24), com o símbolo dos falangistas representado pelo feixe de cinco flechas. 
Ao condensar em um pequeno excerto as visitas militares desses países antagonistas em terras portuguesas, a montagem de Fantasia Lusitana proporciona que a ideologia salazarista se apresente ao público contemporâneo, revelando quão contraditória ela era.

Salazar incutia a ideia de que Portugal se mantinha neutro durante a guerra graças à sua política governamental. Em Fantasia Lusitana, há um trecho onde vemos um cortejo de veículos, acompanhado pela cavalaria nacional, levando representantes de vários governos até um edifício. Há um título onde lê-se "A recepção das Embaixadas Especiais no Palácio da Ajuda" (FANTASIA LUSITANA, 2010, 14:29). Lá dentro, esses representantes se aproximam do Presidente da República, o cumprimentam, entregam uma folha de papel em suas mãos, a qual é entregue a Salazar que se encontra mais atrás. Entretanto, devido à montagem, o que se ouve no início é um dos discursos de Salazar lido em sua própria voz, conforme a transcrição abaixo:

São certamente grandes as dificuldades dos tempos. E ninguém sabe, neste acanhado mundo, qual a parte de sofrimentos que lhe reserva direta ou indiretamente a tragédia da Europa. Temos conseguido e, digamos, merecido, viver em tranquilidade na península. E temos a certeza de que nos acompanham na nossa conduta, a simpatia e solidariedade moral de muitos povos, não seguramente pelo egoísmo duma atitude, mas pelo real valor europeu duma política (FANTASIA LUSITANA, 2010, 14:29 - 15:09, grifos nossos).

Por trás deste discurso, o chefe do governo afirma que, não obstante a guerra em curso, Portugal tem "conseguido" e "merecido" viver em paz graças à sua conduta e à simpatia por parte das outras nações devido ao valor de sua política. Isto é, Salazar assume o papel de grande negociador e pacifista durante o conflito mundial, uma vez que a propaganda trabalha para construir esta imagem. Quando a narração original da filmagem é retomada, o locutor enuncia:

\footnotetext{
Mais nenhum país poderia permitir-se hoje a honra de reunir na mesma sala, lado a lado, representantes de nações agora inimigas entre si. Maravilhoso prêmio duma política de verdade, de lealdade e de firmeza, que bastaria para imortalizar a figura de Salazar como Ministro dos Negócios Estrangeiros (FANTASIA LUSITANA, 2010, 15:09 - 15:37).
}

O nível propagandístico de Fantasia Lusitana ressuscita o que foi a ideologia salazarista, contextualizando-a para o espectador do século XXI. Temos a construção da narrativa a informar que a "política de verdade, de lealdade e de firmeza" de Portugal imortalizou "a figura de Salazar" pelo fato de ter reunido no mesmo ambiente "representantes de nações agora inimigas entre si". A diplomacia portuguesa, através de 
seus líderes, sempre foi explorada pela propaganda salazarista, embora seja de conhecimento geral que, na realidade, Portugal sempre foi dependente econômica e financeiramente das nações mais ricas e poderosas. Ademais, a neutralidade portuguesa durante a guerra era interessante para ambos os lados do conflito, conforme anota Vítor de Sousa: “[...] tratou-se de uma situação que decorreu de uma conjugação de alguns fatores, tendo sido boa para a Alemanha (que vinha buscar volfrâmio a Portugal), e para os ingleses (que assim podiam fazer passar refugiados pela Península Ibérica)" (SOUSA, 2013, p. 625).

Ainda sobre a construção propagandística da diplomacia portuguesa, há um pequeno trecho que aborda a troca de cidadãos de nações pertencentes a lado opostos do conflito em terras portuguesas. A passagem começa com o título "Troca de beligerantes em Lisboa" (FANTASIA LUSITANA, 2010, 17:04) e mostra imagens de passageiros desembarcando. O locutor informa que "Graças à intocável neutralidade portuguesa, pôde efetuar-se em Lisboa a troca entre cento e dois súbditos alemães e vinte e sete cidadãos brasileiros que se encontravam detidos nos campos beligerantes contrários" (FANTASIA LUSITANA, 2010, 17:04 - 17:19)

Portugal é construído pela máquina da propaganda para ser a nação diplomata por excelência, ou seja, um país conciliador - ideia inculcada na mente da população constantemente através dos meios de comunicação (Figura 11). O adjetivo "intocável", utilizado para descrever a neutralidade portuguesa, revela uma condição de integridade, isto é, condição merecedora de respeito, acentuando características positivas.

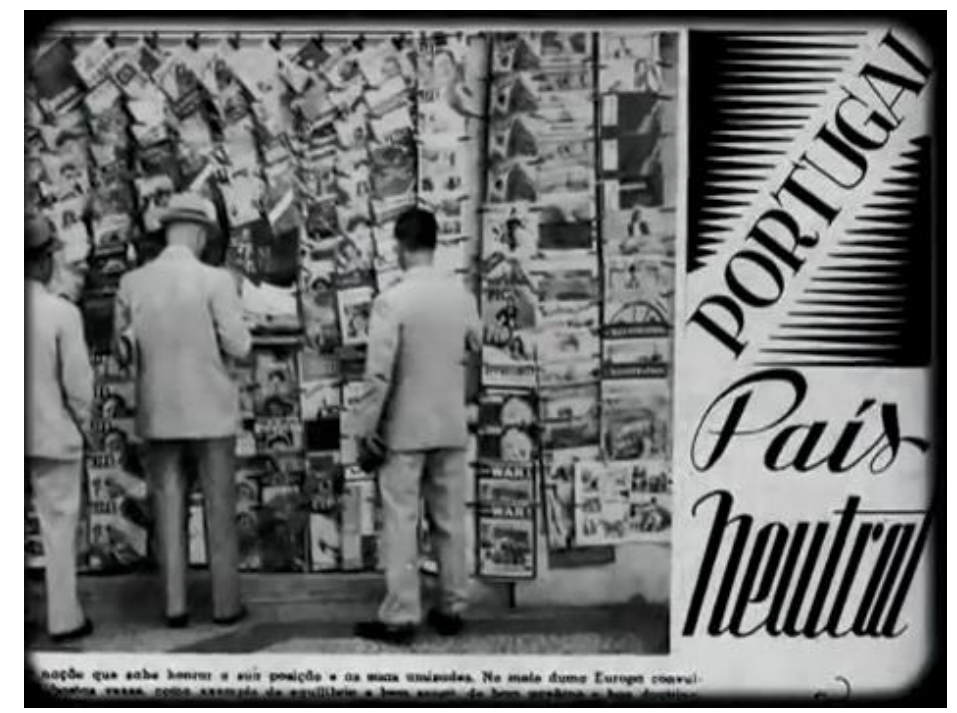

Figura 11: Fotograma de Fantasia Lusitana que relembra a neutralidade de Portugal durante a Segunda Guerra Mundial. 
Em outro trecho do documentário, quando se ouve a voz de Salazar lendo um de seus discursos, o ditador conclama a união dos portugueses:

No trabalho ou nos sacrifícios, no sofrimento ou na caridade, nas alegrias ou
nas preocupações da vida individual e coletiva, fomos guiados e salvos, pelo o
amor pátrio, a reencontrar o elo de solidariedade, que devia prender-nos como
as pedras do edifício a sermos finalmente perante o mundo, todos como um só
(FANTASIA LUSITANA, 2010, 10:30 - 10:58).

Ao bradar que os cidadãos deveriam unir-se "como as pedras do edifício", ou seja, serem "todos como um só", o Chefe da Nação relembra que a motivação desta união deve ser o "amor pátrio", que, segundo a ideologia do Estado Novo, deveria vir sempre em primeiro lugar.

Ainda dentro da construção da imagem de Salazar como o responsável pela neutralidade de Portugal durante a guerra, transcrevemos uma canção de exaltação à sua figura presente no documentário de João Canijo. Esta cantiga é cantada por vozes masculinas, e tem um tom bastante lento e taciturno, lembrando a melancolia do fado ou o ritmo dos cantos religiosos, aproximando-se de um tom de lamento. Entretanto, a letra desta cantiga traz uma pequena narrativa acerca do líder do Estado Novo:

Salazar foi o primeiro que não quis na guerra entrar.

Nem mandar p'ra o estrangeiro suas tropas a lutar.

Excelente homem, conseguiu o que ele quis.

Manteve a ordem cá dentro do seu país.

Cá dentro do seu país, onde tanta gente há.

Para não ser desordeiro, queremos viver em paz.

Chefe da Nação, como el'outro não há.

Lutaremos todos para salvar Portugal.

Chefe da Nação, como el'outro não há.

Viva o Senhor Doutor Oliveira Salazar!

(FANTASIA LUSITANA, 2010, 12:33 - 14:27).

Nela, há a narrativa de que Salazar foi o primeiro dos líderes que optou por não entrar na guerra, logo, não existindo a necessidade de enviar tropas ao estrangeiro. Já aqui, nota-se o líder como alguém que se aproxima da figura de um pai protetor que preza pela paz e que se preocupa com a integridade de seu povo. Em seguida, a letra da canção retrata Salazar como um homem excelente, que conseguiu manter a ordem dentro de Portugal, um país com tanta gente - mais uma vez reforçando a ideia de que o estadista é um homem preparado e que se preocupa com as vidas dos portugueses.

As vozes soturnas então afirmam que não há outro como Salazar, colocando-o na posição de o único responsável por governar os portugueses e de manter a paz no país, corroborando o mito da ordem corporativa, como definido por Rosas. Depois, as vozes 
que representam o coletivo dos portugueses prometem lutar para salvar Portugal, reconhecem novamente que não há outro líder como o deles, e terminam por lançar vivas ao ditador.

Enquanto o espectador ouve a canção transcrita acima, são exibidas as seguintes imagens: apresentação de equipamentos militares, soldados marchando, o intertexto com os dizeres "Os preparativos para os exercícios de defesa contra ataques aereos em Lisboa" (FANTASIA LUSITANA, 2010, 12:53), e, a partir de então, fotografias de militares provavelmente extraídas de jornal ou revista, com as seguintes legendas: “As peças antiaéreas postadas no Parque Eduardo VII", "Na serra de Monsanto, uma metralhadora antiaérea procura alvejar um avião", "JÁ HÁ DIAS que todos os prédios de Lisboa têm colocados nas janelas as tiras protectoras de papel para evitar a queda dos vidros estilhaçados. Aqui vemos um edifício da Baixa com todas as janelas e portas protegidas" e "Uma patrulha da "Legião Portuguesa" percorrendo a cidade", todas as imagens fotográficas mostrando que o governo se preparava para defender Portugal da possibilidade de um ataque.

Dessa forma, este capítulo procurou abordar de que maneira a propaganda salazarista se esforçou por criar a imagem de Salazar como um líder pacifista, influente e precavido. Canijo inicia seu documentário apresentando ao espectador esse mundo fantasioso, criado artificialmente para exaltar o Estado Novo, sua política e seus ministros, com destaque para o ditador. É importante ressaltar que tal tônica representa apenas uma camada do documentário, que passará a se intercalar com outras óticas e pontos de vista conforme veremos adiante. 


\section{CAPÍTULO 2: A CONTESTAÇÃO DA FANTASIA}

Como havíamos explanado anteriormente, Fantasia Lusitana possui dois níveis (ou camadas) principais de realidade, isto é, o primeiro referindo-se àquele da propaganda salazarista, o qual temos abordado até agora, e o segundo, contrastando com o primeiro, apresenta o ponto de vista dos três refugiados que passaram por Lisboa em 1940, cujas apresentações foram feitas na introdução desta dissertação, e que, pelo fato de terem vivenciado o cenário da guerra, conseguem, com o olhar isento da fantasia propagandística, perceber, de maneira mais lúcida, o país que os hospeda.

Antes de iniciarmos a análise do ponto de vista estrangeiro destes três intelectuais, faz-se importante recordar que, de certa forma, o nível da realidade bélica já havia sido tocado pelo documentário quando imagens da Alemanha nazista foram exibidas. Essas imagens eram acompanhadas da explicação do jornalista Fernando Pessa sobre o que eram as Blitz, com imagens de bombardeios aéreos, prédios em chamas e sobreviventes desesperados (incluindo bebês e crianças) tentando fugir daquele cenário infernal. Embora as imagens apresentassem cenas da guerra, a narração, altamente caracterizada pelo tom chistoso, pertencia ao nível da propaganda, uma vez que foi criada e direcionada à população portuguesa pelos órgãos estatais.

Dessa forma, podemos dizer que a esfera que patenteia o ponto de vista de quem conheceu a guerra de perto começa efetivamente com os depoimentos desses três refugiados ilustres. Em vista disso, colocamos abaixo as indicações referentes aos textos de onde foram extraídos os excertos utilizados no documentário de Canijo, conforme os créditos finais da película:

- Alfred Döblin, "Portugal", in "Schicksalsreise" (1949) - texto traduzido para a língua portuguesa por Claudia J. Fischer;

- Erika Mann, "In Lissabon Gestrandet", in "Ausgerechnet Ich: Ein Lesebuch" (194?) - texto traduzido para a língua portuguesa por Claudia J. Fischer;

- Antoine de Saint-Exupéry, "Lisbonne Jouait au Bonheur", in "Lettre à un otage" (1944) - texto traduzido para a língua portuguesa por António Rodrigues.

Esses textos são autobiográficos e retratam as memórias desses refugiados acerca de suas passagens por Lisboa a fim de fugirem das atrocidades da guerra. Os três passaram 
por Lisboa no ano de 1940, sendo que Döblin e Mann estiveram na capital portuguesa no mês de outubro, ao passo que Saint-Exupéry transitou por lá em dezembro.

Sabe-se que milhares de estrangeiros utilizaram o porto de Lisboa como rota de fuga durante a Segunda Guerra Mundial graças à condição de neutralidade de Portugal, atribuída por muitos à política de Salazar. Canijo, entretanto, em entrevista a Ana Margarida de Carvalho, do portal de conteúdo Visão, contesta esta versão. Para o cineasta, "A história da neutralidade é um mito, outra fantasia, não foi obra de Salazar, antes uma realização muito habilidosa das forças beligerantes a quem dava um jeitaço ter um porto neutral na Europa" (CARVALHO, 2010). De qualquer forma, esses refugiados somente poderiam fazer uso da rota portuguesa para deixar a Europa desde que obtivessem vistos de ingresso e que provassem que tinham passagens compradas para o exterior. Por esse motivo, entre a admissão em Portugal e o embarque no navio que os tiraria da Europa, havia sempre um período de espera, que oscilava entre vários dias até algumas semanas, dado que a fuga por meio deste expediente era muito procurada.

Portanto, 1940 acaba sendo um ano muito relevante neste documentário, pois, além de estar relacionado à passagem dessas três testemunhas por Portugal, também é o ano em que se comemorou um Duplo Centenário, ou seja, o aniversário de oitocentos anos da fundação do Estado Português, em 1140, e os trezentos anos da restauração da independência do jugo filipino, em 1640. São justamente essas duas festividades que motivarão a inauguração da Exposição do Mundo Português no segundo semestre do referido ano, cuja temática também se encontra presente em Fantasia Lusitana.

Receber refugiados de uma guerra que acontecia muito próximo dali ao mesmo tempo em que o país, despreocupadamente, festejava suas efemérides, acaba por revelar duas faces contraditórias do mesmo país. A esse respeito, a pesquisadora Heloísa Paulo recorda que, "Em 1940, afirmando a 'neutralidade' do regime e a tranquilidade do País, as cenas das Comemorações do Duplo Centenário traduzem a ideia de um 'mundo à parte' numa Europa em guerra" (PAULO, 2011, p. 105). Em outras palavras, este espaço apartado do resto da Europa gera uma condição de isolamento não apenas geográfico uma sensação de não pertencimento - mas, sobretudo, um alheamento agravado pela ideologia da propaganda salazarista. Tal condição gerou um mal-estar nos estrangeiros que procuraram refúgio temporário em terras portuguesas, conforme veremos nas anotações de Döblin, Mann e Saint-Exupéry. 
A partir do momento em que a palavra é dada a esses estrangeiros para relatar suas impressões referentes a Portugal, é que os dois níveis que permeiam Fantasia Lusitana começam a se entrelaçar, causando estranhamento. $\mathrm{O}$ espectador, ora tem acesso às imagens e aos sons originais conforme foram exibidos na década de 1940, ora acessa as opiniões dos refugiados pelas vozes dos atores nos idiomas originais dessas testemunhas. Essa técnica de montagem evidencia um abalo na camada propagandística uma vez que a ideologia salazarista passa a ser questionada. Por agora, para efeito de análise apenas dessas memórias, decidimos manter os três testemunhos separados e contínuos, e não da forma fragmentária proposta pela montagem, que será analisada posteriormente.

\subsection{Alfred Döblin}

É, portanto, aos 19min03s, isto é, praticamente depois de um terço do decorrer do documentário, que sucede a primeira intervenção estrangeira no mundo da fantasiosa propaganda. Nos referimos à primeira vez em que ouvimos o ator Rüdiger Vogler, que dá voz às memórias do escritor e médico judeu-alemão Alfred Döblin, consagrado pelo seu romance Berlin Alexanderplatz (1929).

O literato inicia a sua fala relatando a tristeza e o desânimo que o acometeram com a viagem forçada até Portugal. O seu estado de ânimo era de tal forma apático que ele chega a questionar se tivera viajado, cogitando que aquela jornada pudesse ter sido um sonho. Então, o médico judeu revela o sentimento de derrota que sentia, oriundo dos sofrimentos gerados pela guerra. Até aqui, temos o relato de uma pessoa que tinha vivenciado e sofrido as perseguições daquele conflito, o que o difere da maioria dos cidadãos portugueses que conheciam da guerra apenas aquilo que a censura permitia e o que a propaganda divulgava.

É então que o escritor tece as primeiras impressões de Portugal, descrito como "um mundo colorido, meridional e pacífico" (FANTASIA LUSITANA, 2010, 20:09). O que chama a sua atenção na cidade é o seu clima (calor), a sua claridade (ruas iluminadas, luzes) o seu barulho (música, risos, cantos, baile, campainhas, chiados e buzinas) e as pessoas (multidão de gente animada, pessoas que cantam). Não obstante o ambiente alegre e festivo observado desde o seu quarto de hotel, o autor de Berlin Alexanderplatz. não consegue se sentir feliz por se encontrar em um país livre. Este contraste de realidades faz com que Döblin fique espantado: “Que mundo. Que mundo! Inacreditável. Nunca 
esqueceremos o impacto que isto teve em nós" (FANTASIA LUSITANA, 2010, 20:48 21:00).

Ao perceber a discrepância dos dois cenários, o médico alemão volta imediatamente o seu pensamento à experiência bélica recém-vivida, e reflete:

Não longe daqui a grande nação francesa contorcia-se de dor. Cidades inteiras
mergulhadas na obscuridade da guerra. O norte do país inundado de
conquistadores. Passava-se fome e aguardavam-se ordens do invasor. Sofria-
se e estava-se prostrado. Milhões de homens levados para cativeiro, milhões
de pessoas aterrorizadas, dezenas de milhares de mortos - e aqui, em Lisboa
as luzes brilhavam. Desfrutava-se a paz. Mas nós não conseguíamos sentir
alegria. Só pensávamos no que deixamos para trás. Irrequietos, dirigimo-nos
de carro para a cidade do brilho, de um brilho que se nos parecia infernal
(FANTASIA LUSITANA, 2010, 21:01 - 21:48).

O excerto acima retoma o cenário conhecido de guerra (ocupação da França, cidades escuras, invasões, fome, sofrimento, prostração, cativeiro, terror, morte) e em seguida recorda a realidade portuguesa, tão oposto ao cenário europeu marcado pelo conflito. $\mathrm{O}$ fato de descobrir uma Lisboa alegre e festiva, apesar da guerra em curso, faz com que o intelectual fique incomodado e sinta empatia pelas vítimas da guerra: "[...] nós não conseguíamos sentir alegria. Só pensávamos no que deixamos para trás”. Por isso, para ele, a paz de Lisboa era triste. Esta confissão retrata o olhar do forasteiro que, abalroado pela emoção, consegue individuar a indiferença sentida por Portugal em relação ao conflito ou aos refugiados, indiferença esta ampliada pela propaganda veiculada pelo Estado Novo, haja vista a explicação aos portugueses do que eram as Blitz.

É apenas aos 39min07s que o relato de Döblin retorna ao documentário. O exilado menciona o calor fora do padrão considerado "nada normal", mesmo em Lisboa. É justamente esse aspecto que fará com que o escritor se questione: "Onde é que estava o normal? Que saudades que tínhamos do normal" (FANTASIA LUSITANA, 2010, 39:24 -39:32), referindo-se à vida habitual que todos tinham antes da eclosão da guerra.

A partir de então, começa a emitir juízo de valor acerca do país que o hospedava, elencando estereótipos comuns que os europeus do Norte geralmente têm acerca dos europeus do Sul:

Se agora me pedissem para falar de uma coisa muito elementar em Lisboa para além do calor terrível, do ar ardente nunca antes sentido, terei de mencionar o ruído. A cidade de Lisboa é uma cidade meridional carregada de ingenuidade e sensualidade - até mesmo na desinibição da sua gente - própria de uma criatura subtropical. Lisboa é, usando termos industriais, uma fábrica moderna para a produção de ruído (FANTASIA LUSITANA, 2010, 39:33 - 40:04). 
Além de se espantar com o clima quente da capital portuguesa, o refugiado destaca o barulho causado pela cidade e seus habitantes, passando a julgá-los como seres "ingênuos, sensuais e desinibidos" - características de "criaturas subtropicais". Embora estivesse na condição desfavorável de fugitivo dos nazistas, Döblin não poupa os hábitos considerados por ele como exóticos nos portugueses, chamando Lisboa de "fábrica moderna para a produção de ruído".

No entanto, somente aos $42 \min 17 \mathrm{~s}$ é que iremos descobrir outra faceta deste ruído. Não se trata apenas do burburinho das pessoas nas ruas ou nos bailes, ou dos sons produzido pelos bondes, já descritos pelo médico. Ele se refere ao hábito dos portugueses de cuspirem em público sem motivo:

Cospe-se em Lisboa. Não, não me enganei. Foi isto mesmo que eu quis dizer. É um fenômeno natural. Todos o fazem, novos e velhos, homens e mulheres, civis e militares. Cospem mesmo sem ter pastilha elástica, digamos que o fazem sem razão aparente, assim, sem mais nem menos (FANTASIA LUSITANA, 2010, 42:17 - 42:40).

Mais uma vez, o olhar do europeu do norte está a julgar aquele comportamento então comum entre os portugueses daquele tempo. Döblin se surpreende ao perceber que este costume é praticado pela população local indistintamente, não se tratando de uma questão de geração, de gênero ou de condição de civil ou militar. O que o intriga é o fato de este fenômeno acontecer em público de forma natural, sem pudor, e não motivado por uma razão política ou forma de protesto. Para ele, haveria uma justificativa se Portugal fosse um país ocupado, como a Holanda ou a Noruega, mas não era o caso, dada a sua condição de neutralidade. Não obstante, Döblin parece ignorar que os portugueses viviam sob uma ditadura, padeciam dos males presentes em um país pobre e pouco desenvolvido, eram recenseados, censurados e sofriam com a influência da doutrinação ideológica do Estado Novo, em suma, viviam sob um governo opressor.

Ao ser incapaz de encontrar uma razão lógica a respeito deste hábito português, o médico propõe a sua própria teoria: "Precisamos de uma explicação e encontramo-la no ruído. O cuspir e o ruído são parte do mesmo. Como não podem gritar continuamente e como nem todos dispõem de um badalo, cospe-se, manifestando, como tal, pelo menos uma boa vontade" (FANTASIA LUSITANA, 2010, 43:04 - 43:20). Embora não seja tão claro, este comentário leva à associação do cuspir com o ruído (não apenas os ruídos da cidade, mas também o ruído produzido pelo ato de expelir), já que, para ele, são partes integrantes do mesmo processo. Obviamente, o hábito de cuspir em público reforça a 
ideia de pouca civilidade por parte da população portuguesa, acentuando o estereótipo comum entre os países do norte da Europa. Além disso, a tradução presente na legenda e a entonação do ator levam à ideia de que talvez haja um menosprezo compensatório diante da indiferença dos portugueses em relação à violência vivenciada pela população dos países em guerra.

Alfred Döblin, originário da chamada "Europa civilizada", tem uma visão preconceituosa dos portugueses. Esta visão está em consonância com os estudos de Boaventura de Sousa Santos acerca da percepção de Portugal pelos norte-europeus. Segundo Santos, esta visão vai “do subdesenvolvimento à precariedade das condições de vida, da indolência à sensualidade, da violência à afabilidade, da falta de higiene à ignorância, da superstição à irracionalidade" (SANTOS, 2003, p. 30). De certa forma, ao selecionar estes excertos das memórias de Döblin para Fantasia Lusitana, Canijo não apenas desconstrói o Portugal perfeito criado pela propaganda salazarista (sem, contudo, ter a intenção de ridicularizar seus conterrâneos), mas também denuncia o preconceito presente nos europeus do norte (verbalizado por Döblin), que acabam por criar uma espécie de "fantasia estrangeira" em relação aos habitantes do sul do continente.

O próximo trecho do testemunho do médico alemão, aos $46 \mathrm{~min} 49 \mathrm{~s}$, retrata a desagregação familiar causada pela guerra. O refugiado explica que

A esquina da posta-restante em Lisboa, em Portugal, no canto mais remoto da Europa, tornou-se no ponto de encontro trágico para muita gente neste ano da desgraça de 1940 que pôs a nu a frivolidade e a inconsciência de uma vida aparentemente tranquila na Europa (FANTASIA LUSITANA, 2010, 46:49 47:10).

A posta-restante era um sistema de envio de correspondências que não eram entregues no endereço do destinatário, permanecendo nos correios até que o interessado fosse até lá para retirá-las. Este procedimento é completamente aplicável àquela situação de precariedade, na qual milhares de refugiados se encontravam em Lisboa sem notícias de seus familiares e sem endereço fixo.

Em seguida, ele testemunha a aflição e a incerteza que tomavam conta daquelas pessoas, na busca de obtenção de notícias de seus familiares:

\footnotetext{
Alguns esperavam notícias da família que ficara em França ou Espanha. Outros procuravam os seus já em Lisboa. Aqui se punham em brigadas, em fileiras, os fugitivos, os náufragos, e perguntavam por cartas e telegramas. Na sua maioria eram homens e mulheres bem vestidos que traziam nos rostos e nos movimentos os sinais do seu destino: a inquietação baça e a tensão (FANTASIA LUSITANA, 2010, 47:35 - 48:06).
} 
Pelo fato de os refugiados terem sido obrigados a deixar os seus lares, consequentemente, interrompendo vínculos sociais e culturais, a posta-restante representava uma possibilidade de contato com um passado recém-perdido, e, portanto, com a própria origem. Além disso, Döblin lembra que a capital de Portugal era a última esperança para todos que se encontravam em situação semelhante: "e nós, refugiados pertencentes a esta Europa, aqui estávamos em Lisboa esperando pela boia de salvação que nos seria lançada do outro lado do oceano" (FANTASIA LUSITANA, 2010, 47:22 $47: 33)$.

Döblin está sempre a ressaltar o impacto negativo da guerra na vida das pessoas: o desespero, a tristeza, a desinformação, a incerteza, a separação dos entes queridos, ou seja, ele conta não apenas a sua própria história, mas também a dos seus pares judeus que se encontravam em situação semelhante. A exposição a este tipo de experiência traumática fazia com que se comportassem de modo obtuso; o futuro incerto e o tempo de espera fazia com que ficassem "num estado de sonolência inquieto, interrompido por frequentes momentos de irritação e ataques de impaciência" (FANTASIA LUSITANA, 2010, 48:39 - 48:45), malgrado gozarem uma certa condição de segurança em Portugal.

Por fim, aos 49min47s, o documentário de Canijo traz a última participação do escritor. Trata-se da chegada do Nea Hellas, o barco que os levaria para os Estados Unidos e daria um fim àquele longo período de espera. Os passageiros estavam ansiosos para embarcar, conforme relata Döblin: "quando finalmente foi dado o sinal para o embarque, gerou-se uma tal confusão que um funcionário, num tom plácido, gritou cá para baixo: 'Não empurrem, cavalheiros, não empurrem. Aqui não andam nazis atrás de vós"” (FANTASIA LUSITANA, 2010, 50:05 - 50:18). O comentário do membro da tripulação remetia à condição dos judeus perseguidos pelos nazistas, mas também ao encerramento do capítulo daquela história de guerra para esses passageiros, uma vez que navegariam rumo aos Estados Unidos, não correndo mais riscos. A última imagem que o romancista tem da Europa são as luzes da Exposição do Mundo Português.

\subsection{Erika Mann}

Erika Mann é a segunda estrangeira a ter voz em Fantasia Lusitana. Era filha primogênita do ganhador do Prêmio Nobel de Literatura (1929) Thomas Mann, célebre por romances como Os Buddenbrooks (1901), Morte em Veneza (1912) e A montanha 
mágica (1924). Nascida em Munique, Erika foi escritora, atriz, correspondente de guerra e fundadora do cabaré antifascista Die Pfeffermühle. Era homossexual e sua mãe, Katia Pringsheim, era de origem judia, portanto, Erika tinha vários motivos para ser perseguida pelos nazistas.

É a atriz Hanna Schygulla quem dá voz à Mann em Fantasia Lusitana, aos 22min46s. A primeira intervenção da intelectual escolhida por Canijo é referente à presença dos refugiados estrangeiros em Lisboa. Diferentemente de Döblin, Erika faz uma descrição mais aprofundada da aparência desses fugitivos, não poupando sequer os detalhes das indumentárias. Ela começa por lembrar que "Lisboa, o único porto livre e neutral da Europa, tornou-se no ponto de encontro e na sala de espera de todos os que fogem de Hitler" (FANTASIA LUSITANA, 2010, 22:46 - 22:56).

A partir de então, a escritora vai detalhar quem são esses fugitivos: "São desterrados, proscritos, os que aqui se reúnem. O número varia, mas são sempre aos milhares. Os refugiados chegam sem bagagem, sem dinheiro, frequentemente sem documentos de identificação" (FANTASIA LUSITANA, 2010, 23:05 - 23:19). Além da quantidade de degredados presentes em Lisboa, a jornalista relata a condição de pobreza que a guerra acaba por gerar nesses expropriados.

Semelhante ao romancista alemão, sua conterrânea também irá lembrar que a fuga por Lisboa acaba por ser a última esperança remanescente para aqueles perseguidos, que têm que aguardar pelo “[...] barco de salvação que os levará, para qualquer parte, daqui para fora, para longe do inimigo que os perseguia. Caçados por toda Europa esperavam agora o barco da salvação" (FANTASIA LUSITANA, 2010, 23:35 - 23:55). A escritora não apenas retoma o tema do calor insuportável de Lisboa, mas também relata os sentimentos causados por essa espera: "Apenas se esperava, melancolicamente, sob uma angústia desamparada e um calor sufocante; as nuvens pairavam baixas sobre a cidade, e os refugiados andavam sem sentido pelas ruas; nada podiam fazer e pouca esperança podiam ter" (FANTASIA LUSITANA, 2010, 24:05 - 24:32).

Mann irá então abordar a exploração que esses expatriados sofriam por parte dos portugueses em relação à hospedagem e alimentação, conforme a conhecida Lei da Oferta e da Procura. A filha de Thomas Mann diz que "os preços cobrados nos hotéis e restaurantes por serviços irrisórios são exorbitantes" (FANTASIA LUSITANA, 2010, 37:58 - 38:05). Em seguida, retomará a questão do estado de espírito daqueles refugiados, 
lembrando a atmosfera de angústia e de nervosismo presente nas ruas de Lisboa, onde se ouvia, agora, diversos idiomas europeus.

Assim como Alfred Döblin, a fundadora do cabaré antifascista, oriunda de um país norte-europeu, se surpreende com detalhes do sul da Europa que ela encontra em Portugal. Porém, sua visão não chega a ser preconceituosa como a do médico. Ela se refere apenas ao modo como os portugueses "aqui bebiam o café amargo e muitíssimo torrado - como só se pode encontrar no Sul de França, em Espanha e em Portugal" (FANTASIA LUSITANA, 2010, 40:17 - 40:24). Entretanto, o seu foco é nos refugiados, que chegavam à Lisboa, muitas vezes, já sem recursos. Ela explica que, mesmo sem condições financeiras de consumir nos pequenos cafés, esses estrangeiros ainda assim o faziam a fim de encontrar os seus pares:

Pessoas que falavam a mesma língua juntavam-se numa mesma mesa, os franceses com os belgas, os alemães com os austríacos e checos. Os noruegueses e os holandeses, que na sua grande maioria sabiam francês e alemão para além da sua língua materna, falavam uns com os outros numa língua que não era a sua (FANTASIA LUSITANA, 2010, 40:53 - 41:13).

Não obstante a classe social a que esses expatriados pertenciam em seus países de origem, ou os seus níveis culturais, todos estavam em Lisboa aguardando para deixar a Europa por um mesmo motivo: fugir da perseguição nazista. Dessa forma, as dificuldades encontradas para conseguir informações, emitir passaportes, obter vistos, deslocar-se até Portugal acabaram por desestruturar muitas dessas famílias e muitos acabavam por chegar ao seu último destino europeu apenas com a roupa que vestiam. Diferentemente de Döblin, que descreveu apenas o estado de ânimo desses refugiados, isto é, as incertezas, as angústias, os traumas e medos, Mann consegue ir além, pois, não apenas considera este aspecto da vida dessas pessoas, mas também, como uma boa correspondente de guerra, detalha as condições físicas dessas vítimas do nazismo. Ainda sobre o café, ela diz:

\footnotetext{
$\mathrm{O}$ ar era fumarento e consumido da respiração de tanta gente. A maioria dos refugiados trazia a mesma roupa com que tinha deixado o seu país ou o país que the concedera asilo; vestiam roupas gastas e porcas, e muitas vezes rasgadas. Pairava no ar um cheiro de sujidade. Mal se conseguia respirar o ar deste pequeno café terrivelmente "internacional" de Lisboa (FANTASIA LUSITANA, 2010, 41:15 - 41:52).
}

A condição desses desterrados era precária; estavam desprovidos de tudo: seus lares, suas ocupações, seus bens. No entanto, Erika Mann consegue mostrar que, embora tivessem conseguido chegar até a segurança do solo neutro português, ainda assim eles se sentiam infelizes. Este mesmo sentimento de infelicidade também havia sido compartilhado por Döblin, como já foi visto. Ela também ressalta a iluminação noturna 
de Lisboa, uma cidade que podia se dar ao luxo de acender suas luzes uma vez que não era alvo de bombardeios: "Eu estranhava quando anoitecia e não escureciam a cidade. Parecia-me pouco natural que ao cair da noite houvesse luzes nas janelas e que acendessem os candeeiros da rua. Era surpreendente para mim que não temessem os bombardeamentos nazis" (FANTASIA LUSITANA, 2010, 43:22 - 43:48).

Contudo, essa claridade presente em Lisboa não era vista como algo positivo. Acostumados à escuridão das cidades sob ataque aéreo, esses perseguidos conheciam o seu inimigo, ou seja, sabiam de quem tinham que se proteger. Uma vez em território neutro, não corriam os mesmos riscos que em seus países de proveniência, mas o inimigo ainda continuava a atacar e a fazer suas vítimas. Ele precisava ser combatido, ser neutralizado. É este pensamento que vemos no testemunho de Mann a respeito da segurança de Portugal:

Pior do que a catástrofe em si é a ameaça de catástrofe à qual se está inexoravelmente exposto. Conhecer o inimigo, receá-lo, desprezá-lo e saber que ele está muito perto sem o poder combater é muito pior do que o combate em si. Quem se defende e é bem sucedido, não se sente infeliz. Quem vai à luta por uma boa causa, não se sente infeliz, quem sabe que vai vencer, não se sente infeliz. Em Londres tinha-me sentido feliz. Mas aqui não (FANTASIA LUSITANA, 2010, 44:26-45:15).

$\mathrm{Ou}$ seja, esse sentimento contrastante de felicidade versus infelicidade experimentado por Erika também é sentido por Alfred Döblin em seu testemunho, conforme já vimos. Ela resume a sensação de estar desterrada quando, pelo fato de ter sido convocada a comparecer ao serviço de estrangeiros português, se depara com uma fila muito extensa de estrangeiros que tomava de quatro a cinco blocos. É quando a dramaturga reflete que

[...] toda esta gente - belgas, dinamarqueses, noruegueses, homens, mulheres e crianças - foram surpreendidos nos seus países de origem pelo inimigo como se é atingido por um terramoto ou um dilúvio. De repente, tudo estava destruído e perdido. De repente, viam-se sem casa, perseguidos e rejeitados e, de repente, estavam aqui, à espera. É estranhíssimo. Esta sensação de infinito desamparo provoca em mim um grande medo (FANTASIA LUSITANA, 2010, 46:03 - 46:47).

A imprevisibilidade que marca a vida das vítimas da guerra gera ansiedade e medo, pois reforça a fragilidade do homem diante de forças as quais não tem domínio, e que estão, no caso, associadas à violência gerada pelo estado de exceção. Os argumentos de Mann evidenciam, ainda, não só a vulnerabilidade humana diante do inesperado, como também a urgência da fuga para garantia da sobrevivência. 
Assim termina o testemunho de Erika Mann. Em linhas gerais, tanto o relato de Döblin quando o dela trazem aspectos bastante semelhantes, principalmente em relação ao sentimento de tristeza, medo ou desestruturação que acometia aquelas pessoas. $\mathrm{O}$ discurso do médico reforça os choques culturais que o impactaram em Portugal, como o clima, os festejos, os sons da cidade, bem como o mal hábito de se cuspir pelas ruas. A escritora concentra a sua atenção nos refugiados em si, em seus aspectos físicos, emocionais, em suas origens e destinos. Passamos a analisar agora o testemunho do terceiro e último estrangeiro presente em Fantasia Lusitana.

\subsection{Antoine de Saint-Exupéry}

Talvez o mais conhecido entre os três estrangeiros que contrapõem a propaganda salazarista, Antoine de Saint-Exupéry, autor de O pequeno príncipe (1943), aviador, piloto e correspondente de guerra, escritor e ilustrador, deixou relatos acerca de Lisboa por ocasião de sua passagem por esta capital em dezembro de 1940. Suas reminiscências são interpretadas pela voz do ator Christian Patey a partir dos $28 \min 46$ s. Alinhado com os relatos de Döblin e de Mann, o aviador francês também destaca a felicidade aparente vivida em Lisboa, com suas luzes e o seu burburinho, apesar de sua fragilidade perante o poderio bélico circundante.

Em seus escritos, o intelectual personifica a capital portuguesa, transformando-a na figura de uma mãe que desconhece o paradeiro do filho que foi arregimentado pela guerra, mas se mantém sorrindo, segura e confiante. Assim, Lisboa se transforma numa personagem que ganha voz:

$$
\begin{aligned}
& \text { Lisboa, que tinha montado a mais bela exposição do mundo, sorria de um } \\
& \text { sorriso pouco pálido, como o das mães que não têm notícias de um filho que } \\
& \text { está na guerra e tentam salvá-lo com a auto-confiança: "O meu filho está vivo, } \\
& \text { porque eu estou a sorrir..." (FANTASIA LUSITANA, 2010, 28:58 - 29:11). }
\end{aligned}
$$

No pequeno trecho acima, Saint-Exupéry traça dois cenários concomitantes: o das comemorações do Duplo Centenário através da Exposição do Mundo Português, chamada de "a mais bela exposição do mundo", e o relativo ao posicionamento de Lisboa perante uma situação grave e séria (a tragédia da guerra), personificada na mãe supracitada.

Por ser piloto durante a guerra, conhecia a violência bélica de perto, portanto, reconhecia a vulnerabilidade portuguesa e sabia que o país onde ele se encontrava poderia ser um alvo fácil para Hitler, se assim o líder alemão o quisesse. Por outro lado, grande 
parte da população portuguesa, influenciada pela máquina da propaganda nacional, não compartilhava da opinião de Saint-Exupéry, acreditando na diplomacia de Salazar e no status de neutralidade.

Dessa forma, o olhar do estrangeiro é capaz de penetrar mais profundamente aquele contexto e perceber a real possibilidade de ataque que pairava no ar. Em outras palavras, o autor de $O$ pequeno príncipe consegue fazer uma análise mais sensata acerca do risco que Lisboa corria, ao passo que Portugal celebrava o Duplo Centenário de forma portentosa e exuberante. Esta postura de "autoconfiança" atribuída à cidade por SaintExupéry e o sorriso representando a felicidade alcançada com as festividades daquele ano (não obstante a desgraça no resto da Europa) podem também ser interpretadas como alienação por parte da nação lusitana.

A frase "O meu filho está vivo, porque eu estou a sorrir..." teria como paráfrase: “o meu sorriso se dá pelo fato de eu julgar que o meu filho esteja vivo, embora eu não tenha notícias dele", ou seja, "eu desejo tanto ter boas notícias do meu filho (e temo tanto a sua morte) que sorrio, para provar que tudo está bem, como eu desejo", o que, de fato, não é garantia de vida - não por acaso este sorriso é "pálido".

Ainda utilizando a personificação para dar voz à capital portuguesa, o escritor francês destaca o posicionamento de Portugal perante o conflito:

\footnotetext{
"Vejam", dizia Lisboa, "como sou feliz, tranquila e bem iluminada...". O continente inteiro punha em Portugal como numa montanha selvagem, o peso das suas tribos de caça; Lisboa desafiava a Europa: "Como podem tomar-me por alvo quando tenho tanto cuidado para não me esconder! Quando sou tão vulnerável..." (FANTASIA LUSITANA, 2010, 29:40 - 30:00).
}

Ao tornar-se uma personagem nos relatos do escritor francês, o solilóquio da capital portuguesa é utilizado como recurso para justificar o clima de festividades nesta cidade ao mesmo tempo em que o resto da Europa convulsiona. É como se Lisboa desdenhasse do destino das outras nações e duvidasse que pudesse ser atacada. Assim, o trecho "'Vejam', dizia Lisboa, 'como sou feliz, tranquila e bem iluminada..." pode representar uma posição de exibicionismo por parte desta cidade, com o uso do imperativo "vejam", convidando todos a prestar atenção à sua felicidade, tranquilidade e iluminação, uma vez que os países beligerantes estavam desprovidos desses elementos.

Para o escritor francês, toda a pompa oriunda das efemérides do Duplo Centenário, ao mesmo tempo em que populações perseguidas sucumbem com a guerra, poderia ser tomada como uma provocação portuguesa (talvez inconsciente): "Lisboa desafiava a 
Europa”. É como se aquela capital não concebesse um possível ataque diante de sua fragilidade. No monólogo, o excerto "como podem tomar-me por alvo quando tenho tanto cuidado para não me esconder! Quando sou tão vulnerável...” oferece um paradoxo: "não ter cuidado para se esconder" versus "ser tão vulnerável”. Ora, a lógica diz que quem é vulnerável deve se esforçar por se proteger ou, pelo menos, não se fazer notar. Portugal faz justamente o contrário, denotando um comportamento ilógico, o que pode ser compreendido como excesso de confiança ou como uma grande ignorância por parte de seus governantes, quando sabemos que toda essa celebração estava alinhada com a ideologia do Estado Novo.

No próximo trecho de Fantasia Lusitana em que as memórias do aviador são evocadas, temos uma descrição mais pormenorizada acerca da postura portuguesa em relação à celebração do passado glorioso de Portugal, visão esta conciliada com o mito imperial definido por Fernando Rosas.

Portugal ignorava o apetite do monstro. Recusava-se a acreditar nos sinais. Exibia todas as suas maravilhas. Mostrava os seus grandes homens. À falta de um exército, à falta de canhões, levantara contra o ferro do invasor todas as suas sentinelas de pedra: os poetas, os navegadores, os conquistadores. Todo o passado de Portugal, à falta de exército e de canhões, bloqueava o caminho. Quem ousaria esmagá-lo diante da herança de um passado tão grandioso? (FANTASIA LUSITANA, 2010, 32:14 - 32:41).

Saint-Exupéry utiliza a palavra "monstro" para se referir à guerra em si, ou, quem sabe, ao próprio Adolf Hitler. Entretanto, este "monstro" possui um apetite ignorado por Portugal, e é justamente esta ignorância portuguesa que chama a atenção do aviador. Ele não consegue compreender como aquele pequeno país ibérico, indefeso, se comparado ao poderio militar dos países beligerantes, se permitia estar em festa, em se expor grandiosamente quando o "monstro" rondava.

Mais que isso, o correspondente de guerra parece perceber que esta ignorância portuguesa não se resumia a apenas uma falta de conhecimento ou a uma desinformação - pelo contrário, era uma recusa. Portugal "recusava-se a acreditar nos sinais", o que remete ao ditado popular "o pior cego é aquele que não quer ver".

Diferentemente do que era veiculado em Portugal pelos materiais propagandísticos quanto a seu excelente preparo marcial, difundido através dos desfiles militares, dos exercícios de defesa da nação, ou da ótima diplomacia internacional, SaintExupéry tem ciência do real cenário português referente "à falta de um exército, à falta 
de canhões", isto é, em relação à deficitária condição portuguesa nesse quesito, se comparada à condição alemã, italiana, britânica ou estadunidense.

O escritor francês fica perplexo diante da atitude portuguesa, e, assim como Döblin, também vai propor uma explicação irônica para tal fenômeno. Segundo ele, já que Portugal não tinha condições militares de se defender de um possível ataque, já que o seu exército era vulnerável, "levantara contra o ferro do invasor todas as suas sentinelas de pedra: os poetas, os navegadores, os conquistadores. Todo o passado de Portugal [...] bloqueava o caminho".

Em outras palavras, não tendo os meios de se proteger efetivamente, Portugal não tem outra escolha a não ser exibir a única coisa que lhe resta, ou seja, "as suas sentinelas de pedra": as personalidades históricas dos séculos XV e XVI, em suma, os heróis do passado, que viveram num período considerado glorioso, e que, na contemporaneidade, se converteram em heróis míticos. É como se, não tendo o que oferecer no presente, Portugal recorresse ao seu passado para poder endossá-lo. Assim, o autor francês lança a irônica pergunta: "quem ousaria esmagá-lo diante da herança de um passado tão grandioso?" quando sabemos que, num contexto de guerra, o que determina a possibilidade de uma invasão ou de um ataque é a condição militar presente (e não passada) de um país.

A seguir, Saint-Exupéry fará a mesma coisa que Döblin e Mann fizeram ao se encontrar em Lisboa: comparar o cenário de guerra de onde provinham ao cenário português. Porém, assim como ambos, o autor de $O$ pequeno príncipe irá lamentar a situação lisboeta de então:

As cidades na minha terra, à noite, eram cor de cinza. Eu tinha perdido o hábito de ver a luz e esta capital radiosa causava-me uma espécie de mal-estar. Eu sentia pesar sobre Lisboa a noite da Europa habitada por grupos errantes de bombardeiros, como se eles tivessem farejado de longe este tesouro. E por detrás do seu sorriso, Lisboa parecia-me mais triste do que as minhas cidades apagadas. Mas Portugal tentava acreditar na felicidade, com os seus serviços de mesa, os seus candeeiros e a sua música. Brincava-se à felicidade em Lisboa, para Deus poder acreditar (FANTASIA LUSITANA, 2010, 34:21 35:00).

$\mathrm{O}$ aviador reconhece que as cidades francesas eram cinzentas à noite, diferentemente de Lisboa, causando-lhe mal-estar pelos contrates encontrados em terras lusitanas. Um dos motivos desse incômodo seria porque ele reconhece que "este tesouro" poderia ser atacado a qualquer momento, porém, o que fica mais evidenciado é o fato de que, muito embora Portugal fosse um país neutro e sua capital pudesse gozar de um estado 
de felicidade patenteado pelas celebrações do Duplo Centenário, este contentamento lhe parecia artificial. É como se Portugal, embora triste, fabricasse uma ilusão de felicidade.

Ora, viver sob um regime ditatorial, conquanto travestido de uma aura de proteção, segurança e providência que o Estado Novo primava por sustentar, era sempre viver sob um clima de medo, de repressão e de censura. Essas apreensões eram intensificadas com a ameaça da guerra que se desenvolvia muito próxima. De acordo com as impressões de Saint-Exupéry, o país que abrigava os refugiados não era, de fato, feliz, mas "tentava acreditar na felicidade". E nessa tentativa criava-se uma realidade fictícia, cheia de luzes, música e "heróis" a ostentar.

É justamente esta ostentação que a testemunha francesa passará a focar então em suas memórias. Diante do cenário desagregador pelo qual a Europa passava, a elite portuguesa insistia em manter as aparências e não se envolvia nem com os refugiados europeus que chegavam em Portugal em grande quantidade, nem com seus patrícios que viviam em condições de pobreza:

\footnotetext{
Lisboa também devia o seu clima de tristeza à presença de certos refugiados. Não falo dos proscritos à procura de asilo. Não falo de imigrantes à procura duma terra para fecundar com o seu trabalho. Falo dos que se expatriavam para longe da miséria dos seus para salvarem o seu dinheiro. Todas as noites, o casino do Estoril enchia-se de fantasmas. Cadillacs silenciosos, que fingiam ir a algum sítio, deixavam-nos na areia fina da entrada. Eles vestiam-se de gala, como antigamente. Mostravam o peitilho ou as pérolas. Convidavam-se uns aos outros para jantares de figurantes, onde não teriam nada para dizer (FANTASIA LUSITANA, 2010, 35:16 - 35:59).
}

Saint-Exupéry está a descrever uma minoria de refugiados, provavelmente com recursos financeiros, que saíram de seus países de origem, tentando salvaguardar a vida e algum patrimônio, mas que viviam num estado fantasmático. Todo o comportamento desse pequeno grupo de indivíduos (vestir-se de gala e frequentar cassinos, por exemplo), representava uma forma de negar que estavam despojados da vida que levavam. $\mathrm{O}$ comportamento dessas pessoas se assemelha àquele de Portugal ao evocar os renomados nautas e desbravadores dos séculos pretéritos num contexto atual de fragilidade.

Essa burguesia decadente desperta comiseração por parte do intelectual francês. Ele admite que "[...] ia vê-los, às vezes. Não sentia nem indignação nem ironia, mas uma súbita angústia. A mesma que nos perturba no jardim zoológico diante dos sobreviventes duma espécie extinta” (FANTASIA LUSITANA, 2010, 36:12 - 36:23). Embora o escritor não julgue de forma negativa essa elite, ele deixa claro que, pelo fato de 
pertencerem à "uma espécie extinta", ele se sente angustiado, pois sabe se tratar de uma "casta" condenada.

O grau de ilusão dessas pessoas se equipara àquele da nação portuguesa no tocante a fugir da realidade presente ao querer reviver o passado. $\mathrm{O}$ aviador explica que elas

[...] esforçavam-se por sentir esperança, desespero, medo, inveja e júbilo, como se estivessem vivos. Jogavam fortunas que talvez, naquele exacto momento, tivessem deixado de ter significado. Esforçavam-se por acreditar, agarrandose ao passado, como se desde há alguns meses não tivessem começado a rebentar na terra, na legitimidade da febre que sentiam, na cobertura dos seus cheques, na eternidade das suas convenções (FANTASIA LUSITANA, 2010, $36: 30-37: 00)$.

O autor insiste na ideia de que esses já não tão ilustres cidadãos são "fantasmas", uma vez que procuram experimentar os sentimentos "como se estivessem vivos". Percebe-se um esforço por parte dessas pessoas em querer provar que ainda pertencem a uma realidade que já não existe mais, da mesma forma que o próprio país faz em relação ao seu célebre passado. Não por acaso, a fala de Saint-Exupéry termina comparando o clima fictício vivido tanto por essas pessoas quanto pela capital portuguesa: "Era irreal. Parecia um bailado de bonecas. Mas era triste. Da mesma maneira que Lisboa brincava à felicidade, eles fingiam que acreditavam que iam regressar em breve" (FANTASIA LUSITANA, 2010, 37:21 - 37:32).

Deste modo, as recordações e impressões de Döblin, Mann e Saint-Exupéry referentes ao período em que estiveram em Lisboa são muito semelhantes no que diz respeito à falsa alegria sentida naquela cidade. Não obstante estarem fugindo da sanha destrutiva da guerra e de se encontrarem em território seguro, os três estrangeiros, cada um a seu modo, preferem a escuridão das cidades que deixaram, à luminosidade de Lisboa. De certa forma, o trio percebe a alienação de Portugal em relação à guerra em curso. Referente a esses dois mundos coexistentes, a pesquisadora Susana Guerra reflete:

Alfred Döblin, Erika Mann, Antoine de Saint-Exupéry: vozes solitárias, improváveis mas privilegiadas, permitem ouvir (e, indiretamente, ver) outra história. Com eles, sentimos o peso de presenciar uma farsa em cada manifestação cotidiana, em cada celebração, em cada ato de governo (GUERRA, 2015, p. 97).

Susana Guerra chama os testemunhos dos três estrangeiros ilustres de "outra história", pois contrasta com a história contada pela propaganda de Salazar. Dessa forma, ao entrarmos em contato com o ponto de vista desses estrangeiros, toda a ideologia do Estado Novo, desnudada diante de fatos incontestáveis, acaba se tornando uma "farsa", nas palavras da acadêmica, como estamos procurando demonstrar nesta dissertação. 
Como sabemos, a falta de empatia para com as vítimas da guerra e o olhar voltado para si mesmo por parte do Portugal salazarista, materializado em forma de festas e celebrações nacionalistas e religiosas, têm a sua origem nos ideais do Estado Novo através dos instrumentos da propaganda nacional. Dessa forma, uma vez que já exploramos elementos dos dois níveis antagônicos que compõem Fantasia Lusitana, passaremos a analisar a intercalação que se dá entre esses elementos e seus sentidos. 


\section{CAPÍTULO 3: A ALTERNÂNCIA DAS CAMADAS}

Como já abordamos, a primeira manifestação pertencente, de fato, ao nível de realidade da guerra em Fantasia Lusitana se dá quando aproximadamente um terço do filme é transcorrido. Estamos falando do já analisado excerto de Alfred Döblin aos 19min03s. Até então, a propaganda salazarista teve voz de modo abrangente, inclusive nas cenas de ataques aéreos do documentário sobre as Blitz voltada à população portuguesa, o que nos fez classificá-lo como material propagandístico, apesar das fortes imagens dos bombardeios e suas consequências.

A partir do surgimento do primeiro relato desse estrangeiro, a montagem de Fantasia Lusitana passa a intercalar cenas que sustentam o ponto de vista das três testemunhas, nas quais o espectador ouve as reminiscências nos idiomas alemão e francês, dependendo de quem tece a narrativa, com cenas difundidas pela propaganda salazarista, geralmente com a narração pomposa em língua portuguesa característica à época, cuja temática se distancia muito do assunto abordado pelos forasteiros.

Este jogo de vozes, cenas e pontos de vista faz com que o espectador oscile entre os dois níveis contraditórios de realidade, o que gera um efeito perturbador propositalmente planejado por Canijo, funcionando como uma forma de crítica ao regime português de então, voltado a si mesmo e alheio à gravidade da situação bélica europeia. Em suma, cada vez que a fala de um dos estrangeiros é interrompida para que cenas da propaganda estatal ganhem voz, cria-se um profundo mal-estar, justamente por conta da futilidade que a maioria dessas intervenções oferece.

\subsection{A "Nau Portugal"}

A cena que surge logo após as primeiras impressões de Alfred Döblin são as da “Nau Portugal”. Idealizada por Leitão de Barros, a referida embarcação foi construída para ser uma das atrações da Exposição do Mundo Português (1940), evento promovido pela ocasião do Duplo Centenário. Era uma réplica das naus do período da expansão marítima e se encontrava nas docas de Belém, próxima ao Padrão dos Descobrimentos, podendo o seu interior ser visitado. Segue abaixo a transcrição do trecho recuperado por Fantasia Lusitana: 


\begin{abstract}
A Nau Portugal, um dos maiores atrativos da Exposição do Mundo Português, tem uma história empolgante que os operadores da SPAC fixaram em imagens, como fizeram, aliás, para tudo que assinalou no nosso país neste ano áureo de 1940. Iniciativa ousada de Leitão de Barros, foi construída sob a direção do mestre Mónica nos estaleiros da Gafanha, em Aveiro. No dia do bota-abaixo, juntaram-se milhares de pessoas vindas de toda a parte. Como em todos os lançamentos de navios, a alegria somava-se à ansiedade. E deu-se um acidente (FANTASIA LUSITANA, 2010, 21:51 - 22:45).
\end{abstract}

Logo após a sua inauguração, a "Nau Portugal' tomba na presença de todos os que ali se encontravam para as festividades. Nos dias que se seguiram, a embarcação é então colocada na posição correta, é restaurada, reinaugurada, e se mantém fixa até o final da exposição, cumprindo o seu papel comemorativo propagandístico. No entanto, Canijo, seletivamente, interrompe as imagens logo após a queda da nau, sem, contudo, revelar o que teria ocorrido com ela. $\mathrm{O}$ fato de o cineasta propor um corte de cena exatamente neste ponto é muito significativo e fortalece a tese de desconstrução da propaganda salazarista. Para Canijo, mostrar ao espectador o desfecho do ocorrido com aquela atração não contribuiria com a proposta da película, pois reforçaria o ponto de vista do Estado Novo.

Com menos de um minuto de duração, o episódio da embarcação em Fantasia Lusitana inicia com um intertexto de fundo preto com os dizeres "A NAU PORTUGAL" (FANTASIA LUSITANA, 2010, 21:51) em letras maiúsculas na cor branca. Em seguida, vemos pessoas entrado a bordo da nau através de uma escada adjacente enquanto centenas de pessoas observam em terra. Há um corte e então o foco recai sobre um canhão antigo que se encontra no convés, e, ao fundo, nota-se a multidão reunida no cais aguardando pelo lançamento (Figura 12). Em seguida, em plano aberto, a câmera em movimento passa a capturar a imagem dos visitantes.

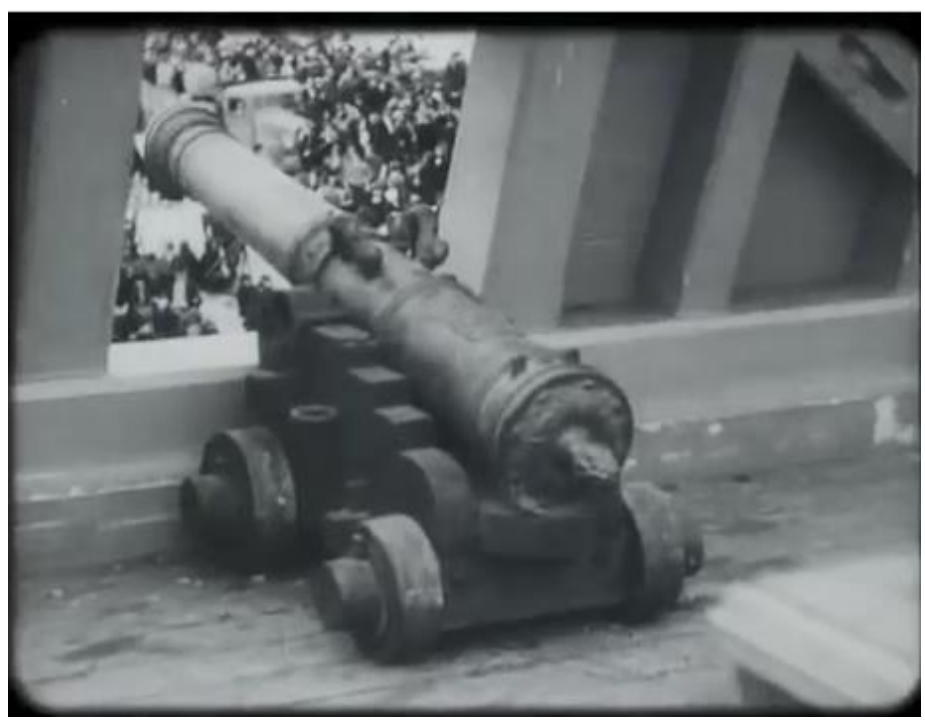

Figura 12: Canhão antigo a bordo da "Nau Portugal". 
Por fim, quando o locutor começa a falar sobre o lançamento da embarcação, a câmera capta a imagem de homens com machados à mão, derrubando as estacas que prendiam a nau, bem como outros que finalmente cortam a última corda que a segurava para lançá-la por água. Os tripulantes, muitos com seus chapéus em mão, acenam alegremente e em instantes a nau começa a virar. Nesse momento alguns tripulantes se agarram firmemente onde podem e outros saltam à água (Figura 13). Logo após o locutor anunciar que "deu-se um acidente", a narração termina, uma música de fundo, com um tom dramático, assume a parte sonora e continua por poucos segundos até o momento em que a "Nau Portugal" tomba por completo.

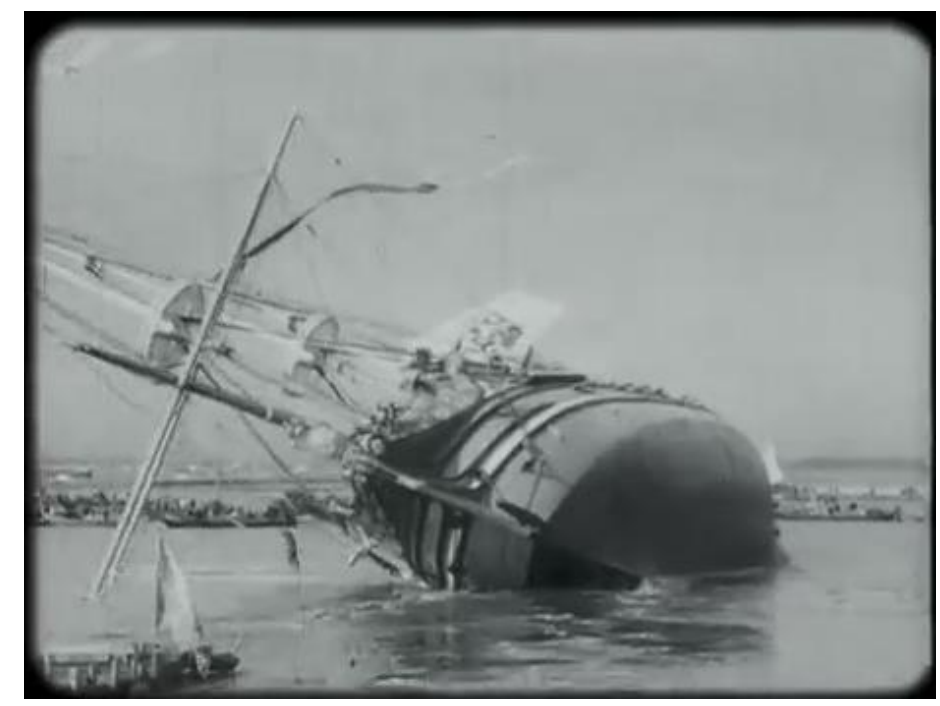

Figura 13: Cena da "Nau Portugal" em tombamento.

O fato de a nau ter sido batizada com o nome Portugal é muito significativo, pois ela, metaforicamente, representa o país. Ao mostrá-la caída, sem nenhum tipo de controle, com a tripulação em desespero tentando salvar-se, Canijo revela, ao espectador de Fantasia Lusitana, toda a fragilidade daquela nação governada por Salazar. Muito embora a referida embarcação tivesse sido resgatada e cumprido o seu papel como atração comemorativa (informação revelada pelo cinejornal à época, cuja população de 1940 ficou sabendo), ao interromper a cena com a derrocada da nau, o realizador questiona o mito imperial criado pelo Estado Novo. Dessa forma, o cineasta demonstra que os portugueses perderam a habilidade marítima que os consagrou séculos atrás, invalidando, portanto, a conexão com os pioneiros da navegação e das descobertas, mito tão ao gosto do regime. Vale lembrar que uma das premissas daquela grande exposição era justamente celebrar a portugalidade através dos heróis do passado, conforme veremos nas cenas sobre o Cortejo Histórico. 
A respeito na montagem em Fantasia Lusitana referente a este acidente náutico, Ana Salgueiro Rodrigues pondera que:

[...] o desastre da 'Nau Portugal' aquando da Exposição do mundo português [...], imagem que Canijo transporta subversivamente do Jornal português de actualidades, para lhe conferir um valor bem diferente do que lhe foi atribuído por Lopes Ribeiro, pode ser lido como uma imagem simbólica: símbolo da ruína da imagem megalómana e fantasiosa de Portugal criada pelo Estado Novo; símbolo da ruína do mundo moderno, nascido justamente do movimento expansionista peninsular para o Atlântico; mas símbolo também da ruína da arte contemporânea, incapaz de conduzir o homem para um qualquer porto de abrigo, mas que, apesar disso, continua à deriva, irónica e sempre questionando, por considerar [...] que até questões sem resposta devem continuar a ser colocadas (RODRIGUES, 2010, p. 76).

Após o episódio da "Nau Portugal”, temos a primeira intervenção de Erika Mann, quando a intelectual alemã discorre sobre a presença maciça de refugiados europeus nas ruas de Lisboa e o estado de espírito em que se encontravam (melancólicos, angustiados, desnorteados e impotentes). As imagens que são exibidas revelam cenas das ruas lotadas da capital portuguesa e parecem não ter sido captadas de forma oficial, pois foram feitas amadoramente a partir do interior de um veículo em movimento. Em seguida, uma sequência de fotografias de refugiados é exibida, mostrando-os cansados, com os semblantes incertos, muitos deles juntos de suas bagagens, expediente utilizado pela montagem para dar significado à narrativa de Mann e para contrastar com as cenas comemorativas do Duplo Centenário.

\section{2 $O$ cinema a serviço do regime salazarista}

Antes de nos enveredarmos na análise dos trechos de Fantasia Lusitana, veremos brevemente de que forma o mundo cinematográfico foi utilizado pelo Estado Novo. Segundo Luís Reis Torgal, o cinema foi

considerado um instrumento importante da propaganda do regime. Salazar, pelo seu ruralismo e pela sua formação católica de tipo conservador [...] poderia não ter uma particular sensibilidade para a estética da «Sétima Arte», mas racionalmente entendeu que não poderia abdicar desse meio para impor a sua doutrina, em termos de propaganda. Parafraseando as suas próprias palavras, o cinema seria importante para «informar», primeiro, e para «formar» depois (TORGAL, 2011, p. 67).

Conhecedor do poder que o cinema poderia exercer na formação da população portuguesa, Salazar o utilizou de forma ampla. Entretanto, para que lograsse êxito, houve a necessidade da criação de órgãos governamentais que o promovessem e de pessoas que estivessem à frente dessas organizações. É o caso da formação do Secretariado da 
Propaganda Nacional (SPN) em 1933, dirigido por António Ferro, conforme explica Torgal:

\begin{abstract}
A escolha do jornalista, escritor, cinéfilo e intelectual multifacetado António Ferro para a direcção do Secretariado da Propaganda Nacional e, depois, para o Secretariado Nacional da Informação, mostra afinal que Salazar, apesar do seu tão decantado ruralismo, soube entender as virtudes «públicas», ou «políticas», dos meios de comunicação, antigos e modernos, como a literatura, o panfleto, o cinema ou a rádio, que pôs a funcionar, de forma regular, em 1935 (TORGAL, 2011, p. 35).
\end{abstract}

Ferro era um admirador dos governos fascistas, principalmente do italiano. Em 1927, ele

[...] publica Viagem à Volta das Ditaduras. O seu ideário (já) está em consonância com o fascismo, como se depreende do modo como se apresenta a Mussolini: «Eu sou um admirador sincero do fascismo e do seu chefe. Desejo esclarecer o meu país sobre a actual política italiana» (PITA, 2011, p. 46).

Vemos na declaração do chefe do SPN o apreço que ele tem pelas ditaduras, principalmente a da Itália. Stefano Salmi e Davide Poli o definem como "brilhante intelectual lisboeta com simpatias claramente fascistas e modernistas" (SALMI; POLI, 2010, p. 382). Os pesquisadores italianos também informam que Ferro esteve várias vezes na Itália, e, “admirador do Futurismo e de Gabriele D’Annunzio, fez uma memorável entrevista com Benito Mussolini em Roma, utilizando a filmadora como um recurso modernista, no estúdio do Duce no Palazzo Venezia” (SALMI; POLI, 2011, p. 382).

Uma vez conhecido o alinhamento ideológico do responsável pelo SPN, torna-se fácil compreender o tipo de propaganda que seria então difundida em Portugal. Por conseguinte, essa ideologia se reflete no cinema e na cultura de forma geral. Contudo, há um desejo por parte do regime em se destacar de outros governos congêneres e de se definir como único. É o que explica Torgal: “O Estado Novo sempre se apresentou a si próprio como uma forma 'original' de regime autoritário, procurando distanciar-se, desde o início de sua formação e devido a sua alegada matriz católica, do "totalitarismo"” (TORGAL, 2011, p. 64).

O intento do governo em se manter incomparável reflete na difusão da propaganda. Isso pode ser constatado na ocasião em que Salazar inaugura o SPN, em 26 de outubro de 1933:

[...] Salazar fala da propaganda, procurando - como diz - «abstrair de serviços idênticos noutros países, dos exaltados nacionalismos que os dominam, dos teatrais efeitos a tirar no tablado internacional» e tratar - conforme também acrescenta - «do nosso caso comezinho». E o «nosso comezinho» é «o caso nacional», que está acima dos interesses particulares, o caso de uma nação que 
deve informar sobre aquilo que se vai fazendo, porque - diz numa frase de sabor maurrasiano - «politicamente só existe o que o público sabe que existe» (TORGAL, 2011, p. 65-66).

Dessa forma, preza-se pelo "comezinho", isto é, o simples, o caseiro, o nacional; em outras palavras, aquilo que Salazar deseja que seja definido como a identidade de Portugal. Portanto, os "anos 1930 voltam a marcar de maneira clara e significativa o momento mais filofascita do regime salazarista. Em 1935, o cinema depende diretamente do Secretariado da Propaganda Nacional” (SALMI; POLI, 2010, p. 382).

Consequentemente, alguns diretores cinematográficos tiveram destaque na produção de filmes que promoveram a ideologia do regime. Acerca do cinema, "o Estado Novo utilizou-o habilmente e de forma 'moderna' na propaganda, através de cineastas como Lopes Ribeiro ou mesmo Leitão de Barros" (TORGAL, 2011, p. 35). Relativamente ao primeiro, Torgal o define como o "mais significativo e confesso realizador do salazarismo, o grande cineasta António Lopes Ribeiro, falecido em 14 de Abril de 1995" (TORGAL, 2011, p. 72).

É justamente a referência a um filme de Lopes Ribeiro que aparecerá num corte abrupto em Fantasia Lusitana, após o espectador ter acompanhado as cenas das mazelas vividas pelos refugiados estrangeiros em Lisboa, levando-o novamente ao território da fantasia.

A edição proposta pela montagem do documentário introduz, repentinamente, um intertexto com os dizeres: "Uma Estreia de Gala" (FANTASIA LUSITANA, 2010, 24:34). Trata-se do lançamento do filme Feitiço do Império (1940), de António Lopes Ribeiro (Figura 14), realizador que havia lançado alguns anos antes a película $A$ Revolução de Maio (1937), presente diegeticamente no romance $O$ ano da morte de Ricardo Reis, de José Saramago, e mencionada na introdução desta dissertação. Apesar de ambos os filmes possuírem uma alta carga ideológica em prol do Estado Novo e de serem claramente materiais propagandísticos, eles não representam uma tendência daquela época. A esse respeito, Torgal explica que

Em cerca de sessenta filmes produzidos nos anos trinta e quarenta, as décadas de maior expressão ideológica do Estado Novo, apenas dois se podem assim classificar, ou seja, 3,5\%. São esses A Revolução de Maio, de 1937, realizado em pleno período de afirmação do Estado Novo e de militância anticomunista perante o «perigo espanhol», e Feitiço do Império, de 1940, o «ano áureo» das comemorações do Duplo Centenário da Fundação da Nacionalidade e da Restauração e da Exposição do Mundo Português, tempo de glória para o regime de Salazar e de propaganda para Portugal e do seu Império (TORGAL, 2011, p. 72). 
De qualquer modo, o fato de Canijo incluir essas cenas de arquivo referentes à estreia de Feitiço do Império em Fantasia Lusitana demonstra que o filme de Lopes Ribeiro simboliza fielmente a ideologia salazarista, e que poderia, portanto, representar a camada da propaganda. De maneira autoexplicativa, o "império" presente no título da película se refere ao próprio império português, mais especificamente às então colônias africanas que posteriormente iriam adquirir status de "províncias ultramarinas". Já a palavra "feitiço", refere-se ao fascínio exercido por tal império àqueles que viriam a conhecê-lo, ou seja, é o caso do personagem protagonista Luís, vivido pelo ator Luís de Campos, jovem de origem portuguesa criado nos Estado Unidos e que preocupava os seus pais por estar se "americanizando". Assim, os genitores de Luís convencem-no a visitar um tio que morava em Angola a fim de fazer uma caçada e de conhecer o famoso "império" português.

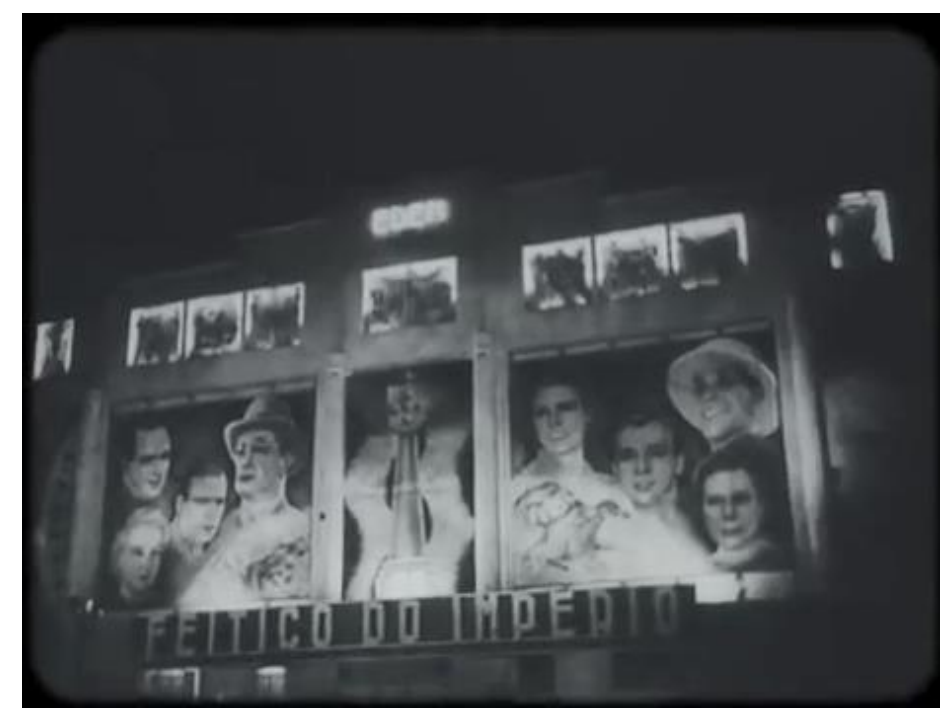

Figura 14: Divulgação do filme Feitiço do Império (1940) de António Lopes Ribeiro.

Da mesma forma que em A Revolução de Maio, esta película também aborda o caso de uma ““conversão' - a 'conversão' de um luso-americano às virtudes de Portugal e do seu Império" (TORGAL, 2011, p. 82). Após passar por Portugal, Guiné, Angola e Moçambique, e de conhecer de perto "as belezas do império", o jovem Luís fíca "enfeitiçado" por tudo que vê, rompe seu relacionamento com "a frívola e intolerante americana Fay" (TORGAL, 2011, p. 84), e elege como namorada Mariazinha, filha de um colono português em Angola, "jovem e bonita, dedicada a ensinar os pretinhos a ler português, através da Cartilha Maternal, e o catecismo católico" (TORGAL, 2011, p. 84). Mais uma vez a fórmula de conversão à ideologia salazarista por meio da 
simplicidade e da ingenuidade de uma mulher é utilizada, conforme já havia sido em $A$ Revolução de Maio.

As cenas de arquivo referentes à estreia de Feitiço do Império presentes no documentário de Canijo mostram vários homens e mulheres vestidos elegantemente, dirigindo-se à sala de projeção para assistirem ao filme. À chegada do Presidente da República, o General Carmona, forma-se um círculo de pessoas ao redor de seu veículo que o cumprimentam com a saudação romana. Neste momento, a locução é interrompida e uma música militar é entoada. Após o pequeno trecho musical, o locutor informa que a esposa de Carmona também esteve presente ao evento e a câmera acompanha o casal, sempre rodeados por muitas pessoas, se dirigindo à entrada do cinema. Esta sequência termina com a imagem do material de divulgação do filme, visto na Figura 14. Segue abaixo a transcrição enunciada pelo locutor:

A récita de gala oferecida pela SPAC para a estreia do novo filme português Feitiço do Império constituiu um notável acontecimento pela categoria e elegância da assistência. O realizador António Lopes Ribeiro, acompanhado pelos artistas e técnicos do filme, recebeu entre outros convidados, o Senhor Ministro da Educação Nacional e sua Excelência, o Presidente da República. A esposa do Senhor General Carmona também assistiu à estreia do Feitiço do Império, filme em que se exalta o patrimônio português em África e o nosso esforço colonizador (FANTASIA LUSITANA, 2010, 24:34 - 25:25).

O locutor informa que este evento "constituiu um acontecimento notável pela categoria e elegância da assistência”. Ora, Mann havia há pouco relatado que os refugiados que tomavam as ruas de Lisboa eram "desterrados e proscritos" e que se encontravam naquela cidade "aguardando o barco da salvação" que os levasse para longe "do inimigo que os perseguia". Após ter visto as fotografias desses refugiados e ouvido o testemunho da filha de Thomas Mann, os trajes de gala da elite portuguesa contrastam bastante com a situação daqueles estrangeiros. Começamos a notar o embate dos dois níveis de realidade apresentados por Canijo. Em suma, como a própria peça propagandística define, Feitiço do Império é um "filme em que se exalta o patrimônio português em África e o nosso esforço colonizador", quer dizer, mensagem totalmente em consonância com o mito imperial do Estado Novo.

O cinema foi utilizado pela propaganda salazarista não apenas em suas produções, mas também explorando a presença de astros e estrelas estrangeiros em terras portuguesas. A neutralidade permitiu que variadas celebridades internacionais passassem por Portugal durante a Segunda Guerra Mundial. Cada vez que isso ocorria, a propaganda salazarista aproveitava para promover o país e celebrar a paz desfrutada em seu território. 
Logo após o trecho sobre o Feitiço do Império, uma sequência com diversas filmagens de origens diferentes sobre a visita de algumas dessas "vedetas" (Figura 15) é recuperada por Fantasia Lusitana. Segue abaixo lista com os nomes das estrelas e astros presentes no documentário de Canijo, conforme são nomeados:

- Danielle Darrieux, atriz e cantora francesa, esposa de Rubirosa;

- Porfirio Rubirosa, diplomata dominicano, marido de Darrieux;

- Louis Jouvet, ator e diretor francês, marido de Ozeray;

- Madeleine Ozeray, atriz franco-belga, esposa de Jouvet;

- Robert Montgomery, ator americano;

- Annabella, atriz francesa, esposa de Power;

- Tyrone Power, ator americano, marido de Annabella;

- Simone Simon, atriz francesa;

- Jan Kiepura, ator e cantor polonês, marido de Eggerth;

- Marta Eggerth, atriz e cantora húngaro-americana, esposa de Kiepura.

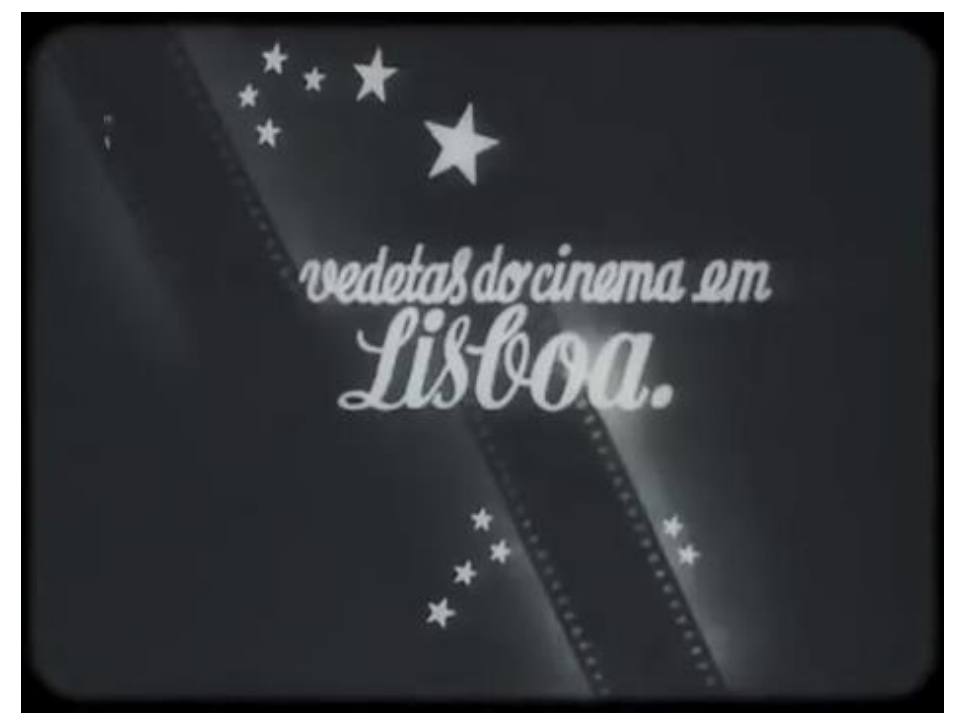

Figura 15: Intertexto que introduz a passagem de artistas por Lisboa durante a Segunda Guerra Mundial.

Esse material produzido pela propaganda salazarista, embora aparentemente tenha a intenção de informar sobre a visita desses artistas estrangeiros ao território português, acaba tendo a função de mostrar à população que Portugal era um ótimo destino, já que desfrutava do status de neutralidade durante a guerra. Havia a intenção de promover e de valorizar o país através do nacionalismo. 
Gostaríamos de destacar o texto lido pelo locutor que noticia a visita do casal Danielle Darrieux e Porfirio Rubirosa a Santarém, por ocasião de sua lua de mel:

Danielle Darrieux, vedeta [...] do cinema francês, a parisiense inconfundível, a francesinha tipo, teve durante uma visita que fez à Santarém uma recepção verdadeiramente sensacional. Acompanhada por seu marido, o diplomata dominicano Porfirio Rubirosa, passeou na cidade escoltada por uma guarda de honra de campinos, dentre os aplausos dos seus milhares de admiradores. Portugal, oásis de paz num mundo em guerra, foi o lugar eleito pelo casal Rubirosa para passar a sua lua de mel. Por isso Danielle, encantadora e encantada, sorri contentemente (FANTASIA LUSITANA, 2010, 25:26 26:05, grifo nosso).

O texto acima é acompanhado de imagens do casal Darrieux e Rubirosa sendo aplaudidos pelas ruas de Santarém, passeando pela cidade em uma charrete puxada por dois cavalos, seguida pela guarda de honra de campinos (homens vestidos à moda campesina, segurando compridos bastões de madeira que lembram lanças). A atriz utiliza uma câmera portátil para registrar imagens locais (Figura 16). A comitiva era acompanhada por um cortejo de populares, que os seguia em passos velozes. Na cena final, a câmera capta o casal entrando a pé por um portão, rodeado de pessoas que os aplaudem, formando um corredor humano.

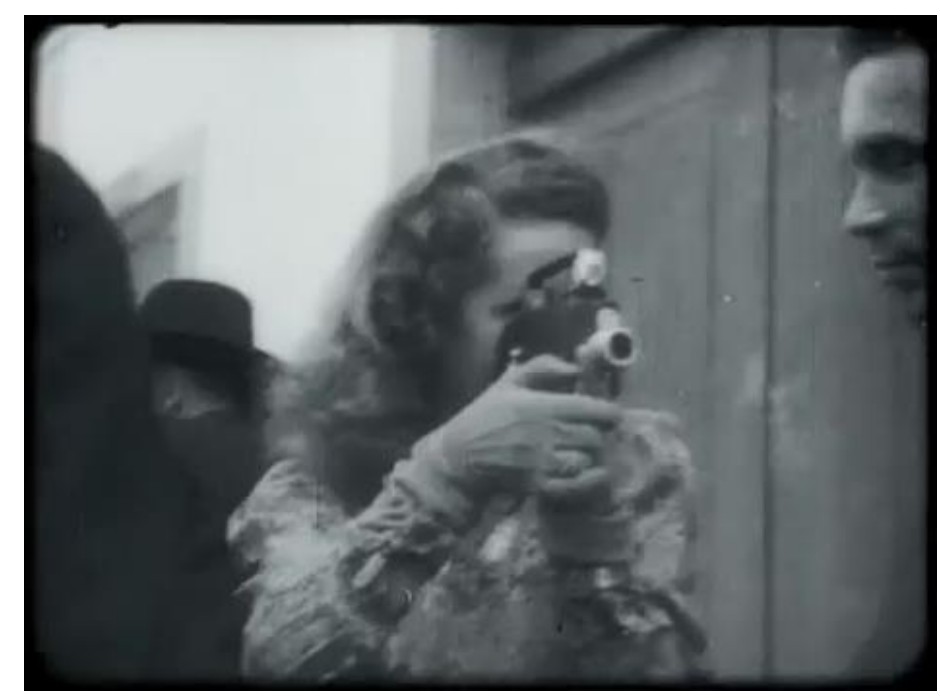

Figura 16: A atriz Danielle Darrieux filma as paisagens de Santarém em sua viagem de lua de mel.

O locutor dá destaque à maneira como o célebre casal foi acolhido naquela cidade - "recepção verdadeiramente sensacional" -, recorda a escolta feita pela guarda de honra local, toda vestida com os trajes típicos do campo e acompanhando-os a cavalo, e acentua que milhares de fãs os acompanham, ovacionando-os. Entretanto, apesar de todo o apoio demonstrado pela população de Santarém ao casal, a narração revela que o motivo que os levou a escolher aquelas terras como destino de viagem de lua de mel foi o fato de 
Portugal ser um "oásis de paz num mundo em guerra". Dessa forma, a propaganda propõe uma comparação entre Portugal e os demais países, colocando a nação lusitana numa posição de superioridade, isto é, elevando-a à condição de "oásis de paz", enquanto, no resto da Europa, há um “mundo em guerra”. Para justificar esse ponto de vista, o trecho termina explicando o motivo do sorriso da atriz em terras portuguesas: "Por isso Danielle, encantadora e encantada, sorri contentemente".

As cenas que registram as passagens dos demais artistas por terras portuguesas são muito curtas e os mostram sorrindo, acenando para as câmeras, posando para fotografias ou dando autógrafos. Acreditamos que essas imagens foram incorporadas à Fantasia Lusitana pois servem, de fato, para respaldar a ideia salazarista de que Portugal era um destino agradável, pacífico e escolhido por muitas celebridades, isto é, uma forma de autopromoção do país, e se encaixa perfeitamente na porção da camada fantasiosa relativa ao apoio da ideologia do Estado Novo.

Ainda dentro da temática do cinema, as cenas que seguem mostram um intertexto com os seguintes dizeres: "VISITANTES ILUSTRES. O "Jornal Português" entrevistou o Barão Valentin Mandelstamm, figura de grande destaque em Hollywood, que muito se interessou pelo Cinema Nacional” (FANTASIA LUSITANA, 2010, 27:19).

Em seguida, há um trecho da referida entrevista que mostra o repórter do Jornal Português entrevistando o Barão Valentin Mandelstamm, ambos em primeiro plano, e, ao fundo, vê-se um prédio em cuja fachada lê-se LISBOA FILMES. O diálogo se dá em francês, conforme a transcrição das legendas em português do documentário:

\footnotetext{
Jornal Português: O que acha das possibilidades de cinema em Portugal?

Mandelstamm: Parecem-me consideráveis. Para já, há o elemento do clima, que é absolutamente primordial e que no vosso país é quase sempre claro e ensolarado. Há também aqui tesouros históricos e artísticos muito pouco conhecidos no mundo, que oferecem, por conseguinte, a atracção da novidade. Os portugueses também têm um folclore dos mais interessantes. E, sobretudo, se posso tomar a liberdade de dizê-lo, há aqui um elemento que nos tempos actuais é dos mais importantes, a saber a tranquilidade e a calma (FANTASIA LUSITANA, 2010, 27:23 - 27:59, grifos nossos).
}

$\mathrm{O}$ fragmento da entrevista selecionado por Canijo contempla apena uma pergunta feita a Valentin Mandelstamm, e aborda a questão das "possibilidades de cinema em Portugal". O barão francês, que era versado em cinema e fazia a ponte entre a França e Hollywood referente a assuntos de cinefilia, responde de forma bastante emblemática. 
Primeiramente, a resposta do especialista versa sobre a questão do clima local, isto é, o fato de Portugal ser um país "claro e ensolarado". Depois, o entrevistado aborda assuntos relacionados ao exotismo do país, tais como sua história, arte e folclore, gerando nos estrangeiros a "atracção de novidade". Por fim, o francês toca no aspecto da neutralidade de Portugal, ao lembrar que "há aqui um elemento que nos tempos actuais é dos mais importantes, a saber a tranquilidade e a calma".

Ora, ao dizer "tempos actuais", o Sr. Mandelstamm estava se referindo à ocorrência da guerra que arruinava o resto da Europa. Dessa maneira, Portugal oferecia condições favoráveis para o cinema internacional, não por propiciar condições técnicas ou competitivas, mas pelo simples fato de não ter sido ocupado, bombardeado ou destruído como seus vizinhos europeus.

O intertexto acima transcrito informa que o visitante francês, especialista em cinema, "muito se interessou pelo Cinema Nacional". Entretanto, não nos parece que essa tenha sido a real opinião daquela autoridade. Notamos a intenção propagandística de valorizar a passagem daquele intelectual por Portugal como forma de avalizar o cinema português. Contudo, as respostas do entrevistado são evasivas, concentrando-se em motivos exóticos, que se assemelham às impressões de Döblin ou Mann acerca de Lisboa, ou na razão principal, que seria a ausência de guerra em Portugal. Nenhuma das justificativas dadas inclui a infraestrutura cinematográfica do país, ou a presença de uma participação portuguesa importante no mercado filmográfico internacional.

Por fim, talvez para exemplificar o tipo de película produzida pelo "Cinema Nacional" daquela época, Canijo inclui um trecho d'O Pátio das Cantigas (1942), filme clássico do gênero que se convencionou chamar "comédia à portuguesa". Realizado por Francisco Ribeiro, mais conhecido pela alcunha de Ribeirinho, e irmão de António Lopes Ribeiro (diretor de A Revolução de Maio e de Feitiço do Império), o excerto utilizado aborda uma briga em um estabelecimento comercial. A peleja adquire proporções que se assemelham a uma batalha, dada a presença de sons que lembram explosivos. Há, de fato, uma cena, aos 27min58s, em que alguém dispara, a partir de uma janela, com o que parece ser uma espingarda. Além disso, o personagem interpretado por Ribeirinho, após se desviar de um projétil que lhe fora lançado, surge de trás de um balcão usando um lenço branco na cabeça que pertencia ao uniforme das enfermeiras de então, o que se torna mais nítido após ele desenhar, aos 28min04s, com uma bebida que se encontrava no balcão, uma cruz na testa, por cima do lenço, o que remete à presença da enfermagem para cuidar 
dos feridos de guerra. Outro aspecto curioso é o fato de que três personagens se escondem atrás de um balcão, usando calotas de veículo na cabeça como se fossem capacetes, representando soldados se protegendo em uma trincheira (Figura 17). Em suma, o trecho d'O Pátio das Cantigas utilizado em Fantasia Lusitana faz claras alusões à guerra que acontecia no continente.

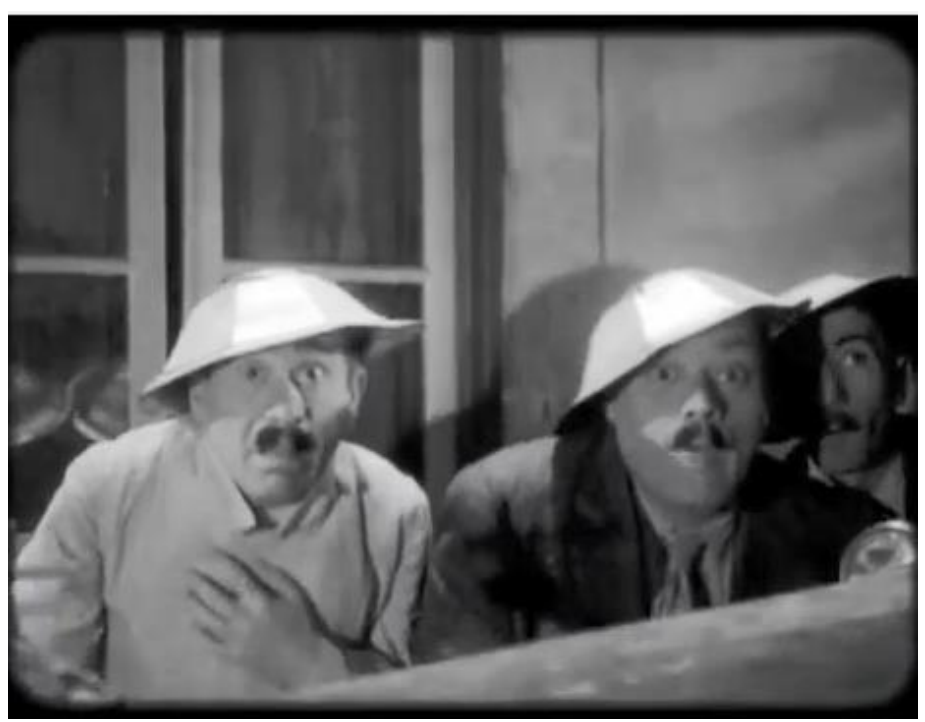

Figura 17: Imagem de $O$ Pátio das Cantigas (1942) recuperada em Fantasia Lusitana.

Em seguida, Narciso, personagem interpretado por Vasco Santana, com uma criancinha ao colo e segurando um lampião na outra mão, conduz um grupo de mais de vinte meninos e meninas até um cômodo contíguo, retirando-os daquele ambiente. Enquanto caminham, ouve-se os disparos, o que demonstra que a peleja continua muito próxima a eles. $\mathrm{O}$ adulto pendura o lampião num gancho e entrega a miúda que estava em seus braços a um garoto mais velho, que, assim como as outras crianças, se encontra em cima de um veículo de madeira que se assemelha a uma carroça. As crianças que acompanhavam o homem já haviam subido neste veículo pela parte lateral, engrossando o número daqueles pequenos fugitivos. Ao colocar a garotinha no carro, Narciso diz ao grupo infantil: "Podem estar sossegadinhos que aqui não lhes acontece mal nenhum" (FANTASIA LUSITANA, 2010, 28:24 - 28:29). Ao terminar de enunciar essas palavras, ouve-se o riso das crianças a fitar o adulto e a câmera direciona o olhar do espectador até a parte superior daquele veículo, onde se lê, ocupando cerca de trinta e cinco por cento da tela, o nome "Salazar", numa clara referência à segurança proporcionada pelo "oásis de paz” português num mundo em guerra (Figura 18). 
Nesta alusão, as crianças seriam metáfora do povo português: dóceis, sorridentes e fáceis de serem conduzidos; o adulto representaria a ideologia vigente materializada através da propaganda, que incutia no povo os ideais salazaristas; a "carroça Salazar" seria a representação do próprio ditador, que ficou renomado por poupar Portugal dos horrores da guerra, de acordo com o mito criado a esse respeito.

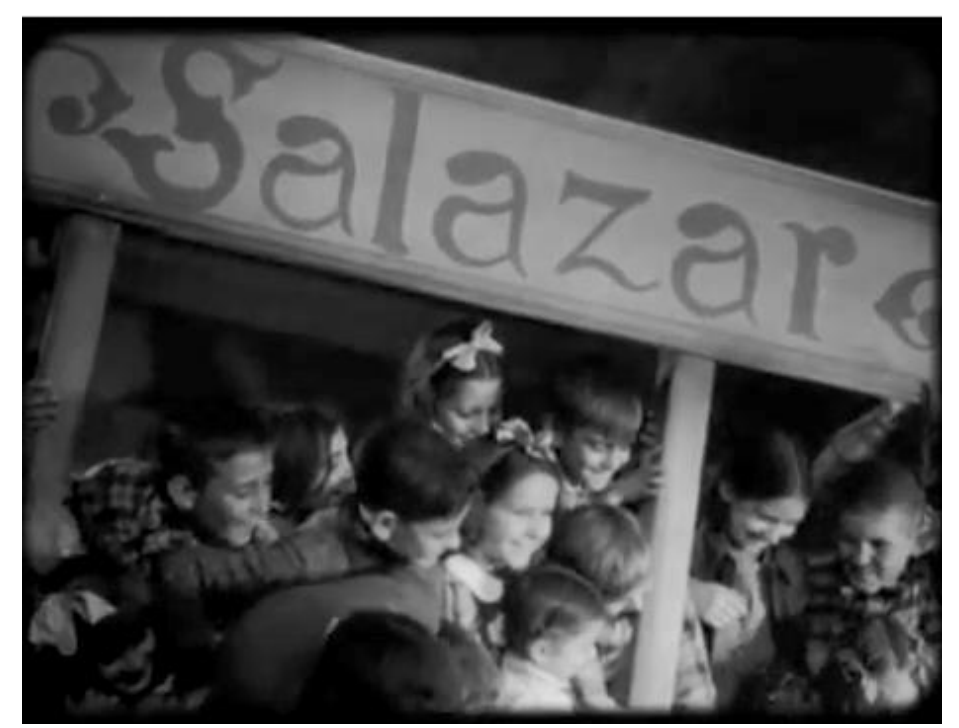

Figura 18: Imagem da “carroça Salazar” extraída do filme Pátio das Cantigas (1942), de Francisco Ribeiro, recuperada em Fantasia Lusitana.

Para o investigador Paulo Jorge Granja,

[...] a comédia à portuguesa [...] prima pela ausência de referências explícitas a acontecimentos reais, a acontecimentos «históricos», ou seja, a qualquer tipo de acontecimento social, político ou económico que pudesse lembrar o público da realidade existente fora da sala de cinema (GRANJA, 2011, p. 210).

Esta modalidade de filmes estava a serviço da hegemonia vigente, pois agia como elemento de distração aplicado às massas. Tinham a função de fazer com que a população relaxasse, se conformasse com a sua situação, e não cogitasse exigir mudanças. Segundo Granja,

Filmes de diversão, no duplo sentido de entretenimento e de desvio das atenções da realidade, estes filmes procuravam sempre [...] ocultar as realidades sócio-económicas mais incómodas para o regime, colocando o espectador «fora do mundo» (GRANJA, 2011, p. 199).

Embora os filmes pertencentes à categoria "comédia à portuguesa" tivessem o propósito de causar um sentimento de alienação na população, o próprio Granja concorda que a cena descrita acima de $O$ Pátio das Cantigas, selecionada por João Canijo para compor Fantasia Lusitana, faz referência a um acontecimento real existente fora da sala de projeção (GRANJA, 2011, p. 210). O acadêmico acredita que a forma paródica 
utilizada na película de Ribeirinho para representar a guerra de forma leve e engraçada atenua e proporciona entrar neste tema. Ademais, há também a função propagandística desta cena, que exalta a figura de Salazar. Em suma,

\begin{abstract}
[...] tudo contribui para retirar carga dramática a uma sequência que pretende evocar a guerra que então devasta a Europa. Apresentando-se o conflito desta forma, exorcizavam-se os receios de uma guerra longínqua, mas cujos efeitos não deixavam de se fazer sentir em Portugal, ao mesmo tempo que se lembrava a neutralidade que Portugal conseguira preservar e se reafirmava o bem fundado das decisões do homem que a Providência colocara à frente do destino do País (GRANJA, 2011, p. 210).
\end{abstract}

Após a cena da "carroça Salazar", Canijo nos direciona às memórias de SaintExupéry, num corte que leva o público novamente ao mundo das testemunhas da guerra, causando um choque de realidades. As imagens exibidas concomitantemente com o material acústico das anotações do aviador são do documentário A Exposição do Mundo Português (1941), um filme do Secretariado da Propaganda Nacional produzido e narrado por António Lopes Ribeiro, conforme o trecho que iremos abordar agora.

\title{
3.3 A Exposição do Mundo Português
}

A Exposição do Mundo Português foi uma mostra que ocorreu em 1940, de 23 de junho a 2 de dezembro, com o intuito de comemorar o Duplo Centenário, ou seja, a fundação e a restauração de Portugal conforme temos abordado. Mais do que isso, tal feira representou um marco para o Estado Novo, pois personificou o ideário do regime através da exibição de alguns temas caros à ideologia salazarista, consoante os mitos ideológicos fundadores do Estado Novo cunhados por Fernando Rosas (2001).

Inaugurada em plena Segunda Guerra Mundial na freguesia lisboeta de Belém, esta exposição conjugou, em um único espaço, vários símbolos que expressavam a história de Portugal tecida pelo viés ideológico do regime, englobando alguns pavilhões temáticos. Podemos resumir as várias atrações em três pequenos blocos:

1) Figuras históricas do passado, como reis, cavaleiros, navegadores e exploradores, representando a expansão territorial do país, tal como as guerras de reconquista, e a dilatação do império e da religião católica pelo mundo;

2) Os usos e costumes do povo português traduzidos na celebração da portugalidade, isto é, no traço comum que unia a todos, não obstante o caráter único de cada região, tal como vestuário, danças, música, atividades típicas, entre outros; 
3) O território português de além-mar em sua contemporaneidade, incluindo as colônias africanas e asiáticas, suas gentes e seus costumes.

O pesquisador Sérgio Alexandre Gomes (2006-2007) resume o conteúdo da exposição em "três conjuntos temáticos: o da História, o da Etnografia Metropolitana e o da Etnografia Colonial que [...] é explicado como o resultado da vocação universalista do povo português e, como tal, símbolo de união" (GOMES, 2006-2007, p. 204).

As cenas do cinejornal de Lopes Ribeiro utilizadas em Fantasia Lusitana retratam esses três aspectos. O excerto inicia com algumas imagens panorâmicas do local da exposição, com o Rio Tejo ao fundo. Em seguida, mostra a chegada de visitantes ao local, um parque de diversões e pessoas que se divertem. A câmera adentra então o ambiente onde se encontram os pavilhões, e, sempre em plano aberto, procura captar a suntuosidade do local através das várias edificações. Ouve-se então a locução de Lopes Ribeiro acerca da inauguração do evento, quando imagens do General Carmona e de Salazar são exibidas:

\begin{abstract}
A maravilhosa exposição foi inaugurada a 23 de junho de 1940 pelo português mais digno de tal acto, o Senhor General Carmona, Presidente da República Portuguesa. E a seu lado estava o homem que a tornou possível, o verdadeiro arquitecto do Portugal de hoje, novo e eterno, Salazar. Enquanto o resto da Europa se debatia numa guerra cruenta, a festa jubilar de Portugal oferecia a todo o mundo o exemplo da nossa disciplina e da paz que soubemos merecer (FANTASIA LUSITANA, 2010, 30:16 - 30:30).
\end{abstract}

A transcrição acima evoca a figura dos Chefes da Nação, que geralmente são mencionados e exibidos um próximo ao outro (Figura 19). Se por um lado Carmona desempenha o papel figurativo, como desfraldar a bandeira que inaugura a exposição, por outro, Salazar recebe os louros pela concretização da exposição, uma vez que o cinejornal de Lopes Ribeiro enfatiza que ele é "o homem que a tornou possível". Ademais, ele também é reconhecido como o "arquitecto do Portugal de hoje, novo e eterno", numa alusão não só àquela mostra, mas também às benfeitorias que vinham sendo feitas no país.

Aliás, na maioria do material fílmico produzido pela propaganda naquela época de consolidação do Estado Novo, Carmona é retratado vestindo o seu uniforme militar, sorrindo e acenando para a população ao passo que a câmera sempre capta um Salazar mais comedido e discreto. É o que explica a pesquisadora Heloísa Paulo:

Nestes primeiros anos de governo, conformando o seu sacrifício pessoal pela «Nação», Salazar é a figura de um homem sério, de roupas austeras e negras, que sorri discretamente, em ocasiões excepcionais, quando o contacto com o público o exige. Na maioria das cenas, fotografadas ou filmadas, o seu rosto é 
austero, buscando expressar o sacrifício pessoal do antigo professor de Coimbra. A sua imagem contrasta com a de Carmona, o militar sorridente, com um ar sempre despreocupado, expressão da sua função decorativa no Governo. Os «ídolos do povo», como são designados num documentário do SPN, datado de 1936, são figuras que se contrapõem, revelando um jogo de imagens, no qual Salazar ganha gradualmente um maior destaque (PAULO, 2011, p. 114, grifos nossos).

Além disso, o excerto do documentário propagandístico relembra a existência da guerra nos outros países europeus e reforça a condição neutral de Portugal. A neutralidade portuguesa era vista como algo irrepreensível e modelar. Dessa forma, infere-se que os países envolvidos no conflito eram detentores de valores negativos, como não gozar de disciplina ou paz, uma vez que não as souberam merecer, revelando um juízo de valor em prol de Portugal.

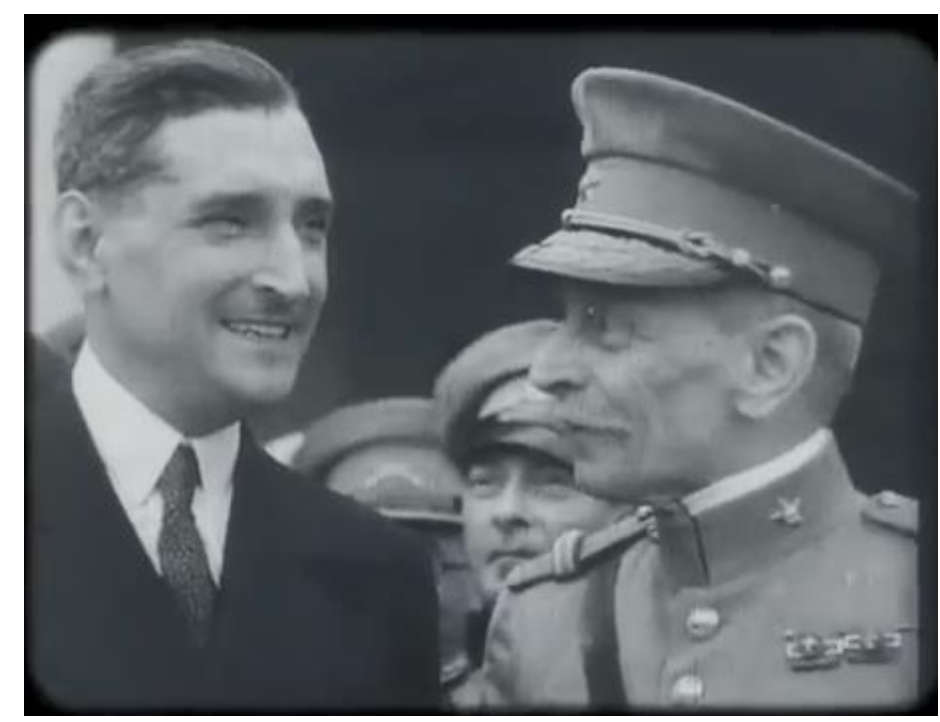

Figura 19: Salazar e Carmona na inauguração da Exposição do Mundo Português.

Após duas tomadas com frases de impacto presentes na Exposição do Mundo Português - "Estudar com dúvida e realizar com fé - Salazar" (FANTASIA LUSITANA, 2010, 30:45) e "Equilíbrio Financeiro. Portugal, país de boas contas" (FANTASIA LUSITANA, 2010, 30:47) - há uma imagem onde se lê "Centro Regional - Vida Popular" (FANTASIA LUSITANA, 2010, 30:52) na entrada do que parece ser um pavilhão, e ouve-se uma música alegre, tipicamente regional.

A partir de então, uma série de imagens de homens e mulheres trajados com roupas típicas das mais variadas regiões do país são exibidas. Eles são retratados dançando músicas regionais (Figura 20), executando trabalhos manuais, ou agindo de modo "natural", como se estivessem em suas aldeias. Todas essas atividades ocorrem numa espécie de vilarejo artificial que emula as localidades originais, procurando-se copiar a 
arquitetura local de cada aldeia. De acordo com Francisco Martinho, "O projeto cultural do salazarismo procurou uma 'restauração sistemática dos valores da tradição'. Conseqüentemente maior atenção foi dada a temas de caráter etnográfico e folclórico que passou por uma verdadeira revitalização" (MARTINHO, 2007, p. 24).

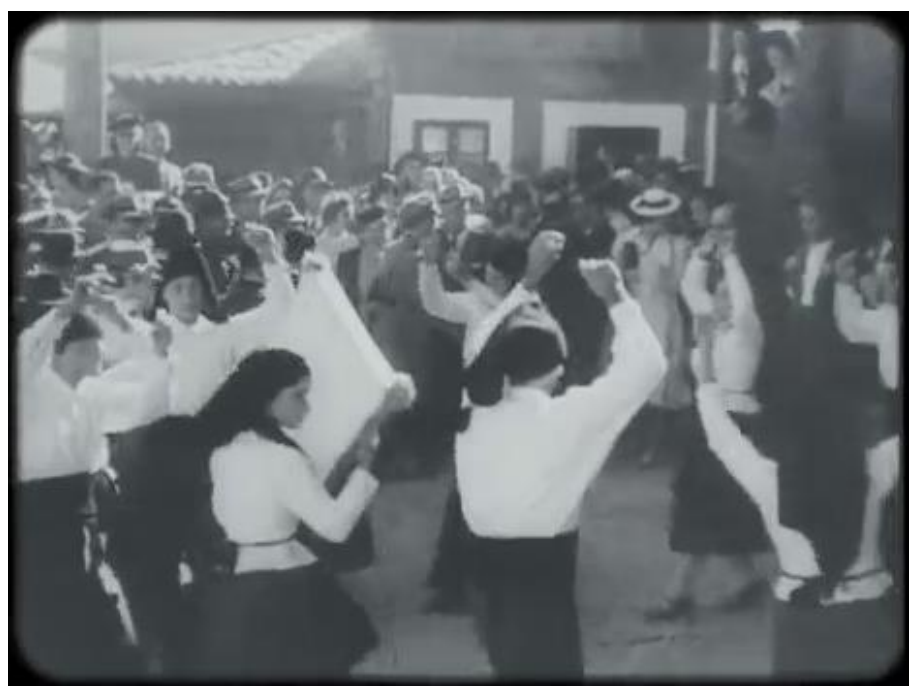

Figura 20: Grupo de pessoas vestidas a caráter dançam o Vira no Centro Regional da Exposição do Mundo Português.

Os organizadores do Centro Regional tiveram a preocupação de reproduzir não apenas os hábitos e costumes das pessoas de cada localidade, mas também de apresentar réplicas arquitetônicas pitorescas, o que poderia ser entendido como a celebração da portugalidade. Muito embora diferentes em sua forma de expressão, todos os representantes daquela seção carregavam em si um elemento aglutinador comum, isto é, "a essência lusitana", no entender da ideologia de governo vigente.

Esta tentativa artificial de se criar uma natureza portuguesa vinha sendo construída pelo regime desde antes dessa exposição. Gomes revela que

Neste sentido são postas em prática uma série de medidas de preservação e promoção da cultura popular - conhecidas como a Política do Espírito -, entre as quais é de destacar o concurso A Aldeia mais portuguesa de Portugal [...], do qual saiu vencedora a aldeia de Monsanto (Idanha-a-Nova, Castelo Branco). (GOMES, 2006-2007, p. 205).

O pesquisador explica que "a aldeia e os modos de vida rurais são tomados como a parte integrante da identidade nacional, sendo perspectivados como fonte da essência da nação" (GOMES, 2006-2007, p. 206), o que justifica a criação do Centro Regional na Exposição do Mundo Português.

Em suma, para justificar o golpe militar de 1926 e a consequente instituição da nova ordem, Gomes esclarece que "É neste equacionamento da identidade da nação que 
o Estado Novo legitima a sua acção de reaportuguesamento de Portugal" (GOMES, 2006-2007, p. 206), isto é, "são estes os valores que, segundo o regime, interessa [sic] promover no sentido de salvar a nação da degenerescência que levou à instauração da ditadura" (GOMES, 2006-2007, p. 206).

A religião católica foi outro elemento valorizado nos pavilhões do Centro Regional naquela feira, já que, para o regime, devia ser um elemento partilhado por todos. Observemos a transcrição abaixo, presente no excerto em análise:

Dançava-se e cantava-se a valer ali mesmo ao pé, nas aldeias do Centro
Regional, verdadeiro brinquedo da exposição, resumo de tudo que há de mais
bonito e alegre e pitoresco por este Portugal além. Gentes vinda do Minho, do
Algarve, do Alentejo, de Trás-os-Montes e das Beiras, enchiam de vida
aquelas graciosas ruas e casas tiradas pelo natural, réplica fiel das autênticas
ruas e casas portuguesas. Toda a gente das aldeias vivia na exposição de Belém
a sua vida habitual, ia à igreja rezar a Ave-Maria, ia à fonte encher a
cantarinha (FANTASIA LUSITANA, 2010, 30:55 - 31:38, grifos nossos).

O sentimento de portugalidade foi fomentado ao se trazer pessoas de todas as regiões do país para representarem os seus próprios papeis, isto é, desempenhar atividades corriqueiras a seu modo, a fim de que os visitantes compreendessem a riqueza da diversidade nacional. Embora cada região tivesse as suas peculiaridades, todos iam "à igreja rezar a Ave-Maria” (Figura 21), ou seja, assumia-se que todos os portugueses eram católicos praticantes, o que conferia ao catolicismo a condição de elemento de coesão, corroborando o mito da essência católica da identidade nacional apregoado pelo regime.

Mais do que isso, a propaganda salazarista se baseava em mitos religiosos para explicar fatos históricos, fazendo com que Igreja e Estado caminhassem alinhadamente. A esse espeito, Gomes assevera que "Esta justaposição da religião cristã e da história nacional é uma constante na propaganda política. Com efeito, o regime reaviva uma série de mitos acerca da intervenção divina em episódios históricos, bem como estabelece uma íntima conexão com a Igreja Católica” (GOMES, 2006-2007, p. 203).

No entanto, ao utilizar a religião para explicar a história,

o Estado, enquanto Nação, passa a ser o mediador entre a divindade e o crente, o acesso à felicidade prometida por Deus é o projecto da Nação, o verdadeiro crente é o cidadão exemplar, isto é, aquele que põe a Nação acima de todas as prioridades porque é essa atitude que lhe permite alcançar Deus e, por conseguinte, viver num regime de verdade e ser digno de felicidade (GOMES, 2006-2007, p. 215).

Com relação à ruralidade portuguesa, Heloísa Paulo reflete acerca de vários documentários alinhados às ideologias do Estado Novo daquela época que exploravam 
essa temática. Essas películas retratavam a população camponesa vestindo trajes típicos e eram produzidas para convencionar uma imagem artificial e romanceada do país:

É neste género de produção que podemos ver como é forjada a imagem ideal do País, possuidor de uma história igualmente idealizada, com uma vida predominantemente rural e com habitantes tipificados através de seus trajes e costumes regionais. Da mesma forma, é passada a mensagem política do regime, os valores pensados para a «Nação» e o seu «culto», a imagem da verdadeira cidadania, exemplificada por aqueles que aderem ao Estado Novo, e a figura do mito do chefe, centrado na figura de Salazar (PAULO, 2011, p. 108).

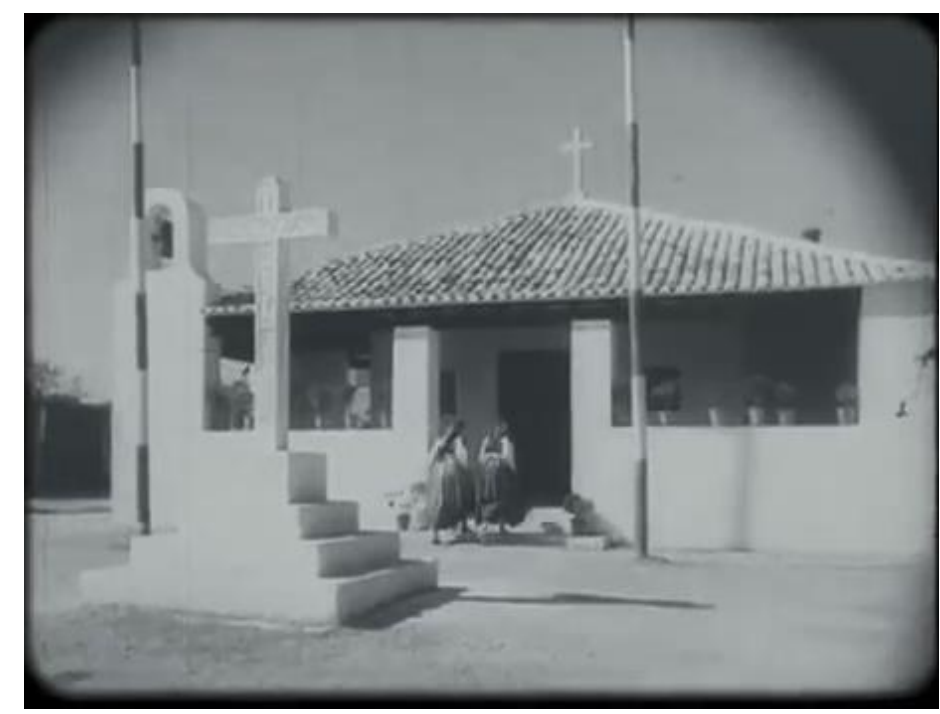

Figura 21: Mulheres usando trajes típicos adentram uma igreja numa réplica de aldeia, no Centro Regional da Exposição do Mundo Português.

Após as imagens do Centro Regional, o documentário de Canijo apresenta cenas do Cortejo Histórico do Mundo Português, que, conforme o próprio nome diz, foi um desfile contendo representações das figuras históricas de Portugal desde a sua fundação até aquele momento. Cavaleiros medievais montados em cavalos devidamente ornamentados carregam bandeiras; pessoas vestindo roupas dos últimos oitocentos séculos desfilam, empunhando estandartes; um carro alegórico chamado Carro Educativo da Lusitânia exibe uma mulher que segura uma lança e um escudo, a frente dos primeiros versos de Os Lusíadas, como se fosse a guardiã da língua portuguesa (Figura 22); figuras históricas, tais como alguns dos grandes exploradores marítimos, fixam o olhar na câmera (Figura 23); um elefante adornado simbolizando aquele presenteado ao Papa Júlio II pelo Rei D. Manuel I no século XVI, e um leão, que parece estar sedado, são exibidos; por fim, um grupo de judeus e outro de mouros são flagrados pela câmera. 


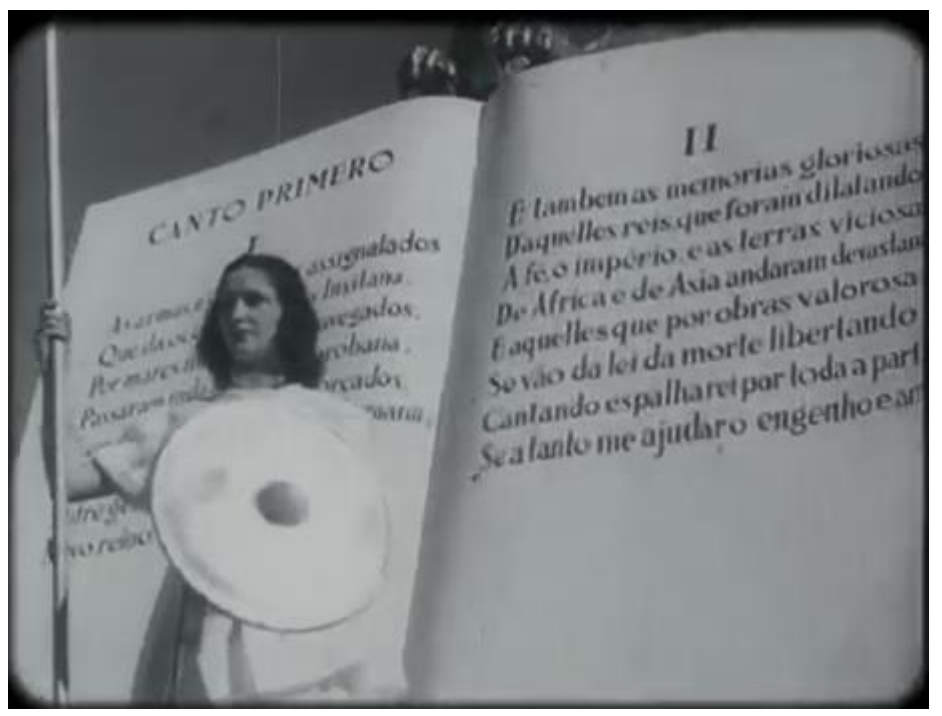

Figura 22: Detalhe do Cortejo Histórico do Mundo Português. Mulher segura espada e escudo a frente da representação de $O s$ Lusíadas.

As cenas do Cortejo Histórico do Mundo Português presentes em Fantasia Lusitana procuram apresentar um amálgama contínuo entre o passado e o presente salazarista, ocultando as derrotas da nação e focando apenas nos fatos gloriosos. Segundo o pesquisador Francisco Martinho, "Durante toda a construção da ideologia salazarista, buscar-se-á [...] o resgate da 'verdadeira' história de Portugal” (MARTINHO, 2007, p. 20), desde que essa "verdade histórica" endosse a ideologia do regime.

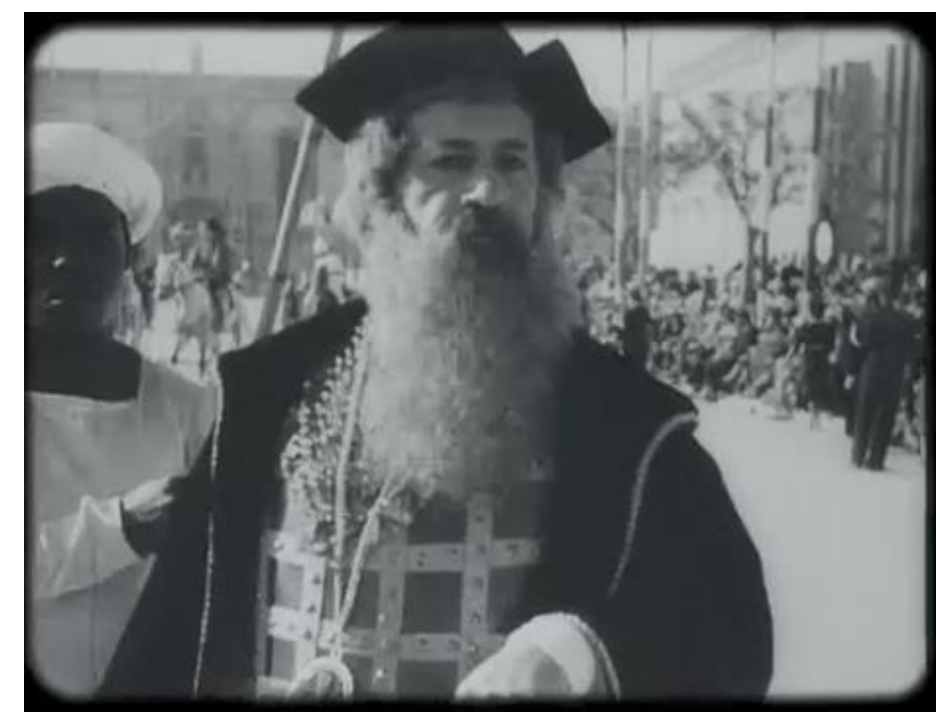

Figura 23: Figurante do Cortejo Histórico do Mundo Português trajado a caráter encara a câmera. Ao fundo, se vê a presença de outro figurante que representa um criado ou escravo.

Por fim, a última sequência das cenas da Exposição do Mundo Português no documentário de Canijo realça as populações das colônias que foram trazidas para aquela feira, numa espécie de zoológico humano, para que os visitantes pudessem vê-los em 
ambientes que foram construídos para representar suas habitações originais. O cinejornal de Lopes Ribeiro insiste na ideia da vocação natural portuguesa de colonização. O propagandista, que também faz a locução do seu documentário, lê uma das frases expostas na exposição: "Quando Portugal nasceu, fundou-se a nação que maior influência teria no mundo" (FANTASIA LUSITANA, 2010, 33:09 - 33:12). Portanto, a exibição de pessoas provenientes das colônias naquela feira parece querer corroboram essa frase.

Nesta perspectiva, o espectador vê mulheres negras saindo da "Igreja das Missões (Figura 24), erguida no centro colonial da exposição, e onde todos os dias os indígenas vindos propositadamente dos quatro cantos do império ouviam missa" (FANTASIA LUSITANA, 2010, 33:15 - 33:24). Mais uma vez, a religião é usada como a argamassa que une as populações da metrópole e das colônias - embora, neste último caso, ela tenha se dado por meio de conversões, na maioria das vezes forçadas. De toda forma, percebese a construção da imagem de Portugal como país desenvolvido e exemplar, que tinha por missão levar a civilização, a religião e os valores portugueses àquelas pessoas consideradas inferiores.

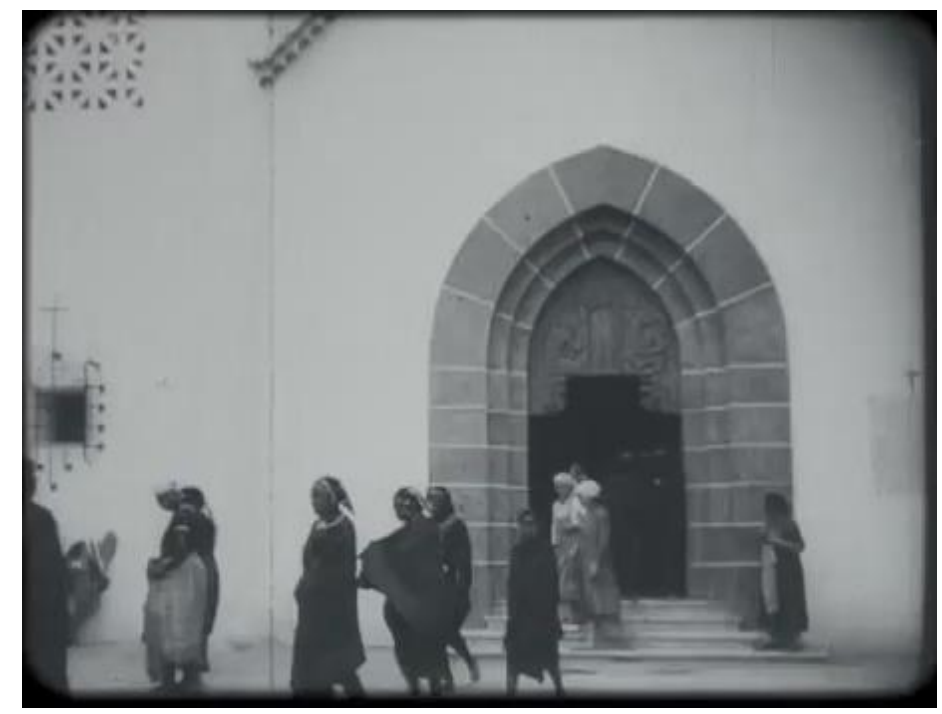

Figura 24: Mulheres das colônias africanas deixam a Igreja das Missões, construída na Exposição do Mundo Português.

Ainda dentro da temática religiosa, a Exposição do Mundo Português se propôs a reproduzir de que forma o catolicismo era espalhado pelas colônias portuguesas de alémmar. Ambientes que simulavam os domínios africanos eram construídos para demonstrar como se dava o trabalho das missionárias: "Irmãs de caridade continuavam ao vivo sua acção humaníssima ensinando os negros do centro colonial, que os visitantes podiam ver 
vivendo a sua vida quotidiana, no ambiente nas habitações apropriadas" (FANTASIA LUSITANA, 2010, 33:26 - 33:39).

Percebe-se, no excerto acima, a importância de querer mostrar aos visitantes de que maneira ocorria esse trabalho de conversão, classificado como "ação humaníssima". Na perspectiva do Estado Novo, a melhor opção para os habitantes das colônias era aderir ao modelo português, quer educacional, religioso ou moral, anulando todos os valores culturais inerentes àquelas comunidades. As freiras estão "ensinando os negros" (Figura 25), ou seja, é uma via de mão única, onde o conhecimento flui apenas de um lado. Não se concebia haver um intercâmbio de conhecimento, uma vez que a cultura dos povos locais era vista como primitiva, exótica, ou digna de ser apenas exposta, como retratam as cenas da Exposição do Mundo Português.

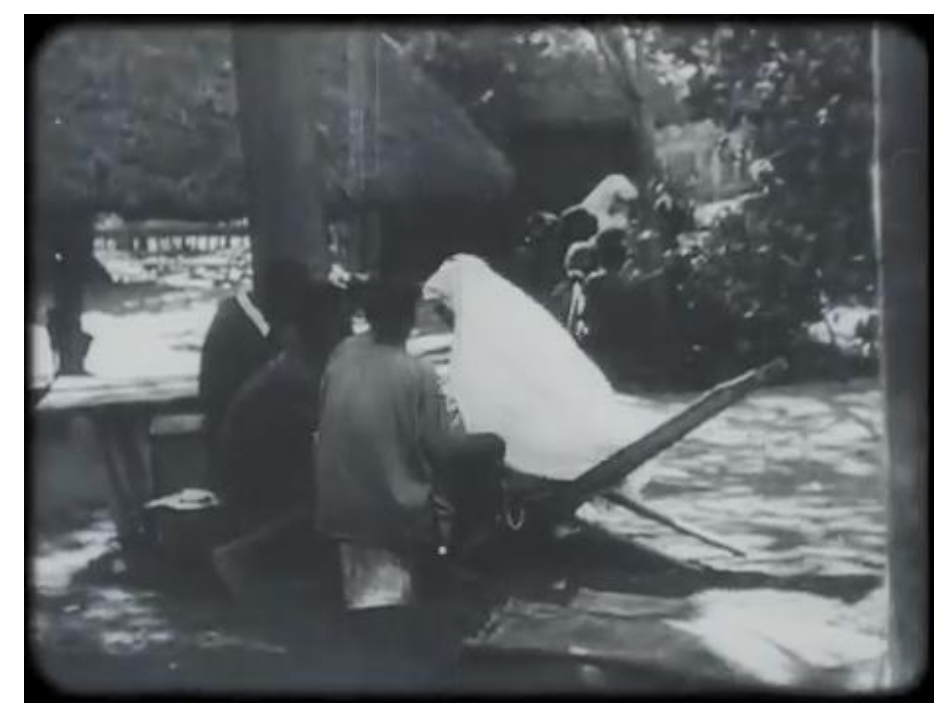

Figura 25: Freiras portuguesas ensinam grupos de jovens africanos numa reprodução de uma aldeia colonial.

Nos dias de hoje, a exibição de seres humanos em um evento é algo que nos causaria mal-estar, porém, em 1940, em plena consolidação do Estado Novo, expor pessoas numa feira pelo simples fato de serem diferentes física e culturalmente, mas, sobretudo, por serem procedentes de terras exploradas pelos portugueses (Figura 26) parece que era bem aceito. Por um lado, os visitantes eram atraídos pela diversidade que essas pessoas apresentavam, sejam em seus biotipos, vestimentas ou costumes. Por outro, o regime incutia na população a ideia de que Portugal era um país prestigioso por possuir terras tão distantes da Europa, conquistadas com a bravura de seus homens de outrora. 


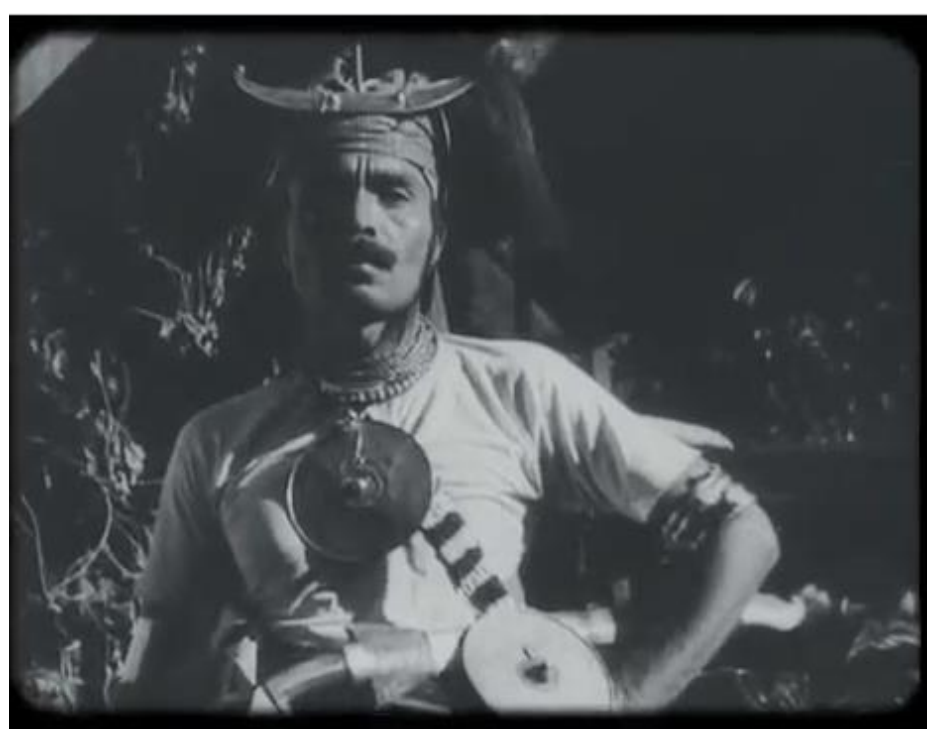

Figura 26: Homem proveniente do Timor faz parte do "acervo" da Exposição do Mundo Português.

Em suma, a Exposição do Mundo Português foi utilizada como plataforma de fortalecimento e expansão das ideias do Estado Novo através da propagação de sua ideologia. Muito embora se comemorasse o Duplo Centenário em 1940, optar por se levar adiante a construção e inauguração de um evento grande e portentoso como esse, sabendo que a Segunda Guerra Mundial havia começado oficialmente no ano anterior, foi uma escolha questionável, mas interessante ao regime.

Dentro desta argumentação, o investigador Sérgio Sá explica que:

[...] numa Europa em guerra, o realce [foi] dado ao 'paraíso' que era Portugal, onde as pessoas podiam circular, passear e divertir-se à vontade. Como é óbvio, os destinatários principais desta mensagem eram os portugueses, sendo o objectivo fazer-lhes ver a óptima situação em que estavam por comparação com o resto da Europa, tudo devido a Salazar, naturalmente: a propaganda estava fundamentalmente virada para dentro e o espectáculo funcionava sobretudo como glorificação do regime (SÁ, 2013, p. 263-264).

É justamente esse estratagema utilizado pela propaganda salazarista (não me refiro apenas à exposição de Belém, mas à toda política aplicada nas décadas de trinta e quarenta do século XX, resumidas nos Mitos Ideológico Fundadores do Estado Novo) o que Canijo pretende denunciar ao apresentar uma montagem que dá voz ora ao nível propagandístico, ora ao nível dos três refugiados.

Para efeitos de organização, os capítulos 2 e 3 desta dissertação abordaram essas duas camadas de forma separada, conforme já havíamos mencionado, porém, dentro da diegese de Fantasia Lusitana, elas passam a se intercalar a partir dos 19min03s, chamando a atenção do espectador aos dois níveis recuperados. No capítulo 2, analisamos 
o ponto de vista de Döblin, Mann e Saint-Exupéry acerca de Portugal, enquanto no capítulo 3 abordamos a esfera da propaganda, sobretudo no mundo cinematográfico e na Exposição do Mundo Português.

Cada vez que uma dessas camadas é interrompida para dar lugar a outra, ocorre um contraste, dado o teor antagônico entre elas. Na camada referente às reflexões do trio de estrangeiros, o que predomina é a gravidade dos assuntos relativos ao mundo da guerra, como a dor, a incerteza e o medo. Esses refugiados comparam a cidade que os acolhe com a realidade dos países ocupados de onde fugiram, percebendo a fragilidade portuguesa e não compreendendo o clima alegre e festivo daquela nação ao mesmo tempo em que há uma guerra em curso no resto da Europa. Ouvir esses pensamentos na própria língua em que foram escritos e ver as imagens que representavam o que eles viram faz com que o público sinta empatia pela dor desses desterrados.

Entretanto, quando a montagem "expulsa" o espectador daquela condição, levando-o, abruptamente, ao mundo da propaganda salazarista ocorre um grande impacto, já que os assuntos são geralmente rasos, ou até mesmo fúteis, como a passagem de celebridades por Portugal. Muito embora essa estratégia de oscilação entre as duas camadas ocorra outras vezes na película, não iremos mais nos estender nessa análise, pois se tornaria improfícua. Passaremos, assim, a analisar outras estratégias de montagem propostas por Fantasia Lusitana que também acabam por desconstruir a propaganda salazarista. 


\section{CAPÍTULO 4: A DESCONSTRUÇÃO DA FANTASIA}

Passaremos agora à análise da montagem de Fantasia Lusitana. Como se sabe, nenhum filme é imparcial ou isento. Segundo Ismail Xavier (2003), há duas razões para que isso ocorra. Primeiramente, há que se levar em conta o papel do realizador, uma vez que "Toda montagem é discurso, manipulação, seja de Eisenstein, de Griffith ou de Buñuel" (XAVIER, 2003, p. 46), ou seja, para o acadêmico, o processo de realização de uma película está carregado das ideias, do ponto de vista, isto é, da perspectiva de seu diretor, fazendo com que nenhum filme seja classificado como neutro.

Por outro lado, Xavier (2003) também considera o papel ativo e atento do espectador, isto é, do sujeito observador, na decodificação de uma imagem, seja ela uma imagem fixa ou em movimento. A esse respeito, o professor explica que

Toda leitura de imagem é produção de um ponto de vista: o do sujeito observador, não o da "objetividade" da imagem. A condição dos efeitos da imagem é essa. Em particular, o efeito da simulação apóia-se numa construção que inclui o ângulo do observador. O simulacro parece o que não é a partir de um ponto de vista; o sujeito está aí pressuposto. Portanto, o processo de simulação não é o da imagem em si, mas o da sua relação com o sujeito (XAVIER, 2003, p. 51).

Dessa forma, considerando o projeto de João Canijo ao realizar Fantasia Lusitana e contando com o papel ativo do espectador na interpretação do documentário, pretendemos analisar de que modo a montagem desta película promove a desconstrução da propaganda salazarista em várias instâncias.

As imagens utilizadas nesta obra, quer seja material fílmico produzido pelo próprio regime, quer seja material fotográfico da época que foi posteriormente coletado, são organizadas de modo a construir significado. Isso também se aplica ao material auditivo presente no documentário. Dessa forma, a seleção e a montagem de todo esse material, que recebeu o aval de Canijo, passa a ser decodificada pelo espectador atento, gerando significação.

É pertinente lembrar que, embora sendo um filme, Fantasia Lusitana pertence ao gênero documentário. Dentro desse gênero, o investigador Bill Nichols (2013) afirma que "A lógica que organiza um documentário sustenta um argumento, uma afirmação ou uma alegação fundamental sobre o mundo histórico" (NICHOLS, 2013, p. 55). Sendo assim, seria correto afirmar que Canijo se propôs a fazer um recorte factual na história de Portugal, isto é, os anos do regime salazarista em que se deu a Segunda Guerra Mundial, 
e traçar um paralelo entre as políticas daquele governo e os países envolvidos ou afetados por aquele conflito. Dessa maneira, o cineasta logra criticar não apenas a postura alienadora do Estado Novo diante daquela catástrofe humanitária, mas também a ideologia que formou a sua base.

Ao comparar filmes de ficção e documentários, Nichols (2013) elucida que a montagem em ambos os gêneros ocorre de forma diferente. O teórico classifica a montagem do primeiro como sendo "montagem em continuidade, [pois] opera para tornar invisíveis os cortes entre as tomadas" (NICHOLS, 2013, p. 55-56), a fim de que o expectador se envolva naquele "mundo imaginário". Em contrapartida,

[...] aquilo que a continuidade consegue na ficção é obtido no documentário pela história: as situações estão relacionadas no tempo e no espaço em virtude não da montagem, mas de suas relações reais, históricas. A montagem no documentário com frequência procura demonstrar essas ligações [...]. Portanto, o documentário apoia-se muito menos na continuidade para dar credibilidade ao mundo a que se refere do que o filme de ficção (NICHOLS, 2013, p. 56).

Assim sendo, percebemos que o apagamento proporcionado pela "montagem em continuidade" em filmes de ficção não ocorre em documentários porque a história em si funciona como elemento de fidedignidade, uma vez que "suas ligações estão relacionadas no tempo e no espaço". Logo, neste último gênero, não existe a preocupação em se ocultar a montagem. Em suma, referente a documentários, "De maneira alguma o corte perturba a sequência embora não haja continuidade espacial ou temporal entre [...] duas tomadas" (NICHOLS, 2013, p. 57).

De fato, percebemos que a montagem de Fantasia Lusitana apresenta inúmeros cortes, os quais oscilam entre aquilo que chamamos de nível da propaganda salazarista e nível dos refugiados de guerra. Ainda a esse respeito, Nichols (2013) lembra que:

com frequência, o documentário exibe um conjunto mais amplo de tomadas e cenas diversificadas do que a ficção [...]. Os personagens, ou atores sociais, podem ir e vir, proporcionando informação, dando testemunho, oferecendo provas. Lugares e coisas podem aparecer e desaparecer, conforme vão sendo exibidos para sustentar o ponto de vista ou a perspectiva do filme. Uma lógica de implicação faz a ponte entre esses saltos de uma pessoa ou lugar para outro (NICHOLS, 2013, p. 56-57).

É justamente isso que notamos no documentário de Canijo, pois da mesma forma que o casal Danielle Darrieux e Porfirio Rubirosa surge na película de forma inesperada, eles desaparecem. O mesmo fenômeno se dá com a cidade de Santarém onde estão em lua de mel, com a Exposição do Mundo Português, ou com as participações testemunhais de Döblin, Mann e Saint-Exupéry. Tudo e todos surgem e saem de cena de maneira 
imprevisível, desavisada, sem, no entanto, deixar de cumprir o seu papel. Estes são apenas alguns exemplos extraídos de Fantasia Lusitana que corroboram a explicação dada pelo teórico americano. Entretanto, é bom destacar o propósito existente por trás deste tipo de montagem, que, segundo Nichols (2013), serve para "sustentar o ponto de vista ou a perspectiva do filme”, conforme já mencionamos em relação a Canijo.

Dessa forma, em oposição à chamada "montagem em continuidade" nos filmes de ficção, Nichols (2013) chama a montagem em documentários de

"montagem de evidência". Em vez de organizar os cortes para dar a sensação
de tempo e espaço únicos, unificados, em que seguimos as ações dos
personagens principais, a montagem de evidência organiza-os dentro da cena
de modo que se dê a impressão de argumento único, convincente, sustentado
por uma lógica [...]. [Assim,] duas tomadas podem ter sido feitas com um
intervalo de anos ou mesmo em continentes diferentes, mas contribuem para a
representação de um processo único e não para o desenvolvimento de um
personagem individual" (NICHOLS, 2013, p. 58).

Passaremos agora a analisar alguns excertos específicos da película a fim de demonstrar como a montagem se traduz em elemento primordial para a desconstrução da propaganda salazarista.

\subsection{As imagens escolhidas para corroborar as falas estrangeiras}

Dentre o material fílmico de arquivo selecionado para compor Fantasia Lusitana, vários trechos foram cuidadosamente escolhidos com o intuito de serem utilizados em conjunto com os testemunhos dos três estrangeiros que passaram por Lisboa em 1940.

Pelo fato de Döblin, Mann e Saint-Exupéry terem deixado suas memórias acerca do período em que estiveram em Portugal em forma de texto escrito, a solução encontrada pelo realizador foi a contratação de atores cujos idiomas eram os mesmos das três ilustres testemunhas a fim de rememorarem e interpretarem as mesmas sensações e sentimentos vividos naquela época, conforme vimos no capítulo 2 deste estudo.

Entretanto, a fim de respaldar o que era dito pelas testemunhas estrangeiras, a montagem, em alguns trechos, teve o cuidado de escolher cenas que enfatizassem o que era expresso, gerando coincidência entre o que se ouve e o que vê. Isso pode ser comprovado nas legendas em língua portuguesa que se encontram na tela, o que se torna um expediente didático, porém, não verídico, por não representar de fato o que as testemunhas viram ou vivenciaram. Embora essa técnica seja empregada amiúde no 
documentário, optamos por analisar apenas um aspecto dessas ocorrências para cada um dos três estrangeiros.

Começamos com um trecho anotado por Alfred Döblin. Ao comparar Lisboa com as cidades francesas que estavam sob o jugo nazista, o médico alemão enfatiza o estranhamento experimentado por ele ao perceber o calor meridional, as luzes, as músicas e os ruídos nas ruas lisboetas. A partir dos 20min06s, a testemunha começa a relatar impressões acerca da capital portuguesa enquanto se dirigia ao hotel onde se hospedaria. Em um determinado momento, imagens de um baile noturno a céu aberto são exibidas, revelando centenas de pessoas que se aglomeram para assistir os poucos casais que conseguem espaço para dançar. Ouve-se o som da música original ao fundo, coberta pelos relatos do refugiado alemão, em destaque.

Döblin diz que ele conseguia ouvir a música do baile a partir de seu quarto de hotel, logo, deduz-se que ele não tenha ido ao referido evento, uma vez que tinha acabado de chegar a Portugal proveniente da França. Porém, a imagem exibida (Figura 27) a fim de corroborar a fala do médico é a que vemos abaixo, em cuja legenda se lê "A divertida música de baile que invadia as ruas".

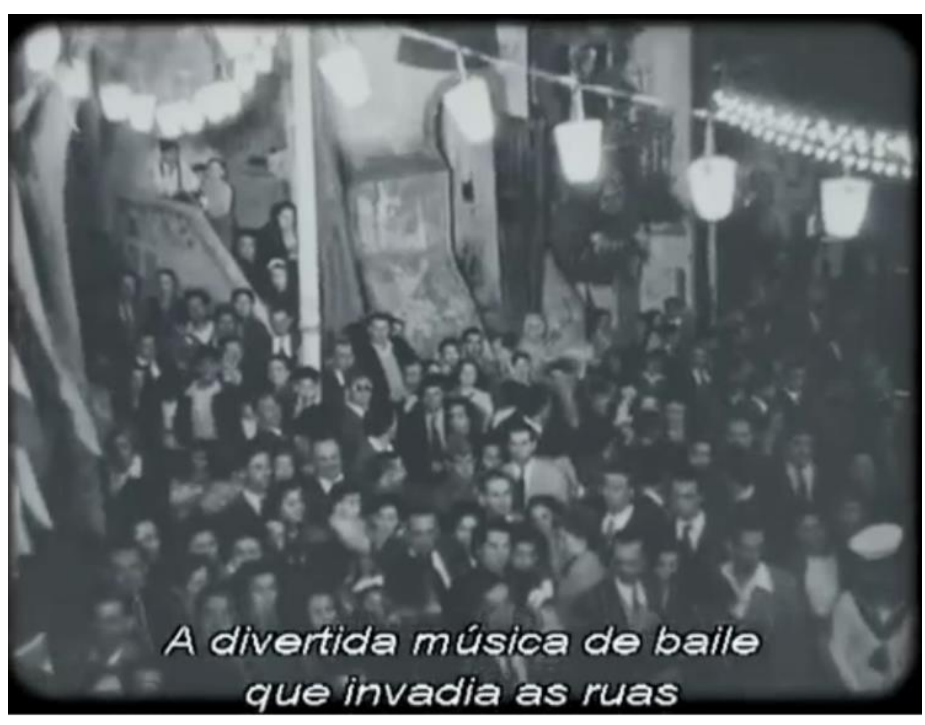

Figura 27: Pessoas se aglomeram para assistir à um baile noturno a céu aberto. Imagem utilizada para corroborar a narrativa da Alfred Döblin.

Assim, podemos inferir que a montagem primou por incluir cenas de um determinado baile noturno de rua ocorrido, ao que tudo indica, em Lisboa, com o objetivo de representar visualmente o relato do refugiado judeu. 
Referentemente às anotações de Antoine de Saint-Exupéry, há uma passagem, a partir dos $32 \mathrm{~min} 14 \mathrm{~s}$, em que o aviador discorre sobre a fragilidade portuguesa perante a sanha destrutiva da guerra. Ele entende que, pelo fato de Portugal não possuir um exército à altura dos das nações beligerantes e, consequentemente, não ter condições de se defender de um eventual ataque, o pequeno país ibérico seria um alvo fácil dentro daquele cenário caótico de ataques nos anos iniciais do conflito mundial.

O autor de $O$ pequeno príncipe passou por Lisboa em dezembro de 1940, mesmo ano em que ocorre a Exposição do Mundo Português. Como o encerramento deste evento se deu no dia dois de dezembro daquele ano, não podemos assegurar que o aviador tenha efetivamente visitado essa feira, entretanto, é certo que ele estava a par dos temas expostos, dentre eles, a exaltação do passado português.

Dessa forma, uma vez que o aviador francês não conseguia entender como o governo português se mantinha alheio diante dos horrores da guerra, ele oferece, de forma anedótica, porém, crítica, uma explicação ao fato de Portugal preferir celebrar o seu passado a se solidarizar com as vítimas da guerra. Pare ele, essas figuras históricas representavam "sentinelas de pedra" que se colocavam como barreiras contra uma possível arremetida estrangeira.

Assim, a fim de corroborar os registros anotados por Saint-Exupéry, a montagem de Fantasia Lusitana faz coincidir suas palavras com cenas do cinejornal de Lopes Ribeiro sobre a Exposição do Mundo Português (Figura 28):

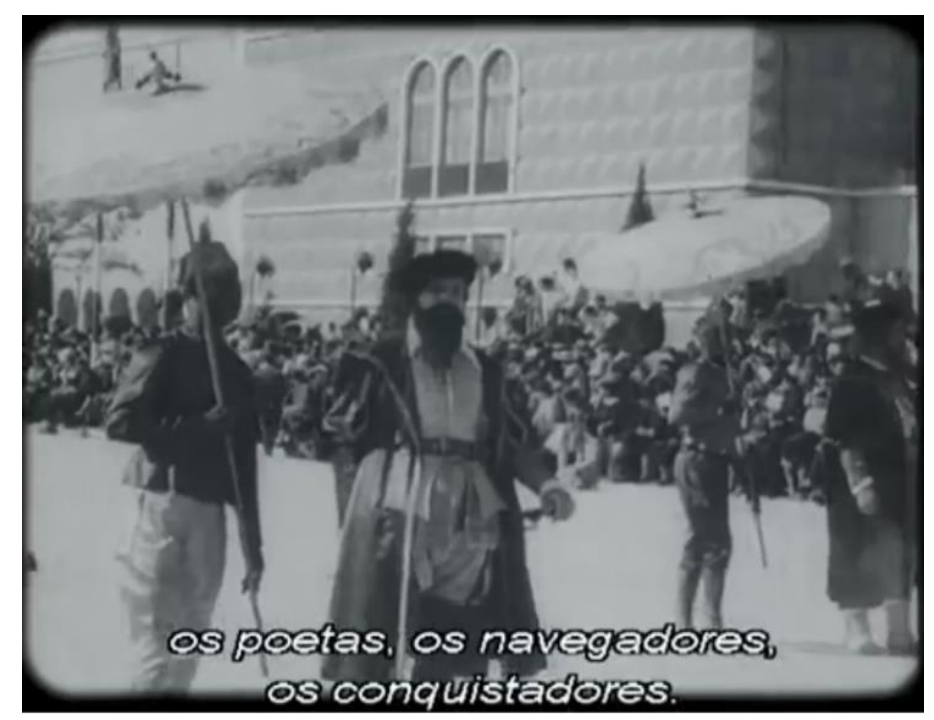

Figura 28: Figurantes vestidos a caráter representam os heróis do passado histórico de Portugal no Cortejo Histórico do Mundo Português. 
A montagem exibe uma cena do Cortejo Histórico do Mundo Português, desfile que fazia parte daquela exposição, na qual vemos pessoas vestidas com indumentárias dos séculos passados, representando "os poetas, os navegadores, os conquistadores", conforme se lê na legenda em língua portuguesa. Eu suma, as palavras de Saint-Exupéry ganham forma quando a montagem do documentário oferece elementos visuais a fim de que o espectador seja levado a ver aquilo que ele deve enxergar, conforme a proposta do documentário.

Por fim, gostaríamos de analisar um excerto referente às anotações de Erika Mann acerca de sua estada por Lisboa e entender como a montagem é construída a fim de corroborar aquilo que é enunciado por ela. Trata-se de uma passagem em que a alemã relata ter ido à um café em uma praça principal de Lisboa e que o local estava "literalmente a transbordar de gente", a partir dos 40min06s. Ela discorre desde a torrefação e o amargor do café ali servido, como também descreve os clientes estrangeiros, desde suas roupas ou condições financeiras, além da ânsia que tinham por obter notícias das terras que tinham deixado, procurando outros refugiados que falavam os mesmos idiomas.

Referente à sincronia entre o testemunho de Mann e as imagens de arquivos recuperadas, o espectador vê um estabelecimento comercial a partir da via pública, em cuja fachada se lê "café restaurante", e pessoas que ali deambulam, captadas pela câmera (Figura 29). Por outro lado, as legendas em português revelam aquilo que foi registrado por Mann em seu diário: "Um pouco antes das cinco entrei no pequeno café da praça principal". A declarante não revela o nome exato do café ou que praça principal seria essa, mas a montagem do documentário oferece as imagens necessárias para que o espectador associe a descrição de Mann com cena disponibilizada. 


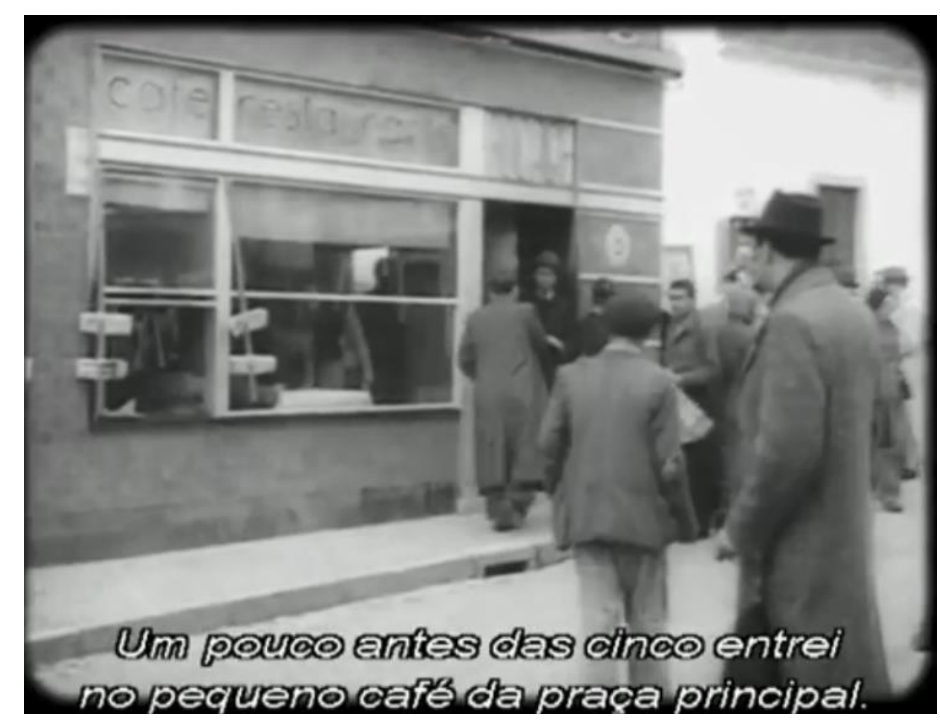

Figura 29: Transeuntes caminham por rua portuguesa em frente a um estabelecimento comercial em cuja fachada se lê "café restaurante".

Em seguida, a atriz alemã informa que o café o qual ela adentrara estava superlotado, ou seja, "literalmente transbordando". E, para que o espectador tenha a dimensão do que aquela cena poderia representar, ocorre a sobreposição do relato oral da testemunha com uma imagem de arquivo recuperada (Figura 30).

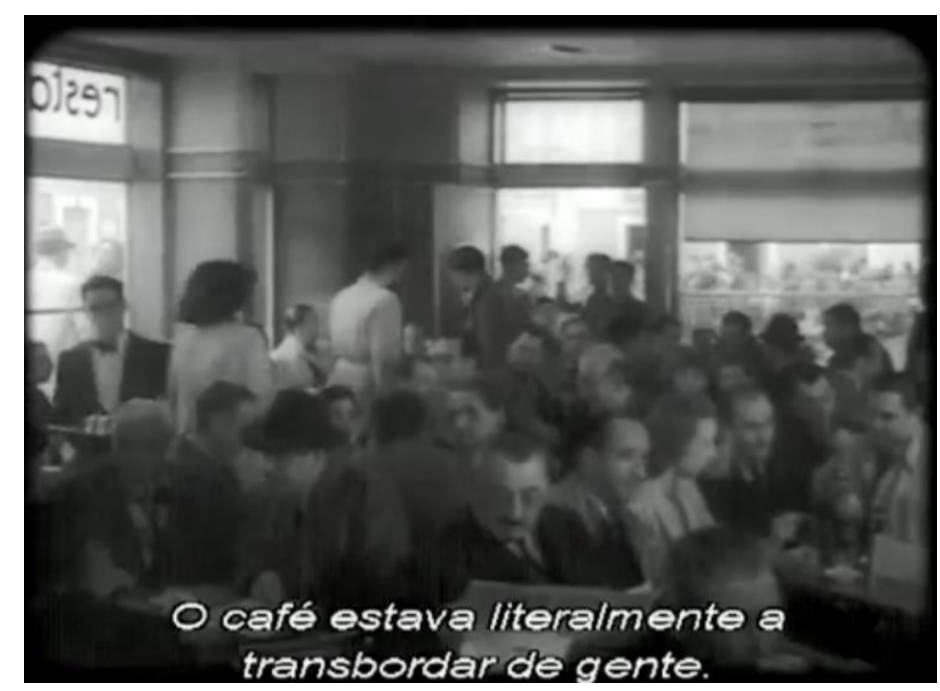

Figura 30: Imagem do interior de um café lotado, representado aquele descrito por Erika Mann.

Nesta cena, vemos a imagem de um restaurante a partir do seu interior, além de dezenas de pessoas que se encontram ao balcão e ao redor das mesas. Elas estão fumando, lendo jornais, e principalmente conversando. Há também pessoas que estão em deslocamento, sendo, uma dela, um garçom. A legenda justaposta à essa imagem indica que "O café estava literalmente a transbordar de gente", servindo como representação verossímil do próprio café o qual Mann teria ido. 
Assim, podemos dizer que os exemplos acima tiveram a intenção de demonstrar de que forma a montagem de Fantasia Lusitana tem um objetivo a cumprir. No caso em questão, ao conjugar os relatos das três testemunhas com cenas recuperadas de material de arquivo, a intenção da montagem é dar suporte à fala desses estrangeiros, fornecendo imagens aproximativas, quiçá semelhantes àquelas referidas em seus relatos. As imagens do baile ou do café, portanto, poderiam ter sido as dos mesmos locais aos quais Döblin e Mann se referiam, e as cenas do Cortejo Histórico representam aqueles heróis do passado mencionados por Saint-Exupéry. Enfim, tais cenas foram introduzidas com a intenção de construir verossimilhança àquilo que é dito pelos estrangeiros.

\subsection{A ridicularização dos discursos de Salazar}

Conforme temos dito, vários trechos de discursos lidos na voz de Salazar foram recuperados e são parte integrante de Fantasia Lusitana. Gostaríamos de analisar de que forma excertos desses discursos são utilizados no documentário, uma vez que eles representam a ideologia do próprio Estado Novo, e, portanto, são desconstruídos pela montagem. Começamos por uma passagem bastante emblemática.

Trata-se de um trecho que exibe cenas dos festejos do oitavo centenário da fundação de Portugal, comemorado em 1940, nas quais o Presidente da República, General Oscar Carmona, passeia por entre a multidão, recebendo uma chuva de pétalas de flores aos 04min13s. Ao mesmo tempo em que essas imagens são exibidas, o espectador ouve a voz off de Salazar lendo um discurso no qual ele descreve a essência dos portugueses:

\footnotetext{
Aquelas qualidades que se revelaram e fixaram e fazem de nós o que somos e não outros; aquela doçura de sentimentos, aquela modéstia, aquele espírito de humanidade, tão raro hoje no mundo; aquela parte de espiritualidade que, malgrado tudo que a combate, inspira ainda a vida portuguesa [...] (FANTASIA LUSITANA, 2010, 4:10 - 4:29, grifo nosso).
}

Ao definir a natureza do povo português, o ditador acaba por listar várias características positivas, porém, idealizadas. A construção dessa imagem está em consonância com as ideias nacionalistas propagadas pelo Estado Novo, sobretudo nesses primeiros anos de consolidação do governo. No entanto, a montagem do documentário proporciona o sincronismo entre a imagem e o som, isto é, ao mesmo tempo em que o espectador vê Carmona beijando um bebê (Figura 31) ele ouve a voz de Salazar enunciando "aquela doçura de sentimentos", referindo-se à alma portuguesa. 
Esta simultaneidade gerada pela montagem ratifica o que é dito pela voz de Salazar, porém, a imagem alude ao "estereótipo do político em campanha”, compartilhada pelo senso comum atual, que, a fim de conquistar votos, anda sorridente por entre o povo, distribui abraços e beija criancinhas, gerando uma imagem caricata e risível do Presidente e, por extensão, do próprio ditador, que dá voz à cena. Além disso, há o contraste entre a imagem viril do militar, com seu uniforme e suas divisas, e o beijo dado em um bebê, fato que remete à ternura e à delicadeza, ou seja, à "doçura de sentimentos". Assim, a edição neste trecho procura ridicularizar tanto a figura de Carmona quanto a de Salazar. Há de se destacar, entretanto, que este efeito é produzido pela montagem de Fantasia Lusitana e diverge daquilo que se almejou à época da exibição desses materiais propagandísticos.

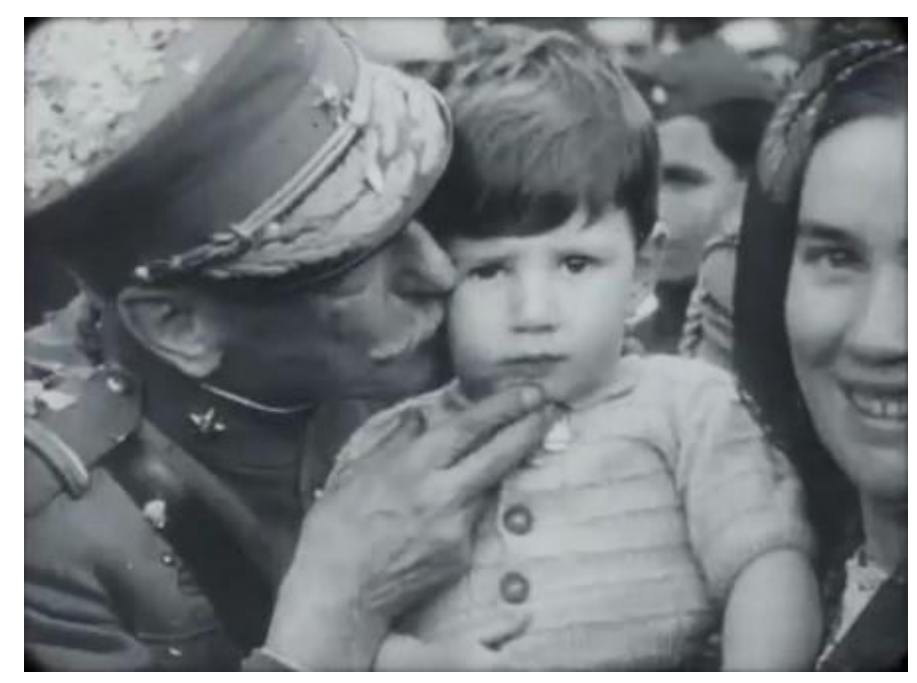

Figura 31: O Presidente da República, General Oscar Carmona beija um bebê durante os festejos do oitavo centenário da fundação de Portugal em 1940.

Outro trecho de discurso político proferido pelo ditador envolve um pedido de bom ânimo aos portugueses, a fim de enfrentar as dificuldades e os problemas. Nele, Salazar brada: "Tenhamos confiança! Tenhamos fé na lealdade própria e alheia, na ordem, no trabalho, na serenidade e seriedade com que havemos de encarar os problemas e acudir às dificuldades" (FANTASIA LUSITANA, 2010, 16:21 - 16:39, grifos nossos). Essas palavras, inseridas no documentário em voz off, são exibidas pela montagem em justaposição a um intertexto onde se lê "A visita oficial da 'HOME FLEET"” (FANTASIA LUSITANA, 2010, 16:24), em cujo fundo há a imagem da bandeira da Marinha Real Britânica (Figura 32). 


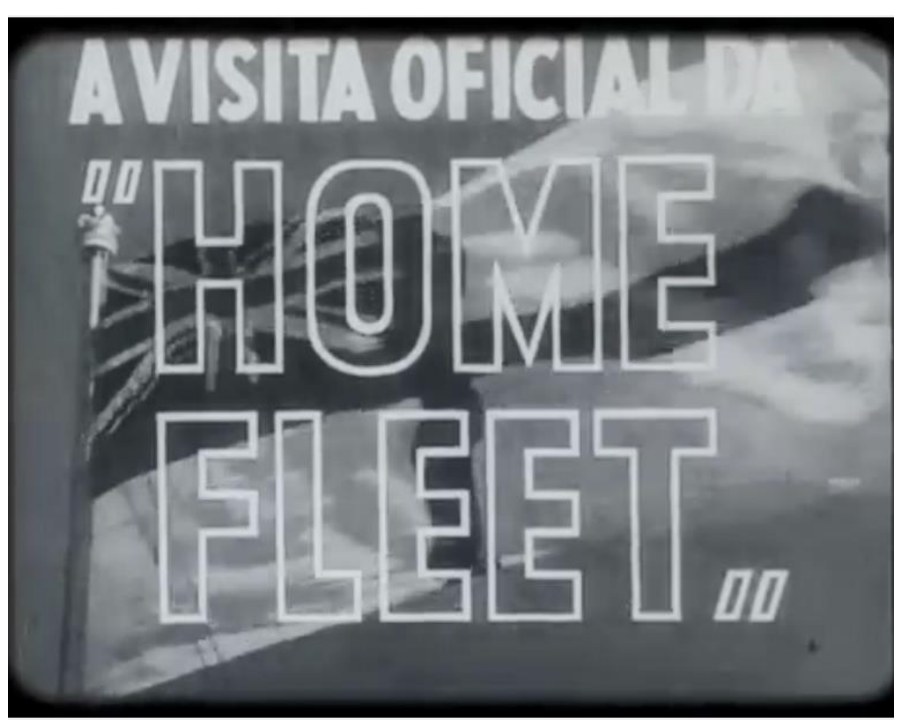

Figura 32: Intertexto que retrata a visita oficial da Home Fleet (Marinha Real Britânica) a Portugal.

É pertinente lembrar que já analisamos nesta dissertação a presença militar em Portugal de países beligerantes inimigos, graças ao status de neutralidade português. No entanto, gostaríamos de focar agora um aspecto específico, isto é, a aliança secular entre Portugal e a Grã-Bretanha. A montagem faz com que Salazar conclame "fé na lealdade própria e alheia" ao mesmo tempo em que exibe a bandeira da Marinha Real Britânica, isto é, da "Home Fleet". Este procedimento evoca o antigo pacto entre as duas nações.

Ao esclarecer como se dava a política externa portuguesa "desde os fins da Monarquia ao Estado Novo, até o fim da II Guerra Mundial” (ROSAS, 1995, p. 25), Fernando Rosas recorda a antiga aliança bilateral, lembrando uma das características daquele governo, que possuía

[...] uma espécie de permanente drama de consciência: ter simultaneamente de desconfiar dos repetidos manejos britânicos contra as colônias portuguesas [...] e de se agarrar à "Velha Aliança" como garantia básica da sua protecção; de ser antibritânico por vocação e pró-britânico por realismo (ROSAS, 1995, p. 25).

O trecho acima evidencia a posição subalterna de Portugal perante à potência britânica. Incapaz de defender a si mesmo, o pequeno país lusitano não apenas contava com a proteção do Reino Unido, mas também desconfiava de seu aliado, o que o colocava numa situação de fragilidade. Analisamos anteriormente a vulnerabilidade de Portugal acerca da ameaça à soberania portuguesa nos Açores.

Salazar continua seu discurso convidando o povo português a confiar no Estado: "Confiemos sobretudo, mais que na força das armas, na coesa e firme unidade nacional [...]" (FANTASIA LUSITANA, 2010, 16:40 - 16:47). Neste trecho, as imagens exibidas 
são, efetivamente, as da visita oficial da Marinha Britânica a Portugal, numa sequência que apresenta opulentos navios de guerra, com destaque para seus portentosos e destrutivos canhões.

Ao mesmo tempo em que a presença da marinha britânica serve como proteção para Portugal, ela se apresenta como ameaça, recordando a dubiedade descrita por Rosas (2001). A montagem faz coincidir a fala acima de Salazar, especificamente o trecho em que ele enuncia a "força das armas", com uma imagem de canhões obtida a partir de um navio de guerra da frota inglesa, sendo que ao fundo, no horizonte, o espectador vê a cidade de Lisboa (Figura 33).

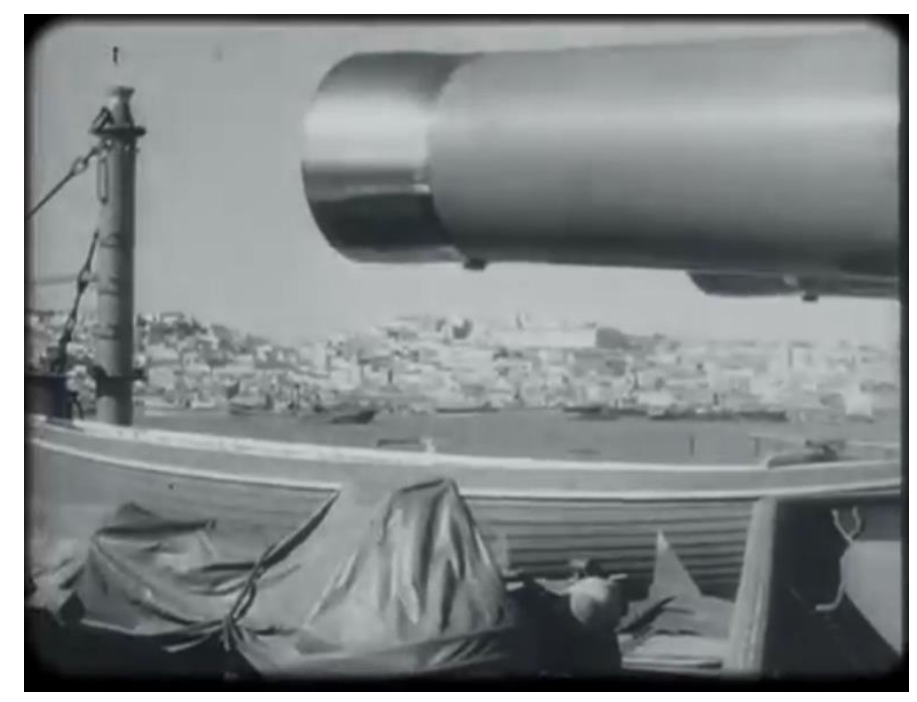

Figura 33: Destaque para os canhões de um dos navios da Home Fleet com imagens de Lisboa ao fundo.

A ironia por trás da montagem consiste do fato de o ditador concitar os portugueses a confiar "mais na unidade nacional do que na força das armas", porém, quando o espectador ouve a expressão "forças das armas" ele vê a imagem de canhões britânicos, lembrando que, a qualquer momento, eles podem disparar contra Lisboa. Embora Salazar peça ao povo para "confiar na unidade nacional” a despeito da "força das armas", a imagem mostra exatamente o contrário, ou seja, mostra que as armas inglesas têm maior poder do que o discurso de Salazar, escarnecendo, portanto, o ditador.

Por fim, gostaríamos de evidenciar mais uma passagem em que o discurso do Chefe da Nação acaba sendo ridicularizado pela montagem. Trata-se da recuperação de cenas da visita dos falangistas espanhóis a Lisboa. Neste evento, que também contou com a presença da Mocidade Portuguesa e das juventudes alemãs e italianas, vemos cenas de chefes militares devidamente paramentados, desfiles com homens e mulheres a saudar, 
jovens que se ajoelham em apenas uma das pernas, em sinal de respeito, pessoas que fazem a saudação romana e há também quem faça o sinal da cruz.

Neste pequeno trecho percebemos a disciplina militar e religiosa acontecendo no mesmo tempo e espaço - a locução inerente ao material informa se tratar de uma "missa campal dos falangistas da Galiza e dos flechas de Badajoz e de Cáceres" (FANTASIA LUSITANA, 2010, 18:29 - 18:34). Subitamente, a voz avultada de Salazar invade as cenas e cobre a locução original, quando então, passamos a ouvir: "Temos passado anos a pregar pela palavra e pelo exemplo, insistentemente, teimosamente, que todos, não somos demais para continuar Portugal” (FANTASIA LUSITANA, 2010, 18:46 - 19:00). Ao mesmo tempo em que o espectador ouve Salazar mencionar os "anos a pregar pela palavra e pelo exemplo" ele vê as imagens do sacerdote que celebra a referida missa campal, rodeado por meninos daquelas juventudes (Figura 34).

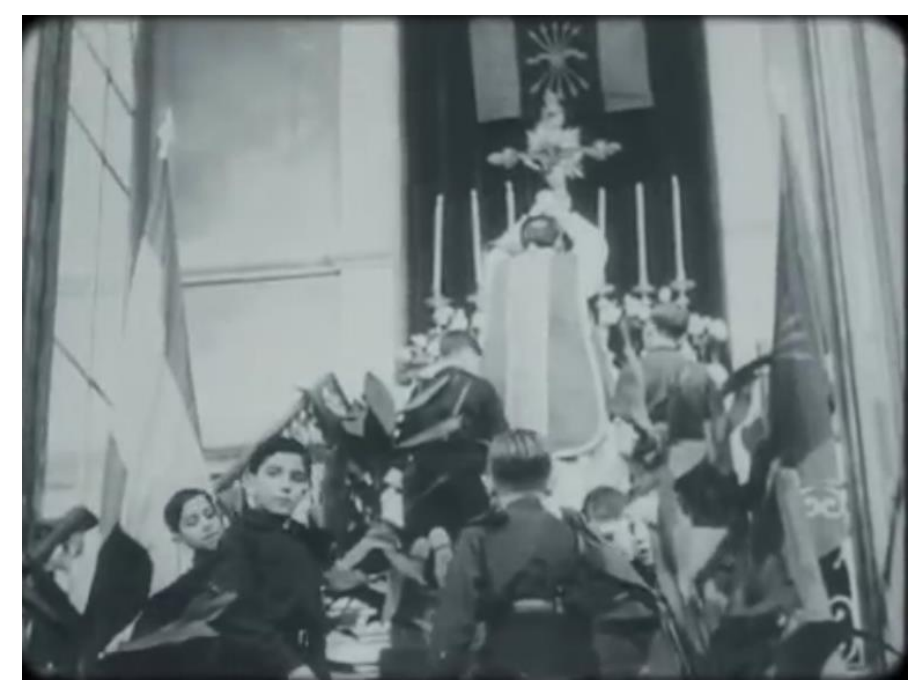

Figura 34: Missa campal realizada em Lisboa pela ocasião da visita dos falangistas espanhóis, com a presença da Mocidade Portuguesa e das juventudes alemãs e italianas.

A montagem de Fantasia Lusitana consegue unir a imagem do religioso com a voz de Salazar a dizer que Portugal tem "pregado pela palavra e pelo exemplo". Como se sabe, o verbo "pregar” está dentro da esfera semântica da religião e está vinculado à ideia de catequizar ou doutrinar alguém de acordo com seus dogmas. Esta coincidência entre som e imagem não apenas remete aos séculos de expansão do império, quando Portugal combatia "pela cruz e pela espada", como também recorda o mito da essência católica da identidade nacional, quando analisamos os mitos ideológicos fundadores do Estado Novo, de Fernando Rosas (2001). 
Por fim, assim que Salazar afirma que "todos, não somos demais para continuar Portugal", o espectador vê uma bandeira ser desfraldada e ocupar aproximadamente setenta por cento da tela. Nela, lemos o nome "Portugal" dentro de uma faixa, e logo abaixo a figura da águia nazista, com a cruz suástica em seu peito (Figura 35). A meticulosa montagem faz com que a enunciação da palavra "Portugal", que havia acabado de ser pronunciada na voz de Salazar, se associe à imagem da mesma palavra, agora estampada na bandeira, formando um contínuo.

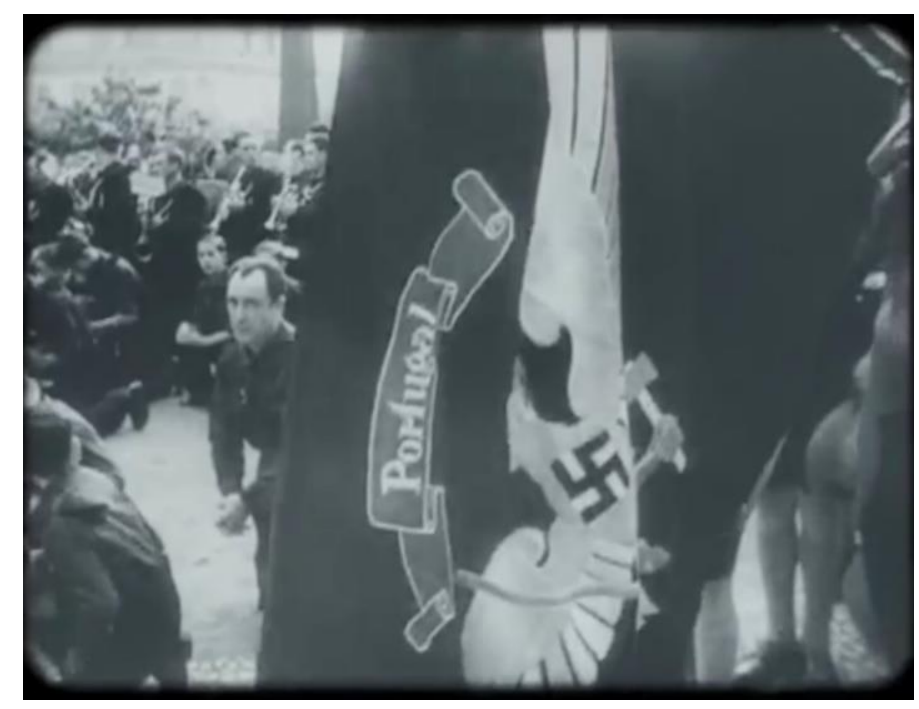

Figura 35: Bandeira que reúne o nome "Portugal" com o símbolo nazista da águia com a suástica.

É necessário lembrar que, embora o discurso e as imagens tenham sido registrados na década de quarenta do século passado, o documentário foi lançado em 2010, já durante o século XXI. Há, portanto, dois aspectos presentes neste trecho da montagem que gostaríamos de abordar a partir de agora.

O primeiro está ligado à ironia gerada entre as palavras de Salazar e a exibição da bandeira com a suástica. Em seu discurso, o ditador se dirige ao povo português e fala sobre a continuidade de Portugal, diz que "todos não somos demais", ou seja, é necessário contar com o apoio e com a integração de todos os concidadãos para que o país continue com a sua "missão" de "pregar pela palavra e pelo exemplo". O discurso enaltece o legado português e conclama a união entre os compatriotas. Porém, a ironia se concretiza quando a montagem exibe a referida bandeira, pois vemos "Portugal" compartilhando a mesma insígnia com a águia nazista, numa espécie de aliança, ou seja, embora o ditador instigue os portugueses a se unirem, já existe uma união ideológica entre os governos de Portugal e da Alemanha, mas não só, lembrando que representantes dos quatro governos ditatoriais 
de extrema direita (Alemanha, Itália, Espanha e Portugal) se encontravam em Lisboa para aquele evento.

Em outras palavras, ainda que o governo português quisesse fazer crer à sua população que a união e o apoio do povo pudessem dar continuidade ao país, fica patente a dependência que Portugal tinha em relação às outras nações europeias, seja a GrãBretanha, conforme vimos na passagem da Home Fleet por Lisboa, sejam os governos autoritários nazistas e fascistas que partilhavam de ideias semelhantes.

O segundo aspecto que gostaríamos de analisar se refere à distância temporal que se dá entre o presente diegético do documentário, ou seja, o período da Segunda Guerra Mundial, e o período referente ao momento em que o público passou a ter acesso à película, isto é, a partir de seu lançamento em 2010. Este distanciamento de quase setenta anos foi necessário para que o espectador formasse opinião acerca de Hitler e do nazismo, elementos indissociáveis do holocausto judeu e dos campos de concentração e extermínio.

Por mais que a cena seja solene, mostrando, ao fundo, jovens se ajoelhando em respeito à figura do estado e da religião, a bandeira que se sobressai na tela agrega os governos de Portugal e da Alemanha num mesmo estandarte, ou seja, revela o entendimento existente entre eles e associa o país ibérico ao nazismo.

Recuperar esta imagem dos arquivos e apresentá-la no presente juntamente com a voz de Salazar pode ser visto como uma forma de denunciar as políticas do Estado Novo português de então. Revelar a união desses dois governos em uma só bandeira tem o intuito de recordar que Salazar também criou instrumentos de perseguição contra quem contestasse o seu governo, tais como a polícia política (PVDE/PIDE), que utilizava tortura contra seus inimigos. É lembrar que ele criou a colônia penal do Tarrafal (Cabo Verde) em 1936 - e que viria a se converter em um campo de concentração contra presos políticos. Assim, a desconstrução da imagem de Salazar ao aproximá-lo da figura da Alemanha nazista só é possível através do distanciamento temporal entre o presente diegético (período da guerra) e o lançamento do documentário (2010), espaçamento necessário para que ocorra essa ironia. 


\subsection{As fotografias utilizadas em Fantasia Lusitana}

Dentre o material de arquivo empregado na composição do documentário de João Canijo, destacamos a presença de fotografias. Elas foram extraídas de várias fontes, desde retratos que foram revelados para registrar o cotidiano, até imagens empregadas em jornais e revistas, bem como aquelas utilizadas em documentos de identificação. Uma vez que esses registros fotográficos foram capturados pela lente da câmera de filmagem, passaram a integrar a película e se tornaram material fílmico. Porém, para efeitos de análise, iremos refletir a respeito da fotografia e de seu emprego em Fantasia Lusitana.

Acerca da fotografia, Walter Benjamin (1996) declara que

A natureza que fala à câmera não é a mesma que fala ao olhar; é outra, especialmente porque substitui a um espaço trabalhado conscientemente pelo homem, um espaço que ele percorre inconscientemente. [...] Só a fotografia revela esse inconsciente ótico, como só a psicanálise revela o inconsciente pulsional (BENJAMIN, 1996, p. 94).

Para o ensaísta alemão, a fotografia tem o poder de revelar o inconsciente, ou seja, uma imagem fotográfica é passível de apresentar caracteres que não seriam observados simplesmente se o objeto retratado não estivesse em frente à uma câmera. Isso ocorre porque um determinado modelo tem a sua imagem preservada naquele átimo de segundo em que a câmera a registrou, permitindo, assim, que o observador deseje inquirir a respeito do objeto observado, "algo que não pode ser silenciado, que reclama com insistência o nome [...], que também na foto é real, e que não quer extinguir-se na 'arte"” (BENJAMIN, 1996, p. 93).

De acordo com Susan Sontag (2004),

Fotos fornecem um testemunho. Algo de que ouvimos falar mas de que duvidamos parece comprovado quando nos mostram uma foto. Numa das versões da sua utilidade, o registro da câmera incrimina [...]. Numa outra versão de sua utilidade, o registro da câmera justifica. Uma foto equivale a uma prova incontestável de que determinada coisa aconteceu. A foto pode distorcer; mas sempre existe o pressuposto de que algo existe, ou existiu, e era semelhante ao que está na imagem (SONTAG, 2004, p. 9).

Para a intelectual, as fotografias funcionam como peças testemunhais de acontecimentos, ou seja, elementos comprobatórios que podem incriminar ou justificar. Por mais tendenciosa que seja, uma foto carrega o pressuposto de que algo efetivamente ocorreu, fazendo com que a imagem reproduzida adquira status de evidência.

Dessa forma, com base nos apontamentos de Benjamin (1996) e de Sontag (2004), podemos dizer que um dos empregos das fotografias no documentário é respaldar a fala 
dos intelectuais estrangeiros. A montagem, ao utilizar retratos de refugiados, faz com que o espectador tenha interesse por aquelas pessoas, fazendo despertar o desejo de conhecer seus nomes, idades, nacionalidades, origens e destinos. Em outras palavras, aquela fração de segundo registrada e imortalizada pela lente da câmera inquieta o observador, fazendo com que algo seja desperto em seu inconsciente, como afirma Benjamin (1996).

Por outro lado, como explica Sontag (2004), essas fotos também servem como provas irrefutáveis de um acontecimento histórico, isto é, estrangeiros se refugiaram em Portugal durante os anos de guerra, passando por provações e aguardando pelos navios que lhes tirariam da Europa. Para já, gostaríamos de analisar o emprego de algumas dessas imagens pela montagem de Fantasia Lusitana e o papel que elas representam na construção do argumento do filme.

Na passagem em que Alfred Döblin confessa estar vivenciando um sentimento de derrota (FANTASIA LUSITANA, 2010, 19:51) após ter sido surpreendido com a guerra, o que o leva a fugir para Portugal, o romancista começa a descrever suas primeiras impressões sobre Lisboa. As comparações entre o ambiente em que ele estava inserido anteriormente e aquele para o qual tinha se dirigido às pressas são inevitáveis: ele afirma ser "inacreditável" constatar que a capital portuguesa vivia normalmente, com os meios de transporte a funcionar, com os ruídos característicos de uma grande cidade e com o clima festivo devido a um baile que acontecia próximo ao hotel onde se hospedava.

Admitir e reconhecer essas duas realidades concomitantes, a da guerra e a da normalidade, o deixa perplexo a ponto de ele dizer: "Nunca esqueceremos o impacto que isto teve em nós" (FANTASIA LUSITANA, 2010, 20:57). A fim de reforçar tamanho estranhamento, a montagem insere uma fotografia onde aparecem dois meninos com os olhos arregalados, sendo que o mais novo está boquiaberto e segura firmemente a alça da bolsa de uma mulher, possivelmente sua mãe, revelando claramente uma expressão de espanto (Figura 36). Ao mesmo tempo em que fotografia é exibida, ouvimos a voz em alemão e lemos a legenda em português que exclama: "Que mundo. Que mundo!", conciliando a admiração presente no áudio e na imagem. 


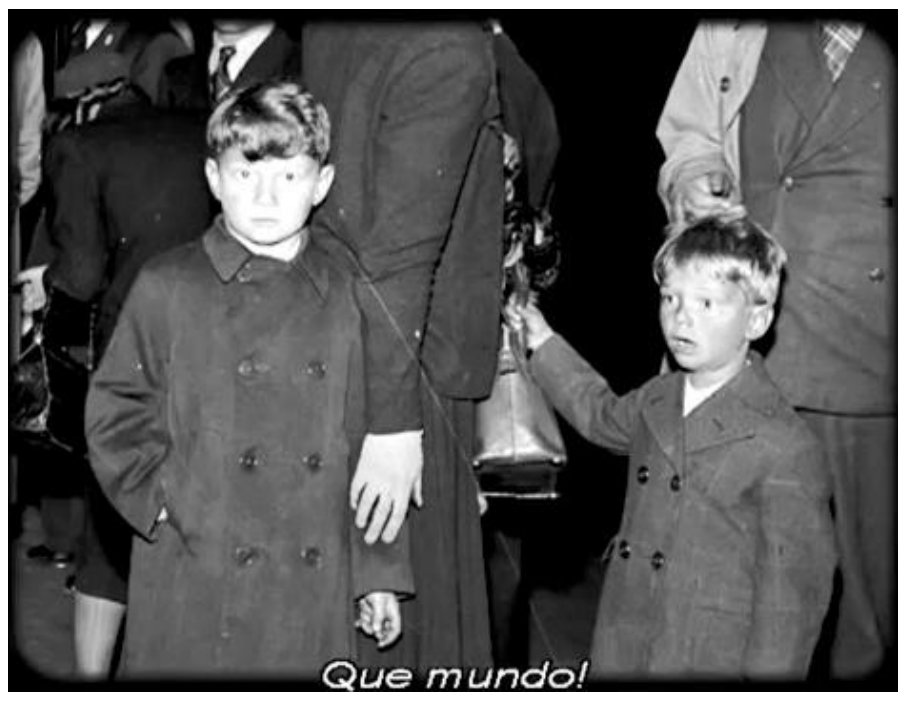

Figura 36: Detalhe de fotografia usada em Fantasia Lusitana em cuja legenda se lê "Que mundo!" ao mesmo tempo em que se vê meninos com os rostos espantados.

Em seguida, outra fotografia é exibida e o espectador percebe que a imagem anterior nada mais era do que um detalhe, ou seja, um recorte da atual. Ela se apresenta em sua totalidade, em plano geral, revelando aquelas crianças no canto inferior direito da tela. Trata-se de um grupo de pessoas com seus filhos, suas bagagens, um carrinho de bebê, provavelmente em uma estação de trem ou um local de desembarque, dado que há homens que parecem estar vestindo uniformes de carregadores de estação (Figura 37). Este contexto leva a crer que aquela gente, assim como Döblin, fugia da guerra.

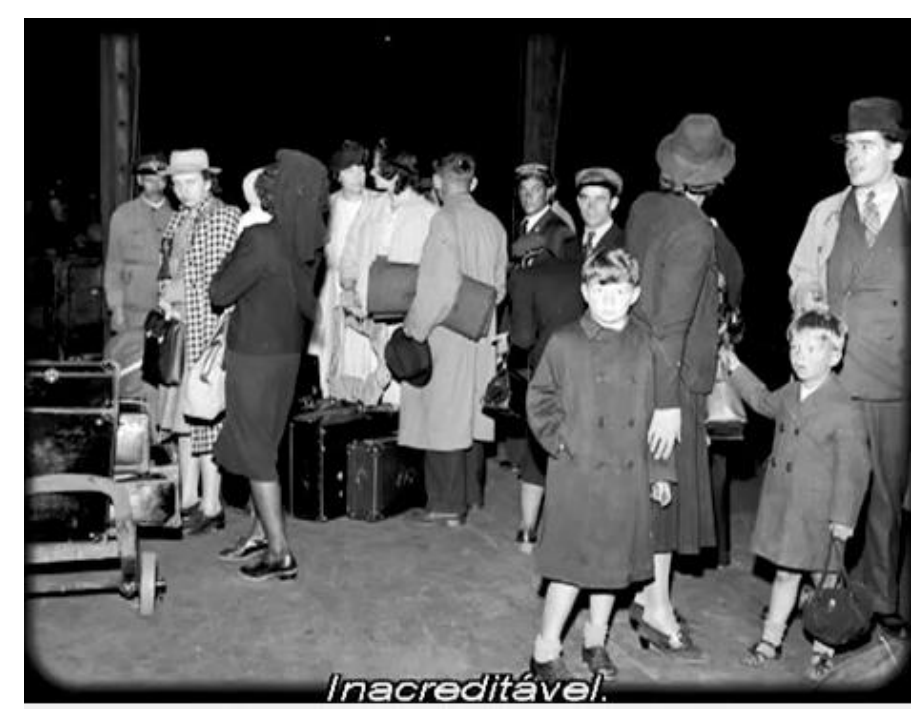

Figura 37: Fotografia em sua totalidade utilizada em Fantasia Lusitana em cuja legenda se lê "Inacreditável".

Ao mesmo tempo em que esta fotografia é apresentada, o espectador ouve as anotações de Döblin e lê a legenda em português que diz: "Inacreditável” (FANTASIA LUSITANA, 2010, 20:53). Esta palavra parece representar não apenas o sentimento do 
escritor alemão, mas também o daquele grupo de pessoas que está chegando a uma terra desconhecida, mais uma vez, revelando a associação de ideias gerada pela montagem.

Entretanto, destacamos que a estratégia adotada pela montagem de inicialmente aproximar o rosto espantado das crianças para, em seguida, revelar o local onde aquela imagem fora tirada, serviu para a construção da significação. Em suma, a edição das imagens fotográficas acaba por direcionar a visão do espectador: primeiramente o assombro nos olhares infantis e depois a complexidade vivida por aqueles expatriados.

Ainda sobre fotografias, gostaríamos de abordar uma passagem relatada por Erika Mann. Como uma boa correspondente de guerra, a alemã descreve os refugiados que se encontravam em Lisboa física e emocionalmente, enquanto imagens equivalentes são exibidas na tela, contribuindo com a construção de significado. Em um determinado momento, Mann afirma que "É visível a tristeza de todos e a pobreza da sua indumentária. Paira no ar um ambiente de angústia, e de extremo nervosismo" (FANTASIA LUSITANA, 2010, 38:19-38:35).

À medida que as anotações da refugiada vão sendo reveladas, uma sequência de fotografias retrata pessoas com os semblantes angustiados, em consonância com o que é dito. Ao ouvirmos a expressão "extremo nervosismo", aparece a fotografia de uma mulher que fita algo com a cabeça levemente levantada; à sua esquerda há uma criança que também fixa o olhar alhures; à sua direita há outra criança que olha para a câmera fotográfica com uma expressão aflita. Ela cobre a boca com os dedos de sua mão direita, o que intensifica a sensação de inquietação (Figura 38).

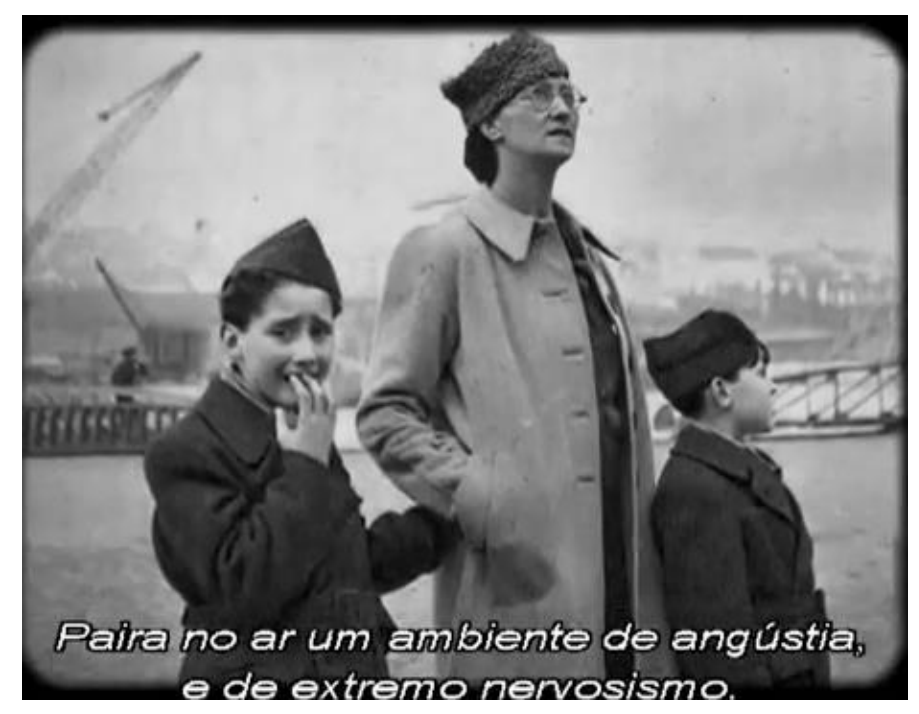

Figura 38: Fotograma de Fantasia Lusitana cuja montagem faz coincidir a imagem exibida com o áudio em alemão (legendado). 
Esta estratégia de montagem reforça aquilo que Mann narra, pois fornece material visual para as palavras conforme vão sendo descerradas. Entretanto, há nesta sequência algo de inusitado, pois, mesmo depois que a voz narrativa emudece e as legendas deixam de ser exibidas, há um silêncio de aproximadamente cinco segundos, porém, com imagens correlatas, traduzindo a condição daqueles refugiados. Destacamos a última fotografia desta sequência, isto é, a imagem de uma mulher cabisbaixa que cobre os olhos com a mão esquerda, como alguém que deseja esconder o pranto (Figura 39), denotando desolação e desespero, ou seja, legitimando a narrativa de Erika Mann, intensificada pelo silêncio.

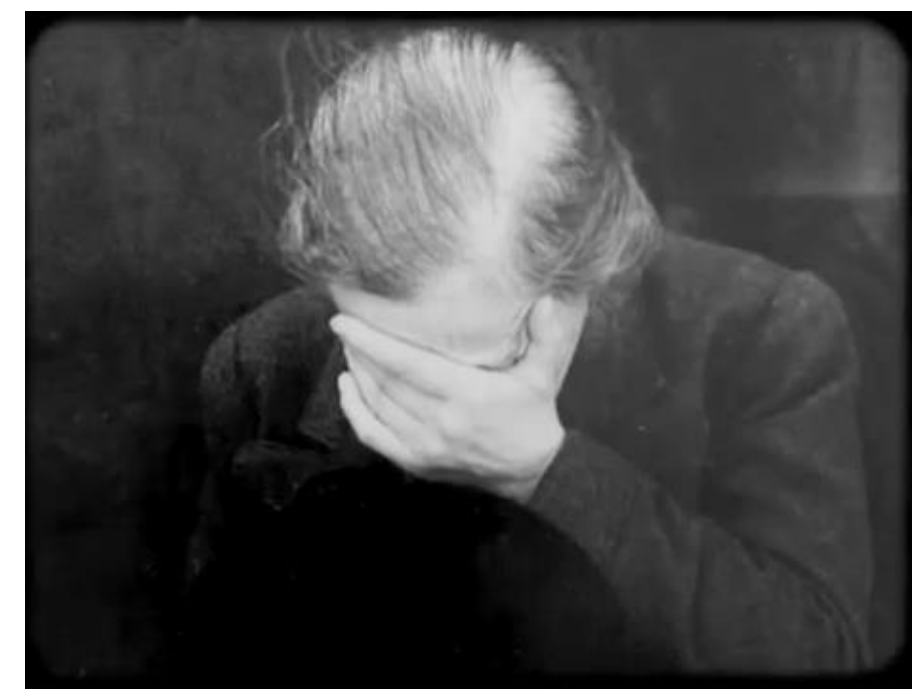

Figura 39: Mulher cobre os olhos em desespero. Imagem utilizada pela montagem de Fantasia Lusitana para gerar significado.

A tônica das anotações de Erika Mann versa sobre os refugiados estrangeiros em Portugal. Ela tem um olhar compassivo para com eles, pois, ela mesma se encontra em situação análoga. As ruas estavam abarrotadas de pessoas que perambulavam sem destino, e a intelectual destaca a angústia e o desespero que tomavam conta dessa gente, uma vez que a única coisa lhes restava fazer era esperar. Em uma sequência que começa aos 23 min57s, diversas imagens desses refugiados são exibidas a fim de respaldar suas palavras.

Em determinado momento, a primogênita de Thomas Mann afirma que "os refugiados andavam sem sentido pelas ruas" (FANTASIA LUSITANA, 2010, 24:21) quando, subitamente, o espectador vê a fotografia de uma mulher que, pelo biotipo, não parece ser portuguesa. Ela veste roupas escuras, carrega uma sombrinha preta e está a mostrar um papel para um homem. Tem-se a impressão de que ela escreve algo no papel, 
pois há um objeto que se assemelha a uma caneta. O senhor observa atentamente o que está sendo escrito, denotando o esforço empregado por ambas as partes por se comunicar (Figura 40). O registro deste flagrante é habilmente utilizado pela montagem para fornecer uma imagem visual daquilo que Mann está relatando, principalmente ao gerar sincronicidade entre as palavras da intelectual, reveladas pela legenda em língua portuguesa, e a fotografia em si.

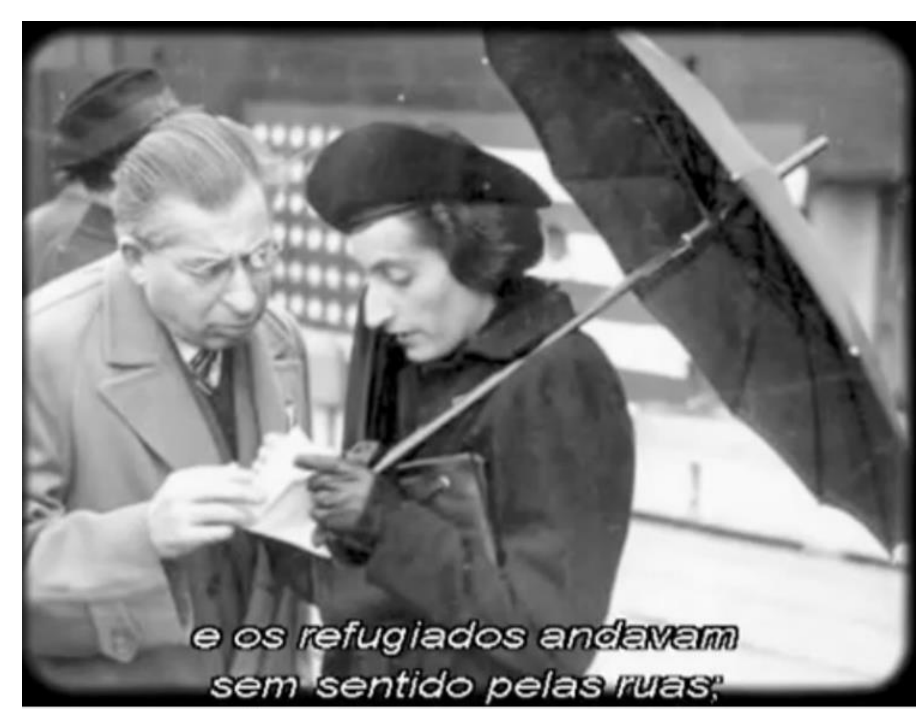

Figura 40: Sincronia entre a fotografia de uma estrangeira que tenta se comunicar com um português e a legenda com a fala de Erika Mann: "e os refugiados andavam sem sentido pelas ruas": coincidência gerada pela montagem.

Dessa forma, a utilização de fotografias acaba por consubstanciar a fala dos três intelectuais que deixaram registros referentes às suas passagens por Lisboa. A pesquisadora Susana Guerra faz uma síntese a respeito da natureza dessas imagens em Fantasia Lusitana:

Vemos fotografias de homens e mulheres, sozinhos ou em grupos, congelados numa espera indefinida, em filas para obter notícias, correspondência, alimentos. Muitas das fotografias mostram pessoas sentadas ao lado de malas e embrulhos, amontoados na rua ou na gare de estações de trem. Rostos apáticos preenchem os planos. Olham algo distante, manifestam cansaço, revelam uma vida interrompida (GUERRA, 2015, p. 98).

A maioria desses retratos reúne elementos que traduzem determinados aspectos, tais como:

- Expectativa e incerteza (espera indefinida; filas para obter notícias, correspondência e alimento);

- Transitoriedade (malas e embrulhos; pessoas na rua ou na gare de estações de trem); 
- Ruptura brusca (rostos apáticos, olhar distante, cansaço, vida interrompida).

Em suma, apesar de estarem a salvo em Portugal, esses refugiados sentem-se angustiados e ligados ao mundo que lhes fora roubado (Figura 41).

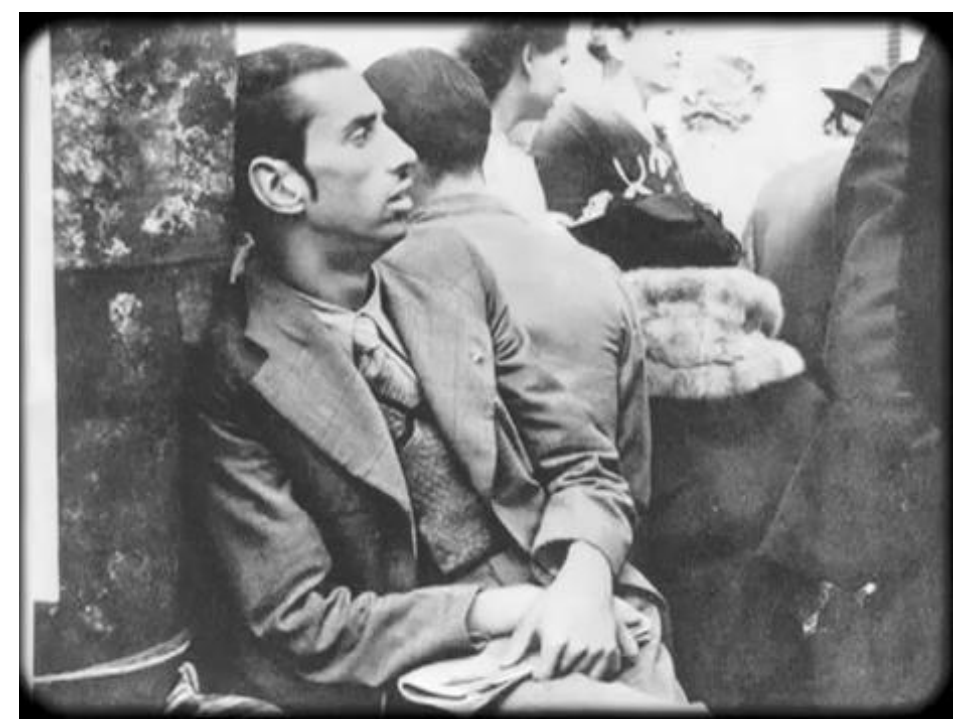

Figura 41: Grupo de refugiados com destaque para a figura de um homem com a expressão cansada, sentado, segurando um jornal. Esta imagem ajuda a construir a narrativa de Erika Mann.

É pertinente recordar que a perspectiva desses estrangeiros se opõe fortemente à construção feita pela propaganda salazarista de um Portugal pacífico, ordeiro, com motivos sobejos para comemorar, ou seja, o chamado "oásis de paz numa Europa em guerra".

\subsubsection{O olhar por trás das fotografias de rostos}

Dentre as inúmeras fotografias recuperadas em Fantasia Lusitana devemos considerar aquelas utilizadas em documentos de identificação. Ao abordar o momento histórico da Segunda Guerra Mundial, é sabido que milhares de estrangeiros transitaram por Portugal para escapar da perseguição nazista, dada a sua condição de neutralidade. Porém, para conseguirem entrar no país, essas pessoas tiveram que se dirigir até os consulados portugueses e solicitar vistos de entrada.

O emprego de fotografias em documentos de identificação é abordado por Susan Sontag (2004). A intelectual explica que

A industrialização da fotografia permitiu sua rápida absorção pelos meios racionais - ou seja, burocráticos — de gerir a sociedade [...]. As fotos foram arroladas a serviço de importantes instituições de controle, em especial a família e a polícia, como objetos simbólicos e como fontes de informação. 
Assim, na catalogação burocrática do mundo, muitos documentos importantes não são válidos a menos que tenham, colada a eles, uma foto comprobatória do rosto do cidadão (SONTAG, 2004, p. 22).

Dessa forma, o retrato fotográfico do rosto passa a ser parte integrante da composição de certos documentos oficiais, funcionando como elemento inconteste de que determinado registro, juntamente com a assinatura do portador, pertence a tal ou qual pessoa. Além disso, Sontag (2004) também menciona a questão do uso de fotografias pelos órgãos de poder e controle como a polícia, em cuja ficha de um criminoso, como se sabe, há um campo específico e obrigatório reservado para a inserção de seu retrato.

Uma vez considerado este aspecto, lembramos que o documentário de Canijo exibe uma sequência com diversas fotografias de rostos de estrangeiros em formulários de pedidos de vistos de entrada em Portugal (FANTASIA LUSITANA, 2010, 45:43 46:16). Em muitos casos, esses pedidos englobam mais de uma pessoa, revelando fotografias de casais ou de um adulto com seus filhos (Figura 42). Ao ver essas imagens, o espectador acaba por sentir empatia por aquelas pessoas, pois reconhece que elas estavam sob a ameaça nazista e a rota de fuga por Portugal se revelava como uma esperança de salvação.

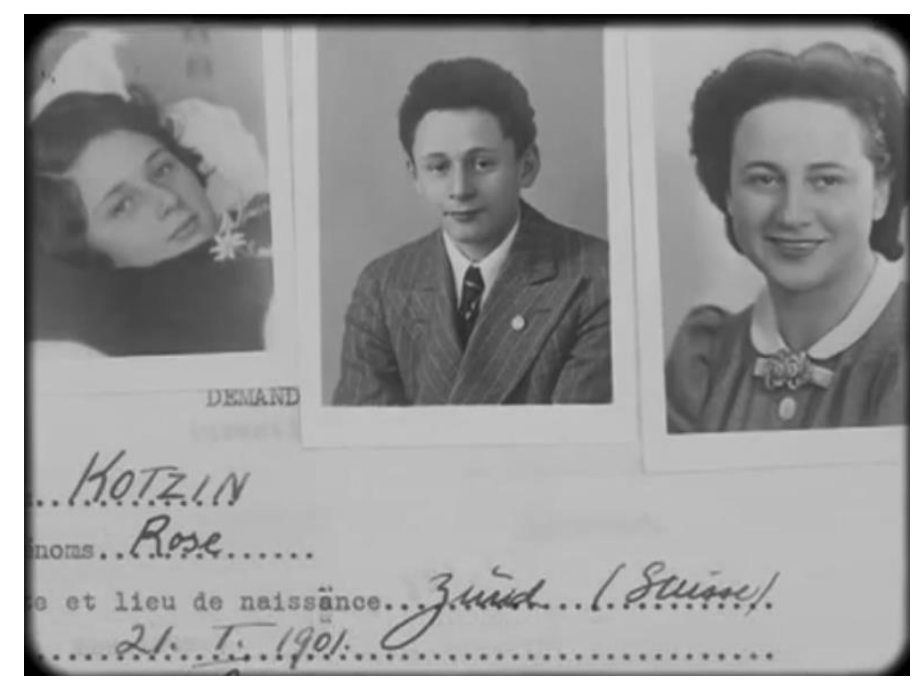

Figura 42: Formulário de pedido de visto para Portugal da família Kotzin, com destaque para a fotografia de, presumivelmente, um casal de filhos jovens e sua mãe.

O momento em que o olhar do espectador se depara com o olhar de um estrangeiro naqueles poucos segundos em que suas imagens são exibidas é efêmero, mas o bastante para criar empatia. Sabe-se que optar pela fuga por Portugal seria uma das opções mais sensatas, pois, caso não tomassem nenhuma ação, aquelas pessoas poderiam ser capturadas e levadas para campos de concentração e extermínio. Conhecer esse contexto 
faz com que seja gerado não apenas um sentimento de piedade por aqueles estrangeiros, mas também um desejo de que eles tenham conseguido ser bem-sucedidos em seus intentos. Este efeito é intensificado pela narrativa de Erika Mann acerca dos estrangeiros que ela observou em Lisboa:

A maioria nem percebia como aqui viera parar e por que motivo teve de fugir.
Mas toda esta gente - belgas, dinamarqueses, noruegueses, homens, mulheres
e crianças - foram surpreendidos nos seus países de origem pelo inimigo como
se é atingido por um terramoto ou um dilúvio (FANTASIA LUSITANA, 2010,
45:56 - 46:19).

A testemunha chama os nazistas de "inimigo" e informa que aqueles refugiados que se encontravam em Lisboa tiveram suas vidas modificadas de forma inesperada, como vítimas de um desastre natural. Assim, podemos dizer que a simultaneidade entre os relatos de Mann e as fotografias dos requerentes de vistos portugueses proporcionada pela montagem gera um sentimento de identificação com aqueles perseguidos.

Este sentimento faz com que nasça no espectador um interesse pelo destino daquela gente, cujas faces são exibidas na tela. Por serem fotografias de documentos consulares, sabemos não se tratar de personagens, mas de pessoas reais, em cujas fichas aparecem seus nomes, suas datas de nascimento e nacionalidades, porém, o que efetivamente faz com que haja identificação e empatia por aqueles estrangeiros é a projeção de seus rostos, de seus olhares. A esse respeito, Xavier (2003) explica que

No cinema, posso ver tudo de perto, e bem visto, ampliado na tela, de modo a
surpreender detalhes no fluxo dos acontecimentos e dos gestos. A imagem na
tela tem a sua duração; ela persiste, pulsa, reserva surpresas [...]. Quando a
imagem é de rostos, tenho a interação dos olhares que se confrontam,
verdadeira orquestração: o olho que vê e o que é visto têm ambos sua dinâmica
própria e cada um de nós já teve a ocasião de avaliar, com maior ou menor
consciência, a intensidade dos efeitos extraídos dessa orquestração (XAVIER,
2003, p. 36).

O intelectual aborda a questão dos olhares que se entrecruzam, isto é, o olhar de quem assiste e o olhar de quem é assistido. Este efeito, gerado pela montagem, faz com que o espectador se interesse pelo destino daquelas pessoas e venha a fazer algumas indagações:

- “Será que seus vistos foram negados ou aprovados?";

- “Será que conseguiram chegar a Portugal com segurança?";

- “Como reconstruíram suas vidas em um novo continente?”;

- “Mudaram de profissão ou mantiveram a que já tinham?"; 
- "Como foi a adaptação em uma nova cultura e um novo idioma?";

- "Retornaram para seus países de origem com o fim da guerra?".

Embora sejam apenas conjecturas, tais indagações poder ser suscitadas naqueles que assistem ao documentário pela essência humana presente por trás daquelas fotografias de rostos. Vejamos um exemplo:

Aos 45min58s (Figura 43) é exibido o "Pedido de visto em passaporte" da alemã Hildegard Donath, nascida em Dresden, aos 26 de julho (a fotografia da solicitante cobre o ano de nascimento). Este pedido foi feito ao Consulado de Portugal em Madrid. Pouco sabemos a respeito desta jovem, apenas que ela era solteira e exercia a profissão de secretária. Também é possível ler o nome "Palace Hotel", local onde ela provavelmente ficaria hospedada em Lisboa, e a frase "[motiv]os da viagem e provas respectivas Transito para o Bra[sil]”. Desta forma, ficamos sabendo que Hildegard apenas transitaria por Portugal, tendo como destino o Brasil.

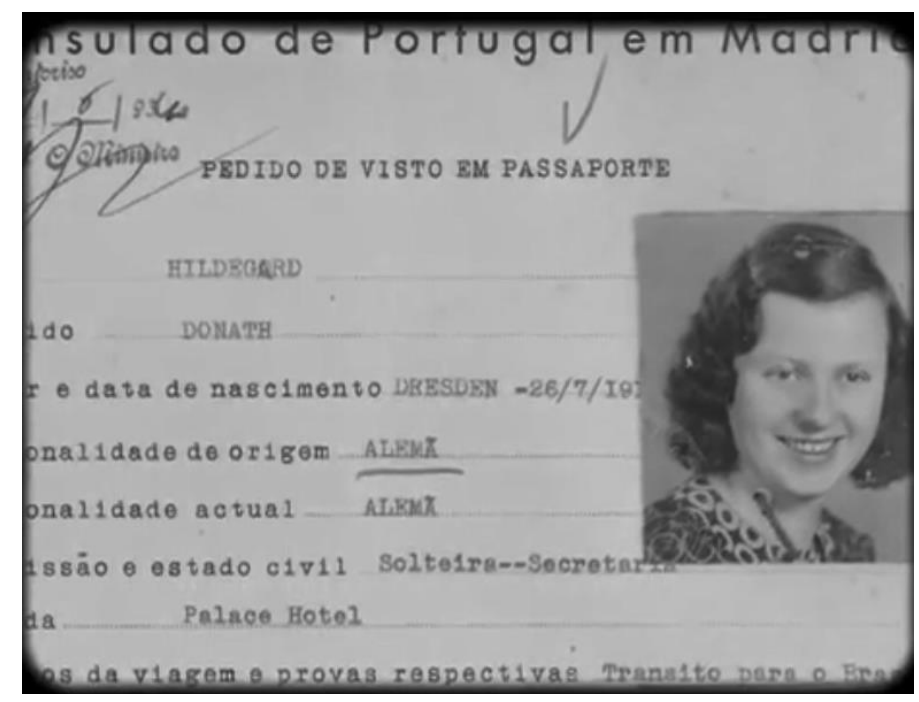

Figura 43: Pedido de visto em passaporte da alemã Hildegard Donath ao Consulado de Portugal em Madrid. Motivo da solicitação: trânsito para o Brasil.

A presença da fotografia de uma jovem sorridente, com o olhar acanhado, que se furta de encarar a lente da câmera, revela o elemento humano por trás de um pedido burocrático. Quando o olhar do espectador descobre o olhar tímido de Hildegard há uma identificação por parte dele, gerando, em cada observador, uma possibilidade de efeitos extraído desse contato, ou, aquilo que Xavier chama de "verdadeira orquestração" (XAVIER, 2003, p. 36). Caso o pedido de visto fosse exibido na tela sem a fotografia da jovem, seria menos provável a possibilidade da identificação por parte do espectador. 
Assim, a exibição da fotografia faz com que enxerguemos a solicitante como um ser humano real e não apenas como um número. Este efeito sensibiliza o espectador a ponto de ele poder perguntar os motivos de Hildegard ter feito o pedido de visto na Espanha e não na Alemanha (ela já teria fugido de seu país anteriormente?), ou, por exemplo, em qual cidade brasileira ela teria desembarcado e se fixado (estaria alguém a sua espera no Brasil? - teria ela viajado sozinha ou com algum membro da família?).

O efeito da exibição das fotografias desses refugiados passa a ser mais importante do que as informações que estão registradas nos formulários. Podemos constatar este fato ao perceber que, na sequência em análise, a câmera passa a dar ênfase cada vez mais às pessoas do que às informações a seu respeito. Há imagens que mostram essencialmente o rosto do solicitante, ocultando seu nome, nacionalidade ou outros dados. Isso fica evidente com várias fotografias, mas damos destaque ao retrato de uma menina de aproximadamente dez anos, cuja identidade ignoramos (Figura 44). A única pista na imagem é de que, talvez, o pedido tenha sido feito na Holanda, pela presença da palavra holandesa "paspoort" (passaporte).

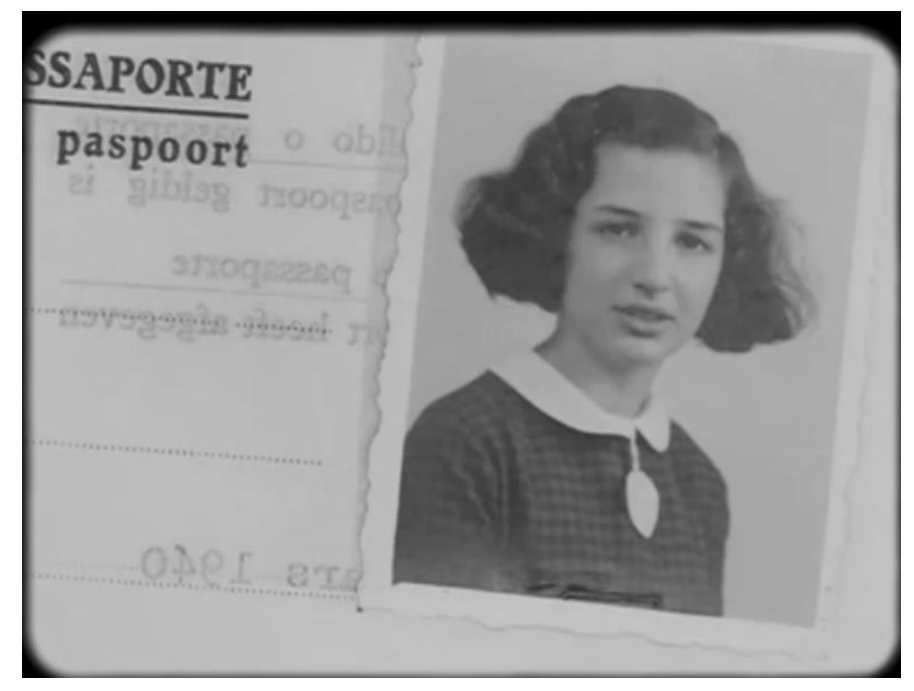

Figura 44: Menina requerente de visto de entrada para Portugal.

Dessa forma, ao recuperar nos arquivos esses documentos consulares e, ao exibir fotografias dos rostos desses requerentes, a montagem de Fantasia Lusitana proporciona a possibilidade de identificação com aquelas pessoas por parte de quem o assiste, fazendo com que o ponto de vista dos refugiados seja valorizado em detrimento à divulgação da propaganda salazarista. Passaremos agora para a análise do papel da câmera na filmagem de fotografias. 


\subsubsection{A câmera que direciona o olhar do espectador}

Ainda dentro do âmbito das fotografias, Fantasia Lusitana recupera muitas imagens que foram publicadas em jornais e revistas portugueses da época. Dentre elas, gostaríamos de destacar algumas que retratam jovens com trajes de banho, ilustrando reportagens acerca de locais turísticos em Portugal.

Por se tratarem de fotos, isto é, imagens estáticas, a câmera cinematográfica desempenha um papel fundamental na construção da narrativa, pois ela direciona o olhar do espectador para determinados pontos, ou seja, ela é a responsável por controlar aquilo que o espectador vê. Por outro lado, ela acaba por ocultar outras partes que não são interessantes à construção da narrativa.

O percurso que a câmera faz pelas páginas dessas revistas está relacionado ao processo de composição e montagem do documentário, bem como ao argumento do filme, que, conforme temos discutido, visa desconstruir a propaganda salazarista. A respeito do papel da câmera, Susan Sontag (2004) explica que

No cinema [...] a câmera olha por mim - e me obriga a olhar, deixando a mim, como única opção, não olhar. Além disso, o filme condensa em minutos algo que leva horas para acontecer, deixando apenas partes interessantes, apresentadas de um modo interessante, ou seja, com o intuito de provocar ou de chocar. O dramático é dramatizado, pela didática da composição e da montagem (SONTAG, 2004, p. 133).

A criação de contrastes abordado pela intelectual pode ser aplicada às duas camadas que integram Fantasia Lusitana uma vez que o contexto do documentário abrange uma Europa que sofre com a guerra em contraponto à construção de uma imagem de Portugal como "oásis de paz”, veiculado pela propaganda do Estado Novo.

Em outras palavras, ao condensar no tempo do filme o que levaria muito mais tempo na vida real, a câmera intensifica o que é mostrado, ou seja, o que é exibido ganha maiores proporções por ser previamente selecionado, recortado, direcionado - algo que não ocorreria com o observar do olho humano em imagens cotidianas naturais.

O professor Ismail Xavier também aborda a questão da câmera em relação ao olho biológico. Ele explica que

Há entre o aparato cinematográfico e o olho natural uma série de elementos e operações comuns que favorecem uma identificação do meu olhar com o da câmera, resultando daí um forte sentimento da presença do mundo emoldurado na tela, simultâneo ao meu saber de sua ausência (trata-se de imagens, e não das próprias coisas). [..] A imagem que recebo compõe um mundo filtrado por um olhar exterior a mim, que me organiza uma aparência das coisas, estabelecendo uma ponte mas também se interpondo entre mim e o mundo. 
Trata-se de um olhar anterior ao meu, cuja circunstância não se confunde com a minha na sala se projeção (XAVIER, 2003, p. 35).

Ao diferenciar os processos de captação e interpretação de imagens pelo olhar da câmera e pelo olhar humano, Xavier introduz a problemática da seleção do que é observado. Em outras palavras, a observação de um mesmo objeto adquire dimensões diversas se ela ocorrer por meio do olho natural (no ambiente em que se encontra) ou a partir de uma sala de projeções, uma vez que, neste segundo cenário, o observador não tem mais o poder de escolha do que será visto e em que tempo. Entretanto, a cassação dessa capacidade parece não ser encarada apenas como algo negativo pelo acadêmico, pois ele também versa sobre vantagens proporcionadas pelo recorte da câmera:

Como espectador, tenho acesso à aparência registrada pela câmera sem o
mesmo risco ou poder, ou seja, sem a circunstância. Contemplo uma
imagem sem ter participado de sua produção, sem escolher ângulo, distância,
sem definir uma perspectiva própria para observação. Ao contrário das
situações de vida, em que estou presente ao acontecimento, na sala de
espetáculos, já sentado, não tenho o trabalho de buscar diferentes posições
para observar o mundo, pois tudo se faz em meu nome, antes de meu olhar
intervir, num processo que franqueia o que talvez de outro modo seria,
para mim, de impossível acesso. Espectador de cinema, tenho meus
privilégios. Mas simultaneamente algo me é roubado: o privilégio da escolha
(XAVIER, 2003, p. 35-36, grifos nossos).

Em suma, Xavier sintetiza a experiência de ser espectador em uma sala de projeções como algo positivo e negativo. Em outras palavras, as vantagens estariam no fato de dirimir os riscos presentes na observação in loco (por exemplo, enxergar detalhes da vida selvagem ou ver de perto uma catástrofe natural) e de oferecer comodidade ao observador por meio de uma visão privilegiada, que, talvez não fosse possível com o olho natural. Por outro lado, a maior desvantagem seria abdicar do poder de escolha do que se deseja ou não ver, e em que tempo o fazer.

Passando para a análise de excertos do documentário em que a câmera controla o olhar do espectador, retomamos às fotografias das revistas que haviam sido mencionadas no início desta seção. As páginas dessas publicações acabam por conter mais de uma imagem, diagramadas de forma a chamar a atenção de seus leitores, além da presença de frases que provavelmente são títulos de reportagens ou legendas para as imagens. É pertinente dizer que, juntamente à essas fotos, o espectador ouve no idioma francês (legendado em português) trechos das reminiscências de Saint-Exupéry a discorrer sobre o alheamento de Portugal perante a realidade bélica circundante e a fragilidade que Lisboa demonstrava em confronto aos exércitos das outras nações. 
Em uma sequência que começa aos $34 \min 45 \mathrm{~s}$, a câmera capta a imagem do rosto de duas mulheres que sorriem, deitadas ao chão, com roupas de banho. O foco da câmera gira em círculo, no sentido anti-horário, como alguém que girasse o pescoço para obter um melhor ângulo da cena. Em seguida, surge a imagem de outra página de revista com destaque para três jovens vestidas com trajes de banho, que caminham tranquilamente por uma praia. Seus braços estão entrecruzados, sendo que as jovens das extremidades olham para a câmera e sorriem, ao passo que a mulher que se encontra no centro parece ignorar a presença do fotógrafo, olhando para o seu lado esquerdo.

Nesta imagem, a câmera faz o movimento de baixo para cima, ou seja, o olhar da lente cinematográfica começa pela parte inferior da página, mostrando inicialmente as pernas das modelos e se dirige para a parte de cima, em cujo canto superior esquerdo há a fotografia de uma praia cheia de banhistas e guarda-sóis. Entretanto, ao fazer o movimento para cima, a câmera acaba por focar no texto que se encontra no canto superior direito: "Costa do Sol - paraíso de belezas" (Figura 45).

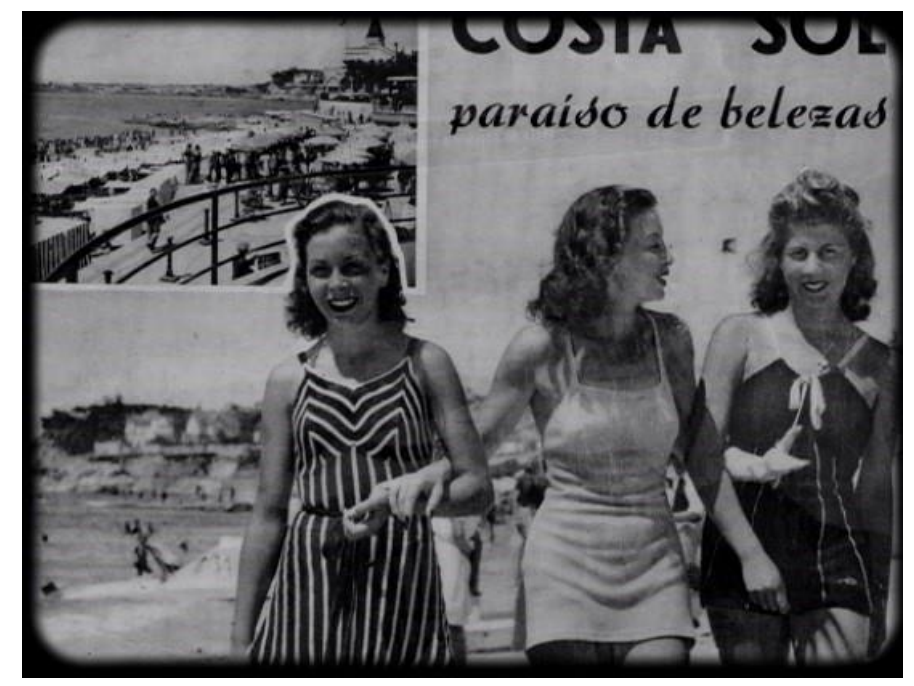

Figura 45: Página de revista portuguesa com destaque para jovens que caminham em uma praia. Lê-se no título "Costa do Sol - paraíso de belezas".

Este trecho é bastante emblemático pois propõe dois níveis de leitura, ou seja, o primeiro sendo aquele destinado aos leitores portugueses da revista na década de 1940, que potencialmente poderiam procurar aquela localidade para passar suas férias. $\mathrm{O}$ texto apresentado acaba sendo propositalmente dúbio, pois as "belezas" tanto podem se referir à localidade litorânea quanto às jovens modelos representadas naquela foto, o que correspondia ao efeito desejado pelo editor da revista a seu tempo. Por outro lado, o segundo nível de leitura, aquele proposto pela montagem, força o espectador a ler o texto 
ali impresso, ou seja, a divulgação da Costa do Sol, ao mesmo tempo em que SaintExupéry está a dizer que "[...] por trás do seu sorriso, Lisboa parecia-me mais triste do que as minhas cidades apagadas" (FANTASIA LUSITANA, 2010, 34:40 - 34:44), lembrando ao espectador a presença da guerra muito perto dali. O "sorriso" de Lisboa coincide com o sorriso das modelos na foto.

A imagem abaixo (Figura 46), também proveniente de revista, exibe, em primeiro plano, uma mulher com trajes de banho sentada em uma espécie de parapeito ou gradil. A modelo sorri e mantém o olhar distante, como a contemplar algo agradável. Ao fundo, há uma praia com alguns banhistas, várias barracas e tendas e, em letras maiúsculas, a palavra "Estoril". A página está diagramada de modo a exibir mais duas fotografias em sua parte superior, porém, a montagem do documentário não as revela, mostrando apenas fragmentos dessas imagens e a legenda para essas duas fotos: "Dois aspectos da praia do Estoril, onde se respira optimismo e alegria de viver" (FANTASIA LUSITANA, 2010, $34: 45)$.

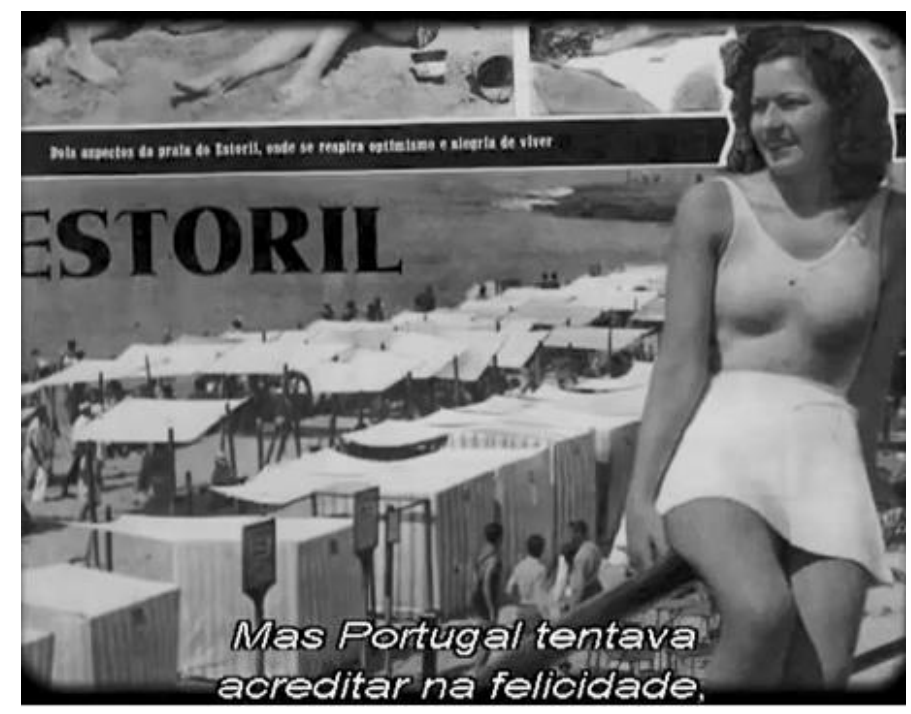

Figura 46: Página de revista com reportagem sobre Estoril em plena Segunda Guerra Mundial, em cuja legenda se lê: "Dois aspectos da praia do Estoril, onde se respira optimismo e alegria de viver".

A imagem adquire movimento através do deslocamento da câmera, que gira em sentido horário, endireitando o texto para que o espectador possa ler a legenda das fotos mais facilmente. Embora a revista tenha sido publicada e destinada aos leitores de então, a montagem de Fantasia Lusitana propõe a desconstrução daquele discurso, que nada mais era do que a extensão do discurso salazarista de que tudo estava bem em Portugal (apesar da guerra algures). Este processo ocorre através da coincidência da imagem com 
a banda sonora em francês das anotações de Saint-Exupéry, fazendo com que, ao mesmo tempo em que o espectador veja a foto da jovem na praia em primeiro plano, em um lugar "onde se respira optimismo e alegria de viver", a legenda em português exiba: "Mas Portugal tentava acreditar na felicidade" (FANTASIA LUSITANA, 2010, 34:47), criando uma oposição de ideias.

Os dois textos exibidos concomitantemente na tela são divergentes, pois a legenda na revista fala de "optimismo e alegria de viver" ao passo que a fala legendada de Exupéry denuncia que "Portugal tentava acreditar na felicidade". Em outras palavras, o discurso de que em terras portuguesas se gozava paz e alegria é desconstruído através da fala estrangeira inserida através da montagem, revelando o viés da imprensa portuguesa.

Se as imagens anteriores não abordam de forma direta a guerra, concedendo este papel a Saint-Exupéry, o mesmo não se pode dizer da próxima fotografia em tons de sépia. Nela, uma modelo com trajes de banho está abraçada à uma boia inflável em formato de golfinho, em pé, no que parece ser a borda de uma piscina, dada a presença de cadeiras e de um guarda-sol (Figura 47).

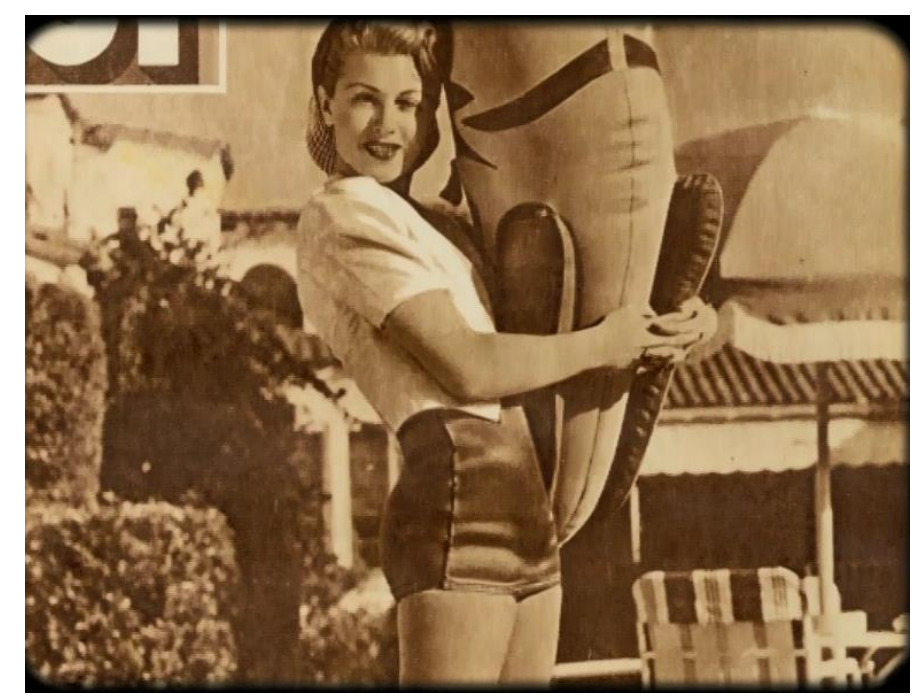

Figura 47: Modelo abraçada a boia cujo formato remete à representação de uma bomba.

A câmera se desloca de cima para baixo, direcionando o olhar do espectador para a parte inferior da página, em cujo canto direito há um círculo vermelho (Figura 48) contendo os seguintes dizeres: "O bombardeamento de Londres - neste numero [sic] grande reportagem" (FANTASIA LUSITANA, 2010, 34:57). 


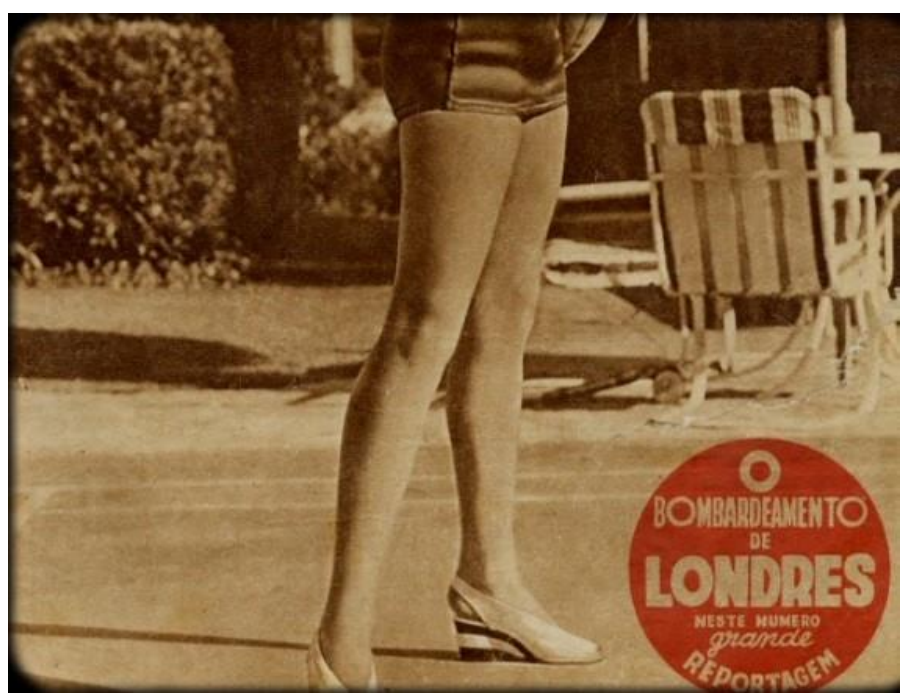

Figura 48: Destaque para a chamada da reportagem sobre o bombardeio de Londres em 1940.

O deslocamento da câmera em direção ao texto revela aquilo que a montagem do documentário deseja que o espectador veja, isto é, ela conduz o seu olhar pela tela, selecionando a trajetória e os elementos a serem revelados. É pertinente lembrar que a própria revista quis chamar a atenção de seu leitor à época, ao destacar a notícia do bombardeio de Londres dentro de um círculo vermelho, deixando o nome da cidade centralizada e em caixa alta. A coloração deste círculo sugere atenção, remetendo à cor de uma placa de trânsito com o sinal de parada obrigatória, fazendo com que o potencial comprador parasse, lesse a chamada e desejasse adquirir a revista.

Por outro lado, ao movimentar a câmera do rosto da modelo até os seus pés, a montagem do documentário reserva para o último instante a alusão à guerra, gerando um contraste entre a alegria vivida em Portugal e a existência de um mundo bélico não distante dali. Além disso, pelo fato de o golfinho inflável recordar o formato de uma bomba, Canijo talvez tenha desejado dar movimento a esse objeto através do deslocamento da câmera, simulando o cair de uma bomba. É o que pode ser inferido através de entrevista ao jornalista Vasco Câmara:

[...] uma menina agarrada à bóia que parece uma bomba mas é um golfinho, desce-se pelas perninhas da menina abaixo e cá em baixo diz: "Bombardeamento de Londres. Toda a reportagem no interior". Essa imagem é genial. A guerra era outro mundo. Não tinha nada a ver connosco, para quê preocuparmo-nos com a guerra? (CÂMARA, 2010).

Por fim, esta sequência de fotos retratando um Portugal alegre e jovial, que se diverte nas praias e piscinas é finalizada com uma imagem irônica. Trata-se de uma fotografia a respeito de um flagrante inusitado (Figura 49): um policial, com as mãos na 
cintura, aborda um grupo de pessoas vestidas com trajes de banho. Dentre eles, há a) uma mulher em pé, também com as mãos na cintura e a cabeça levemente reclinada para a direita, prestando atenção no que o policial diz; b) um homem de óculos escuros, sentado, para quem o policial está olhando e que também fita o policial; c) uma pessoa deitada ao lado esquerdo do homem, cujas pernas são as únicas parte visíveis na fotografia, possivelmente a infratora do delito que é revelado na legenda da foto: "uma alça do fato descida... ou como se apanha uma multa de 300 escudos (FANTASIA LUSITANA, 2010, 35:00).

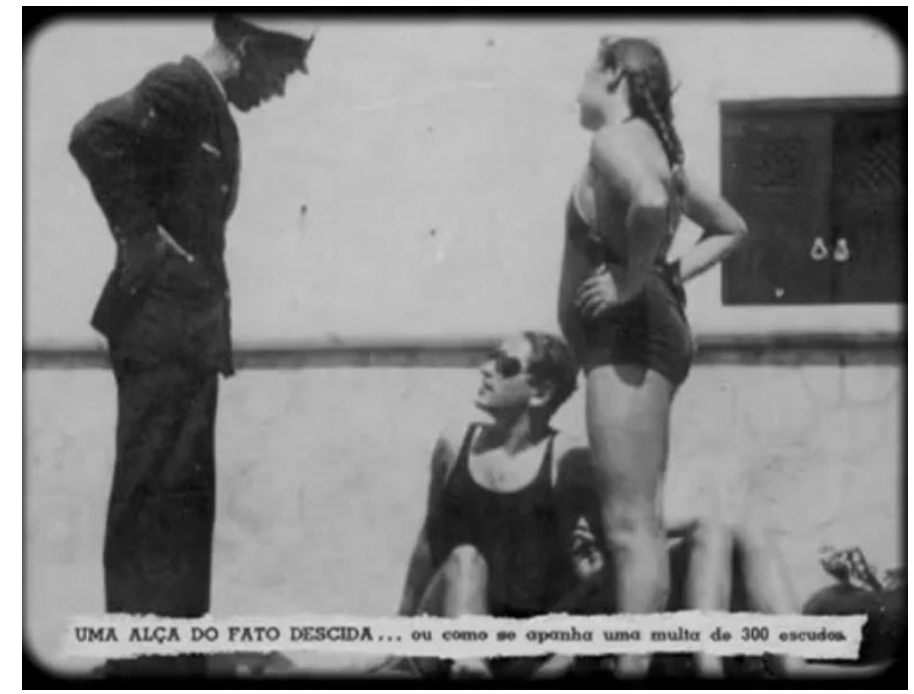

Figura 49: Fotografia de uma abordagem policial em cuja legenda se lê: "Uma alça do fato descida... ou como se apanha uma multa de 300 escudos".

Este tipo de imagem revela uma das preocupações do governo salazarista, isto é, fiscalizar e controlar os corpos da população a fim de preservar os ditos valores e bons costumes. Segundo Fernando Rosas (2001), esses princípios do Estado Novo,

\begin{abstract}
Significavam uma moral de (re)educação, de regeneração colectiva e individual, da qual resultaria, pela acção do Estado nos vários níveis das sociabilidades públicas e privadas, o moldar desse especial «homem novo» do salazarismo, capaz de interpretar e cumprir a alma e o destino ontológico da nação que o antecedia e se lhe sobrepunha, vinculando-lhe atitudes, pensamentos e modos de vida, redefinindo e subordinando o particular ao império do «interesse nacional». Não só, nem principalmente, como sujeição do individual ao colectivo, mas como padronização tendencial dos espíritos e dos «modos de estar» de acordo com os «valores portugueses» de sempre, que o regime definia, representava e tinha como missão fazer aplicar (ROSAS, 2001, p. 1.037).
\end{abstract}

Dessa forma, embora a imprensa portuguesa da época divulgasse e promovesse praias e locais turísticos estampando belas mulheres em suas páginas, os trajes que elas usavam estavam adequados à moral proposta pelo regime. A partir do momento que esta 
lógica é contrariada, o controle e a censura são exercidos a fim de assegurar a manutenção desse "homem novo" proposto pelo Estado Novo e analisado por Rosas (2001).

A inclusão da foto da abordagem policial em razão da alça de maiô descida finaliza uma sequência de imagens de pessoas se divertindo, sobretudo, em praias portuguesas. Sobrepostas à essas fotografias, a montagem apresenta alguns trechos do testemunho de Saint-Exupéry acerca da fragilidade portuguesa diante da guerra, gerando um contraste entre as fotos e a fala do escritor francês. Por este motivo, esta última imagem possui alguns aspectos que a tornam emblemática.

Primeiramente, ao publicar este tipo de flagrante, notamos como a imprensa portuguesa agia a serviço do regime salazarista, pois "ensinava" a população "como não apanhar uma multa de 300 escudos" mesmo de forma leve, ou seja, a revista corroborava a ideologia em voga, veiculando notícias caras ao regime. Além disso, a presença de pessoas felizes e sorridentes nas revistas portuguesas somente foi possível pelo fato de Portugal não ser partícipe da guerra, embora a população soubesse de sua existência como um evento que ocorria longe de suas terras, logo, que não lhes dizia respeito. A propaganda afirmava que, com Salazar, a população estava segura devido à sua política internacional. Em suma, essas fotografias denotam o contraste que acontecia entre Portugal e os países beligerantes: enquanto no primeiro a propaganda mostrava uma população que se divertia despreocupadamente, em Londres, como lembra a capa da revista, vidas humanas eram ceifadas através dos bombardeios aéreos.

Assim, ao incluir a fotografia do policial abordando o grupo de banhistas, a montagem expõe o tipo de preocupação ínfima por parte do governo salazarista enquanto ocorre a guerra em outras nações. Esta imagem revela a alienação vivida em Portugal, pois, se por um lado o regime estava preocupado em censurar a forma como os portugueses se vestiam, por outro, nos países beligerantes, pessoas eram mortas, feriadas, desapropriadas e tinham que abandonar suas terras para sobreviver, revelando o grande abismo que separava essas duas realidades. Preocupar-se com querelas como a "alça do fato" apenas patenteia o clima de ausência de empatia vivido em Portugal perante as vítimas da guerra. 


\section{CAPÍTULO 5: A ASTÚCIA DO REGIME SALAZARISTA}

Veremos agora de que maneira o governo salazarista se apropriou do fim da Segunda Guerra Mundial em benefício próprio, o que, até certo ponto, contribuiu com a manutenção e continuidade do regime até 1974.

Com a eclosão da Segunda Guerra Mundial em 1939, o Estado Novo declarou status de neutralidade, procurando manter-se, de certa forma, próximo tanto de países Aliados quanto de países do Eixo, conforme abordamos no item 1.6 "A "neutralidade" e a "diplomacia" portuguesas" do capítulo 1 deste estudo. Durante os primeiros momentos da guerra ocorrem em Portugal visitas oficiais de militares da marinha do Reino Unido, Alemanha e Itália. Aliás, a presença de alemães, italianos e espanhóis em eventos promovidos pelo regime português era frequente, tanto no âmbito da força militar, quanto por parte de eventos das juventudes nazistas, fascistas e franquistas, como já visto.

Porém, com a proximidade do final do conflito, Portugal abandona sua posição de isenção a começa a se engajar com os países Aliados, conforme explica Ricardo Braga (2005):

\footnotetext{
Com a Segunda Grande Guerra a caminhar para o seu final, alterava-se uma parte significativa da estratégia de alianças engendrada pelo Estado Novo durante os períodos de conflito. Acabada a neutralidade, que noutras alturas tinha permitido a continuidade do regime, os responsáveis pela política externa tinham de escolher, também por razões de sobrevivência, os seus aliados do lado dos vencedores (BRAGA, 2005, p. 157).
}

Dessa forma, após o término do conflito no continente, os então países Aliados, bem como aqueles que tinham sido ocupados pelos nazistas, celebram o $V$-E Day, ou seja, o Dia da Vitória na Europa, ocorrido em 08 de maio de 1945. Fantasia Lusitana apresenta um trecho (a partir dos 54min17s) com fotografias de capas de diversos jornais que estampam este evento. São eles: o americano The Stars and Stripes, o francês Le Monde, o americano The New York Times, o britânico Daily Mirror e o português $O$ Século (Figura 50). No início desta sequência, juntamente com a primeira imagem, a montagem insere a canção We'll Meet Again, cantada pela inglesa Vera Lynn, título musical frequentemente associado à separação entre os soldados que iam lutar na guerra e seus familiares, e cuja tradução é uma promessa de regresso: "Iremos nos encontrar novamente". 


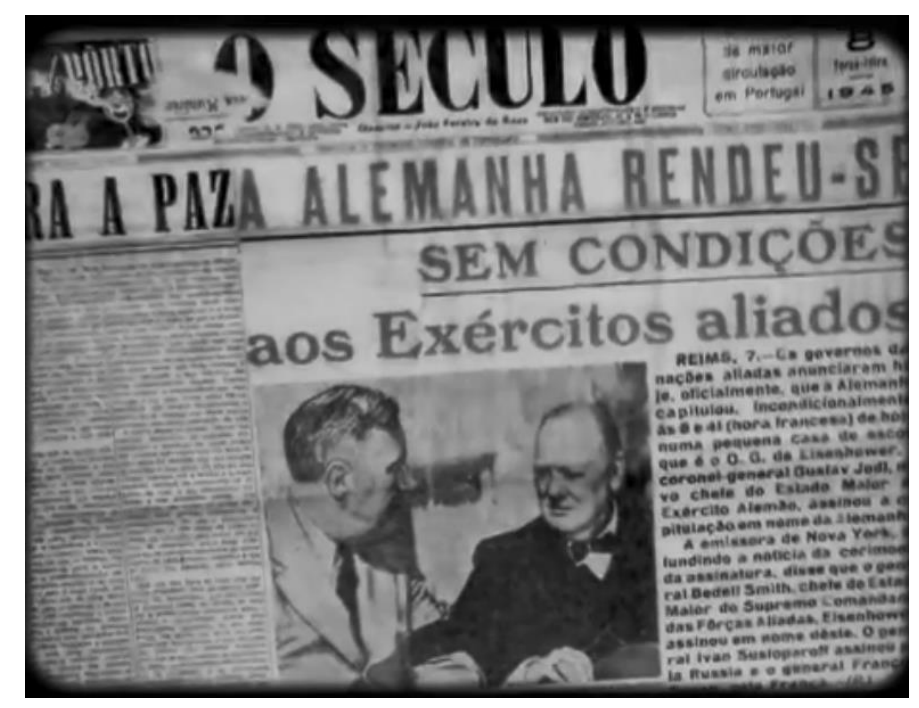

Figura 50: Imagem da capa do jornal $O$ Século, que estampa a rendição alemã aos exércitos aliados.

Logo após a apresentação das capas de jornal, que conduzem e remetem o espectador para o fim do conflito na Europa, vemos imagens de Portugal a partir de uma gráfica que imprime tiragens do jornal Diário de Lisboa. Há uma aglomeração de ardinas (vendedores ambulantes de jornais) em frente à administração do referido diário (Figura 51), ávidos por obter mais cópias do periódico devido à grande demanda por notícias sobre o fim da guerra.

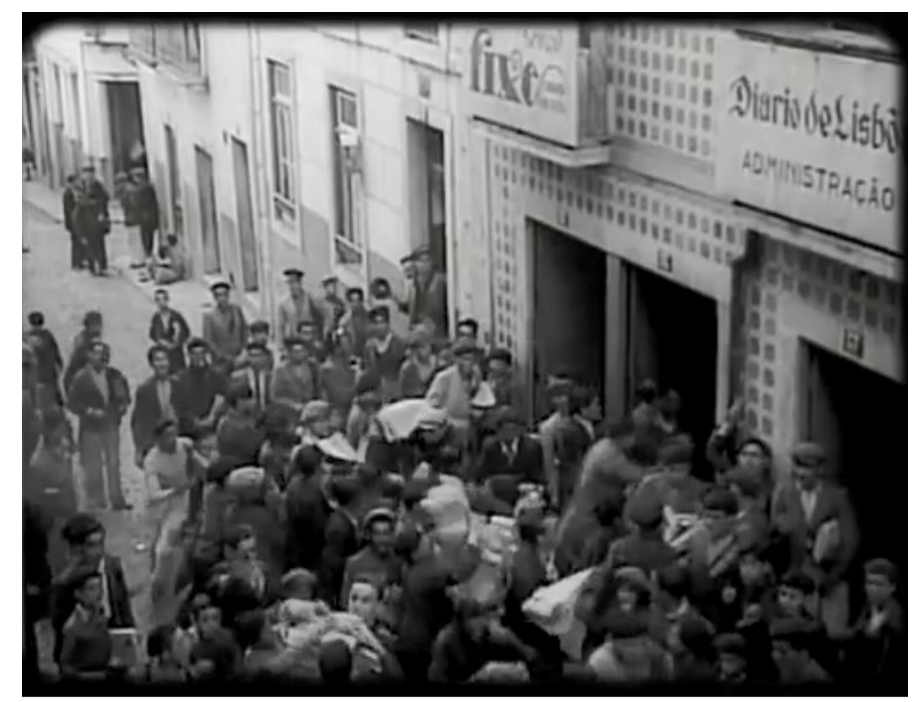

Figura 51: Aglomeração de ardinas em frente à administração do jornal Diário de Lisboa devido a demanda por notícias do fim da guerra na Europa.

As imagens que sucedem mostram vários ardinas a correr com pilhas de jornais, bem como uma concentração de pessoas disputando um de seus exemplares (Figura 52). Não obstante o clima de alegria com o fim do conflito ter ocorrido por quase toda Europa, as imagens do alvoroço causado pela busca de notícias são de Portugal, demonstrando 
que, embora não tivessem vivido a guerra de forma direta, a curiosidade por parte dos portugueses era grande.

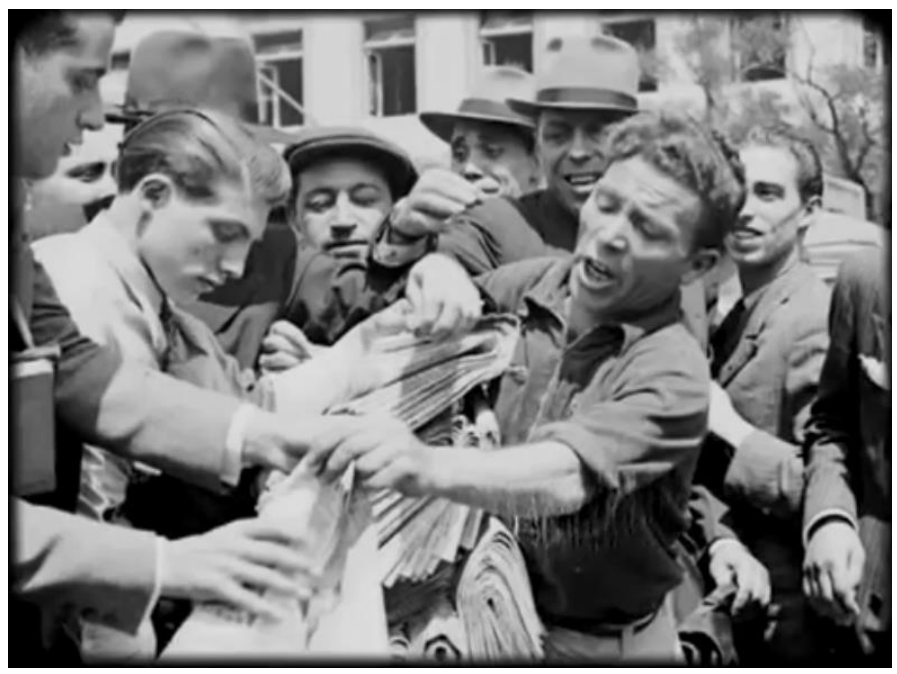

Figura 52: Portugueses disputam jornais que trazem notícias do término da Segunda Guerra Mundial na Europa, ocorrido em 08 de maio de 1945.

Apesar desse interesse, "As manifestações de regozijo pela vitória dos Aliados e de afirmação democrática das massas populares não foram noticiadas pelo Jornal Português" (BRAGA, 2005, p. 158), revelando, por parte do regime, um desejo de abafar tais informações. Assim, constatamos que o fato dessas imagens terem sido selecionadas para compor Fantasia Lusitana não é fortuita, demonstrando que houve intenção por parte de Canijo de levar essa informação ao espectador, de certa forma, restituindo o que fora roubado da população daquela época.

Após exibir o entusiasmo gerado pelo fim da guerra em Portugal, Fantasia Lusitana passa a retratar fotografias de multidões que saíram às ruas para celebrar o que ficou conhecido por Dia $V$. Nesta sequência, vemos pessoas empunhando bandeiras inglesas, americanas, de outras nações aliadas, bem como portuguesas. Nas fotos que priorizam os rostos, vemos faces alegres, sorridentes, cheias de esperança. Muitos se abraçam e outros levantam os braços com os dedos formando a letra $\mathrm{V}$, simbolizando a vitória dos Aliados (Figura 53). 


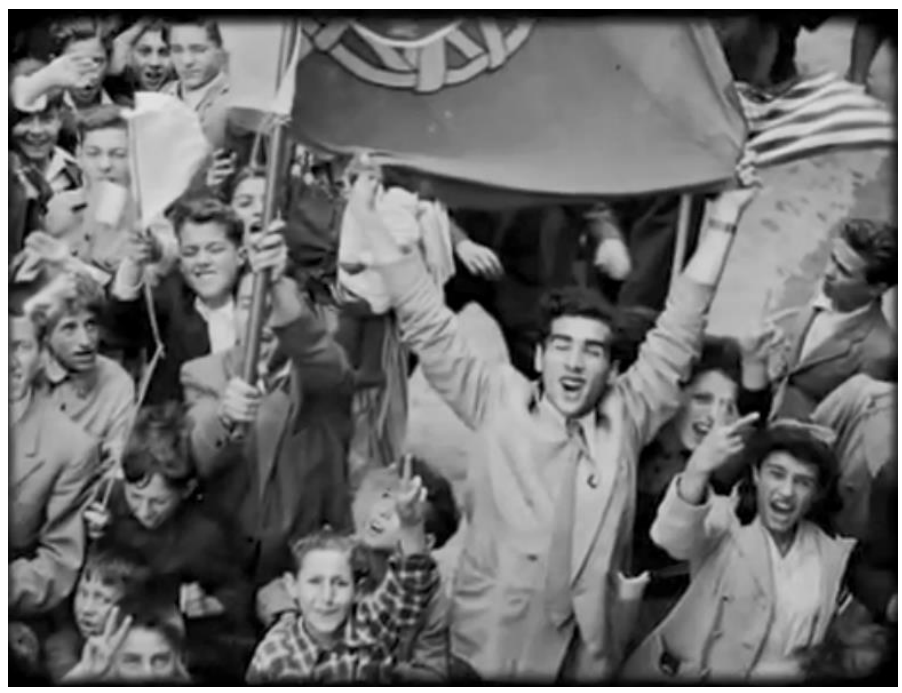

Figura 53: Fotografia de pessoas que saíram às ruas para comemorar o Dia $V$, isto é, o Dia da Vitória na Europa após a rendição dos nazistas em 08 de maio de 1945. Destaque para as bandeiras de Portugal e dos Estados Unidos, bem como para o símbolo gestual de $\mathrm{V}$, representando a vitória dos aliados.

Com a vitória dos Aliados e a queda dos regimes autoritários nazista e fascista, o Estado Novo abandona a prática pública da saudação romana. Este fenômeno é perceptível claramente no desenrolar de Fantasia Lusitana, conforme aponta o realizador em entrevista a Ana Margarida de Carvalho. No início do documentário, há muitas cenas com imagens de homens, mulheres e jovens, principalmente da Mocidade Portuguesa, executando a saudação. Há "muito bailarico, muita festa e bandeirinha, muitos braços esticados - que se encolheram prudentemente depois da guerra, 'deu-lhes uma artrose colectiva', ironiza o realizador" (CARVALHO, 2010).

A possibilidade da queda do regime de Salazar era muito alta, conforme lembra Ricardo Braga:

Em Portugal tinha-se gerado um forte movimento a favor da democracia. Perante a convicção de que a mudança chegaria aos dois países peninsulares governados por forças antidemocráticas, a oposição democrática aproveitava os momentos iniciais de hesitação e de expectativa de um Governo remetido à defensiva para pedir eleições livres. Acreditava-se em Portugal que os Aliados iriam prosseguir um [sic] política de boicotes à semelhança da atitude tomada para com a Espanha de Franco (BRAGA, 2005, p. 158).

É pertinente lembrar que, enquanto as imagens de comemoração popular são exibidas, a canção We'll Meet Again continua a ser tocada, funcionando como elemento corroborativo de afirmação do clima de esperança surgido com a vitória dos Aliados. Entretanto, quando o espectador começa a se identificar com a alegria e a confiança sentida por aquelas pessoas ali retratadas, ocorre uma quebra de expectativa. De modo abrupto, a montagem interrompe a sequência de imagens e um intertexto surge 
desavisadamente, com os seguintes dizeres: "A manifestação a Carmona e a Salazar pela paz portuguesa" (FANTASIA LUSITANA, 2010, 55:25). A agradável canção, símbolo do fim da guerra, é substituída por uma espécie de fanfarra e imagens feitas pelo regime salazarista voltam a ser exibidas.

\subsection{O Dia S, uma resposta ao Dia $V$}

A queda dos regimes autoritários na Itália e na Alemanha fez com que a parcelas da população portuguesa vislumbrassem a possibilidade de o mesmo ocorrer em seu país. É importante contextualizar que, pouco antes do término da guerra, o governo português vinha sofrendo sinais de desagrado por partes de certas camadas da sociedade. Segundo o pesquisador Ricardo Braga,

No final de 1944 o Estado Novo viveu momentos de sobressalto. A insatisfação
da instituição militar parecia estar a atingir o ponto mais alto. O
descontentamento dos oficiais pelo anunciado não aumento dos ordenados do
funcionalismo civil e militar levou ao ressurgimento de um sentimento
conspiratório que abarcava diversas facções do Exército (BRAGA, 2005,
p.153).

Pouco tempo mais tarde, a vitória dos aliados em maio de 1945 acalorou os ânimos daqueles que desejavam a queda de Salazar. Conhecedor deste cenário, o arguto ditador português, através de órgãos ligados a seu governo, promoveu uma manifestação que teve a pretensão de parecer espontânea e popular. Braga explica que,

Receando que os militares pudessem reactivar a conspiração, e com as manifestações populares de cunho antifascista a acontecerem um pouco por todo o País, o regime vê-se obrigado a passar do embaraço para a acção. Entre os eventos realizados para o efeito, sobressai a manifestação de agradecimento a Salazar pela paz, convocada pela Associação Central de Agricultura e organizada pelo Ministério do Interior (BRAGA, 2005, p. 153-154).

Este evento pró-regime ocorreu em 19 de maio de 1945, ou seja, apenas onze dias após o Dia $V$. Ele teve como intuito não apenas tirar o foco da população em relação à vitória dos aliados, mas, principalmente, promover a imagem de Salazar como o responsável por Portugal ter se mantido em paz enquanto houve a guerra. Como bem explica Braga, esta manifestação não surgiu a partir de iniciativa popular, como a propaganda salazarista veiculou. Ademais, após este episódio, o reconhecimento do ditador como agente da paz portuguesa se fortaleceu:

O discurso veiculado no período da ditadura sobre o fim da II Guerra Mundial realça o papel de Salazar no processo de manutenção de uma posição neutra, tendo impedido a participação portuguesa na guerra. A população viu-se 
envolvida em cerimónias para louvar Salazar como o salvador da nação (MACEDO, BASTOS e CABECINHAS, 2016, p. 46).

Um dos instrumentos que talvez tenha contribuído com a popularização dessa ideia foi o Jornal Português, veículo patrocinado pelo SPN já abordado nesta dissertação, que, em seu número 52, intitulado A Manifestação a Carmona e Salazar pela Paz Portuguesa, abordou essa temática. Algumas cenas desta edição recuperadas em Fantasia Lusitana invadem a sequência de comemorações legitimamente populares ocorridas em decorrência da vitória dos aliados. Em termos de montagem, as cenas do Dia V são substituídas pelas imagens da manifestação pró-Salazar, ou seja, a atmosfera internacional de alegria e esperança que havia sido construída pela narrativa fílmica é interrompida pelas imagens do evento nacionalista, fazendo com que o foco recai novamente sobre Portugal.

Dessa forma, passaremos agora à análise de trechos do documentário de Canijo que utilizam imagens dessa manifestação. Em primeiro lugar, o que chama a atenção é a presença maciça de pessoas oriundas das mais diversas localidades portuguesas. Isso se faz evidente através do enfoque dado às insígnias prestigiando os nomes dos municípios, tais como Beja, Chaves (Figura 54) ou Barreiro, bem como através da narração do locutor:

No dia 19 de maio, representantes de todos os municípios portugueses foram
ao Palácio de Belém cumprimentar o chefe do Estado e manifestar-lhe a sua
gratidão. É que o povo português tinha uma dívida em aberto desde aquele
triste mês de setembro de 1939, em que a guerra voltou a assolar o mundo e
Portugal saiu ileso da tremenda catástrofe, sem a menor quebra dos seus
compromissos seculares, sem a menor beliscadura na sua honra nacional
(FANTASIA LUSITANA, 2010, 55:38 - 56:13).

Conforme pudemos verificar, a alocução parte do pressuposto de que todos os munícipios portugueses enviaram representantes àquele evento afim de cumprimentar e agradecer ao Chefe de Estado. Dessa forma, a construção da narrativa propagandística concentra em um só local, isto é, o Palácio de Belém, cem por cento do território nacional, como forma de evidenciar que a aprovação do governo era unânime. Ademais, o locutor informa que a população tinha uma dívida a ser saldada desde o início da guerra, em setembro de 1939, uma vez que Portugal passou incólume durante os anos de conflito. 


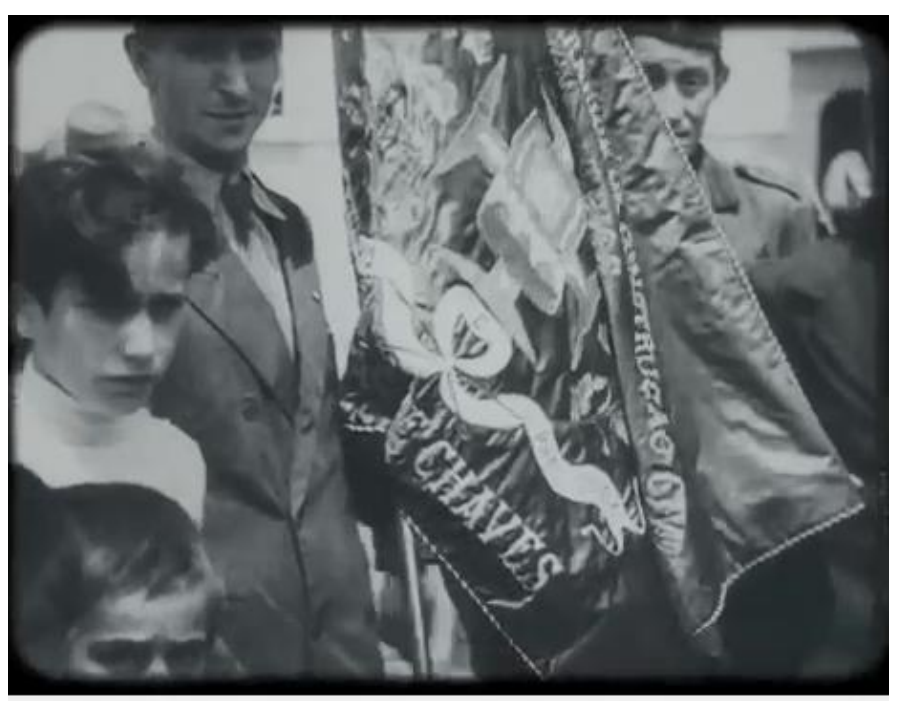

Figura 54: Imagem do noticiário cinematográfico intitulado $A$ Manifestação a Carmona e Salazar pela Paz Portuguesa que prioriza o enquadramento da insígnia de Chaves.

Embora esta possa não ser a percepção da população em relação aos anos de guerra dado o alheamento vivido em Portugal neste quesito, notamos a óbvia construção de uma narrativa e a criação de uma dívida moral endereçada aos portugueses. Ademais, a forma como o país passou pelos anos de guerra é descrita como algo valoroso, já que, segundo a peça propagandística, Portugal, nem de longe, teria sido ameaçado em seus compromissos ou em sua honra. No entanto, sabemos que tal discurso não corresponde à realidade, pois a soberania portuguesa foi ameaçada, sobretudo em relação aos Açores, conforme analisamos no item 1.5 "O recrudescimento da guerra assombra Portugal" do capítulo 1 desta dissertação.

Em seguida, as tomadas passam a se dar em plano aberto, com a intenção de ostentar a magnitude da manifestação. Eventualmente, a câmera foca em alguma faixa com mensagens de apoio ao ditador (Figura 55). A construção narrativa do noticiário de 1945 tem o objetivo de mostrar que Salazar era venerado integralmente pelo povo português. 


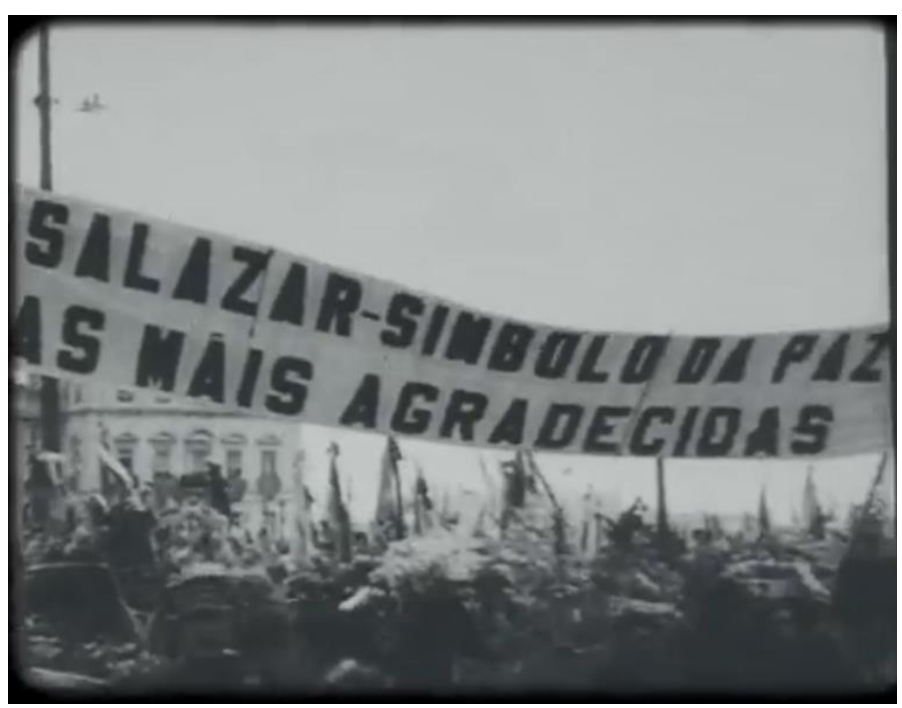

Figura 55: Destaque dado a faixa de apoio a Salazar com os dizeres: "A Salazar - Símbolo da Paz - as mais agradecidas".

Acerca da criação da imagem de que a população de Portugal havia aderido à manifestação de forma coesa, a professora Heloísa Paulo (2011) esclarece:

[...] podemos identificar representantes das mais diversas classes, provenientes das mais diferentes regiões do País. Faixas com afirmações favoráveis ao regime identificam os grupos e as corporações que representam. Desta forma, a divisão corporativa da sociedade encontra-se espelhada na disposição do desfile e das tomadas de cena, oferecendo a ideia de uma ocupação total da área circundante que corresponde à noção de coesão e unanimidade que a mensagem do regime busca transmitir (PAULO, 2011, p. 112).

A pesquisadora dá destaque ao cuidado que a propaganda salazarista teve em querer retratar não apenas todas as regiões do país, mas também todas as camadas da população, em conformidade com a característica corporativista do regime. Entrementes, o locutor continua a narração:

\footnotetext{
O povo português quis pagar essa dívida e fê-lo galhardamente, como costuma. Aquilo, a que alguém chamou o nosso milagre, deve-se principalmente a dois homens, a dois chefes, Carmona e Salazar. Sob a égide do primeiro, a política de Salazar como Presidente do Conselho e Ministro dos Negócios Estrangeiros salvaguardou a nação portuguesa de todos os males que afligiram mais de nove décimos do planeta durante seis anos. Por isso, no Terreiro do Paço, se juntou a mais numerosa multidão que jamais se verificou (FANTASIA LUSITANA, 2010, 56:14-56:57).
}

A construção ideológica da narrativa do Jornal Português, além de ter destinado uma dívida moral à população de Portugal, faz com que essa manifestação simbolize a quitação deste débito, em forma de agradecimento ao ditador pelo falo de Portugal ter "escolhido" a paz. É notório o apontamento de que "mais de nove décimos do planeta" foram atingidos pelo conflito, excetuando Portugal, condição que valoriza o governo português na perspectiva do material propagandístico. Ter se mantido em segurança 
durante esses seis anos e ter saído ileso é chamado pelo locutor de "nosso milagre". De acordo com a crença católica, os milagres são atribuídos a santos; ora, o comentarista são se faz de rogado e revela prontamente que este milagre se deveu a Carmona e a Salazar, com evidente destaque para o segundo.

A esse respeito, nenhumas das faixas exibidas (pelo menos no recorte feito em Fantasia Lusitana) traz o nome do General Carmona, embora ele tenha sido citado pelo locutor. A menção ao Presidente da República nada mais era do que um protocolo, graças à função decorativa que ele exercia, fazendo com que, de fato, os louros fossem destinados a Salazar. Mais adiante, outra faixa revela a presença da cidade do Porto naquele evento, em apoio a Salazar "pelo bem comum" (Figura 56), reforçando a ideia de apoio popular irrestrito.

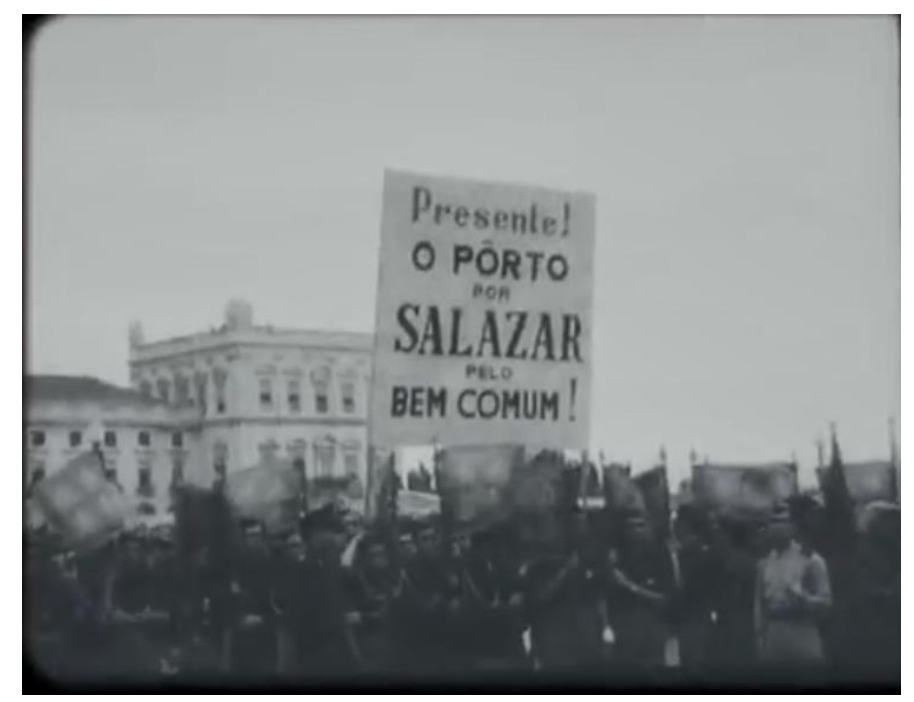

Figura 56: Imagem do Jornal Português número 52, utilizado em Fantasia Lusitana, onde se lê: "Presente! O Pôrto por Salazar pelo bem comum!"

Passamos ao momento em que o ditador fala à população que havia se dirigido até o então Terreiro do Paço (atual Praça do Comércio) para, segundo o Jornal Português, saudá-lo e agradecê-lo. As imagens primam por revelar um Salazar popular, aclamado efusivamente por seus ministros e pelo povo. Em uma determinada tomada, a câmera capta as costas do ditador a cumprimentar a população reunida na praça, quando é possível enxergar a estátua equestre de D. José I na praça (Figura 57). 


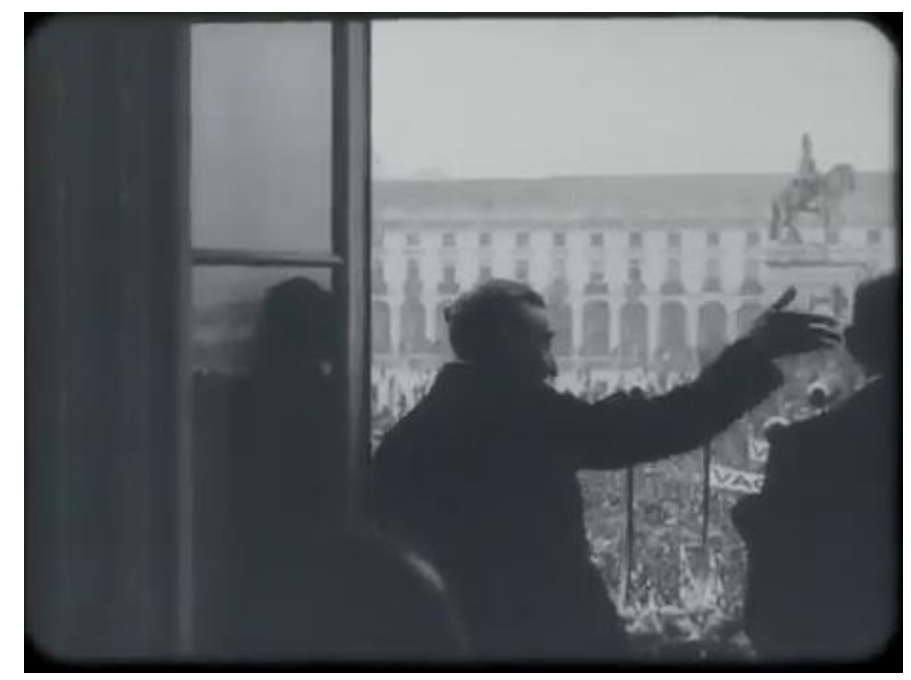

Figura 57: Tomada interna que capta António de Oliveira Salazar em uma sacada a saudar a população que se reunia no então Terreiro do Paço (atual Praça do Comércio) em 19 de maio de 1945.

No entanto, a maioria das tomadas durante a fala de Salazar são externas, primando pela alternância entre a imagem do ditador (em posição privilegiada na sacada), o agrupamento popular e a concentração de embarcações no Rio Tejo. No tocante ao papel das multidões nos documentários pró-regime produzidos daquele período, Heloísa Paulo explica que “Destaca-se a existência de dois tipos de público-actor: o 'povo' em si, presente nos grandes comícios de rua, e os apoiantes mais engagés, que compõem as 'plateias' mais restritas dos comícios políticos da União Nacional, o partido único do regime" (PAULO, 2011, p. 111).

Assim, focando a análise nas cenas do Jornal Português em questão, podemos dizer que tanto a população portuguesa lato sensu quanto os apoiadores diretos do Estado Novo aglomeravam-se na praça para ouvir Salazar, formando um amálgama diante das câmeras do noticiário, cumprindo a função de público-ator (Figura 58). A pesquisadora também lembra que "Estes tipos de imagem conferem um cunho de 'espontaneidade' às manifestações, organizadas previamente pelos diversos organismos corporativos e controladas pelos elementos da repressão oficial” (PAULO, 2011, p. 112). 


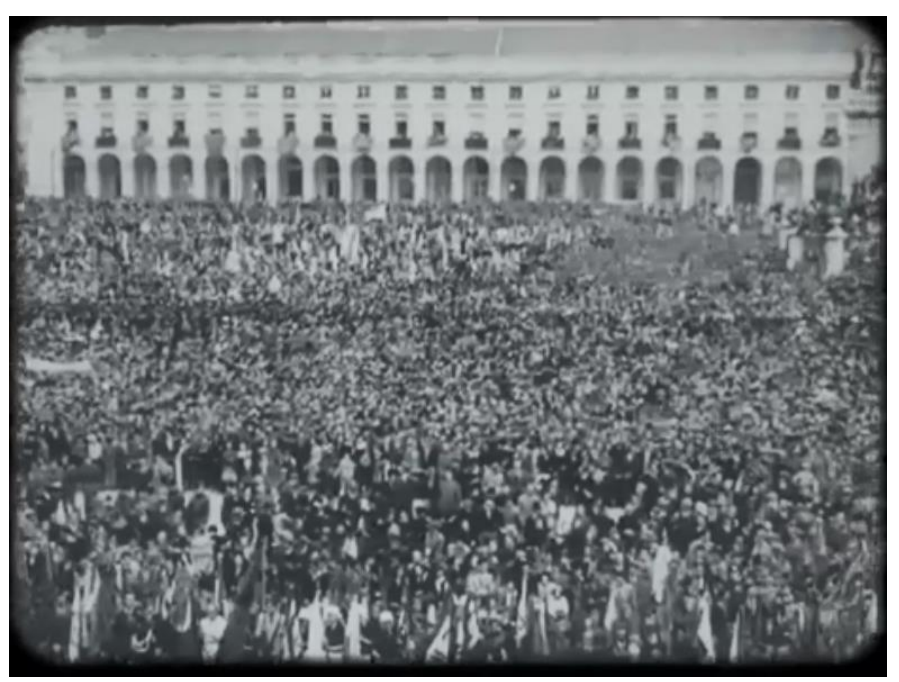

Figura 58: Multidão presente na manifestação em apoio a Carmona e Salazar: exemplo de "público-ator", composto pelo povo em si e por apoiadores engajados do regime.

Nota-se a intenção dos produtores da peça propagandística em captar o maior número de pessoas possível, pois isso reforçaria a ideia de apoio incondicional por parte da população. Dessa forma, a câmera se movimenta horizontalmente, em plano aberto, tanto para a direita quanto para a esquerda, sequiosa por captar um número elevado de indivíduos. Com relação à edição dessas imagens, Heloísa Paulo lembra que "Os variados cortes ajudam a manter a ideia de movimento, sendo, por vezes, necessários para a composição da mensagem e uma possível 'limpeza' de eventuais mensagens dissonantes” (PAULO, 2011, p. 111).

Outro aspecto que não pode deixar de ser considerado nestas imagens é a presença de várias embarcações no Rio Tejo (Figura 59). Além de exercerem a mesma função que o agrupamento de pessoas no tocante ao apoio integral construído pela propaganda, elas remetem ao passado marítimo português nos tempos áureos das explorações e conquistas de ultramar. Heloísa Paulo (2011) explica que

[...] a filmagem apresenta planos alternados onde podemos ver as imagens da multidão concentrada na praça e cena de barcos no Tejo, semelhantes às gravuras da época dos Descobrimentos. A evocação do passado aparece como pano de fundo para a manifestação do público no presente, reafirmando a ideia do regime como o recuperador das antigas glórias do País (PAULO, 2011, p. 112). 


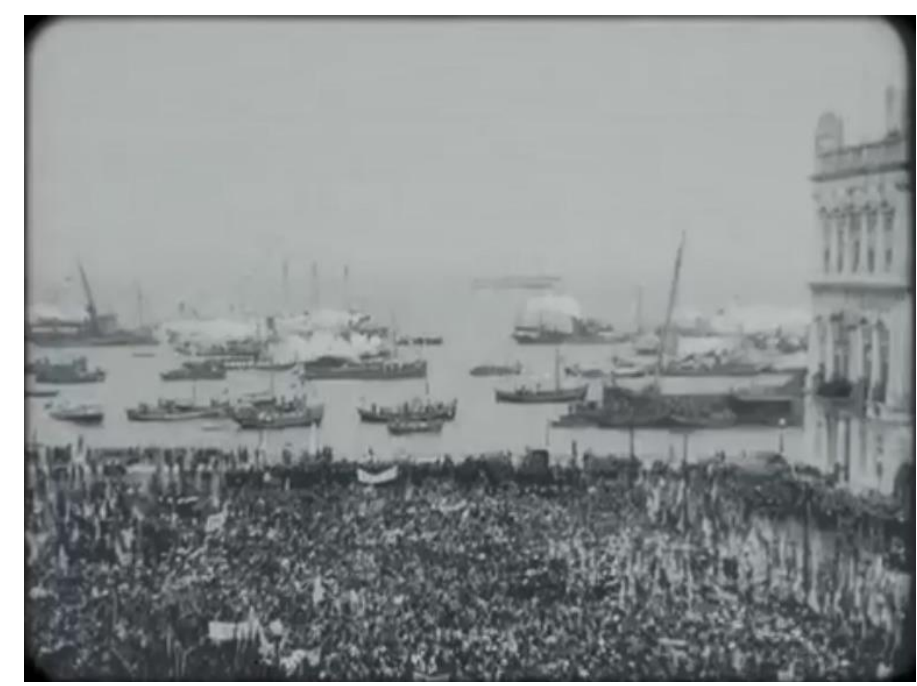

Figura 59: Enquadramento que privilegia a presença de embarcações no Rio Tejo. Além de reforçar o apoio popular ao regime por parte da multidão, esta imagem remete à época das grandes navegações.

Construído de forma a parecer que o povo se reuniu voluntariamente no Terreiro do Paço para agradecer ao ditador, Salazar inicia o seu pronunciamento demonstrando surpresa e constrangimento diante daquela atitude:

Homens e mulheres de Portugal. Não sei, decididamente, não sei como agradecer-vos esta manifestação tão carinhosa, tão sincera, tão desinteressada, mas tão pouco merecida [aclamação do povo]. Assim penso, e, no entanto, não evitei nem me eximi a este acto. Porquê? Era bem que vivêssemos juntos o momento de satisfação patriótica depois dos perigos a que todos estivemos sujeitos e nos horrores que muitos houveram de sofrer. Era bem que eu pudesse agradecer, como homem de governo carregado de responsabilidades, a vossa parte da tarefa, a parte maior de trabalho, de ordem, de disciplina, de sacrifício, durante os maus anos passados. Era bem que se pudesse ver, não à volta de um homem, de um governo, ou de um regime, mas dum princípio de independência, de fidelidade e honra nacional neste momento inolvidável. E me acompanheis num viva a Portugal. Viva Portugal! (FANTASIA LUSITANA, 2010, 57:14 - 58:40).

O excerto acima é bastante emblemático, pois evidencia alguns dos ideais do regime. Ao tomar a palavra, Salazar alega não saber como agradecer à população por aquela manifestação considerada carinhosa, sincera e desinteressada, procurando demonstrar acanhamento e não merecimento daquela homenagem. Entretanto, ele toma o seu lugar em frente ao microfone, aceitando o "carinho espontâneo" do povo, trazendo em mãos um discurso previamente redigido, o qual é lido para a população. O governante diz ter aceitado essa demonstração popular para proporcionar um "momento de satisfação patriótica", bem típico dos governos autoritários e nacionalistas daquela época. 
Além disso, Salazar agradece à população pela parte que lhes tocou durante os anos de guerra, como o trabalho, a ordem, a disciplina e o sacrifício, considerados por ele a parte mais importante. O ditador acaba por enfatizar o princípio de independência, fidelidade e honra nacional, que ultrapassam a figura de um homem, de um governo ou um regime. Antes, contudo, ele expressa que o seu cargo é "carregado de responsabilidades", num discurso ambíguo, que, ao mesmo tempo que justifica a sua presença como líder do país, transfere para a nação o papel mais importante, como se ele fosse o seu protetor. E, para não haver dúvidas de que o país estava acima da figura do Chefe da Nação, o ditador convoca a população a saudar Portugal com um viva (Figura 60).

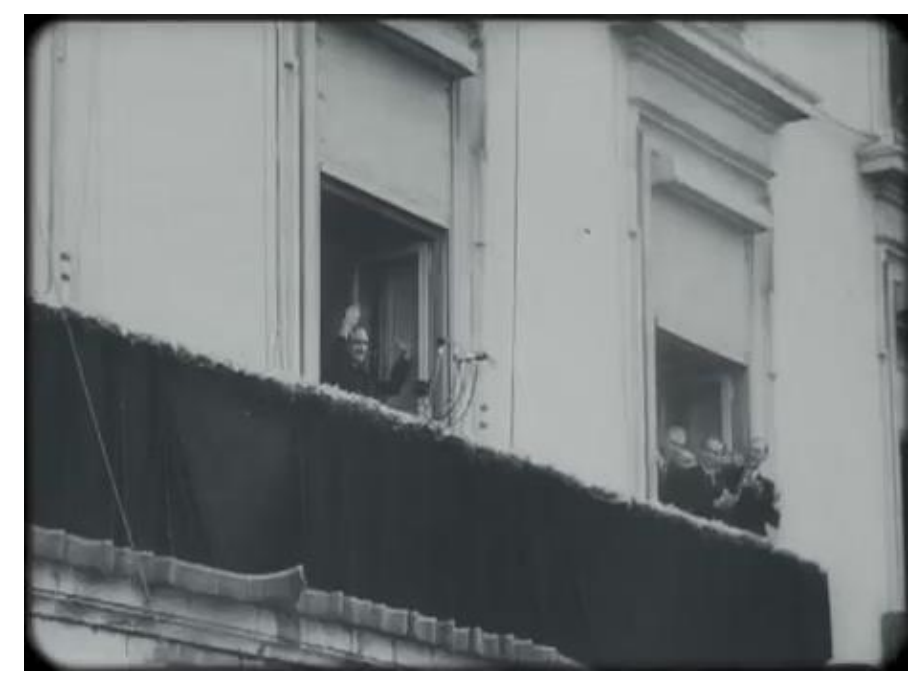

Figura 60: Momento após o término do discurso de Salazar, quando o ditador pede ao povo para saudar Portugal com um viva.

Heloísa Paulo lembra que

Este tipo de linguagem é repetido inúmeras vezes em diversos documentários oficiais, sendo comum não só nos que são voltados para a difusão da ideia da existência de um forte apoio popular ao regime, mas nos que buscam reafirmar a imagem de um Estado que se situa acima da sociedade, como uma espécie de seu «guardião» (PAULO, 2011, p. 112-113).

Se Salazar não exalta a si próprio através de seu discurso, o que seria considerado uma atitude reprovável, o mesmo não se aplica à locução daquela edição do Jornal Português. Após o término do discurso do ditador e a saudação ao país, o narrador informa que

A multidão aclamou longamente, interminavelmente, o homem que a poupou aos horrores dos bombardeamentos, da ocupação estrangeira, da destruição e da carência de tudo. Era bem Portugal agradecido que cantava, dando graças a Deus. Portugal, escrupulosamente e honrosamente neutro, que não teve o seu 
Dia V, teve o seu Dia S. O dia da paz portuguesa. O dia de Carmona e Salazar (FANTASIA LUSITANA, 2010, 58:44 - 59:17).

A construção narrativa do material propagandístico exalta a figura do Chefe da Nação, atribuindo a ele a função de protetor dos portugueses durante os anos difíceis da guerra, ou seja, o noticiário informa que Salazar foi o responsável por poupar a população de passar por bombardeios, ocupações estrangeiras, destruições e carência, tal como ocorrera à maioria das outras nações europeias. Em suma, o discurso constrói um Salazarherói, necessário e promotor da paz, quando, de fato, sabemos que Portugal era um país pobre, periférico, agrário, com um exército deficiente e incapaz de se proteger de eventuais ataques.

Através do uso da personificação, o locutor chama a multidão presente ao evento de "Portugal", estendendo, desse modo, o alcance daquela manifestação a todo o país. Assim, não era apenas o público reunido naquela praça quem cantava e dava graças a Deus, mas toda uma nação. A menção ao canto e ao Divino remetem aos louvores religiosos, aproximando Salazar da figura de Deus, uma vez que os agradecimentos da população eram destinados tanto a um quando a outro.

Semelhante aspecto pertinente no trecho em análise se refere ao uso dos advérbios. O locutor diz que o povo aclamou Salazar "longamente" e "interminavelmente", enfatizando a duração dos aplausos destinados ao ditador, em sinal de aprovação e veneração de sua figura. Além disso, os advérbios "escrupulosamente" e "honrosamente" são utilizados para modificar o adjetivo "neutro", que se refere ao status português durante os anos de guerra. A postura de neutralidade adotada pelo país ibérico é veiculada pelo noticiário com juízo de valor, isto é, se por um lado Portugal é considerado um país escrupuloso e honrado por não ter participado do conflito, essas qualidades estão ausentes nos países beligerantes, revelando, assim, o que não foi enunciado.

Por fim, as palavras finais do locutor revelam a astúcia do regime com o término do conflito. O Dia da Vitória na Europa (V-E Day), ocorrido em 08 de maio de 1945 após a rendição dos nazistas, simboliza o fim da guerra no continente. Contudo, a neutralidade portuguesa não permitiu que o país pudesse celebrar este acontecimento da mesma forma que as nações que tinham sofrido com as invasões e os ataques dos alemães. Dessa maneira, devido ao grande clima de esperança nascido em Portugal por setores que desejavam a queda de Salazar, o establishment vigente promove, num espaço de tempo muito curto, a manifestação em prol do regime, sufocando o desejo nascente. Na falta do 
Dia $V$, o documentário informa que Portugal teve o seu Dia $S$, simbolizando o dia da paz portuguesa, ou o dia de Carmona e Salazar (interessante notar que a letra C de Carmona é ignorada). A promoção dessa manifestação daria ao regime um fôlego que duraria ainda quase trinta anos.

\subsection{A síntese de um governo}

Passaremos em breve para a parte final de Fantasia Lusitana, que traz cenas da inauguração da estátua do Cristo Rei, ocorrida em 17 de maio de 1959, portanto, quatorze anos após o término da Grande Guerra na Europa. Contudo, antes de refletirmos sobre essas imagens, é necessário pontuar que entre as cenas referentes ao Dia $S$ e as que abordam a inauguração do Cristo Rei, há uma sequência de imagens, dos 59min19s aos 01h02min09s, que funcionam como elo entre os dois momentos, isto é, os anos de 1945 e de 1959. Esta conexão entre os dois períodos é bastante significativa pois acaba por exibir cenas do quotidiano português durante o regime salazarista, ou seja, Fantasia Lusitana logra fazer um resumo do que foi Portugal durante os longos anos do governo de Salazar através deste compêndio de imagens, que sintetizam a manutenção do Estado Novo.

As cenas exibidas são de um país agrário, retratando pessoas em trajos típicos em ambiente campesino: duas crianças no dorso de um jumento; carregadoras de água abastecendo ânforas e transportando-as, quer em muares, quer em suas cabeças; homens dirigindo-se ao campo, que, ao caminhar, levantam uma nuvem de poeira; jovens trabalhadores das vindimas a carregar cestos com uvas; agricultores que parecem plantar arroz em um terreno alagado; um rapaz conduzindo uma junta de bois em um carro apinhado de carga; um pastor cuidando de sua vara de porcos (Figura 61); mulheres transportando fardos em suas cabeças. 


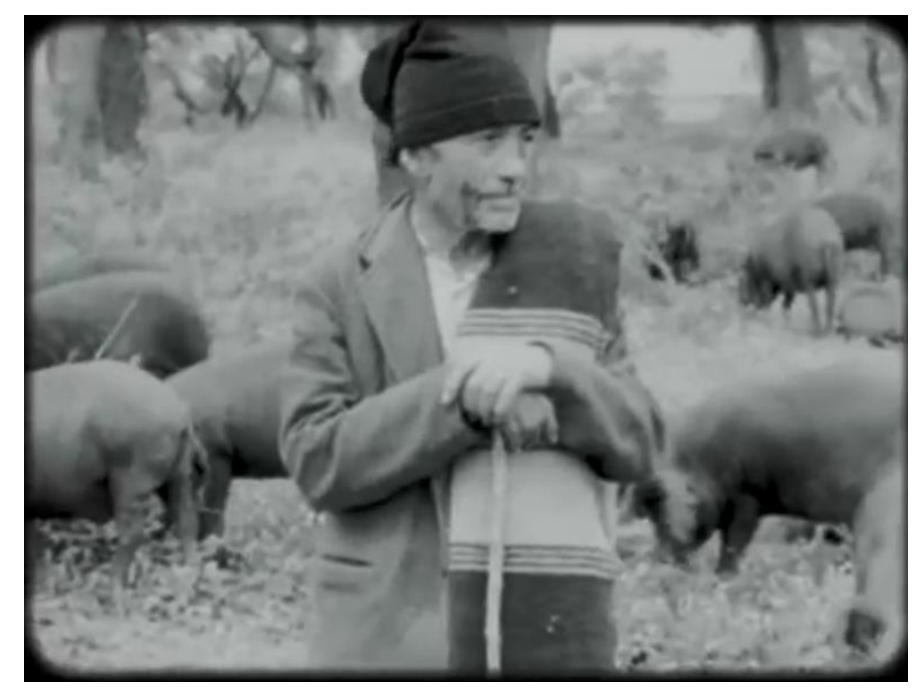

Figura 61: Pastor cuidando de uma vara de porcos.

É importante ressaltar que, no instante em que essa sequência de imagens começa a ser exibida, a montagem introduz o fado "Mãos Sujas", interpretado pela fadista Hermínia Silva. Esta canção, famosa da década de quarenta do século XX, estava em consonância com a mensagem que o Estado Novo primava em difundir acerca da importância e da valorização do trabalho. As imagens exibidas mostram o tipo de tarefa executada pelas pessoas as quais a canção homenageia. Dessa forma, enquanto o espectador vê as várias imagens de portugueses a desempenhar atividades árduas, ele ouve os seguintes versos: "Mãos sujas do suor, mãos negras do trabalho / Penhor da gente humilde, o seu melhor brasão / São quem maneja a serra e quem empunha o malho" (FANTASIA LUSITANA, 2010, 59:19 - 59:39).

A canção, que fala da "gente humilde" que usa ferramentas como a serra e o malho, cujas mãos estão sujas e suadas em razão do trabalho pesado e manual, é interrompida para dar voz a Salazar, que, mais uma vez, entra em cena inesperadamente com a sua "voz de Deus". Entretanto, antes de analisar o seu discurso, iremos continuar a análise da sequência de imagens.

Outras áreas pertinentes ao salazarismo são retratadas nas imagens que seguem: a religião (fiéis que pagam penitências ajoelhados ou engatinhando - Figura 62); eventos esportivos (desfiles em estádios, com foco para jovens exibindo medalhas); repressão policial (mulheres e crianças sendo ameaçadas com a coronha de uma espingarda (Figura 63) e homem ferido, acompanhado por possíveis investigadores policiais); jovens da Mocidade Portuguesa carregando arranjo de flores com o Brasão de Armas de Portugal; desfile de carnaval e de misses; mais trabalhadores a desempenhar tarefas árduas 
(catadoras de castanhas, pescadores, ceifadores de grãos); o futebol e a conquista do troféu; a pisa das uvas para a produção vinícola, acompanhada de música e dança.

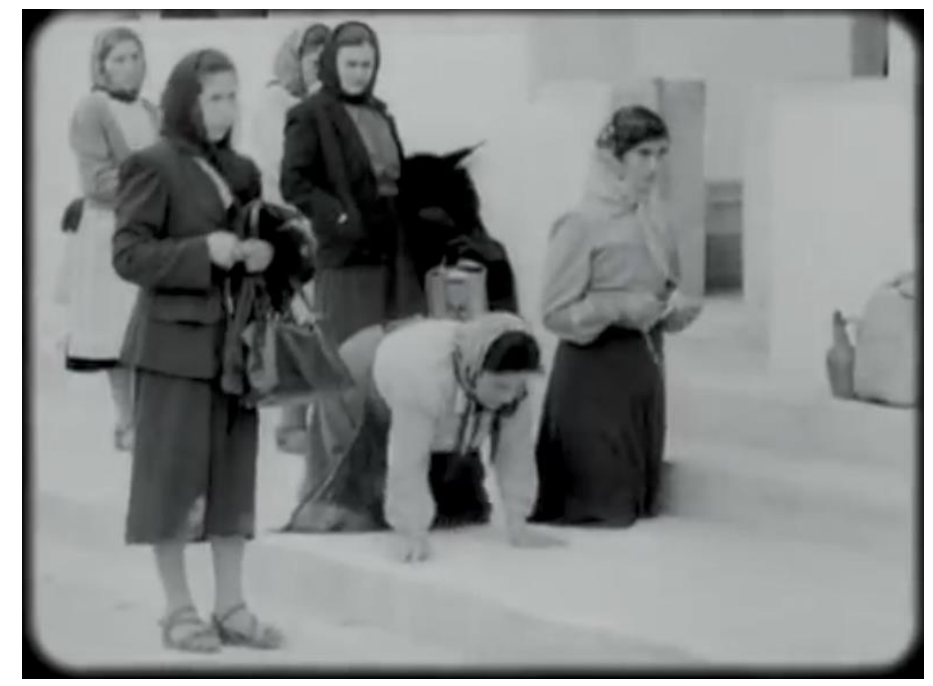

Figura 62: Fiéis se penitenciando em santuário religioso.

Essas imagens, que vinculam esses dois eventos, isto é, o Dia $S$ e a inauguração do Cristo Rei, estão intrinsicamente ligadas ao Estado Novo e podem ser resumidas em cinco categorias:

\section{$\left.1^{\circ}\right)$ Imagens que remetem ao mito da ruralidade:}

São as cenas mais abundantes neste trecho. Ela valorizam o cenário rural português, ou seja, "a terra, [...] [era vista] como a primeira e a principal fonte da riqueza possível, o caminho da ordem e da harmonia social, o tal berço das virtudes pátrias" (ROSAS, 2001, p. 1035), que se traduzem nas representações dos trabalhadores a lidar com as plantações, colheitas, o gado, a pesca, os mercados e a fabricação artesanal do vinho.

\section{$2^{\circ}$ ) Imagens que apontam para o mito da pobreza honrada:}

Destacamos as cenas que retratam a precariedade da população rural, com suas roupas simples, muitas vezes sujas devido ao labor com a terra, a magreza das pessoas, algumas descalças. Estas imagens dialogam com a característica de "um país essencial e incontornavelmente pobre devido ao seu destino rural” (ROSAS, 2001, p. 1035).

\section{$\left.3^{\circ}\right)$ Imagens que corroboram o mito da essência católica da identidade nacional:}

Referem-se aos trechos em que são retratadas pessoas rezando, muitas delas ajoelhadas, outras pagando penitências. Fernando Rosas (2001) irá definir esta 
característica como sendo "uma vocação religiosa, cristã e católica da nação portuguesa" (ROSAS, 2001, p. 1036). Destacamos neste excerto a presença de várias mulheres vestindo roupas pretas e cobrindo suas cabeças em sinal de luto. A maioria dessas pessoas traz o semblante triste, sombrio, cheio de dor.

\section{$4^{\circ}$ ) Imagens que estimulam o sentimento de alegria e portugalidade:}

Estão ligadas às passagens relacionadas às competições, aos jogos, aos desfiles, à exibição de medalhas, às danças típicas, ao carnaval e ao futebol. De uma forma ou de outra, seja por meio dos concursos, seja por meio dos esportes e outras distrações, o regime incute um sentimento de nacionalismo na população, com o fim de afastá-la dos problemas econômicos e sociais. "É neste equacionamento da identidade da nação que o Estado Novo legitima a sua acção de reaportuguesamento de Portugal" (GOMES, 20062007, p. 206).

\section{$5^{\circ}$ ) Imagens da repressão:}

Tratam-se de trechos (em menor quantidade, uma vez que não eram produzidos e nem divulgados pela propaganda) referentes à violência e à repressão policial contra certos setores da sociedade, principalmente contra aqueles que questionavam, desafiavam ou desobedeciam às ideologias do regime. Segundo o pesquisador Wagner Pereira, a polícia política "se encarregaria de tentar convencer os recalcitrantes, perseguir e reprimir os comunistas, socialistas, anarco-sindicalistas, republicanos, maçons, católicos progressistas e todos que fossem considerados 'inimigos da Nação"” (PEREIRA, 2008, p. 212-213).

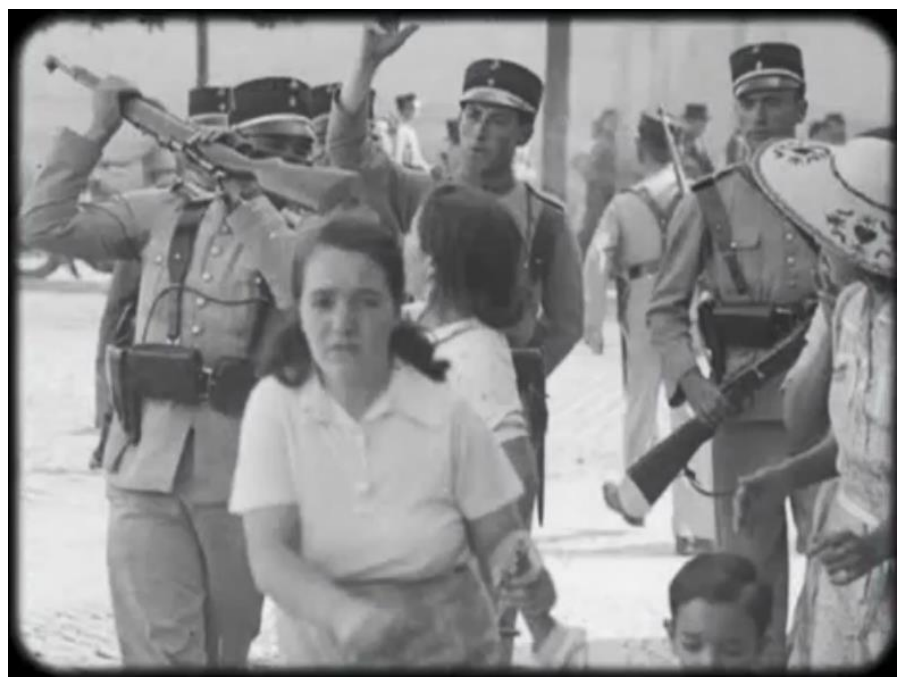

Figura 63: Cena de repressão policial contra mulheres e crianças ocorrida durante a ditadura de Salazar. 
A este trecho intermediário que conectam as imagens de 1945 às de 1959, a que chamamos de síntese do regime, Daniel Ribas (2014a) irá classificá-lo como uma

espécie de balanço: exibindo diversas imagens típicas da portugalidade - o
trabalho no campo, as peregrinações, jovens atletas, jogo de futebol, festas
populares, os pescadores, feiras agrícolas, etc. -, ouve-se, de novo, como um
eco, a voz de Salazar e da sua ideologia (RIBAS, 2014a, p. 282).

No que concerne ao discurso de Salazar, sobreposto ao fado de Hermínia Silva, ele é reproduzido em concomitância com as imagens já analisadas e versa sobe alguns temas recorrentes durante o Estado Novo. Não temos a intenção de pormenorizá-lo; queremos apenas destacar alguns dos pontos que estão profundamente ligados às imagens exibidas, já que tanto discurso quanto as imagens acabam por simbolizar o que foi o salazarismo. Em primeiro lugar, damos destaque para a definição que o ditador faz da nação:

[...] a Nação é para nós, sobretudo, uma entidade moral, que se formou através de séculos pelo trabalho e solidariedade das sucessivas gerações, ligadas por afinidades de sangue e de espírito, e a que nada repugna crer esteja atribuída no plano providencial uma missão específica no conjunto humano. (FANTASIA LUSITANA, 2010, 59:46 - 01:00:08).

O excerto acima explicita a construção ideológica da Nação como sendo uma instituição moral que une as gerações através do "trabalho, do sangue e do espírito". Não por acaso, as imagens propostas durante a leitura de Salazar retratam pessoas executando tarefas braçais e cansativas, inclusive crianças e idosos. De certa forma, esses trabalhadores são a representação dessas sucessivas gerações de trabalhadores anônimos que têm operado no decorrer dos vários séculos, desde a fundação de Portugal. Além disso, Salazar atribui à Nação uma missão providencial, levando a crer que Deus tem um plano para Portugal, e ele, Salazar, estava ali para que esse plano se cumprisse.

É então que o ditador irá reforçar a ideia da abnegação que os portugueses devem ter em nome da Nação: "Só esse peso dos sacrifícios sem conta, da cooperação de esforços, da identidade de origem, só esse património colectivo, só essa comunhão espiritual, podem moralmente alicerçar o dever de servi-la e dar a vida por ela" (FANTASIA LUSITANA, 2010, 01:00:09 - 01:00:26). O ditador coloca a Nação acima dos interesses individuais dos portugueses ao mesmo tempo em que oferece um sentimento de pertencimento àquela sociedade, através da "identidade de origem", do "património colectivo" e da "comunhão espiritual", isto é, características e valores supostamente compartilhados por toda aquela gente. Segundo Salazar, as privações 
infligidas pela Nação a seu povo são soberanas, a ponto de os indivíduos terem que a servir, dando a própria vida por ela, se necessário.

Salazar então lançará mão de um dos lemas mais famosos do Estado Novo, isto é, Tudo pela Nação, nada contra a Nação, para lembrar que ainda há pessoas que se deixam influenciar por outros ideais. Para o ditador, "O comunismo faz a defesa, mais que a defesa, a apologia do antinacionalismo, mas incoerentemente subordina os interesses da comunidade nacional aos de uma soberania estrangeira que lhes é hostil" (FANTASIA LUSITANA, 2010, 01:01:00 - 01:01:15). Ao construir a ideia da Nação portuguesa, o ditador ataca os ideais comunistas, que, segundo ele, estariam subordinados a um poder estrangeiro contrário à Pátria.

Dessa forma, com o intuito de arrematar o seu posicionamento perante a construção da ideia de Nação, ele prossegue:

Este doce país que é Portugal, pequeno na Europa, grande e dilatado nos outros
continentes, como árvore que alimentando-se da seiva lusitana espalhasse
longos ramos a sois diferentes e a sua sombra abrigasse as populações mais
diversas, todas igualmente portuguesas, este pequeno país, não pode, no nono
século da sua história, duvidar da sua realidade de Nação. Esta realidade em
que englobamos a independência, a unidade orgânica e a missão civilizadora,
é um pressuposto ou ponto de partida a que foge toda a discussão. E daqui este
corolário: quem não é patriota, não pode ser considerado português
(FANTASIA LUSITANA, 2010, 01:01:16-01:02:07).

$\mathrm{O}$ trecho acima traz à baila vários conceitos que foram resgatados, adaptados ou construídos durante o governo de Salazar. Em primeiro lugar, ele delimita o país, não o restringindo ao território ibérico, mas incorporando-o nas extensões territoriais africanas e asiáticas que estavam sob a administração portuguesa de então. Portugal é chamado de "doce país" pelo ditador, que defende a ideia de um território português ao mesmo tempo continental e ultramarino, visto, no momento da enunciação do discurso, isto é, no pósguerra, como parte integrante do país. Salazar reconhece a diversidade étnica e cultural dos seus habitantes, mas, utilizando a metáfora da árvore, faz com que todos se alimentem da mesma "seiva lusitana".

Em seguida, o Presidente do Conselho reforça a ideia da construção da Nação, elaborada no decorrer de seu discurso. Ele lembra que Portugal está no seu nono século de existência, ou seja, trata-se de um país antigo, com muitos anos de história, e, portanto, não pode se desviar dos valores nacionais, isto é, "a independência, a unidade orgânica e a missão civilizadora", que, segundo ele, são indiscutíveis. 
Por fim, com o propósito de sintetizar o pensamento que vinha sendo desenvolvido, Salazar lança mão do corolário: "quem não é patriota não pode ser considerado português”. Esta máxima resume a inquestionabilidade em relação à Nação, aproximando-se de um pensamento ufanista brasileiro utilizado durante a ditadura militar: "Brasil, ame-o ou deixe-o". Esses lemas têm a intenção de cobrar um posicionamento da população, oferecendo apenas duas opções. O binarismo imposto possui uma carga emocional forte, principalmente sob regimes que investem no desenvolvimento do sentimento da Nação, isto é, do pertencimento a um grupo.

Esta sequência que une os dois contextos portugueses, isto é, o evento de 1945 e o de 1959, parece ter sido introduzida pela montagem a fim de evidenciar o resultado da perspicácia do regime. Ao promover o Dia $S$, Salazar evita uma possível queda já que, com o fim da guerra e a consequente fundação da Organização das Nações Unidas, a Europa e os outros continentes exigiam um mundo mais democrático. É o que pontua Ricardo Braga:

\footnotetext{
Com o fim da Segunda Guerra Mundial e, consequentemente, com as democracias a vencerem as ditaduras, o futuro do regime estava em causa, havia que redefinir o seu posicionamento externo. Salazar pretendia rentabilizar politicamente a neutralidade colaborante, utilizando-a como contrapartida do apoio dos Aliados à salvaguarda do salazarismo (BRAGA, 2005, p. 157-158).
}

Assim, conseguir resistir às pressões estrangeiras fez com que o ditador lograsse estender o regime por décadas ainda, mesmo depois de sua morte. Dessa forma, este trecho intermediário pode ser entendido como uma síntese do que foi Portugal durante o governo de Salazar, remetendo ao atraso e ao provincialismo nos quais o país se manteve durante a era salazarista.

\subsection{A inauguração do Cristo Rei}

Partimos para os momentos finais de Fantasia Lusitana que versam sobre a inauguração da estátua do Cristo Rei, ocorrida em 17 de maio de 1959, na margem sul do Rio Tejo, em Almada. Essas são as únicas imagens usadas no documentário que foram produzidas originalmente a cores, transcorrendo em pouco menos de dois minutos. Embora o período retratado deixe de corresponder aos anos referentes ao conflito bélico internacional, fugindo ao recorte principal da película, a inauguração desse monumento funciona como desfecho do que foi o Dia S. Referentemente a esta temática, "O filme 
termina com o ato público de gratidão divina, pelo facto de Portugal ter escapado da guerra, mostrando a inauguração, em 1959, do monumento do Cristo-Rei, em Lisboa, uma homenagem ao fim da guerra e à neutralidade do país" (MACEDO, BASTOS e CABECINHAS, 2016, p. 46-47).

É notória a influência da religião no que concerne a inauguração desta estátua, inspirada no Cristo Redentor do Rio de Janeiro. Uma vez que a justificativa para que este local sagrado fosse criado tenha sido o agradecimento (A Deus? A Salazar?) pelo fato de Portugal ter saído incólume da guerra, observamos que ocorre uma mescla entre assuntos de Estado e Igreja.

As imagens que são apresentadas em Fantasia Lusitana, bem como a alocução, entonação e escolha lexical que descrevem este acontecimento, contribuem para que se crie este efeito. De acordo com Daniel Ribas, "Há, nessa sequência, uma confusão propositada entre nação e religião: como se Portugal fosse protegido por Deus; é também o cúmulo público da providencialidade de Salazar, reiterando a sua missão salvadora do povo português" (RIBAS, 2014a, p. 282).

Esta aproximação com a religião está fundamentada no mito da essência católica da identidade nacional, conforme temos demonstrado nesta dissertação. Sendo assim, a preocupação do regime em transmitir os valores religiosos aos portugueses começava já na infância, sendo difundido no ambiente escolar. Martinho explica que "A despeito da natureza formalmente laica do Estado Novo, o ensino religioso foi reintroduzido nas escolas oficiais e influenciou decisivamente os curricula, principalmente do ensino primário" (MARTINHO, 2007, p. 25), o que, de certa forma, evidencia o apoio mútuo entre a Nação e a Igreja Católica Portuguesa na formação da população. Veremos agora de que forma é construída essa dubiedade a partir da recuperação das imagens e da narração original.

Assim como na passagem referente ao Dia $S$, a multidão exerce um papel fundamental na construção narrativa propagandística, uma vez que ela atua como comprovação do apoio popular ao regime. Além disso, a presença da população também invoca o apelo religioso característico ao evento, ou seja, a inauguração da estátua símbolo do Cristianismo. Dessa forma, aos 01h02min13s, vemos uma tomada que retrata o público presente naquela inauguração, ressaltando, logo na primeira fileira, representantes da imprensa, bem como a figura de uma religiosa, possivelmente uma 
madre, a julgar pelos seus paramentos, que desfrutam um local de destaque (Figura 64). Tem-se a impressão de que a multidão se estende até a linha do horizonte, perdendo-se de vista, o que reforça a ideia do apoio maciço por parte do povo.

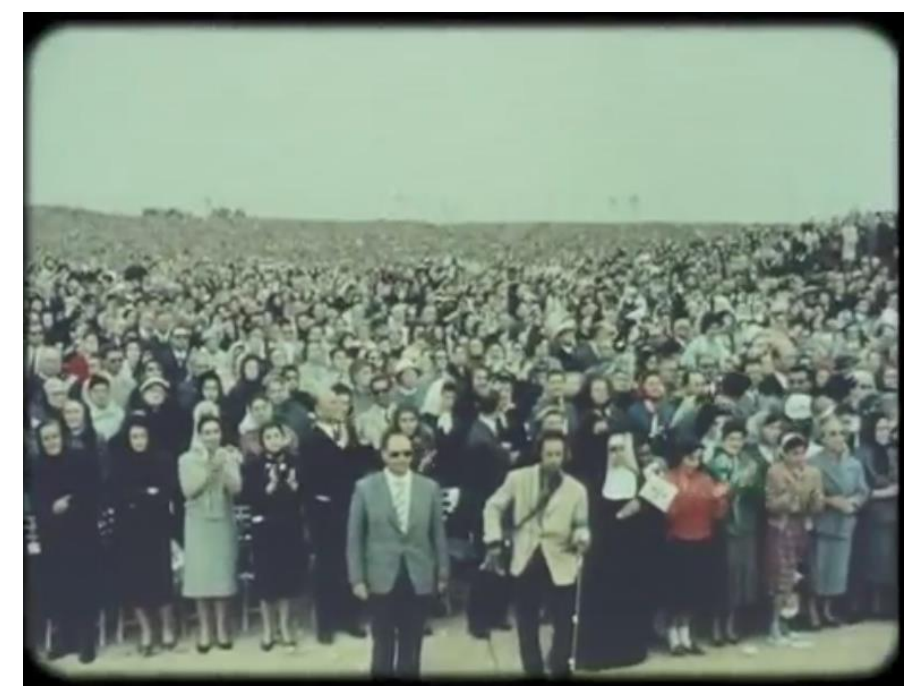

Figura 64: Público presente à inauguração do Cristo Rei em 17 de maio de 1959.

No que concerne à narrativa do evento, a alocução informa que "Juntaram-se centenas de milhares de pessoas, que à chegada do Chefe do Estado, como já o tinham feito ao Presidente do Conselho, irromperam em aplausos e aclamações" (FANTASIA LUSITANA, 2010, (01:02:11 - 01:02:20). Inicialmente, é oportuno ressaltar a ênfase dada à quantidade de pessoas ali reunidas, o que reforça o argumento referente à construção da ideia de apoio irrestrito ao governo por parte da população.

Em seguida, notamos a veneração das imagens tanto do Presidente do Conselho, isto é, Salazar, quanto do Presidente da República, que, naquela altura, era o Almirante Américo Thomaz. É importante pontuar que, não obstante a multidão estivesse ali reunida para a inauguração da estátua do Cristo Rei, a propaganda estatal realça os aplausos e aclamações direcionadas aos líderes da Nação, reforçando a aura de idolatria para com eles. À chegada de Américo Thomaz, vemo-lo cumprimentando um cardeal, ambos rodeados por religiosos, bem como por fotógrafos (Figura 65). 


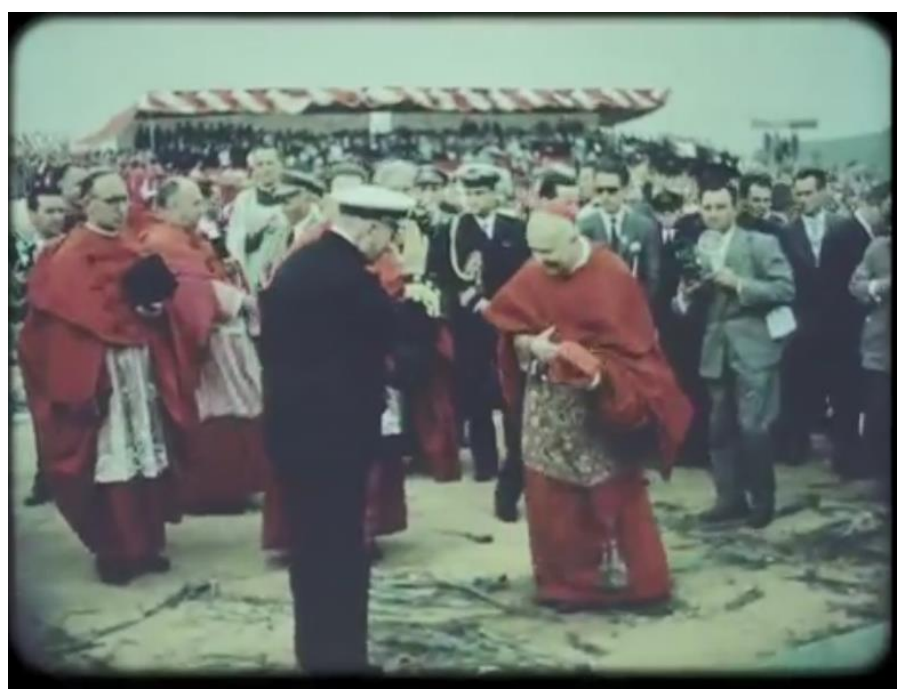

Figura 65: O Presidente da República Américo Thomaz e um cardeal se saúdam na ocasião da inauguração do Cristo Rei.

Se por um lado as imagens exibem o Presidente da República em plano geral, juntamente com outras pessoas, o mesmo não ocorre com o Presidente do Conselho. Dada a sua importância, Salazar é retratado, primeiramente ao lado de seus ministros, em tribuna adrede preparada, para, em seguida, ser enquadrado em primeiro plano (Figura 66), o que lhe confere notoriedade e distinção.

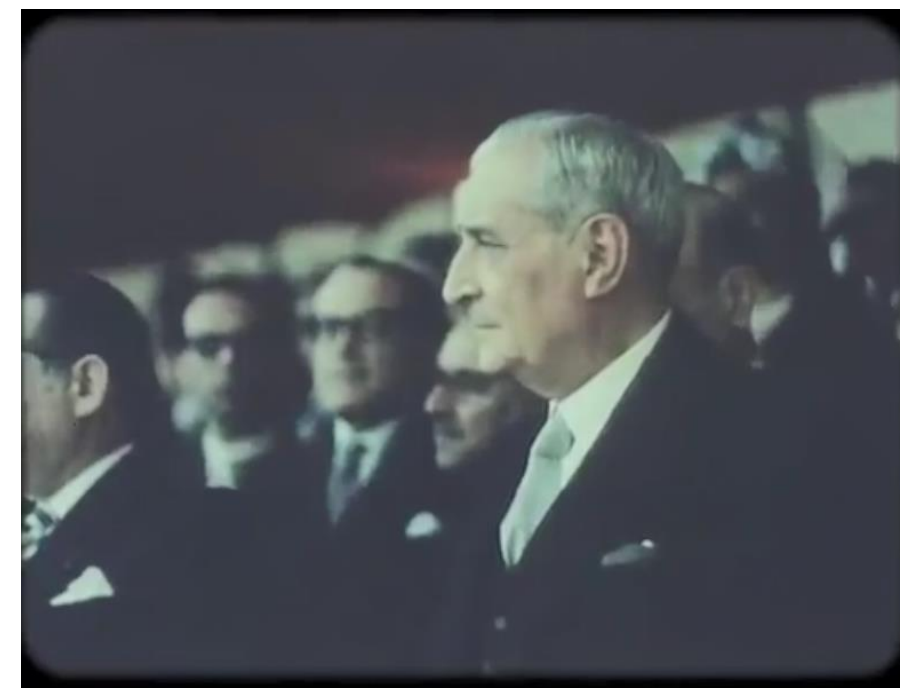

Figura 66: Plano que destaca a figura de Salazar durante a inauguração da estátua do Cristo Rei.

Enquanto as cenas do ditador são exibidas, não ocorre alocução; mantém-se apenas a música suave que servia de pano de fundo para a voz do locutor. Este expediente faz com que o espectador não precise prestar atenção no que é dito, permitindo que, durante seis segundos, ele apenas "contemple" a figura do Presidente do Conselho, um Salazar que, no auge dos seus setenta anos, se encontra bem mais envelhecido se comparado às suas outras imagens no decorrer de Fantasia Lusitana. 
Até então, percebemos que ocorre a construção de um ar de veneração para com essas duas figuras políticas, com destaque para Salazar, colocando-as em pé de igualdade com os símbolos religiosos, receptores do mesmo tipo de adoração. Em seguida, o locutor passará a abordar a inauguração do monumento em si: "Pouco depois, uma revoada de seis mil pombos e uma chuva de milhões de pétalas lançadas do topo do pedestal anunciaram o momento da benção do monumento" (FANTASIA LUSITANA, 2010, 01:02:26-01:02:36).

A utilização de pombos e de pétalas como arautos das bênçãos ao monumento é bastante significativa, pois, num sentido geral, simbolizam a paz e a esperança. Segundo a tradição religiosa hebraico-cristã, foi uma dessas aves que Noé enviou durante o dilúvio para descobrir se havia terra firme, tendo ela retornado com um ramo de oliveira, simbolizando a esperança de recomeço para a humanidade. Dessa forma, a pomba é vista como mensageira de boas novas. Outra representação para essa ave se origina na passagem do batismo de Jesus. Segundo o dogma cristão, quando Jesus foi batizado, o Espírito Santo desceu sobre ele em forma de pomba. Logo, a escolha das pombas e das pétalas para anunciarem as bênçãos ao monumento não é fortuita, pois reforçam a solenidade e a suntuosidade desejadas para a ocasião, além de fortalecerem a aura religiosa.

A narração propagandística atribui características humanas à estátua, pois, "Lá no alto, o Cristo Rei, de braços abertos, parecia receber as súplicas do povo" (FANTASIA LUSITANA, 2010, 01:02:36 - 01:02:41). Esse "alto" a que se refere o locutor é, inicialmente, ambíguo, pois pode tanto significar a altura onde fora colocada a estátua como o "paraíso", onde, segundo a tradição religiosa, habitaria o Cristo. Entretanto, ao mencionar os "braços abertos", constatamos se tratar da estátua propriamente dita, apesar da impressão de que ela estaria "recebendo" as súplicas do povo.

A montagem original foi feita de modo a construir uma interação entre o Cristo Rei e a população. A primeira cena mostra a estátua em contra-plongée, como se ela estivesse olhando para o povo (Figura 67). 


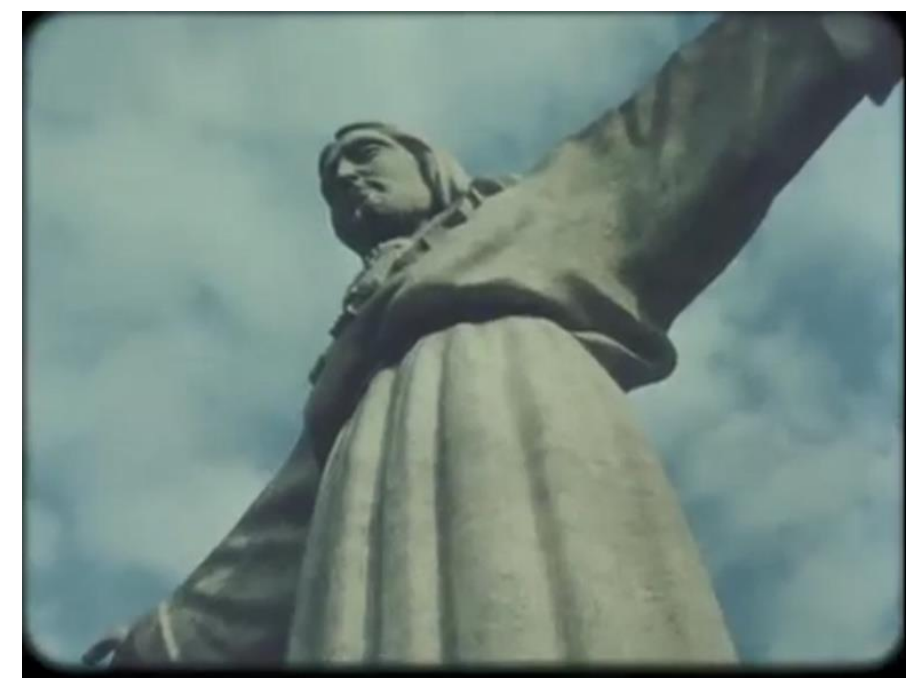

Figura 67: Enquadramento em contra-plongée da estátua do Cristo Rei.

Em seguida, o espectador vê, em plongée, a multidão em "baixo", como se fosse massa indistinta (Figura 68).

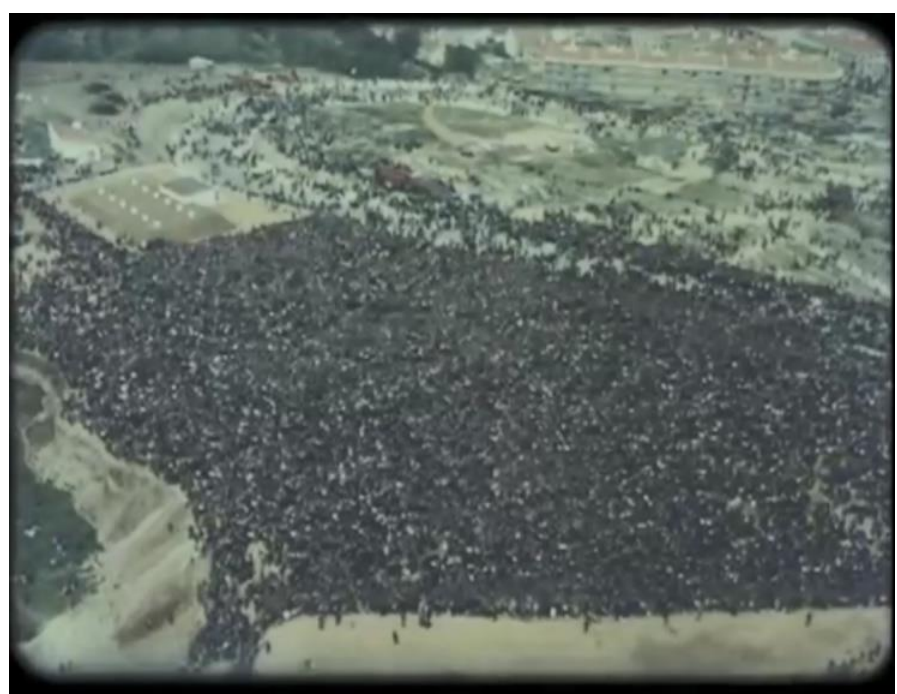

Figura 68: Enquadramento em plongée da multidão que esteve presente na inauguração do Cristo Rei.

Se faz clara a oposição entre "alto" e "baixo", ou entre "superior" e "inferior". O povo é retratado como massa submissa, perante a grandiosidade da imagem religiosa, que, de certa forma, se estende à esfera política, visto que, conforme temos discutido, há uma fusão entre os discursos político e religioso neste material.

As cenas exibidas são agora de um cardeal a gesticular, diante de diversos microfones, enquanto discursa. Não ouvimos suas palavras, apenas o narrador que, empolando a sua voz, procura imitar a entonação da figura religiosa: "Portugal foi ouvido. O voto está cumprido', afirma a Sua Iminência na sua vibrante alocução" 
(FANTASIA LUSITANA, 2010, 01:02:44 - 01:02:45). As palavras atribuídas ao cardeal se referem ao cumprimento da promessa pelo fato de Portugal sair ileso da guerra, ou seja, a construção e inauguração da estátua do símbolo máximo do Cristianismo.

Porém, um acontecimento que poderia passar completamente ignorado, dada a trivialidade diante da quantidade de pombos que foram soltos naquele evento, acaba ganhando proeminência. O noticiário de 1959 chama a atenção para o fato de uma ave ter pousado ao lado de Américo Thomaz: "Uma das pombas brancas, que se encontravam refugiadas entre rosas do andor da Virgem de Fátima, levantou voo e foi poisar na tribuna presidencial” (FANTASIA LUSITANA, 2010, 01:02:54 - 01:03:02).

Vários são os elementos simbólicos retratados neste pequeno excerto. A começar, dentre os seis mil pombos que foram libertados naquela ocasião, a ave que pousou próxima ao Presidente da República era branca. Não sabemos se a totalidades de animais era dessa cor, porém, ela remete à ideia da paz, da mesma forma que a bandeira branca está associada à rendição, ou seja, à não beligerância. Aquele monumento foi erguido justamente para celebrar a paz portuguesa durante os anos da Grande Guerra, logo, a presença da pomba branca estava em consonância com a ocasião. Outra representação dessa cor se refere à pureza, à castidade ou à inocência, isto é, qualidades morais apregoadas tanto pelo Estado Novo quando pela Igreja Católica.

Depois, é interessante notar que a referida ave se encontrava refugiada antes de escolher pousar na tribuna do Presidente. O seu esconderijo era "entre as rosas do andor da Virgem de Fátima", isto é, mais uma referência religiosa importante para Portugal, considerando se tratar da padroeira nacional. Entretanto, o trajeto escolhido pela pomba é assaz significativo, uma vez que ela parte do território religioso (Padroeira de Portugal) e tem como destino o território político-administrativo (Presidente de Portugal).

As imagens mostram um Américo Thomaz ajoelhado, circunspecto, em oração, enquanto a pombinha branca caminha despreocupadamente no tablado onde está a tribuna. Thomaz parece não notar a presença do animal tão próximo a ele, dado que ele parece estar concentrado na liturgia religiosa (Figura 69). Além da ave, há também flores brancas na tribuna do Presidente, que se encontravam ali antes da chegada do animal, ou seja, o Almirante já estava sendo representado pela simbologia por trás dessa cor. 


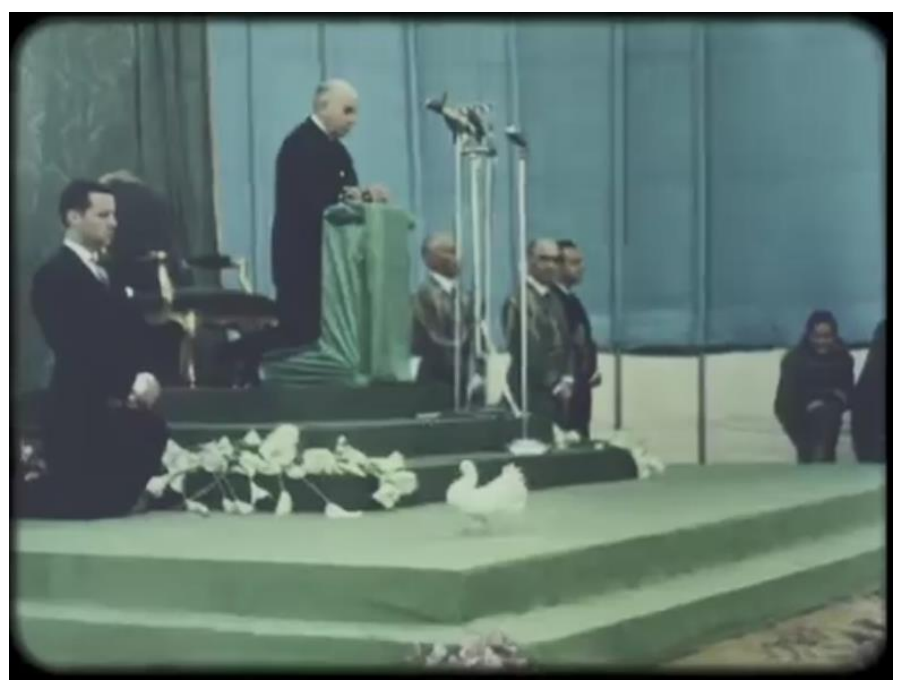

Figura 69: Pomba branca caminha na tribuna de Américo Thomaz durante as liturgias católicas na inauguração do Cristo Rei em 1959.

Dessa forma, assim como Jesus Cristo teria recebido o Espírito Santo em forma de pomba durante o seu batismo (segundo as anotações bíblicas), Américo Thomaz, símbolo da nação portuguesa na função decorativa de Presidente da República, também "recebe" a visita do mesmo animal. Por analogia, ao decidir retratar este acontecimento comum e esperado diante da quantidade de aves para ali trazidas, a propaganda salazarista acaba por comparar a figura de Jesus Cristo com a do Presidente da República, uma vez que a associação da imagem da pomba branca com o Espírito Santo era conhecida pela maioria dos presentes, por serem católicos. Como o Presidente da República simboliza a Nação, logo, podemos entender que o discurso proposto pela propaganda estatal poderia ser o de que Portugal seria o país eleito por Deus, discurso esse propagado durante várias épocas da historiografia portuguesa.

Este amálgama entre Estado e Igreja acaba aparecendo na fala do locutor a respeito do público presente, uma vez que "A multidão, agitando pequenas bandeiras com a Cruz de Cristo, dá largas ao seu regozijo e canta em coro impressionante o Hino Nacional" (FANTASIA LUSITANA, 2010, 01:03:04 - 01:03:12). É pertinente pontuar que o povo, embora carregue e movimente uma insígnia religiosa, canta o Hino Nacional, símbolo da Nação por excelência. Em suma, embora Portugal tenha status de país laico, parece não haver uma fronteira definida entre Estado e Religião.

Por fim, as derradeiras cenas de Fantasia Lusitana são imagens aéreas captadas provavelmente a partir de um helicóptero, que gira em torno à estátua (Figura 70) enquanto o locutor enuncia: 
Lá no alto, a imagem de Cristo Rei, grato por tão grande manifestação de fé, dir-se-ia que a todos queria envolver num mesmo abraço de proteção e generosidade para Portugal inteiro, para todos os portugueses espalhados pelo mundo. Um abraço que é benção, perene solicitude, atenção vigilante, defesa invencível, penhor da continuidade da pátria, certeza da sua imortalidade. Olhando o Tejo, donde sua cruz ganhou o mundo, Cristo há de continuar a apontar a Portugal a rota das glórias e da vitória (FANTASIA LUSITANA, 2010, 01:03:13-01:03:45).

Nesta construção narrativa propagandística tem-se a intenção de transferir qualidades humanas à estátua do Cristo Rei, como o sentimento de gratidão e o desejo de envolver todos os presentes em um abraço. De fato, este abraço é direcionado a "Portugal inteiro", bem como aos portugueses que se encontram no exterior. Vemos claramente, nessas palavras, o reforço da imagem dos portugueses como povo eleito pelo Cristo para prosperar na Terra, conforme temos discutido nesta dissertação.

Referentemente ao abraço do Cristo Rei aos portugueses, ele é definido como:

- Benção;

- Perene solicitude;

- Atenção vigilante;

- Defesa invencível;

- Penhor da continuidade da pátria;

- Certeza da sua imortalidade.

Tais definições estão ligadas ao campo semântico, quer da religião, quer da estrutura governamental. As duas primeiras pertencem claramente ao âmbito religioso e moral, ao passo que as restantes se aproximam da ideologia do Estado Novo, pois abordam temas como a vigilância e a defesa, assuntos explorados durante o regime salazarista. Ademais, as duas últimas se referem à continuidade e a imortalidade de Portugal. 


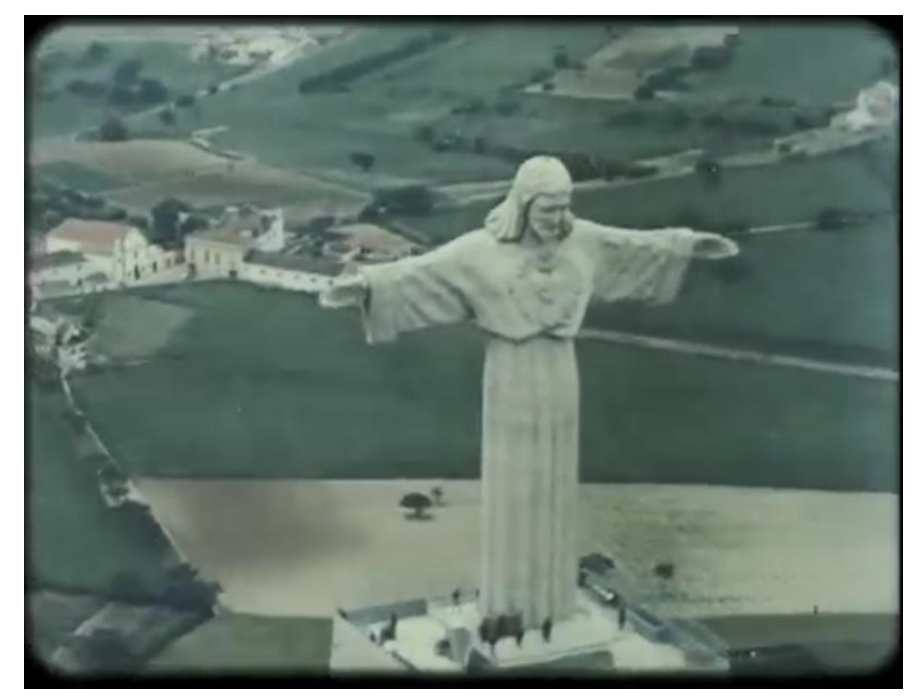

Figura 70: Imagem aérea da estátua do Cristo Rei nos momentos finais de Fantasia Lusitana.

Para não restar dúvidas a respeito deste vaticínio acerca do cumprimento de Portugal, o trecho termina com referência ao Rio Tejo, de onde saíam as naus com a Cruz do Cristo para "ganhar o mundo" nos tempos gloriosos da expansão marítima. Entretanto, faz-se nítido que esta profecia ainda não se cumpriu, pois, o locutor diz que o Cristo seguirá apontando à Nação Portuguesa a "rota das glórias e das vitórias", sugerindo que o país ainda não redescobriu este caminho.

Por fim, a canção Lisboa, não sejas francesa, cantada por Amália Rodrigues, surge na tela, e os créditos finais do documentário começam a subir. Esta canção é bastante apropriada para finalizar o documentário de João Canijo, pois tem um teor nacionalista, assim como o Estado Novo. Nela, a cantora aconselha Lisboa a não namorar os franceses, pois, caso contrário, “com toda certeza, não vais ser feliz”. Além disso, a canção assevera que Lisboa é portuguesa e é "só pra nós”, ou seja, só para os portugueses, lembrando a exclusividade e a eleição deste povo. 


\section{CONCLUSÃO}

Faltando oito anos para o centenário do golpe militar de 1926 que viria a instaurar o Estado Novo e, passados quarenta e quatro anos desde a Revolução dos Cravos, o salazarismo continua sendo uma ferida não totalmente cicatrizada na sociedade portuguesa. Isso se deve porque os desmandos ocorridos durante o longo período ditatorial não foram totalmente expurgados, demandando necessária reflexão crítica a esse respeito. Não apenas houve uma alargada política de redução de penas, perdão e anistia para com os membros do governo ditatorial nos anos iniciais de democratização, como também grande parte dos mitos difundidos pela propaganda salazarista ecoam até hoje.

Pesquisas efetuadas por Filipa Raimundo revelam que as sentenças emitidas pelos tribunais instaurados após o 25 de abril a fim de julgar os abusos praticados pelos braços do governo autoritário, como a polícia política, foram bastante amenas:

Segundo dados elaborados pela Comissão de Extinção da PIDE/DGS, foram
enviados para julgamento 2.667 processos, relativos a pessoal dirigente,
pessoal técnico e colaboradores [...]. De acordo com as estatísticas elaboradas
pela comissão, cerca de $68 \%$ dos indivíduos foram condenados a penas entre
um e seis meses de prisão maior. Contudo, a consulta dos processos, assim
como dos recursos interpostos junto do Supremo Tribunal Militar, revela dois
aspectos que alteram substancialmente essas conclusões: em primeiro lugar, a
todas essas sentenças foi descontado o período de prisão preventiva sofrida -
[...] cerca de 20 meses [...]; em segundo lugar, os tribunais fizeram
frequentemente uso de dois perdões de 90 dias, previstos pelos Decretos-lei n ${ }^{\circ}$
$729 / 75$, de 22 de dezembro e ${ }^{\circ} 825 / 76$, de 16 de novembro. Para além disso,
o $1^{\circ}$ TMT de Lisboa decidiu com frequência que [...] iria perdoar metade da
pena que deveria ser aplicada, segundo a Lei $8 / 75$, recorrendo ao Decreto-lei
$n^{\circ} 271 / 74$, de 21 de junho (RAIMUNDO, 2013, p. 119-120).

Além desse abrandamento, vemos, na figura do então Primeiro Ministro Mário Soares, do Partido Socialista, o mesmo tipo de discurso:

[...] o jornal Página Um (28 de abril de 1977) fez referência a uma entrevista de Mário Soares a um periódico francês, na qual o então primeiro-ministro e reconhecido antifascista se teria revelado favorável a uma lei de anistia que permitisse perdoar os crimes da ditadura e seguir em frente com a consolidação da democracia (RAIMUNDO, 2013, p. 122).

Podemos pensar que esse tipo de atenuação dos vereditos relacionados aos julgamentos das transgressões praticadas durante o período ditatorial tenha contribuído com a distorção ou o apagamento parcial da memória do que foram esses quarenta e oito anos de governo autoritário. 
Quanto à sobrevivência dos mitos apregoados pela propaganda salazarista já durante o período democrático, João Canijo afirma que um fator preponderante para que ele produzisse Fantasia Lusitana foi o fato de um professor de seu filho, um jovem nascido após o 25 de abril, crer e difundir em suas aulas um dos mitos criados durante o Estado Novo:

O professor do liceu do meu filho tinha 30 anos mas ainda lhe dizia que Salazar
foi muito bom porque impediu que Portugal entrasse na guerra. Isso foi uma
das razões determinantes para eu aceitar fazer este filme, aliás. Claro que o
meu filho, que tinha 14 anos, já sabia que não tinha sido assim, mas o professor
de 30 acreditava que sim. E que havia mais segurança [naquela altura]
(CÂMARA, 2010).

Canijo também atribui essa falta de pensamento crítico a respeito do passado salazarista à educação deficitária portuguesa, que segundo ele, foi e ainda é um problema. É o que revela em entrevista a Luís Leal Miranda:

Miranda: O que é que quer provar com este filme?

Canijo: Não quero provar nada. A ideia é apenas mostrar como as coisas eram. E quem tiver olhinhos vê que a herança ainda cá está e o nosso país não mudou assim tanto. Há uma coisa no documentário que é chocante: o Salazar escrevia os seus discursos para pessoas que ele sabia serem ignorantes. Ele falava contando sempre com a falta de educação do povo português. E esse continua a ser o mal de Portugal, as pessoas preocupam-se muito pouco com a educação (MIRANDA, 2010).

Além de defender a ideia de que a baixa qualidade da educação no país continua a ser um problema a ser enfrentado, o cineasta também aborda a questão do legado salazarista presente ainda nos dias atuais, percebido por alguns olhares analíticos. Muitos dos valores e mitos disseminados durante os anos de regime estão inerentemente ligados à sociedade portuguesa contemporânea, uma vez que não foram reelaborados.

Eduardo Lourenço, em "Da literatura como interpretação de Portugal” (2015), ensaio resultante da "Conferência realizada na Fundação Gulbenkian, em 5 de Fevereiro de 1975, no âmbito do curso sobre 'Modernismo' promovido pela Universidade Nova de Lisboa" (LOURENÇO, 2015, p. 80), isto é, menos de um ano após a queda do regime, asseverou que

As contas a ajustar com as imagens que a nossa aventura colonizadora suscitou na consciência nacional são largas e de trama complexa de mais [...]. Ao menos uma vez na nossa existência multissecular aproveitemos a dolorosa lição de uma cegueira que se quis inspiração divina e patriótica, para nos compreendermos em termos realistas, inventando uma relação com Portugal na qual nos possamos rever sem ressentimentos fúnebres, nem delírios patológicos (LOURENÇO, 2015, p. 116). 
O intelectual fala da necessidade da prestação de contas com o passado, então recente, de forma realista e equilibrada. Entretanto, já próximo da virada do século XX para o XXI, Lourenço (1999) critica o silêncio gerado ao redor da figura de Salazar, uma vez que a leitura crítica de seu governo ainda estava por ser feita:

A cultura política pós-25 de abril achou melhor pô-lo [Salazar] fora da História. Com raras exceções, até tempos recentes em que mais importam as suas manias privadas de viúvo casado do que a sua política, o seu esqueleto jaz no armário mais esquecido de uma História como a nossa feita mais de memória renovada e revisitada do que de sucessivas camadas de esquecimento. É paupérrima a literatura sobre Salazar, quer memorial, quer ideológica, política, econômica, financeira e cultural (LOURENÇO, 1999, p. 139).

O filósofo faz uma espécie de balanço do que tinham sido, até então, aquele quartel de século após a Revolução dos Cravos e constata que uma reflexão aprofundada ainda estava por se fazer:

[...] o Estado Novo e seu chefe, não sem motivos, são julgados à luz de um desastre final que continua sem leitura, no passado e no presente. Um desastre que ninguém quis, na época, endossar, e que lido às avessas se converteu no ato fundador da Nova Democracia portuguesa. Como não se podia evocar um, não se podia revisitar o outro. Há quase um quarto de século que vivemos num regime sem nome. Em função dele é impossível, no sentido em que o foi durante séculos [...], aperceber neste momento [...], qual seja o destino de Portugal. Ou, mais fundamente, o que é, ainda, Portugal como destino (LOURENÇO, 1999, p. 139-140).

A observação do intelectual referente às "manias privadas de viúvo casado" de Salazar parece ter se conservado com o transcorrer do tempo. As leituras feitas a respeito da figura do ditador nos anos sucessivos acabaram sendo muito rasas. Em 2009 a rede de televisão SIC produziu a minissérie Salazar, a vida privada, transformada em longametragem e lançada em DVD no mesmo ano, tendo como realizador Jorge Queiroga. Em consonância com o título, o conteúdo mantém-se fiel à "vida privada" do ditador, sem se enveredar por aspectos políticos de seu governo. Na capa traseira do DVD encontramos:

A vida secreta de Salazar, oposto absoluto do pudor, isolamento e austeridade da vida pública. Afinal Salazar tinha uma vida secreta. Uma vida de paixões. [...] eram e continuam desconhecidas para o grande público as paixões que Salazar nutriu [...]. Este filme resulta do choque entre a narrativa propagandística, que a francesa Christine Garnier popularizou em livro, e as diferentes tramas amorosas protagonizadas pelas outras mulheres cujos corações foram atingidos pela flecha do Cupido de Santa Comba Dão. [...] "Salazar, A Vida Privada" mostra o que os portugueses nunca até hoje sonharam ver: Salazar tinha, afinal, uma turbulenta vida afectiva (SALAZAR, A VIDA PRIVADA, 2009).

O filme de Queiroga não propõe nenhuma reflexão crítica acerca da figura de Salazar, podendo ser classificado como ficção histórico-biográfica. Os aspectos mais 
significativos de seu governo são atenuados ou sequer mencionados, priorizando as supostas relações amorosas e sexuais do ditador.

Este tipo de produção acaba se tornando nociva para a população portuguesa em geral, pois contribui com o silenciamento a respeito do que foi o salazarismo. Dois anos antes, em 2007, Salazar fora eleito "o maior português de sempre", conforme informa o jornal Público:

Nem D. Afonso Henriques, nem D. João II, nem Camões, nem mesmo o Infante D. Henrique. António de Oliveira Salazar foi o nome escolhido pela maioria dos telespectadores da RTP1 que votaram na eleição do "maior português de sempre", no âmbito do programa "Os Grandes Portugueses" (PÚBLICO, 2007).

Muito embora se tratasse de um programa televisivo de entretenimento, o fato que chama a nossa atenção é que a eleição se deu por voto popular, ou seja, os telespectadores escolheram a figura de maior destaque dentro da historiografia portuguesa, de acordo com seu juízo, a partir de uma lista inicial com cem nomes. Salazar foi representado por $41 \%$ dos votos, seguido por Álvaro Cunhal, membro do Partido Comunista Português, com 19,1\%, e tendo, como terceiro colocado, o diplomata Aristides de Sousa Mendes, com $13 \%$ dos votos, famoso por ter salvo a vida de milhares de refugiados judeus durante a Segunda Guerra Mundial (PÚBLICO, 2007).

Com relação ao mundo virtual, vários são os sites que se dedicam a cultuar a imagem do ditador, como o portal Salazar, O Obreiro da Pátria, em plena atividade e bastante visitado. $\mathrm{Na}$ seção de esclarecimento da referida página, lê-se acerca do homenageado:

Um Homem que governa durante 40 anos ininterruptamente, que define uma época, que cria uma doutrina e que comanda os destinos de um país até à actualidade, teve que ter inspiração senão divina pelo menos superior.

É neste contexto que após colhidos os elementos possíveis sobre a vida e obra de um dos maiores Estadistas da História da Humanidade, os vou descrevendo com o rigor que me é possível e foi dado confirmar pela leitura atenta de algumas obras a que tive acesso nuns casos, e pelo testemunho pessoal noutros (SALAZAR, O OBREIRO DA PÁTRIA, 2018, grifos nossos).

Vemos, no excerto acima, a recuperação das narrativas criadas pelo Estado Novo, dada a opinião do mantenedor do site que atribui "inspiração divina/superior" a Salazar durante os quase quarenta anos que esteve à frente do governo português. Ademais, é necessário pontuar a ocorrência hiperbólica que define o político como "um dos maiores Estadistas da História da Humanidade”, ultrapassando a esfera de atuação portuguesa. 
Com base nos exemplos aqui mencionados, podemos constatar que a imagem de Salazar como um homem admirável e um grande líder persiste no imaginário popular de boa parte da população portuguesa ainda nos dias atuais. Inferimos que uma quota de responsabilidade na disseminação dessa ideia cabe aos meios de comunicação portugueses, que, segundo o filósofo José Gil, causam um desserviço à população:

\begin{abstract}
A televisão portuguesa é como toda gente sabe (e com raríssimas excepções, que toda gente também conhece) uma pura miséria, uma máquina de fabricação e sedimentação de iliteracia. E a rádio e a imprensa (sempre com as excepções que há em tudo) fecham constantemente as aberturas mínimas, as fendas e brechas por onde algum ar fresco, alguma força livre pudessem passar ainda (GIL, 2017, p. 31).
\end{abstract}

O ícone de um Salazar austero, mas paternal, responsável por ter colocado as finanças do país em ordem, por ter impedido que a guerra chegasse às terras portuguesas, e por nunca ter constituído família para se dedicar à nação, por exemplo, acabou sendo transferido para as gerações que eram crianças ou ainda não eram nascidas durante o salazarismo.

Notamos no Brasil um movimento análogo por parte de certas parcelas da população que pedem, por exemplo, a volta dos militares ao poder, ou seja, o retorno de uma ditadura militar, sem conhecer, de fato, o que esse isso significa. Concordamos com Canijo quando ele diz que a falta de uma educação de qualidade promove este tipo de atitude. Somente o pensamento crítico aliado a pesquisas sérias poderão fazer com que as pessoas venham a conhecer os erros cometidos no passado a fim de evitar que eles voltem a acontecer.

A relutância em querer encarar o passado sombrio de um governo antidemocrático parece ser uma característica comum entre várias nações depois das quedas desses regimes, e é o que sucede com Portugal. Carolin Overhoff Ferreira (2014) elucida que "É possível observar que após os processos de redemocratização, a maioria dos países com passado ditatorial costuma demorar ou evitar encarar as atrocidades cometidas pelo regime anterior" (FERREIRA, 2014, p. 265).

O filósofo José Gil (2017), mentor de Canijo durante o processo de criação de Fantasia Lusitana, assevera que

[...] o salazarismo foi uma doença que pôs de rastos o povo português. Doença do espírito (e dos corpos) e, enquanto tal, raramente tomada em consideração pelos historiadores e sociólogos da época. Hoje, celebra-se mesmo Salazar em biografias e fotobiografias de autores de «esquerda». Mais uma consequência lógica da não-inscrição (GIL, 2017, p. 23-24). 
Para Gil, a "não-inscrição" tem a ver com a não realização: "Nada acontece, quer dizer, nada se inscreve - na história ou na existência individual, na vida social ou no plano artístico" (GIL, 2017, p. 15). O intelectual afirma que

O 25 de Abril recusou-se, de um modo completamente diferente, a inscrever no real os 48 anos de autoritarismo salazarista. Não houve julgamento de Pides nem de responsáveis do antigo regime. Pelo contrário, um imenso perdão recobriu com um véu a realidade repressiva, castradora, humilhante de onde provínhamos. Como se a exaltação afirmativa da «Revolução» pudesse varrer, de uma penada, esse passado negro. Assim se obliterou das consciências e da vida a guerra colonial, as vexações, os crimes, a cultura do medo e da pequenez medíocre que o salazarismo engendrou. Mas não se constrói um «branco» (psíquico ou histórico), não se elimina o real e as forças que o produzem, sem que reapareçam aqui e ali, os mesmos ou outros estigmas que testemunham o que se quis apagar e que insiste em permanecer (GIL, 2017, p. 16).

O pensador parece esclarecer os motivos de ainda, nos dias de hoje, algumas camadas da população portuguesa enxergarem em Salazar um benfeitor da Pátria. Essas pessoas se alimentam de um certo saudosismo (do que viveram e do que não viveram) e projetam no salazarismo uma espécie de "paraíso perdido". A não inscrição, isto é, o não acontecer, pode ser interpretada como a falta de uma análise crítica, séria e madura acerca do período salazarista que ainda não parece ter sido suficientemente feita. Podemos dizer que o entusiasmo gerado após a queda do regime acabou por apagar todos os desmandos praticados durante a ditadura, mantendo, no consciente coletivo português, os ecos dos mitos veiculados pela propaganda.

De acordo com José Gil (2017),

o Portugal de hoje prolonga o antigo regime. A não-inscrição não data de agora, é um velho hábito que vem sobretudo da recusa imposta ao indivíduo de se inscrever. Porque inscrever implica acção, afirmação, decisão com as quais o indivíduo conquista autonomia e sentido para a sua existência. Foi o salazarismo que nos ensinou a irresponsabilidade - reduzindo-nos a crianças, crianças grandes, adultos infantilizados (GIL, 2017, p. 17).

A proximidade de João Canijo com José Gil permitiu que o cineasta percebesse, de maneira mais óbvia, a presença dos dois níveis de realidade em Fantasia Lusitana. É o que nos explica Vítor de Sousa (2013):

O filme integra as ideias de José Gil sobre o período do Estado Novo e lança um olhar centrado na questão da identidade nacional, sendo que a troca de perspetivas entre o realizador e o filósofo terá reforçado a ideia inicial do primeiro sobre a existência de dois níveis de realidade: o da propaganda (virtual), e o decorrente da guerra (real) (SOUSA, 2013, p. 623).

Se por um lado o Estado Novo utilizou o cinema em prol do regime, principalmente os filmes de atualidades, para veicular os seus valores à população e ocultar, de fato, o que acontecia, Canijo irá utilizar o mesmo material produzido pelos 
órgãos de propaganda daquela época para subverter aquela ordem. Segundo Gauthier, “Os filmes de montagem de atualidades [...] são uma ocasião de revisitar a história que pode se mostrar apaixonante, mas que revela mais o ponto de vista do autor do que a realidade da época" (GAUTHIER, 2011, p. 263). Em Fantasia Lusitana, Canijo não apenas revisita aquele período histórico do século XX em Portugal, mas vai além. Ele rearranja o material coletado, insere elementos que deliberadamente foram omitidos ou censurados pelo governo, como a presença de refugiados em Lisboa durante a guerra, e propõe uma nova leitura do período.

Além de inserir imagens desses estrangeiros, em sua maioria judeus que fugiam da perseguição nazista, Canijo dá voz a eles, permitindo que Döblin, Mann e SaintExupéry, mesmo depois de mortos, se expressem a respeito da realidade nos países ocupados e se espantem com o que encontram em Portugal, isto é, uma realidade conflitante com a experiência vivida por eles. A esse respeito, Ribas (2014a) explica que

Os textos dos escritores estrangeiros contradizem, de forma nítida, a fantasia do Portugal proposta por Salazar e as imagens que mandou fazer. Eles expõem a falsidade do mito do ditador que inventou um país grande, rico e neutro. A dura realidade de uma população analfabeta, pobre e com fome é sempre excluída pelas imagens que ilustram o discurso do regime. Mesmo as imagens dos refugiados são excluídas destas sequências de atualidades. Os discursos de Salazar elevam Portugal a uma das maiores nações do mundo, enquanto os textos das três personalidades notam as ilusões constantes desse discurso, caracterizando o contexto social que encontram de forma bastante crítica, como, por exemplo, a existência de analfabetos e de comportamentos rudes. (RIBAS, 2014a, p. 281).

Dessa forma, com Fantasia Lusitana, João Canijo logra propor uma releitura do Estado Novo, sobretudo no que concerne à desconstrução da propaganda salazarista, concitando uma nova forma de interpretar aquele período. Dentro deste aspecto, este documentário poderia ser classificado, de acordo com Carolin Overhoff Ferreira (2014), como um "filme indisciplinar", isto é, um

filme [que] "pensa" entre as disciplinas, ou seja, revela a construção de ficções
destas ao demonstrar uma perspectiva heterogénea do mundo. Aponta para
uma dimensão política que está intrinsecamente ligada com o seu dissenso
estética [sic] que possibilita o reposicionamento da percepção da realidade ao
estimular as qualidades cognitivas e sensíveis do espectador (FERREIRA,
2014, p. 267).

Em suma, o salazarismo é um tema que precisa ser revisitado e discutido seriamente na sociedade atual, dado o silenciamento ou a recusa de abordá-lo por parte de vários setores da população. Entendemos que o cinema é uma das ferramentas que podem ser utilizadas para promover essa discussão, e que, de fato, "a indisciplinaridade 
no cinema português está a participar ativamente da tarefa de mudar a mentalidade da não-inscrição" (FERREIRA, 2014, p. 274). Sendo assim, em Fantasia Lusitana, João Canijo consegue, sobretudo através da montagem, oferecer uma releitura crítica do período, inserindo, no mesmo filme, materiais contemporâneos entre si, mas que não necessariamente circularam nos mesmos espaços.

A desconstrução da propaganda salazarista também decorre quando se dá o contraponto com a visão dos três intelectuais estrangeiros. Dessa forma, ao mesclar elementos das duas camadas de realidade, transformando-os em um só objeto por meio de recortes e de sobreposição de sons e imagens nos momentos mais adequados, o cineasta gera significado e estimula a reflexão, o que denota a presença de uma camada autoral que permeia todo o filme. Assim, "o manto diáfano da fantasia", utilizado pela propaganda, é retirado e a "nudez forte da verdade" é exposta. 


\section{REFERÊNCIAS}

\section{Bibliográficas}

ALFERES, Franck Noël da Silva. Hinos e Marchas militares no Estado Novo (19331958). Contributo para a História da Música Militar na Propaganda do Estado Português. 2012. 179 f. (Mestrado em Didáctica da História) - Faculdade de Letras, Departamento de História, Universidade de Lisboa, Lisboa, Portugal, 2012.

BENJAMIN, Walter. Magia e Técnica, Arte e Política: Ensaios sobre Literatura e História da Cultura. São Paulo: Editora Brasiliense,1996. 253 p.

BRAGA, Ricardo. O Jornal Português (1938-1951): veículo de propaganda cinematográfica de um país nas margens da guerra. Revista Prisma, Porto, n. 1, p. 128 174, 2005.2 Disponível em <http://ojs.letras.up.pt/index.php/prismacom/article/view/2150>. Acesso em 31 mar. 2018. ISSN 1646-3153.

CAPELATO, Maria Helena Rolim. Multidões em Cena, Propaganda política no varguismo e no peronismo. São Paulo: Editora Unesp, 2009, $2^{a}$ edição.

EISENSTEIN, Sergei. A forma do filme. Rio de Janeiro: Jorge Zahar Ed., 2002a. 235 p. O sentido do filme. Rio de Janeiro: Jorge Zahar Ed., 2002b. 159 p.

FERREIRA, Carolin Overhoff. 48: Susana de Sousa Dias, Portugal/França (2009). In: FERREIRA, Carolin Overhoff (Org.). O Cinema Português através dos seus Filmes. Lisboa: Edições 70, 2014. p. 265-274.

FERRO, Marc. Cinema e História. Rio de Janeiro: Paz e Terra, 1992. 143p.

GAUTHIER, Guy. O documentário: Um outro cinema. Campinas: Papirus, 2011.

GIL, José. Portugal, Hoje: O Medo de Existir. Lisboa: Relógio d'Água Editores, 2017. $201 \mathrm{p}$.

GOMES, Sérgio Alexandre da R. As identidades nacionais nos regimes ditatoriais: o caso da romanità na Itália fascista e o reaportuguesamento salazarista. Revista da Faculdade de Letras - Ciências e Técnicas do Património, Porto, I Série vol. V-VI, p. 189-224, 2006-2007. Disponível em $<$ http://ler.letras.up.pt/site/default.aspx?qry=id04id110id2257\&sum=sim>. Acesso em 29 jul. 2016. ISSN 1645-4936.

GRANJA, Paulo Jorge. A comédia à portuguesa, ou a máquina de sonhos a preto e branco do Estado Novo. In: TORGAL, L. R. Coord. O cinema sob o olhar de Salazar. Coimbra: Círculo de Leitores e Temas e Debates, 2011. p. 194-233.

GUERRA, Susana. A batalha das imagens: Apropriações da ditadura no cinema português. Guavira Letras, Três Lagoas/MS, n. 20, p. 94-100, jan./jun. 2015.

LE GOFF, Jacques. Memória. In: História e Memória. Campinas: Editora Unicamp, 2003. P. 419-476.

LEVI, Primo. I sommersi e i salvati. Torino: Einaudi, 2017. 191p. 
LOURENÇO, Eduardo. Da literatura como interpretação de Portugal. In: O labirinto da saudade. Lisboa: Gradiva, 2015, p. 80-117. 10ª ed.

. Portugal como destino: dramaturgia cultural portuguesa. In: Mitologia da saudade: seguido de Portugal como destino. São Paulo: Companhia das Letras, 1999, p. 89-154.

MACEDO, Isabel; BASTOS, Rita; CABECINHAS, Rosa. Representações da ditadura portuguesa: as imagens de arquivo enquanto artefactos de memória em Fantasia Lusitana e 48. In: LOPES, Frederico; CUNHA, Paulo; PENAFRIA, Manuela (Orgs.). Cinema em português - VII jornadas. Beira: Universidade da Beira Interior. Editora LabCom.IFP, 2016. p. 31-58. ISBN: 978-989-654-268-9. Disponível em <http://www.labcomifp.ubi.pt/ficheiros/201604051439-

201602 flopespcunhampenafria_viicinemaportugues.pdf>. Acesso em 17 abr. 2018.

MARTINHO, Francisco Carlos Palomanes. O Pensamento Autoritário no Estado Novo português: algumas interpretações. Locus: revista de história, Juiz de Fora, v. 13, n. 2, p. 9-30, 2007. Disponível em: 〈https://locus.ufjf.emnuvens.com.br/locus/issue/view/114〉. Acesso em 29 jul. 2016. ISSN: 1413-3024.

MENDES, João Maria. Novas \& velhas tendências no cinema português contemporâneo. Amadora: Biblioteca da Escola Superior de Teatro e Cinema, 2010. 437p.

NICHOLS, Bill. Introdução ao documentário. Campinas: Editora Papirus, 2013. 270 p.

PAULO, Heloísa. Documentarismo e propaganda: as imagens e os sons do regime. In: TORGAL, Luís Reis. (Coord.). O cinema sob o olhar de Salazar. Coimbra: Círculo de Leitores e Temas e Debates, 2011. p. 93-116.

PEREIRA, Wagner Pinheiro. O império das imagens de Hitler: O projeto de expansão internacional do modelo de cinema nazi-fascista na Europa e América Latina (1933 1935). 439 p. Tese (Doutorado em História) - Departamento de História da Faculdade de Filosofia, Letras e Ciências Humanas, Universidade de São Paulo. São Paulo, 2008.

PITA, António Pedro. Temas e figuras do ensaísmo cinematográfico. In: TORGAL, Luís Reis (Coord.). O cinema sob o olhar de Salazar. Coimbra: Círculo de Leitores e Temas e Debates, 2011. p. 42-62.

QUEIRÓS, Eça de. A Relíquia. Rio de Janeiro: Nova Aguilar, 1997. 4v. 8.000 p.

RAIMUNDO, Filipa. Partidos Políticos e justiça de transição em Portugal: o caso da polícia política (1974-1976). In: PINTO, António Costa \& MARTINHO, Francisco Carlos Palomanes (orgs.). O passado que não passa: a sombra das ditaduras na Europa do Sul e na América Latina. $1^{\text {a }}$ ed. Rio de Janeiro: Civilização Brasileira, 2013, p. 75-126.

RIBAS, Daniel. Fantasia Lusitana: João Canijo, Portugal (2010). In: FERREIRA, Carolin Overhoff (Org.). O Cinema Português através dos seus Filmes. Lisboa: Edições 70, 2014a. p. 275-283.

Retratos de Família. A Identidade Nacional e a Violência em João Canijo. 2014. 360 f. Tese (Doutorado em Estudos Culturais) - Departamento de Línguas e Culturas, Universidade de Aveiro, Aveiro, Portugal, 2014b.

RODRIGUES, Ana Salgueiro. "Fantasia? Lusitana? Cinema, História(s de vida) e Ética Artística em Daniel Blaufuks e João Canijo”. In: Doc On-line, n. 09, pp. 60-79, 2010. 
Disponível em <http://www.doc.ubi.pt/09/doc09.pdf>. Acesso em 21 abr. 2018. ISSN: 1646-477X.

ROSAS, Fernando. Estado Novo, Império e Ideologia Imperial. In: Revista História das Ideias, Vol.17, pp.19-32, 1995.

O salazarismo e o homem novo: ensaio sobre o Estado Novo e a questão do totalitarismo. Análise Social. Lisboa, v. XXXV, p. 1.031-1.054, 2001.

SÁ, Sérgio Miguel Lobo da Conceição Bordalo e. Trunfos e contradições da vontade: para uma releitura de Lopes Ribeiro e Leitão de Barros no contexto do cinema de propaganda. 2013. 542 f. Tese (Doutorado em Estudos Artísticos - Estudos do Cinema e Audiovisual) - Faculdade de Letras, Universidade de Lisboa, Lisboa, Portugal, 2013.

SALMI, Stefano e POLI, Davide. A cultura da vigilância: aspectos significantes na Itália e Portugal entre as duas guerras mundiais In: CARNEIRO, Maria Luiza Tucci; CROCI, Federico (Orgs.). Tempos de Fascismos: Ideologia - Intolerância - Imaginário. São Paulo: Editora da Universidade de São Paulo, Imprensa Oficial, Arquivo Público do Estado de São Paulo, 2010. p. 372-383.

SANTOS, Boaventura de Sousa. Entre Próspero e Caliban: colonialismo, póscolonialismo e interidentidade. Novos Estudos Cebrap, São Paulo, e. 66, v. 2, p. 23-52, jul. 2003.

SARAMAGO, José. $O$ ano da morte de Ricardo Reis. São Paulo: Companhia das Letras, 1994. $415 \mathrm{p}$.

SONTAG, Susan. Sobre Fotografia [recurso eletrônico]. São Paulo: Companhia das Letras, 2004.

SOUSA, Vítor de. Da 'portugalidade' à lusofonia. Vila Nova de Famalicão: Edições Húmus, 2017. 424 p.

. "Fantasia Lusitana", de João Canijo: O Portugal Ficcional vs. O País real. O Estado Novo e a 'Portugalidade'. A Construção da Identidade. In: VALENTE, António Costa e CAPUCHO, Rita (Coords.). Avanca I Cinema 2013. Avanca: Edições Cine-Clube de Avanca, 2013, p. 623-630. ISBN: 978-989-96858-3-3.

TADEU, Tiago Agostinho Arrifano. A Guarda durante a II Guerra Mundial. 2011. 190 f. Dissertação (Mestrado em História Econômica e Social Contemporânea) - Faculdade de Letras, Universidade de Coimbra, Coimbra, Portugal, 2011.

TORGAL, Luís Reis. O cinema sob o olhar de Salazar. Coimbra: Círculo de Leitores e Temas e Debates, 2011.

Estado Novo e Intolerâncias: Repressão e Reprodução Ideológica. In: CARNEIRO, Maria Luiza Tucci; CROCI, Federico (Orgs). Tempos de Fascismos: Ideologia - Intolerância - Imaginário. São Paulo: Editora da Universidade de São Paulo, Imprensa Oficial, Arquivo Público do Estado de São Paulo, 2010. p. 105-140.

VANOYE, Francis e GOLIOT-LÉTÉ, Anne. Ensaio sobre a análise fílmica. Campinas: Papirus Editora, 2014. 143 p.

XAVIER, Ismail. Cinema: revelação e engano. In: $O$ olhar e a cena: Melodrama, Hollywood, Cinema Novo, Nelson Rodrigues. São Paulo: Cosac \& Naify, 2003. p. 31-57. 
O discurso cinematográfico - a opacidade e a transparência. São Paulo: Paz e Terra, 2005.

\section{Audiovisuais}

FANTASIA lusitana. Direção de João Canijo. Produção de João Trabulo. Realização de João Canijo. Montagem de João Braz. Intérpretes: Hanna Schygulla, Rüdiger Vogler, Christian Patey. Roteiro: João Canijo. Música: Pedro Góis. Lisboa: Periferia Filmes, 2010. on-line (67 min.), son., pb. Legendado. Disponível em: <https://www.youtube.com/watch?v=cAtTwRnjXyQ>. Acesso em 01 dez. 2017.

MOCIDADE vitoriosa. Realização da Secção de Cinema do SPN. Direção de fotografia de Octávio Bobone. Som de Francisco Quintela. Portugal, 1939. on-line (33 min.), 35 mm, pb. Disponível em: http://www.cinemateca.pt/CinematecaDigital/Ficha.aspx?obraid=3488\&type=Video. Acesso em 12 out. 2017.

O PÁTIO das cantigas. Realização de Francisco Ribeiro. Produção de António Lopes Ribeiro. Música de Frederico de Freitas. Intérpretes: Maria das Neves, Vasco Santana, António Silva, Ribeirinho, Laura Alves, Barroso Lopes et al. Argumento e diálogos de António Lopes Ribeiro, Vasco Santana e Francisco Ribeiro. Portugal, 1942. on-line (105 min.), pb. Disponível em 〈https://www.youtube.com/watch? v=KqzCaY7yGeQ>. Acesso em 12 maio 2018.

SALAZAR, a vida privada. Realização de Jorge Queiroga. Produção de Manuel S. Fonseca e VC Filmes. Coprodução da SIC. Música de Bruno Bizarro. Fotografia de Orlando Alegria. Intérpretes: Diogo Morgado, Soraia Chaves, Benedita Pereira, Cláudia Vieira, Fernanda Borsatti, Filipe Vargas et al. Argumento de António Costa Santos e Pedro Marta Santos. 2009, DVD (110 min.), son., cor.

\section{Outras fontes}

CÂMARA, Vasco. João Canijo: “Acho que isto não tem cura”. In: Ípsilon (suplemento do jornal Público de 22 de abril de 2010). Disponível em <https://www.publico.pt/2010/04/22/culturaipsilon/noticia/joao-canijo-acho-que-istonao-tem-cura-255087>. Acesso em 05 nov. 2016.

CARVALHO, Ana Margarida de. Encontro imediático com João Canijo: Fantasia Lusitana -Ó Males sem Remédio Parte 2. In: Cinema (suplemento do portal de conteúdo Visão de 22 de abril de 2010). Disponível em <http://visao.sapo.pt/cinema/encontroimediatico-com-joao-canijo-fantasia-lusitana-o-males-sem-remedio-parte-2=f556164>.

Acesso em 08 abr. 2018.

FERREIRA, Francisco. "Salazar como você nunca o ouviu". In: IndieLisboa 2010 (suplemento do jornal Expresso de 22 de abril de 2010). Disponível em <http://expresso.sapo.pt/dossies/dossiest_cultura/Postal_indieLisboa2010/salazar-comovoce-nunca-o-ouviu=f578162>. Acesso em 13 ago. 2017.

FURTADO, Filipe. Fantasia Lusitana, de João Canijo (Portugal, 2010). In: Olhares (seção da revista Cinética, Cinema e Crítica de setembro de 2012). Disponível em <http://www.revistacinetica.com.br/fantasialusitana.htm>. Acesso em 01 nov. 2016. 
HALPERN, Manuel. Fantasia Lusitana: Lisboa, porto de (des)abrigo. In: Estado Crítico (suplemento do portal de conteúdo Visão de 29 de abril de 2010). Disponível em <http://visao.sapo.pt/cinema/estadocritcio/fantasia-lusitana-lisboa-porto-dedesabrigo=f556079>. Acesso em 08 abr. 2018.

LUSA. João Canijo em "Fantasia Lusitana" dia 22. In: Cartaz (suplemento do jornal DN - Diário de Notícias de 20 de abril de 2010). Disponível em <https://www.dn.pt/cartaz/cinema/interior/joao-canijo-em-fantasia-lusitana-dia-22$\underline{1548910 . h t m l}>$. Acesso em 01 nov. 2016.

MENDONÇA, Diana. Fantasia Lusitana. In: Geração C (programa do Canal Cascais, da Câmara Municipal de Cascais no YouTube, publicado em 11 de outubro de 2010). Disponível em <https://www.youtube.com/watch?v=si1cx6pAeBM>. Acesso em 29 abr. 2018.

MIRANDA, Luís Leal. "Por cá as coisas passam e desaparecem sem deixar marca". In: Fantasia Lusitana traz-nos de volta aos anos 40, texto publicado em 28 de abril de 2010 em Aterrem em Portugal (blog de GUERREIRO, Carlos, que divulgou a entrevista de Miranda a Canijo efetuado em 22 de abril de 2010 no jornal "i”, que não está mais online). Disponível em <http://aterrememportugal.blogspot.com.br/2010/04/fantasialusitana-traz-nos-de-volta-os.html >. Acesso em 08 abr. 2018.

MONTEIRO, Inês. Trabalho de realizador. In: Rua de Baixo $\left(\mathrm{RDB}^{\mathrm{TM}}\right.$ - revista on-line sobre Cultura e Lifestyle de 06 de outubro de 2011). Disponível em <http://www.ruadebaixo.com/joao-canijo.html >. Acesso em 13 ago. 2017.

MOURINHA, Jorge. "Fantasia Lusitana": tudo pela nação. In: Ípsilon (suplemento do jornal Público de 22 de abril de 2010). Disponível em: $<$ https://www.publico.pt/2010/04/22/culturaipsilon/noticia/quotfantasia-lusitanaquottudo-pela-nacao-255124>. Acesso em 08 abr. 2018.

OLIVEIRA, Luís Miguel. A guerra de um país só. In: Ípsilon (suplemento do jornal Público de 29 de abril de 2010). Disponível em <https://www.publico.pt/2010/04/29/culturaipsilon/critica/a-guerra-de-um-pais-so-

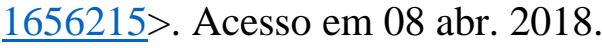

PINTO, João. Crítica - Fantasia Lusitana (2010). In: Portal Cinema (blog dedicado ao cinema, publicado em 04 de maio de 2010). Disponível em <http://www.portalcinema.com/2010/05/critica-fantasia-lusitana-2010.html>. Acesso em 08 abr. 2018.

PÚBLICO, Jornal on-line. "Os Grandes Portugueses" - Salazar eleito "o maior português de sempre” em programa da RTP. In: Público de 26 de março de 2007. Disponível em <https://www.publico.pt/2007/03/26/portugal/noticia/salazar-eleito-o-maior-portuguesde-sempre-em-programa-da-rtp-1289390>. Acesso em 05 maio 2018.

SALAZAR, O Obreiro da Pátria. Página dedicada à vida e obra de António de Oliveira Salazar. Disponível em 〈http://oliveirasalazar.org/default.asp〉. Acesso em 05 maio 2018.

SANTOS, Rogério. João Canijo e a sua (nossa) fantasia lusitana. In: Indústrias Culturais (blog que aborda reflexões sobre indústria culturais, publicado em 02 de maio de 2010). Disponível em <https://industrias-culturais.hypotheses.org/7924>. Acesso em 08 abr. 2018. 